\title{
Gezond verstand
}

Evidence-based preventie van psychische stoornissen

S.A. Meijer, F. Smit, C.G. Schoemaker, P. Cuijpers

\section{Trimbos}

Dit VTV-Themarapport is een gezamenlijk product van RIVM en Trimbos-instituut, in opdracht van het Ministerie van Volksgezondheid, Welzijn en Sport. 
Een publicatie van het

Rijksinstituut voor Volksgezondheid en Milieu

Postbus 1

3720 BA Bilthoven

Auteursrecht voorbehouden

(c) 2006, Rijksinstituut voor Volksgezondheid en Milieu, Bilthoven

Aan de totstandkoming van deze uitgave is de uiterste zorg besteed. Voor informatie die nochtans onvolledig of onjuist is opgenomen, aanvaarden redactie, auteurs en uitgever geen aansprakelijkheid. Voor eventuele verbeteringen van de opgenomen gegevens houden zij zich gaarne aanbevolen. Alle rechten voorbehouden. Niets uit deze uitgave mag worden verveelvoudigd, opgeslagen in een geautomatiseerd gegevensbestand of openbaar gemaakt in enige vorm of op enige wijze, hetzij elektronisch, mechanisch, door fotokopieën, opnamen of enige andere manier, zonder voorafgaande schriftelijke toestemming van het RIVM en de uitgever. Voorzover het maken van kopieën uit deze uitgave is toegestaan op grond van artikel 16b Au-teurswet 1912 juncto het Besluit van 20 juni 1974, Stb. 351, zoals gewijzigd bij het Besluit van 23 augustus 1985, Stb. 471, en artikel 17 Auteurswet 1912, dient men de daarvoor wettelijk verschuldigde vergoedingen te voldoen aan de Stichting Reprorecht, Postbus 882, 1180 AW Amstelveen. Voor het overnemen van gedeelten uit deze uitgave in bloemlezingen, readers en andere compilatiewerken (artikel 16 Auteurswet 1912) dient men zich tot de uitgever te wenden.

RIVM-rapportnummer: 270672001

ISBN-10: 90-6960-165-6

ISBN-13: 978-90-6960-165-6 


\section{Voorwoord}

De preventie van psychische stoornissen is beleidsmatig een vrij nieuw onderwerp. Tot voor enkele jaren werd er in beleidsnota's nog weinig aandacht aan besteed. Dat is inmiddels veranderd: in de nieuwste Preventienota zijn zowel depressie als schadelijk alcoholgebruik opgenomen als speerpunt van beleid.

Er zijn twee duidelijke oorzaken voor deze recente beleidsaandacht aan te wijzen. Allereerst hebben de Volksgezondheid Toekomst Verkenningen van 2002 en 2006 duidelijk gemaakt dat psychische stoornissen veel voorkomen en leiden tot veel ziektelast. Van de tien ziekten met de hoogste ziektelast, zijn er volgens het RIVM vier psychisch van aard. Daarnaast is er, mede gestimuleerd door ZonMw, de laatste jaren veel onderzoek gedaan naar het effect van preventieve interventies. Uit deze onderzoeken, voornamelijk uitgevoerd door het Trimbos-instituut, blijkt dat het inderdaad mogelijk is om het ontstaan van psychische stoornissen te voorkomen.

Voor u ligt het rapport 'Gezond verstand. Evidence-based preventie van psychische stoornissen'. In het rapport hebben onderzoekers van het RIVM en het Trimbos-instituut hun kennis gebundeld. Daardoor is er nu voor het eerst een samenhangend overzicht ontstaan over de epidemiologie, de gezondheidseconomie en het effectonderzoek. Dit overzicht en de daaruit voortvloeiende beleidsaanbevelingen maken het zeer relevant voor beleidsmakers.

Voor wie bij GGZ-preventie nog altijd vooral denkt aan goede bedoelingen is dit rapport een 'eye-opener'. Het veld wordt de laatste jaren in sneltreinvaart voorzien van een wetenschappelijke basis, zo blijkt. Ik hoop dat dit rapport ertoe leidt dat de preventiepraktijk verder vorm krijgt, en dat men in staat zal zijn meer mensen te bereiken. Want alleen op die manier zal het mogelijk zijn de enorme ziektelast veroorzaakt door psychische stoornissen met preventie te verminderen.

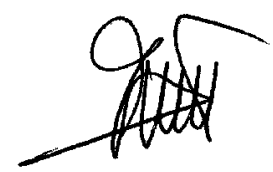

Ir. Hans de Goeij

Directeur-generaal van de Volksgezondheid

Ministerie van Volksgezondheid, Welzijn en Sport 



\section{Inhoudsopgave}

Voorwoord

Kernboodschappen

$1 \quad$ Inleiding en doel van het rapport $\quad 15$

$\begin{array}{lll}1.1 & \text { Aanleiding en achtergrond } & 15\end{array}$

$\begin{array}{ll}1.2 & \text { Waarom is preventie van psychische stoornissen belangrijk? }\end{array}$

$\begin{array}{lll}1.3 & \text { Effectieve preventie van psychische stoornissen } & 19\end{array}$

$\begin{array}{ll}1.4 & \text { Inhoud en leeswijzer } \\ \end{array}$

$2 \quad$ Vraagstelling en methode $\quad 21$

$\begin{array}{lll}2.1 & \text { Definitie en afbakening psychische stoornissen } & 21\end{array}$

2.2 Omvang, ernst en gevolgen op bevolkingsniveau 22

2.3 Kenmerken van de aangeboden preventieve interventies 23

2.4 Gezondheidseffecten van preventieve interventies $\begin{array}{ll}\text { op individueel niveau } & 27\end{array}$

2.5 Gezondheidswinst van preventieve interventies op bevolkingsniveau $\quad 30$

$3 \quad$ Preventie van depressie 33

3.1 Definitie, beloop en doelgroepen voor preventie 33

3.2 Omvang, ernst en gevolgen van depressie 36

3.3 Preventieve interventies voor depressie bij jongeren 40

3.3.1 In Nederland beschikbare interventies ter preventie van depressie bij jongeren $\quad 40$

3.3.2 Gezondheidseffecten van preventie van depressie bij jongeren $\quad 42$

3.4 Preventieve interventies voor depressie bij volwassenen 46

3.4.1 In Nederland beschikbare interventies ter preventie van depressie bij volwassenen $\quad 46$

3.4.2 Gezondheidseffecten van preventie van depressie bij volwassenen 49

3.5 Preventieve interventies voor depressie bij ouderen 53

3.5.1 In Nederland beschikbare interventies ter preventie van depressie bij ouderen 54

3.5.2 Gezondheidseffecten van preventie van depressie bij ouderen 57

3.6 Samenvatting en conclusies preventie depressie 59 
$4 \quad$ Preventie van angststoornissen

65

4.1 Definitie, beloop en doelgroepen voor preventie 65

$\begin{array}{lll}4.2 & \text { Omvang, ernst en gevolgen van angststoornissen } & 69\end{array}$

$\begin{array}{lll}4.3 & \text { Preventieve interventies voor angststoornissen bij jongeren } & 74\end{array}$

4.3.1 In Nederland beschikbare interventies ter preventie van angststoornissen bij jongeren $\quad 74$

4.3.2 Gezondheidseffecten van preventie van angststoornissen bij jongeren

4.4 Preventieve interventies voor angststoornissen bij volwassenen en ouderen

4.4.1 In Nederland beschikbare interventies ter preventie van angststoornissen bij volwassenen en ouderen

4.4.2 Gezondheidseffecten van preventie van angststoornissen bij volwassenen en ouderen

4.5 Samenvatting en conclusies preventie angststoornissen

$5 \quad$ Preventie van alcoholmisbruik en -afhankelijkheid

5.1 Definitie, beloop en doelgroepen voor preventie 93

5.2 Omvang, ernst en gevolgen van alcoholmisbruik en -afhankelijkheid 96

5.3 Overheidsmaatregelen ter preventie van alcoholmisbruik en -afhankelijkheid

5.3.1 Overheidsmaatregelen ter preventie van alcoholmisbruik en -afhankelijkheid

5.3.2 Gezondheidseffecten van overheidsmaatregelen ter preventie van alcoholmisbruik en -afhankelijkheid

5.4 Preventieve interventies voor alcoholmisbruik en -afhankelijkheid bij jongeren

5.4.1 In Nederland beschikbare interventies ter preventie van alcoholmisbruik en -afhankelijkheid bij jongeren

5.4.2 Gezondheidseffecten van preventie van alcoholmisbruik en -afhankelijkheid bij jongeren

5.5 Preventieve interventies voor alcoholmisbruik en -afhankelijkheid bij volwassenen en ouderen

5.5.1 In Nederland beschikbare interventies ter preventie van alcoholmisbruik en -afhankelijkheid bij volwassenen en ouderen

5.5.2 Gezondheidseffecten van preventie van alcoholmisbruik en -afhankelijkheid bij volwassenen en ouderen

5.6 Samenvatting en conclusies preventie alcoholmisbruik en -afhankelijkheid 
6 Overzicht resultaten en beschouwing

119

6.1 Consequenties van de methodologische uitgangspunten

6.2 Preventie voorkomt het ontstaan van psychische stoornissen

122

6.3 Gevaar van medicalisering van alledaags leed?

125

6.4 Geringe bereik van preventie belangrijkste knelpunt

7 Organisatorische context en beleidsaanbevelingen

129

7.1 Inleiding

129

7.2 Organisatorische en beleidsmatige context

129

7.2.1 Preventie van psychische stoornissen binnen de gezondheidszorg

130

7.2.2 Wettelijke kaders en financiering

132

7.2.3 Beleidsgeschiedenis preventie van psychische stoornissen

135

7.2.4 Conclusie

136

7.3 Verankeren van preventie in landelijk beleid

136

7.4 Verankeren van preventie in gemeentelijk beleid

137

7.5 Verankeren van preventie in de gezondheidszorg

140

\section{Literatuur}

\section{Bijlagen}

1 Medewerkers, Beleids Advies Groep, Wetenschappelijke Advies Commissie 159

2 Achtergronden bij de methode

3 Interventies gericht op de preventie van depressie

4 Interventies gericht op de preventie van angststoornissen

5 Interventies gericht op de preventie van alcoholmisbruik en -afhankelijkheid

6 Economische effecten van preventie

7 Beleidsgeschiedenis preventie van psychische stoornissen 209

8 Organisatorische context van preventie van psychische stoornissen $\quad 217$

9 Gebruikte afkortingen 



\section{Kernboodschappen}

\section{Preventie van psychische stoornissen in kansrijke positie}

\section{Psychische stoornissen vormen een belangrijk gezondheidsprobleem}

Depressie, angststoornissen en alcoholmisbruik en -afhankelijkheid komen veel voor: jaarlijks lijdt één op de vijf mensen in Nederland aan een van deze stoornissen. Ze komen niet alleen veel voor, maar leggen ook aanzienlijke beperkingen op aan het functioneren: ze behoren alle drie tot de top 10 van ziekten met de grootste ziektelast. Ook als het gaat om zorgkosten scoren psychische stoornissen hoog: zo kost de zorg voor depressie jaarlijks bijna 700 miljoen euro. Ziekteverzuim en arbeidsongeschiktheid als gevolg van psychische klachten zijn omvangrijk: één op de drie arbeidsongeschikten kan niet werken vanwege psychische stoornissen. Ook dat leidt jaarlijks tot hoge kosten.

\section{Naast behandeling is preventie nodig}

De geestelijke gezondheidszorg (GGZ) beschikt over effectieve behandelingen van de genoemde stoornissen. Toch lukt het maar heel gedeeltelijk de ziektelast op populatieniveau te verminderen. De oorzaak is dat maar een deel van de mensen met een stoornis wordt bereikt. Vervolgens ontvangen deze mensen niet altijd een bewezen effectieve behandeling. Ook volgen ze de ontvangen behandeling niet altijd even trouw. Zelfs onder de meest optimale omstandigheden kan de ziektelast door behandeling met maximaal $40 \%$ verminderd worden. Dit pleit er voor om naast behandeling ook preventie aan te bieden, om zo de ziektelast nog verder terug te dringen. Daarbij heeft het voorkómen van psychische stoornissen, als dat mogelijk is, uiteraard de voorkeur boven het behandelen als de stoornis al ontstaan is.

\section{Preventie van psychische stoornissen nu ook wetenschappelijk onderbouwd}

Preventie van psychische stoornissen is lang een gebied geweest waar goede bedoelingen de boventoon voerden. Dit terrein is de laatste jaren echter sterk aan het professionaliseren en verwetenschappelijken. Het aantal kwalitatief goede effectonderzoeken groeit gestaag. Dit rapport zet een groot aantal onderzoeken op het gebied van preventie van depressie, schadelijk alcoholgebruik en angststoornissen op een rij. Daaruit komt naar voren dat er nu voldoende bewijs is om bepaalde preventieve interventies op grotere schaal toe te passen. Er is preventief veel meer mogelijk dan een aantal jaren geleden.

\section{Preventie op de glijdende schaal tussen gezond en ziek}

De doelgroepen voor preventieve interventies bevinden zich op een continuüm tussen gezond en ziek. Universele preventie richt zich met voorlichting op gezonde mensen, selectieve preventie richt zich op mensen met een verhoogd risico (zoals kinderen van ouders met psychische stoornissen) en geïndiceerde preventie is bedoeld voor mensen met beginnende klachten, die echter (nog) niet beantwoorden aan de officiële diagnose voor een psychische stoornis. Terugvalpreventie - het voorkomen van de terugkeer van een stoornis na afloop van behandeling - valt buiten het bestek van dit rapport. 


\section{Preventie reduceert de kans op het ontstaan van psychische stoornissen}

Preventie van depressie werkt, maar bereikt onvoldoende mensen

Het is daadwerkelijk mogelijk om met preventieve interventies te voorkomen dat mensen met beginnende klachten een echte depressie ontwikkelen. Voorbeeld is de cursus 'In de put, uit de put', die wordt aangeboden als groepscursus en als individuele zelfhulpcursus met minimale begeleiding. Deze interventies zijn over het algemeen niet duur, terwijl de stoornissen die ze helpen te voorkomen met omvangrijke kosten gepaard gaan. Daarom zijn dergelijke preventieve interventies waarschijnlijk ook nog eens kosteneffectief. Het belangrijkste knelpunt is op dit moment het geringe bereik van dergelijke interventies. Zo wordt met depressiepreventie jaarlijks ongeveer vierduizend mensen bereikt. Dat is slechts 1\% van de ruim 350 duizend mensen die per jaar een depressie ontwikkelen. Wil depressie-preventie dus impact hebben op de volksgezondheid, dan moet gewerkt worden aan grootschalige implementatie.

\section{Overheidsmaatregelen voorkomen schadelijk alcoholgebruik, ruimte voor verbetering} Bepaalde overheidsmaatregelen blijken effectief te zijn in het terugdringen van schadelijk alcoholgebruik. In het buitenland bewezen effectieve overheidsmaatregelen zijn: accijnsverhoging, beperking van de winkelverkoop van alcohol in het weekend, het verbieden van alcoholreclame en onaangekondigde alcoholcontroles bij automobilisten. In Nederland heeft de landelijke overheid al een deel van deze maatregelen ingezet, maar hier is nog ruimte voor verbetering en aanscherping.

\section{Geïndiceerde interventies verminderen schadelijk alcoholgebruik}

Voor het terugdringen van schadelijk alcoholgebruik bij volwassenen zijn effectieve geïndiceerde interventies beschikbaar via internet: bijvoorbeeld de cursus 'Minder drinken' en de 'Drinktest'. Dankzij deze interventies gaan deelnemers minder drinken, waardoor hun drinkgedrag niet langer afwijkt van de richtlijn voor minder riskant alcoholgebruik. Daarmee zullen dit soort interventies ook helpen voorkomen dat er nieuwe gevallen ontstaan van alcoholmisbruik en -afhankelijkheid. Een bijkomend voordeel van interventies die via het internet worden aangeboden is hun grote bereik en de lage kosten. Jongeren vormen een belangrijke doelgroep voor alcoholpreventie. In verhouding tot hun leeftijdsgenoten in andere landen drinken Nederlandse jongeren op te jonge leeftijd en te veel. Er bestaat in ons land een uitgebreid aanbod van universele preventie gericht op jongeren, zoals het lesprogramma 'De gezonde school en genotmiddelen'. Opvallend is het ontbreken van een geïndiceerd aanbod voor jongeren. Inmiddels zijn op dit gebied enkele initiatieven opgezet, waarbij de ouders een belangrijke rol toebedeeld krijgen.

\section{Meer onderzoek nodig naar effectieve preventie van angststoornissen}

Terwijl er veel bekend is over de effectiviteit van depressiepreventie is er erg weinig bekend over de effectiviteit van preventieve interventies voor angststoornissen. Deze achterstand is opvallend, omdat het aantal mensen met angststoornissen groter is dan dat van depressie, en de ziektelast van bepaalde angststoornissen die van depressie ten minste evenaart. Op dit moment is het te vroeg voor een breed landelijk implementatie- 
plan voor de preventie van angststoornissen. Het is nu vooral van belang om de effectiviteit van preventie van angststoornissen hoog op de onderzoeksagenda te zetten. Paniekstoornis en sociale fobie verdienen daarbij in het bijzonder de aandacht: beide stoornissen komen veel voor en gaan gepaard met een aanzienlijke ziektelast.

Een drieslag voor de versterking van de preventie van psychische stoornissen

Het verhogen van het bereik van preventieve interventies voor psychische stoornissen is noodzakelijk. Dit vraagt om beleid op drie fronten: versterking van het landelijk beleid, ondersteuning van gemeentelijk beleid en opname van preventie van psychische stoornissen als vast onderdeel in de gezondheidszorg. Dit wordt hieronder concreet uitgewerkt, vooral aan de hand van de preventie van depressie. Voor depressie bestaat zoals gezegd een geïndiceerd preventief aanbod waarvan de effectiviteit is aangetoond, maar dat nog onvoldoende mensen bereikt om ook op bevolkingsniveau effect te sorteren. De onderstaande beleidsaanbevelingen om het bereik van deze interventies te verhogen zijn echter niet specifiek voor depressie; ze gelden grotendeels ook voor de preventie van schadelijk alcoholgebruik en angststoornissen.

\section{Preventie van psychische stoornissen als speerpunt van landelijk beleid}

Depressie en schadelijk alcoholgebruik als speerpunt in nieuwe preventienota

In de landelijke preventienota ‘Kiezen voor gezond leven' die het Ministerie van VWS in oktober 2006 uitbracht, hebben preventie van depressie en schadelijk alcoholgebruik de positie van speerpunt van beleid gekregen. Schadelijk alcoholgebruik had die positie al, voor depressie is dit nu de eerste keer. De informatie uit dit themarapport onderstreept het belang van deze positie. Het is immers mogelijk om met preventieve interventies de ziektelast als gevolg van deze psychische stoornissen te verminderen, de kwaliteit van leven van vele mensen te handhaven, en dat alles op een vermoedelijk kosteneffectieve manier. De voornemens uit de Preventienota worden nog geconcretiseerd in een landelijk actieplan.

\section{Gerichte publieksvoorlichting over preventie psychische stoornissen}

Om de ziektelast op bevolkingsniveau werkelijk te verminderen, zou het aantal deelnemers aan de effectief gebleken interventies flink omhoog moeten. De landelijke overheid kan bijdragen aan een groter bereik van selectieve en geïndiceerde preventie door het gericht inzetten van publieksvoorlichting over psychische stoornissen. Deze vorm van universele preventie kan helpen om in brede bevolkingslagen meer kennis en begrip te genereren ten aanzien van psychische stoornissen, wat mensen er zelf aan kunnen doen en bij wie zij terecht kunnen voor verdere hulp wanneer dat nodig mocht zijn. Daarmee kan het de stap naar een meer gerichte vorm van preventie vergemakkelijken.

\section{Bereik vergroten door randvoorwaarden te verbeteren}

Een goede verankering van preventie in zowel het gemeentelijk beleid als in de gezondheidszorg is een noodzakelijke randvoorwaarde voor brede implementatie van preventieve interventies. Gemeenten zijn meer gericht op universele interventies, de gezondheidszorg is vooral gericht op individuele behandeling van mensen die al een psychische 
stoornis hebben. Geïndiceerde en selectieve interventies vormen een tussengebied waarop beide partijen actief moeten zijn. Beide deelterreinen hebben hun eigen wettelijke en financiële kaders - de Wet Collectieve Preventie Volksgezondheid, de Wet Maatschappelijke Ondersteuning en de Zorgverzekeringswet - en sluiten in de praktijk nog niet goed op elkaar aan. Verbetering in die aansluiting is nodig voor de verankering van een samenhangend preventieaanbod.

\section{Psychische stoornissen opnemen in gemeentelijk gezondheidsbeleid}

\section{Preventie psychische stoornissen aanbieden binnen de nulde lijn}

Preventie zou zo dicht mogelijk bij de burger moeten worden aangeboden. Daarom zal ook preventie van psychische stoornissen meer dan voorheen onderdeel moeten worden van de voorzieningen die dicht bij de burger staan, met een lage toegangsdrempel. Ook zal vooral geïndiceerde preventie van psychische stoornissen een grotere plek moeten krijgen in settings buiten de gezondheidszorg, zoals scholen, werk en wijken. Daarbij kan gebruik worden gemaakt van de bestaande expertise in de tweedelijns GGZ. Door preventie meer te integreren met welzijnsvoorzieningen en gemeentelijke voorzieningen gericht op gezondheidsbevordering wordt ze toegankelijker.

Samenwerking mogelijk maken op gemeentelijk niveau

Juist op gemeentelijk niveau zijn gezondheidszorginstellingen het best samen te brengen rondom preventie. We denken hierbij aan GGZ-instellingen, GGD'en, lokale organisaties voor welzijn, verslavingszorg en eerstelijns zorgaanbieders. Daardoor kan meer volgens geïntegreerde zorgmodellen gewerkt worden van vroegherkenning, verwijzing en preventie tot behandeling. Een succesvol voorbeeld van zo'n benadering is de Integrale Aanpak Depressiepreventie bij ouderen: een wijkgerichte aanpak waarbij GGD-en en overige relevante partijen op een gestructureerde en gerichte manier met elkaar samenwerken. Het verdient aanbeveling om dit ook uit te werken voor de andere leeftijdsgroepen. De wettelijk vereiste vierjaarlijkse gemeentelijke nota gezondheidsbeleid biedt hiervoor kansen. Een toegankelijk overzicht van gestandaardiseerde en effectieve preventieprogramma's en een leidraad voor een integrale aanpak van preventie zouden gemeenten hierbij kunnen ondersteunen.

\section{Preventie van psychische stoornissen als vast onderdeel van gezondheidszorg}

Preventie als lichtste behandeloptie in model van getrapte zorg

De gezondheidszorg wordt steeds meer geordend volgens de 'stepped-care' benadering, ook 'getrapte zorg' of 'ketenzorg' genoemd. Daarin wordt het zorgaanbod aangepast aan de ernst van de klachten van de zorgvrager. Dit is een efficiënte vorm van werken: bij lichte klachten voldoet immers vaak een niet-ingrijpende behandeling. Preventie, en met name preventie bij mensen met beginnende klachten, leent zich goed als minst ingrijpende interventie in zo'n zorgketen. Veel van de mensen met beginnende psychische klachten worden immers gezien bij de zorg en vooral de eerstelijn. In de theoretische en praktische uitwerking van de getrapte zorg voor psychische stoornissen is aan preventie nog veel te weinig aandacht besteed. 
Kennis over GGZ preventie toepassen binnen de nulde- en eerstelijn

Preventieafdelingen van de tweedelijns GGZ hebben veel expertise in het ontwikkelen en uitvoeren van geïndiceerde preventie. Het preventieaanbod vanuit een GGZ-instelling heeft echter een wat weggestopte positie. Zo voelen veel mensen een hoge drempel om hulp te zoeken bij een GGZ-instelling, ook al gaat het om preventie. De expertise van de tweedelijns GGZ wordt daarom steeds meer ingezet binnen de nulde en de eerstelijn. Om de bereikbaarheid van preventieve interventies te vergroten is het noodzakelijk dat deze trend zich verder voortzet.

\section{Geïndiceerde preventie inpassen in eerstelijn}

Systematische geïndiceerde preventie vindt op dit moment nog maar zeer beperkt plaats in de eerstelijn. De Doorbraakprojecten Depressie laten zien dat het mogelijk is om huisartsen een belangrijke rol te geven in het uitvoeren van en/of verwijzen naar gestandaardiseerde en bewezen effectieve preventieve interventies. Dat geldt ook voor sociaal-psychiatrisch verpleegkundigen in de huisartsprakijk, het algemeen maatschappelijk werk, de thuiszorg en eerstelijnspsychologen. Voor mensen bij wie geïndiceerde preventie niet voldoende blijkt te zijn, is het behandelaanbod binnen de eerstelijn doorgaans een passend vervolg. Daarmee is de eerstelijn een belangrijke schakel in de ketenzorg van preventie naar behandeling.

\section{Geïndiceerde preventie opnemen in evidence-based richtlijnen}

Systematische geïndiceerde preventie van psychische stoornissen maakt nog geen onderdeel uit van de NHG-standaarden voor de huisartsen, en evenmin staat het in de multidisciplinaire richtlijnen voor de GGZ. Deze richtlijnen zouden bij de eerstvolgende herziening meer moeten worden opgebouwd volgens de stepped-care benadering, waarbij geïndiceerde preventie als eerste stap verankerd wordt in het model van getrapte zorg. Vooral over de effectiviteit van de geïndiceerde preventie van depressie bestaat inmiddels voldoende evidentie om zo'n herziening te rechtvaardigen. De overzichten met de bewijskracht voor de effectiviteit in dit rapport kunnen daarbij dienstdoen als bron.

\section{Werving voor preventie: van aanbodgericht naar vraaggericht}

Tot nu toe worden de deelnemers vooral per afzonderlijke preventieve interventie voor psychische stoornissen geworven; dat is inefficiënt. Het zou beter zijn om (op regionaal niveau) deelnemers te werven met een breed aanbod van preventieve interventies, passend bij de diversiteit in hulpvraag en persoonlijke voorkeuren. Zo kunnen mensen zelf kiezen welke preventieve interventie het beste bij hen past.

\section{Verheldering financiering binnen zorgverzekering}

De financiering van preventieve interventies binnen de Zorgverzekeringswet is op dit moment niet helder geregeld. De DBC's voor de GGZ zijn echter nog in ontwikkeling. Het verdient aanbeveling om daarbij ook een of meer heldere DBC's voor geïndiceerde preventie te ontwikkelen. Deze zijn in de voorlopige DBC-structuur zoals deze medio 2006 bestond, nog niet opgenomen. Met zulke DBC's wordt preventie zichtbaar als aparte interventievorm naast behandeling én is de vergoeding gegarandeerd. Op dit moment wordt door de zorgaanbieders vooral gezocht naar mogelijkheden om preventieve inter- 
venties vergoed te krijgen binnen de DBC's voor lichte stoornissen. Een nadeel van deze pragmatische aanpak is dat er onduidelijkheid blijft bestaan of geïndiceerde preventie wel of niet vergoed wordt. Overigens zullen de aanbieders van meer universeel gerichte preventieve interventies, die per definitie buiten de DBC's vallen, sowieso met de zorgverzekeraars moeten onderhandelen over de vergoeding daarvan. 


\section{INLEIDING EN DOEL VAN HET RAPPORT}

\subsection{Aanleiding en achtergrond}

In de kabinetsnota 'Langer gezond leven, ook een kwestie van gezond gedrag' presenteerde het kabinet haar beleid ten aanzien van het bevorderen van de gezondheid van de Nederlandse bevolking tussen 2004 en 2007 (VWS, 2003). Er werd in deze nota een groot aantal onderwerpen op het terrein van preventie vastgesteld waarop in de komende jaren actie moest worden ondernomen. De voorkeur ging in de nota uit naar ziekten die:

- een hoge ziektelast veroorzaken;

- samenhangen met de vergrijzing;

- leiden tot veel zorggebruik;

- maatschappelijke participatie en arbeidsbeschikbaarheid negatief beïnvloeden;

- preventief aangepakt kunnen worden;

- samenhangen met sociaal-economische gezondheidsverschillen.

In eerste instantie werden de volgende zes ziekten(clusters) gekozen: hart en vaatziekten, kanker, astma, diabetes mellitus, psychische klachten en klachten aan het bewegingsapparaat. Binnen het zeer brede terrein van de psychische klachten voldeden met name veelvoorkomende psychische stoornissen als depressie, angststoornissen en schadelijk alcoholgebruik aan veel van de eerdergenoemde eisen. Het kabinet koos ter preventie van de genoemde clusters vervolgens drie speerpunten voor concrete preventieve maatregelen: roken, overgewicht en diabetes mellitus.

Het voorkómen van psychische stoornissen werd in deze nota dus niet expliciet benoemd tot speerpunt van beleid. Toch vormde de preventie van psychische stoornissen volgens het kabinet wel een belangrijke prioriteit. Hoofdstuk 6 van de nota 'Langer gezond leven, ook een kwestie van gezond gedrag' was daarom in zijn geheel gewijd aan psychische stoornissen (VWS, 2003a). In hetzelfde hoofdstuk van de nota vroeg het kabinet het RIVM en het Trimbos-instituut een beleidsonderbouwende notitie te schrijven voor de verdere beleidsontwikkeling van de preventie van psychische stoornissen waaronder depressie. Deze kennisvraag heeft uiteindelijk geleid tot dit VTV-Themarapport. Eerdere versies van het rapport zijn al voorgelegd aan de schrijvers van de nieuwe preventienota, waardoor onze bevindingen konden worden meegenomen in de inmiddels verschenen nieuwe preventienota van het kabinet 'Kiezen voor gezond leven' (VWS, 2006d). Mede op grond van de bevindingen uit de conceptversies van dit rapport is in deze nota naast schadelijk alcoholgebruik ook depressie opgenomen als expliciet speerpunt.

Bij de uitwerking van de kennisvraag in hoofdstuk 2 hebben we gebruik gemaakt van de boven beschreven eisen voor de prioritering van ziekten in de preventienota. Daarnaast hebben we de aanbevelingen voor preventie uit het vorige VTV-rapport 'Gezondheid op Koers?' (Van Oers, 2002) goed bestudeerd. De grootste kansen voor verdere winst op het terrein van gezondheid lagen volgens dit rapport bij de verbetering van 
ongezond gedrag. De preventie van ongezond gedrag werd onder meer bemoeilijkt door onvoldoende inbedding van preventie in de zorg en te weinig structurele ondersteuning voor preventieprogramma's. Daarnaast werd onvoldoende gebruik gemaakt van lokale settings (school, wijk, werkplek) om succesvolle programma's uit te bouwen en werd de effectiviteit van preventieve interventies veel te weinig systematisch geëvalueerd. Volgens Van Oers (2002) was een langetermijn visie op preventie nodig.

Dit themarapport is niet alleen bedoeld om het ministerie van VWS te ondersteunen bij de verdere ontwikkeling van zo'n visie op preventie van psychische stoornissen. De informatie is ook van belang voor andere spelers op het gebied van de geestelijke gezondheid: GGD-en, GGZ-instellingen, instellingen voor verslavingszorg en categorale organisaties (patiëntenverenigingen, pedagogische centra). Het kan hen helpen bij de keuze van interventies binnen hun instelling/setting. Tevens hopen we dat het rapport zijn weg zal vinden naar andere belangrijke spelers in de preventieve gezondheidszorg, zoals artsen, psychologen en SPV-en in de eerstelijn, maatschappelijk werk, en beleidmakers bij gemeenten.

\subsection{Waarom is de preventie van psychische stoornissen belangrijk?}

De aandacht voor preventie van psychische stoornissen in beleidsnota's is van vrij recente datum (zie bijlage 7 voor een beleidsgeschiedenis). De aandacht ging tot voor enkele jaren vooral uit naar de preventie van lichamelijke ziekten. Op grond van landelijke cijfers over de ernst en gevolgen van psychische stoornissen was die eenzijdige aandacht voor lichamelijke ziekten niet terecht. Uit recent verschenen rapporten, zoals de nieuwste VTV 'Zorg voor gezondheid' en de nieuwe 'Kosten van Ziekten'-studie blijkt dat psychische stoornissen wat betreft omvang, gevolgen en kosten niet onderdoen voor veel ernstige lichamelijke ziekten (De Hollander et al., 2006; Slobbe et al., 2006).

Uit tabel 1.1 blijkt dat angststoornissen, depressie en alcoholafhankelijkheid voorkomen in de top tien van ziekten en aandoeningen met de grootste ziektelast (voor een toelichting zie tekstblok 1.1). Ze zorgen samen voor $11,5 \%$ van alle ziektelast in Nederland. Ze staan zo hoog in deze lijst omdat ze voor veel verlies van kwaliteit van leven zorgen, bij heel veel mensen. De lichamelijke ziekten in de lijst komen meestal minder vaak voor, maar leiden wel tot meer vroegtijdige sterfte. Het is verder opvallend dat depressie en angststoornissen in verhouding veel vrouwen treft, terwijl alcoholafhankelijkheid vooral bij mannen voorkomt.

Uit de 'Kosten van Ziekten'-studie (Slobbe et al., 2006) blijkt dat in 2003 in totaal 57,5 miljard euro werd uitgegeven aan de gezondheidszorg in Nederland. Daarvan werd bijna een kwart (12,7 miljard; 22\%) uitgegeven aan psychische stoornissen. Binnen de psychische stoornissen waren het vooral de verstandelijke handicaps (4,6 miljard) en dementie (3,1 miljard) die de meeste kosten genereerden. Depressie (inclusief dysthymie) leidde tot 660 miljoen euro aan zorgkosten, angststoornissen tot 275 miljoen 
Tabel 1.1: Top tien van de ziekten met de grootste ziektelast in DALY's in Nederland in 2003 (Bron: De Hollander et al., 2006).

\begin{tabular}{lllll}
\hline Rangorde & \% van totaal & Mannen & Vrouwen \\
\hline 1 & Coronaire hartziekten & 7,6 & Coronaire hartziekten & Angststoornissen \\
2 & Angststoornissen & 5,1 & Beroerte & Coronaire hartziekten \\
3 & Beroerte & 4,9 & Alcoholafhankelijkheid & Beroerte \\
4 & Depressie/dysthymie & 3,9 & Longkanker & Depressie en dysthymie \\
5 & COPD & 3,2 & COPD & Borstkanker \\
6 & Diabetes mellitus & 3,2 & Angststoornissen & Diabetes mellitus \\
7 & Longkanker & 3,0 & Diabetes mellitus & Artrose \\
8 & Alcoholafhankelijkheid & 2,5 & Depressie/dysthymie & Dementie \\
9 & Artrose & 2,5 & Verkeersongevallen & COPD \\
10 & Dementie & 2,3 & Ongevalsletsel privé & Longkanker \\
\hline
\end{tabular}

euro en afhankelijkheid van alcohol en drugs samen tot zo’n 360 miljoen euro. Deze zorgkosten zijn aanzienlijk, maar in verhouding tot die van veel lichamelijke ziekten niet overdreven hoog. Dat komt omdat veel mensen met psychische stoornissen geen hulp zoeken. Degenen die wel hulp zoeken, ontvangen meestal alleen ambulante hulp en worden niet opgenomen.

De maatschappelijke kosten van psychische stoornissen zijn vooral terug te zien in ziekteverzuim en arbeidsongeschiktheid. Psychische stoornissen en klachten vormen met de klachten aan het bewegingsapparaat al tientallen jaren de belangrijkste oorzaken voor langdurig ziekteverzuim (Veerman et al., 2001). In 2002 ontvingen 40 duizend van alle 108 duizend nieuwe arbeidsongeschikten (37\%) een psychische diagnose van de verzekeringsarts. Stemmingsstoornissen vormden met ruim 11.000 nieuwe arbeidsongeschikten een van de grootste diagnosegroepen. Dat is bijna $11 \%$ van alle nieuwe arbeidsongeschikten.

Er zijn globaal twee manieren om deze enorme ziektelast te verminderen; voorkomen dat mensen gaan lijden aan een psychische stoornis en het behandelen van mensen die al lijden aan een psychische stoornis. Naar het effect van de behandeling van psychische stoornissen is inmiddels enorm veel onderzoek gedaan. Deze kennis wordt in Nederland vastgelegd in 'evidence-based' (gebaseerd op wetenschappelijke en klinische evidentie) multidisciplinaire richtlijnen voor behandeling (Offringa et al., 2003). Over het exacte effect van de gezondheidszorg op de ziektelast door psychische stoornissen in de gehele bevolking in Nederland kunnen geen harde uitspraken worden gedaan (Westert \& Verkleij, 2006). Wel is in een groot Australisch onderzoeksproject enkele jaren terug een schatting gemaakt van de effectiviteit van de Australische GGZ, uitgedrukt in een vermindering van de ziektelast (Andrews et al., 2003; 2004). Deze Australische resultaten zijn met enige slagen om de arm ook toepasbaar in de Nederlandse situatie (Beekman et al., 2006; De Hollander et al., 2006). De onderzoekers lieten zien dat de GGZ de ziektelast inderdaad verminderde. Door een groter bereik en het standaard gebruik van evidence-based behandelingen zou het effect van de GGZ nog omhoog kunnen, tot maximaal 40\% van de gehele ziektelast als gevolg van psy- 


\section{Tekstblok 1.1: Berekening van ziektelast in DALY's.}

De ziektelast wordt weergegeven in DALY's, een afkorting van Disability-Adjusted Life-Years. Dit betreft een maat voor de hoeveelheid gezondheidsverlies in een populatie die veroorzaakt wordt door ziekte. DALY's per ziekte zijn opgebouwd uit twee onderdelen: jaren geleefd met ziekte (ziektejaar-equivalenten) en vroegtijdige sterfte als gevolg van ziekte (De Hollander et al., 2006).

\section{Ziektejaar-equivalenten}

De jaren geleefd met de ziekte worden met behulp van wegingsfactoren tussen 0 en 1 'gewogen' voor de ernst van de ziekte, zodat ze vergelijkbaar worden met de door sterfte verloren levensjaren (Stouthard et al., 1997). De wegingsfactor van depressie bedraagt bij voorbeeld 0,46 (Kruijshaar et al., 2003); dat wil zeggen dat een jaar met depressie in de DALY-berekening bijna evenveel gewicht in de schaal legt als een half jaar eerder overlijden. De ziektejaar-equivalenten worden berekend over de gehele populatie. Daarbij gebruikt men niet de jaarprevalentie - zoals we doen in de rest van het rapport - maar de maandprevalentie. De jaarprevalentie zou een overschatting geven van het aantal patiëntjaren geleefd met de ziekte, omdat een deel van de mensen niet het gehele jaar de stoornis heeft gehad. Ziektejaar-equivalenten worden berekend door de maandprevalentie te vermenigvuldigen met de wegingsfactor.

\section{Verloren levensjaren door vroegtijdige sterfte} Het aantal verloren levensjaren door vroegtijdige sterfte als gevolg van psychische stoornissen is moeilijk te achterhalen. Voor de berekening ervan wordt gebruik gemaakt van de doodsoorzakenstatistiek van het CBS. Hierin is weliswaar ook een aantal psychische stoornissen als primaire doodsoorzaak geregistreerd, maar met uitzondering van sterfte door gebruik van alcohol zijn die aantallen erg laag. Hier is sprake van een onderschatting, bijvoorbeeld omdat suïcide als gevolg van psychische stoornissen hierin niet wordt meegeteld.

\section{Effect behandeling op de vermindering van de ziektelast in de bevolking \\ In de doorrekening van de effecten van interven- ties wordt het effect van de interventies waar mogelijk uitgedrukt in het aantal voorkomen gevallen van de ziekte in de hele bevolking (paragraaf 2.5). Dat aantal voorkomen gevallen vormt de basis voor de berekening van het aantal voorkomen DALY's. Daarbij wordt het daadwerke- lijk aantal voorkomen gevallen vermenigvuldigd met de wegingsfactor en vervolgens vermenig- vuldigd met de verwachte duur van de ziekte in het eerste jaar na de interventie. Voor depressie is de wegingsfactor 0,46 en de gemiddelde duur van een depressieve episode 0,5 jaar (Kruijshaar et al., 2003). Wanneer bij 100 mensen depressie wordt voorkomen, levert dat in het eerste jaar dus 23 DALY's op.}

\section{Ziektelastberekeningen voor de aanwezigheid van ernstige klachten \\ Voor veel van de in dit rapport beschreven interventies is het effect niet berekend in de vorm van aantallen nieuwe gevallen met een officiële diagnose, maar als vermindering van klachten. Op enkele plaatsen werden daarom aangepaste DALY-berekeningen uitgevoerd. Daarbij werd gebruik gemaakt van een wegingsfactor voor milde gevallen. Zo namen Chisholm et al. bijvoor- beeld voor probleemdrinken niet de algemene wegingsfactor maar de wegingsfactor voor een milde stoornis: 0,15 (Chisholm et al., 2004).}

chische stoornissen. Dat betekent voor Nederland dat met behandeling een flink deel van de ziektelast van psychische stoornissen kan worden verminderd, maar zeker niet de gehele ziektelast (Beekman et al., 2006). Dit pleit er voor om naast behandeling ook preventie aan te bieden, om zo de ziektelast nog wat verder terug te dringen.

\section{Onderzoeksvraag}

Deze conclusie leidt automatisch tot de vraag naar de mogelijke bijdrage van preventie aan het verminderen van de ziektelast. Is het mogelijk om met preventieve interventies het ontstaan van psychische stoornissen tegen te gaan, om zo de ziektelast en de daarmee samenhangende kosten te verminderen? Dat is de centrale vraagstelling van dit rapport. Om deze onderzoeksvraag te beantwoorden integreerden we bestaande kennis uit verschillende bronnen. 


\subsection{Effectieve preventie van psychische stoornissen}

De preventie van psychische stoornissen is lang een gebied geweest waar goede bedoelingen de boventoon voerden. Dit terrein is de laatste jaren sterk aan het professionaliseren en verwetenschappelijken. Het aantal goede effectstudies groeit, waardoor het steeds beter mogelijk wordt uitspraken te doen over het werkelijke effect ervan (Beekman et al., 2006; Cuijpers et al., 2005c). Het bleek goed mogelijk om de preventieve interventies te beoordelen volgens de inzichten uit de evidence-based medicine zoals die ook worden gehanteerd in de multidisciplinaire richtlijnen voor behandeling (Offringa et al., 2003). Dat betekent concreet dat we de nadruk leggen op gecontroleerd gerandomiseerd onderzoek (RCT's), uitgevoerd met deugdelijke uitkomstmaten (Schoemaker et al., 2006).

In dit rapport richten we ons in eerste instantie op preventieve interventies waarvan het bewijs is geleverd dat ze het ontstaan van depressie, angststoornissen en alcoholmisbruik en -afhankelijkheid kunnen voorkomen (in paragraaf 2.1 staan de in dit rapport gehanteerde definities voor deze psychische stoornissen beschreven, waarbij ook uitgebreid aandacht wordt besteed aan de verschillende termen voor schadelijk alcoholgebruik). Inzicht in het effect op het aantal nieuwe gevallen biedt vervolgens mogelijkheden om effecten op bevolkingsniveau door te rekenen. Dat doen we door in navolging van de Australische onderzoekers de resultaten van de effectstudies te combineren met epidemiologische gegevens, zorgregistraties en kostenberekeningen (Andrews et al., 2004). We weten immers wat iemand met een diagnose zoals depressie aan ziektelast ervaart en aan kosten genereert. Net als bij de Australische studie is het bereik van de interventies een belangrijke factor in het berekenen van de effecten op bevolkingsniveau. Over het aantal instellingen dat de interventie aanbiedt, en het aantal mensen dat deelneemt aan de interventies is vaak niet zo veel bekend; daarom berekenen we de effecten in enkele bereikscenario's.

Naast onderzoek naar het voorkomen van nieuwe gevallen hebben we ook aandacht besteed aan onderzoek met andere stoornisspecifieke uitkomstmaten, zoals vermindering van klachtenniveau (hoofdstuk 2). Deze onderzoeken lenen zich niet altijd voor dergelijke doorrekeningen. Onderzoek naar terugvalpreventie of naar tertiaire preventie hebben we buiten beschouwing gelaten; deze interventies richten zich immers niet op het voorkómen van nieuwe gevallen (tabel 2.1). De consequenties van deze keuzes worden in hoofdstuk 6 besproken.

\subsection{Inhoud en leeswijzer}

In hoofdstuk 2 worden de methodologische uitgangspunten - zoals de nadruk op voorkómen van stoornissen, de aandacht voor de wetenschappelijke bewijskracht en de doorrekening naar bevolkingsniveau - nader uitgewerkt. De technische details staan in bijlage 2. 
In de daaropvolgende drie hoofdstukken staat telkens één stoornis centraal: depressie (hoofdstuk 3), angststoornissen (hoofdstuk 4), en alcoholmisbruik en -afhankelijkheid (hoofdstuk 5). Ieder van deze hoofdstukken kent dezelfde opbouw in paragrafen:

1. definitie, beloop en doelgroepen voor preventie;

2. omvang, ernst en gevolgen;

3. preventieve interventies bij jongeren;

4. preventieve interventies bij volwassenen;

5. preventieve interventies bij ouderen;

6. samenvatting en conclusies.

Elke paragraaf over preventieve interventies (paragraaf 3, 4 en 5) bevat drie subparagrafen. In de eerste subparagraaf worden de in Nederland beschikbare interventies besproken. In de tweede subparagraaf wordt aan de hand van effect-onderzoek nader ingegaan op de gezondheidseffecten van bewezen effectieve interventies. Daarbij kijken we ook naar buitenlandse interventies die wellicht een welkome aanvulling zouden zijn op het huidige aanbod in Nederland. De derde subparagraaf ten slotte geeft een indicatie van de te behalen gezondheidswinst van preventieve interventies. Elk hoofdstuk wordt afgesloten met een samenvatting van de resultaten, conclusies en aanbevelingen.

In hoofdstuk 6 worden de conclusies uit de drie eerdere hoofdstukken geïntegreerd. Daarbij wordt ook stilgestaan bij de consequenties van de uitgangspunten en aannamen op de resultaten. Dit hoofdstuk bevat ook aanbevelingen voor nader onderzoek. Daarna volgt nog een laatste hoofdstuk (hoofdstuk 7). Hierin worden de onderzoeksbevindingen uit de voorgaande hoofdstukken vertaald in praktische, organisatorische en beleidsaanbevelingen. Deze zijn vooral gericht op het bevorderen van een evidencebased aanbod en het verhogen van het bereik. 


\section{VRAAGSTELLING EN METHODE}

Zoals vermeld in hoofdstuk 1 is de vraagstelling van dit themarapport als volgt: Welke mogelijkheden zijn er om met preventie het ontstaan van psychische stoornissen te voorkomen, en daarmee de ziektelast en kosten van psychische stoornissen te reduceren?

Deze vraagstelling hebben we uitgesplitst in vijf deelvragen.

1. Wanneer lijdt iemand aan een van de geselecteerde psychische stoornissen?

2. Wat zijn op bevolkingsniveau de ernst, omvang en gevolgen van deze psychische stoornissen in Nederland?

3. Welke preventieve interventies zijn in Nederland beschikbaar ter voorkoming van deze psychische stoornissen?

4. Is het mogelijk om met dergelijke interventies bij de individuele deelnemers het ontstaan van deze psychische stoornissen te voorkomen?

5. Is het mogelijk deze gezondheidswinst als gevolg van preventie door te rekenen naar omvang, ernst en gevolgen op bevolkingsniveau?

In de onderstaande paragrafen geven we voor iedere deelvraag een korte beschrijving van de gegevens die we gebruikt hebben om elk van de deelvragen te beantwoorden. Daarnaast beschrijven we de belangrijkste methodologische aannamen en keuzes. Ook lichten we de belangrijkste termen toe. Voor een uitgebreide methodologische verantwoording van de hier besproken onderwerpen verwijzen we naar bijlage 2 .

\subsection{Definitie en afbakening psychische stoornissen}

Uitgangspunt bij de beschrijving van de psychische stoornissen voor dit rapport is de classificatie van psychische stoornissen volgens de 'Diagnostic and Statistical Manual of Mental Disorders 4th edition' (DSM-IV; American Psychiatric Association (APA), 2001). Voordeel van deze classificatie is dat de ziektebeelden helder omschreven zijn en dat het systeem aansluit bij internationaal onderzoek. Ook geeft het een ondergrens aan van de ernst van de te voorkomen stoornissen. De problematiek moet immers ernstig genoeg zijn om te voldoen aan de diagnostische criteria volgens de DSM-IV. Psychische stoornissen die niet binnen de diagnostische criteria van de DSM-IV passen, vallen dan ook buiten het aandachtsgebied van dit themarapport.

Bij de selectie van de stoornisgroepen binnen de DSM-IV zijn we uitgegaan van de prioriteiten in de nota 'Langer gezond leven, ook een kwestie van gezond gedrag' (VWS, 2003a): stemmingsstoornissen, angststoornissen en alcoholmisbruik en -afhankelijkheid. Deze stoornissen komen zeer veel voor in de bevolking, veroorzaken een hoge ziektelast en leiden tot veel zorggebruik. Daarnaast beïnvloeden ze de maatschap- 
pelijke participatie en de arbeidsbeschikbaarheid negatief. Binnen deze drie stoornisgroepen hebben we vervolgens nog een nadere selectie aangebracht.

Binnen de hoofdgroep stemmingsstoornissen (hoofdstuk 3) gaan we alleen in op de psychiatrische diagnose 'depressieve stoornis', omdat deze vaker voorkomt dan de andere stemmingsstoornissen, er meer onderzoek is verricht naar de preventie ervan, en de depressieve stoornis bewezen beïnvloedbaar is door preventie. Als we in dit rapport de term depressie gebruiken dan wordt daarmee de depressieve stoornis bedoeld.

Binnen de hoofdgroep angststoornissen (hoofdstuk 4) worden de stoornissen met een lage prevalentie (zoals de obsessief-compulsieve stoornis) of waarvoor onvoldoende wetenschappelijke kennis over preventie is (specifieke fobie, posttraumatische stressstoornis, acute stressstoornis) niet afzonderlijk besproken. We gaan alleen nader in op sociale fobie, paniekstoornis (met of zonder agorafobie) en gegeneraliseerde angststoornis. Omdat veel epidemiologisch onderzoek geen uitsplitsing naar stoornis toelaat worden de overige angststoornissen doorgaans wel meegeteld in de berekeningen van de omvang en ernst.

Alcoholmisbruik en -afhankelijkheid (hoofdstuk 5) behoren in de DSM-IV tot de hoofdgroep 'aan een middel gebonden stoornissen'. Binnen deze hoofdgroep vallen ook 'afhankelijkheid en misbruik van drugs', maar deze blijven in dit rapport buiten beschouwing. Overigens wordt in het meeste onderzoek het schadelijk alcoholgebruik niet gedefinieerd volgens de DSM-IV. Meestal wordt de International Classification of Diseases (ICD) gebruikt. De ICD spreekt van 'harmful use' en alcoholafhankelijkheid als het gaat om alcoholproblemen. Het equivalent voor harmful use is 'schadelijk alcoholgebruik' of 'probleemdrinken'. In de meeste overheidsstukken wordt tegenwoordig ook gesproken van probleemdrinken (harmful use) en schadelijk alcoholgebruik ('hazerdous use' waarbij nog geen problemen zichtbaar zijn, maar dat op termijn wel tot problemen zal leiden) en worden de epidemiologische gegevens uit een studie van Van Dijck en Knibbe (2005) gebruikt (zie bijvoorbeeld VWS, 2006d). We kozen voor de consistentie in dit rapport waar mogelijk voor de DSM-diagnoses, alleen waar die in onderzoek ontbraken maakten we gebruik van andere definities.

Bij de beschrijving van iedere stoornis (hoofdstuk 3, 4 en 5) wordt onderscheid gemaakt tussen drie afzonderlijke leeftijdsgroepen: jongeren (13 tot en met 17 jaar), volwassenen (18 tot en met 64 jaar) en ouderen (65+ jaar). Kinderen tot en met 12 jaar zijn niet opgenomen in dit rapport, omdat de toepassing van DSM-criteria voor het stellen van een psychiatrische diagnose bij deze leeftijdsgroep minder geschikt is.

\subsection{Omvang, ernst en gevolgen op bevolkingsniveau}

Voor de beschrijving van de omvang, ernst en gevolgen van de gekozen psychische stoornissen hebben we een aantal indicatoren gebruikt. Deze staan uitgebreid beschreven in bijlage 2 . Hieronder geven we een kort overzicht van de gebruikte indicatoren: 
- Kenmerken van de stoornis: definitie, beloop en doelgroepen voor preventie. De beschrijving van kenmerken is zoals gezegd gebaseerd op de DSM-IV (APA, 2001). Voor de beschrijving van de mogelijke doelgroepen voor preventie baseren we ons voornamelijk op epidemiologisch onderzoek naar determinanten van psychische ongezondheid (Maas \& Jansen, 2000).

- Omvang: De omvang van psychische stoornissen is uitgedrukt in jaarprevalentie en incidentie.

- Met jaarprevalentie wordt bedoeld het percentage personen dat in een periode van één jaar voorafgaand aan de peiling leed aan de stoornis. Dit kunnen zowel nieuwe als bestaande gevallen zijn.

- Onder incidentie verstaan we het aantal personen dat het jaar voorafgaand aan de peiling voor het eerst leed aan de stoornis. Dit wordt uitgedrukt in het aantal nieuwe gevallen per 100 persoonsjaren (de totale persoonstijd die is geobserveerd).

De incidentie en prevalentie zijn weergegeven in percentages en in aantallen, gestandaardiseerd naar de bevolkingsopbouw van 2003. Voor prevalentie- en incidentiecijfers gebruiken we de uitkomsten van epidemiologisch onderzoek, waar mogelijk van de Nederlandse bevolking. Wanneer de uitkomsten gepresenteerd zijn in 1maands- of 6-maandsprevalenties, hebben we deze cijfers omgerekend naar jaarprevalenties. Bij het ontbreken van Nederlandse cijfers maken we gebruik van internationale bronnen. Kanttekening bij prevalentiecijfers uit epidemiologisch onderzoek is dat ze de werkelijke omvang van psychische stoornissen in de algemene bevolking onderschatten. Dit komt omdat sociaal kwetsbare groepen zoals daklozen of mensen die langdurig zijn opgenomen niet worden bereikt bij epidemiologisch onderzoek. Juist bij deze groepen komen psychische stoornissen meer dan gemiddeld voor.

- Ernst: De ernst van een stoornis wordt beschreven in de vorm van ziektelast, uitgedrukt in DALY's (Disability-Adjusted Life-Years). Dit is een maat voor de hoeveelheid gezondheidsverlies in een populatie die veroorzaakt wordt door ziekten. In tekstblok 1.1 zijn de DALY-berekeningen toegelicht.

- Gevolgen: De gevolgen van een psychische stoornis bespreken we in termen van zorggebruik en zorgkosten, ziekteverzuim en kosten van ziekteverzuim en arbeidsongeschiktheid. Toelichtingen op de economische berekeningen staan in de tekstblokken 2.1 en 3.1 en in bijlage 2.

\subsection{Kenmerken van de aangeboden preventieve interventies}

Het aanbod van preventieve interventies in Nederland staat kort beschreven in ieder hoofdstuk. Een uitgebreidere beschrijving van deze interventies is te vinden in de bijlagen 3,4 en 5. Na een kort overzicht van de geraappleegde bronnen besteden we hieronder aandacht aan drie belangrijke kenmerken van de interventies: de aard van de doelgroep, de aanbiedingsvorm en het ontwikkelingsniveau van de interventies. 


\section{Tekstblok 2.1: Economische kosten van psychische stoornissen.}

Voor het berekenen van de kosten van psychische stoornissen zijn twee verschillende bronnen beschikbaar: de Kosten van Ziekten-studie (Slobbe et al., 2006) en een economische doorrekening op grond van Nemesis (Smit et al., in druk-b). Beide datasets hebben gemeen dat de cijfers over zorggebruik en -kosten per jaar gekoppeld zijn aan diagnoses of diagnosegroepen.

In de KvZ-studie worden de totale kosten van de gezondheidszorg in 2003 'top-down' toegewezen aan diagnosegroepen. In Nemesis is aan personen in een grote steekproef (ruim zevenduizend mensen tussen 18 en 65 jaar) gevraagd welke zorg ze in het afgelopen jaar hebben ontvangen (Vollebergh et al., 2003). Aan deze zorgcontacten zijn vervolgens kosten toegerekend (Oostenbrink et al., 2004). Omdat van alle respondenten ook de psychische diagnose is vastgesteld, kunnen zo 'bottom-up' de gemiddelde zorgkosten per diagnose worden berekend (Smit et al., in druk-b; zie tekstblok 3.1).

Voor de berekening van de directe zorgkosten van de prevalente gevallen van stoornissen hebben we ons gebaseerd op de Kosten van Ziekten-studie (Slobbe et al., 2006). Omdat de Nemesis-studie zich beperkt tot de niet-geïnstitutionaliseerde Nederlandse bevolking is het aandeel van de ziekenhuisopnamen in de kosten per stoornis veel lager dan in de KvZ-data. Voor de schatting van de te voorkomen kosten van incidente gevallen gebruiken we de data van Smit et al., geëxtrapoleerd naar 2003. We verwachten immers in het eerste jaar van een stoornis vrijwel geen opnamen.

\section{Geraadpleegde bronnen}

Het overzicht van preventieve interventies voor psychische stoornissen is samengesteld op basis van verschillende bronnen. De belangrijkste bron is de databank van de Landelijke Steunfunctie Preventie (www.lsp-preventie.nl). Hierin staan alle preventieve interventies geregistreerd die door Nederlandse GGZ-instellingen worden aangeboden. Een andere belangrijke bron is de onlangs verschenen catalogus van GGZ Nederland, waarin veel in Nederland aangeboden preventieve interventies opgenomen zijn (GGZ Nederland, 2005). Deze catalogus bevat overwegend de meer bekende interventies die op meerdere locaties worden aangeboden en waarnaar ook enig effectonderzoek werd uitgevoerd. Deze twee bronnen samen geven een goed beeld van welke interventies in Nederland beschikbaar zijn, voor zover ze worden aangeboden door preventieafdelingen van GGZ-instellingen of door andere partijen (bijvoorbeeld het algemeen maatschappelijk werk) in samenwerking met deze afdelingen. Ook geven deze bronnen informatie over de wetenschappelijke status van de geregistreerde interventies. Daarnaast is van overzichtsstudies en raadpleging van deskundigen gebruik gemaakt om interventies op te sporen. Daarbij werden ook interventies opgespoord die (nog) niet in Nederland worden aangeboden, maar kansrijk lijken door positieve ervaringen in het buitenland.

\section{Aard van de doelgroep}

De preventieve interventies die we in dit themarapport beschrijven zijn allereerst ingedeeld naar de doelgroep waarop zij zich richten (zie ook Mrazek \& Haggerty, 1994): universele, selectieve en geïndiceerde preventie. Deze indeling, die in de GGZ heel gebruikelijk is, wijkt af van de indeling in primaire, secundaire en tertiaire preventie die in de meeste andere sectoren wordt gehanteerd. Binnen de GGZ-preventie is er sprake van doelgroepen die zich in een continuüm tussen ziek en niet-ziek bevinden, terwijl 
bij preventie in de somatische gezondheidszorg vooral onderscheid wordt gemaakt tussen wel ziek of niet-ziek.

\section{Universele preventie}

Aan het gezonde eind van het continuüm richten de interventies zich op gehele bevolkingsgroepen, ongeacht hun risicostatus. Universele preventie kan de vorm aannemen van: psycho-educatie, interventies gericht op gezondheidsbevordering en overheidsmaatregelen.

Doel van psycho-educatie is kennisoverdracht: de bevolking(-sgroepen) gericht informeren over psychische stoornissen, hoe zij vroegtijdig herkend kunnen worden, wat men er zelf aan kan doen, en bij wie men terecht kan voor verdere hulp wanneer dat nodig is. Psycho-educatie draagt niet direct bij aan gedragsverandering, maar beoogt vooral tot een attitudeverandering te komen: mogelijk voelen mensen zich minder geremd door schaamte om hun beginnende psychische problemen kenbaar te maken en er hulp voor te zoeken. Daarmee kan psycho-educatie de stap naar een meer gerichte vorm van preventie vergemakkelijken. Bij interventies die zich richten op gezondheidsbevordering - bijvoorbeeld op het versterken van de competentie - is naast kennisoverdracht en attitudeverandering ook gedragsverandering een doel. Leerlingen van scholen kan bijvoorbeeld geleerd worden beter te beseffen wat ze zelf willen met alcohol, minder speelbal te zijn van groepsdruk, en hun sociale vaardigheden te versterken. Interventies gericht op gezondheidsbevordering noemen we universeel wanneer ze aangeboden worden aan alle leerlingen van een school. Bij overheidsmaatregelen, ten slotte, kan gedacht worden aan maatregelen zoals accijnsverhoging om het gebruik van alcohol te reduceren.

\section{Selectieve preventie}

Hierbij richten interventies zich op specifieke bevolkingsgroepen waarvan bekend is dat zij een verhoogd risico hebben op het ontwikkelen van een stoornis. In de context van de GGZ valt bijvoorbeeld te denken aan interventies die zich richten op ouderen die recent hun partner hebben verloren. Uit onderzoek is namelijk bekend dat het verliezen van een levenspartner het risico op een depressie verhoogt. Andere voorbeelden zijn interventies gericht op mensen die een chronische lichamelijke ziekte hebben.

\section{Geïndiceerde preventie}

Geïndiceerde preventieve interventies richten zich op personen die al enkele symptomen van de betreffende stoornis hebben, maar nog niet voldoen aan de diagnostische criteria voor de volledige stoornis. Het gaat, met andere woorden, om de vroegsignalering van een beginnende stoornis en vroegtijdig ingrijpen om de neerwaartse gang van kwaad naar erger te voorkomen.

Tabel 2.1 geeft de indeling in universele, selectieve en geïndiceerde preventie schematisch weer in relatie tot de doelgroepen. De verhouding tussen de 'somatische' indeling van preventie en de doelgroepen is eveneens in de tabel opgenomen. De tabel laat 
tevens zien hoe preventie zich verhoudt tot cure en care. Zoals vermeld in hoofdstuk 1 laten we terugvalpreventie buiten beschouwing in dit rapport.

Tabel 2.1: Spectrum van preventie naar doelgroep.

\begin{tabular}{lllllll}
\hline & $\begin{array}{l}\text { Algemene } \\
\text { bevolking }\end{array}$ & $\begin{array}{l}\text { Groepen } \\
\text { met een } \\
\text { verhoogd } \\
\text { risico }\end{array}$ & $\begin{array}{l}\text { Groep met } \\
\text { enkele } \\
\text { symptomen }\end{array}$ & $\begin{array}{l}\text { Groep met } \\
\text { de stoornis }\end{array}$ & $\begin{array}{l}\text { Groep in } \\
\text { remissie }\end{array}$ & $\begin{array}{l}\text { Groep die } \\
\text { niet (of } \\
\text { partieel) } \\
\text { hersteld is }\end{array}$ \\
\hline $\begin{array}{l}\text { Indeling } \\
\text { GGZ }\end{array}$ & $\begin{array}{l}\text { Universele } \\
\text { preventie }\end{array}$ & $\begin{array}{l}\text { Selectieve } \\
\text { preventie }\end{array}$ & $\begin{array}{l}\text { Geïndi- } \\
\text { ceerde } \\
\text { preventie }\end{array}$ & $\begin{array}{l}\text { Behande- } \\
\text { ling }\end{array}$ & $\begin{array}{l}\text { Terugval- } \\
\text { preventie }\end{array}$ & $\begin{array}{l}\text { Nazorg en } \\
\text { rehabilitatie }\end{array}$ \\
$\begin{array}{l}\text { Indeling } \\
\text { somatisch } \\
\text { (grofweg) } \\
\text { Indeling } \\
\text { beleid }\end{array}$ & Primaire & $\begin{array}{l}\text { Primaire/ } \\
\text { precuntie }\end{array}$ & $\begin{array}{l}\text { secundaire } \\
\text { preventie }\end{array}$ & $\begin{array}{l}\text { Tertiaire } \\
\text { preventie }\end{array}$ & & \\
\hline
\end{tabular}

\section{Aanbiedingsvormen van preventieve interventies}

Universele preventie in de vorm van psycho-educatie kan op meerdere manieren worden aangeboden. Voorbeelden zijn media-campagnes of voorlichtingsactiviteiten op kleinere schaal. Gezondheidsbevorderende interventies bestaan meestal uit (onderdelen van) schoolprogramma's. Universele preventie in de vorm van overheidsmaatregelen bestaat tot nu toe meestal uit maatregelen om schadelijk gebruik van alcohol terug te dringen. Te denken valt aan accijnsverhoging op alcoholhoudende dranken.

Selectieve en geïndiceerde preventie in de GGZ bestaat dikwijls uit psychologische interventies die gebaseerd zijn op cognitief-gedragstherapeutische principes of interpersoonlijke therapie (tekstblokken 2.2 en 2.4). Zulke psychologische interventies kunnen op verschillende manieren aangeboden worden: via een groepscursus, lotgenotencontact of zelfhulpcursussen. In toenemende mate wordt ook het internet als aanbiedingsvorm ontdekt. Eenzelfde cursus kan in verschillende varianten worden aangeboden, afhankelijk van de doelgroep.

\section{Ontwikkelingsfase preventieve interventies}

De in Nederland aangeboden interventies verschillen nogal in hun ontwikkelingsniveau. Sommige interventies bevinden zich nog in een innovatief stadium, waarbij de inhoud van de interventie nog niet vaststaat. Deze interventies noemen we innovatief (I). Wanneer interventies verder zijn ontwikkeld en er een goed draaiboek voor bestaat, spreken we van gestandaardiseerde interventies of 'good practice' (G). Deze tweedeling in ontwikkelingsfase wordt bij alle interventies vermeld als een I of een G. Interventies die op dit moment alleen nog in het buitenland worden aangeboden, worden aangeduid met een $\mathrm{B}$. 


\section{Tekstblok 2.2: Preventieve interventies op basis van cognitieve therapie.}

Veel van de beschreven preventieve interventies voor depressie en angststoornissen zijn gebaseerd op de principes van de cognitieve therapie. In dit tekstblok beschrijven we in het kort de basisprincipes van deze therapeutische stroming.

Cognitieve therapie is gebaseerd op het idee dat de wijze waarop mensen hun ervaringen interpreteren van invloed is op hoe zij deze ervaringen beleven en ermee omgaan. Mensen zijn kwetsbaarder voor depressie wanneer zij meer geneigd zijn negatief te denken aan zichzelf, de wereld om hen heen en de toekomst. Cognitieve therapie is, kort gezegd, gericht op het herkennen, onderzoeken en veranderen van deze negatieve gedachten.

Het is een gestructureerde vorm van therapie die doorgaans vijftien tot twintig sessies duurt en zo- wel individueel als in groepsverband uitgevoerd kan worden. Voor preventieve doeleinden worden vrijwel altijd sterk ingekorte versies gebruikt, die in acht tot twaalf sessies uitgevoerd worden.

Er is imiddels een hele groep psychologische behandelingen ontstaan die variëren op het bovenbeschreven basisthema. Daarbij wordt ook veel gewerkt met een vorm van cognitieve therapie waarin gedragsmatige elementen zijn verwerkt, de zogenaamde cognitieve gedragstherapie. Daarin wordt in de beginfase van de therapie aandacht besteed aan zogeheten 'activity scheduling', waarbij de cursist systematisch nagaat of er wel voldoende positieve interacties tussen hem of haar en de omgeving plaatsvinden. Wanneer nodig verandert de cursist vervolgens zijn daginvulling. In tekstblok 2.4 wordt een preventieve interventie beschreven die is gebaseerd op cognitieve gedragstherapie.

\subsection{Gezondheidseffecten van preventieve interventies op individueel niveau}

Voor het bepalen van het effect van interventies baseren we ons op wetenschappelijk onderzoek. We bepreken ons daarbij tot de interventies waarnaar kwalitatief goed effectonderzoek is gedaan. De gezondheidseffecten van de preventieve interventies zijn in de hoofdtekst weergegeven in tabellen. In tekstblok 2.3 is een voorbeeld van zo'n tabel uitgewerkt, met een uitleg over de interpretatie van de gebruikte technische termen. Bij de beoordeling van de gevonden resultaten van effectonderzoek zijn de volgende drie aspecten van belang: de selectie van de studies, de bewijskracht van het gevonden onderzoek en de gebruikte effectmaten.

\section{Selectie van studies}

Bij het opsporen van effectstudies maakten we in eerste instantie gebruik van recent verschenen overzichtsstudies. Voor depressie waren dat: Cuijpers et al., aangeboden ter publicatie; Cuijpers \& Willemse, 2005; Merry et al., 2004 en Ruijter et al., 2005. Voor alcoholpreventie waren dat Babor et al. (2003), Chisholm et al. (2004) en Cuijpers et al., 2005a. Voor angststoornissen bestonden dergelijke overzichtsstudies nog niet. Enkele wetenschappelijke studies naar de effectiviteit van interventies gericht op de preventie van angststoornissen waren echter bij de auteurs bekend en werden eerder beschreven in Cuijpers \& Bohlmeijer (2001), Hudson et al. (2004) en Story et al. (2004). Voor alle stoornissen werden vervolgens bij de afwezigheid van zeer recente overzichtstudies nog aanvullende literatuursearches gedaan in Medline, Psychlit en Google Scholar. Ook de leden van de Wetenschappelijke Advies Commissie (bijlage 1) werd gevraagd om aanvullingen; dit leverde in totaal één extra studie op. 


\section{De wetenschappelijke bewijskracht van effectstudies}

Preventieve interventies kunnen variëren wat betreft de sterkte van het wetenschappelijk bewijs voor hun effectiviteit. Zo is het van belang op welk type onderzoek het bewijs berust (Offringa et al., 2003). Gerandomiseerd effectonderzoek wordt gezien als het type onderzoek dat het meest overtuigend bewijs levert (Schoemaker et al., 2006). Dit is in mindere mate het geval met onderzoek waarbij wel een vergelijkingsgroep aanwezig is, maar waarbij de proefpersonen niet gerandomiseerd werden over de condities. Zulk quasi-experimenteel onderzoek staat namelijk meer bloot aan systematische fouten (bias) dan gerandomiseerd onderzoek. Het bewijs wordt nog minder overtuigend gevonden wanneer het afkomstig is uit een onderzoek waarbij alleen gekeken werd naar de interventiegroep, dus zonder controlegroep. Het is dan niet goed meer na te gaan waardoor het effect teweeg wordt gebracht. Wij volgen hierbij de gebruikelijke criteria uit de evidence-based medicine, zoals die ook gevolgd werden in de Multidisciplinaire GGZ-Richtlijnen (Landelijke Stuurgroep Multidisciplinaire Richtlijnontwikkeling in de GGZ, 2005a). De volgende tabel geeft een beschrijving van deze criteria.

Tabel 2.2: Bewijskracht van onderzoek en conclusies over effectiviteit van preventieve interventies.

\section{Mate van bewijskracht van artikelen over de effectiviteit van een interventie}

A1 Systematische reviews die ten minste enkele studies van A2-niveau betreffen, waarbij de resultaten van de primaire studies consistent zijn

A2 Gerandomiseerde klinische trials van goede kwaliteit (gerandomiseerd, dubbelblind)

B Gerandomiseerde klinische trials van matige kwaliteit of onvoldoende omvang, of ander vergelijkend onderzoek (quasi-experiment)

C Niet-vergelijkend onderzoek (voor- en nameting in één groep)

D Mening van deskundigen, bijvoorbeeld de werkgroepleden

\section{Niveau van de conclusies}

**** Gebaseerd op minimaal 1 review van A1-niveau (zie boven), of ten minste 2 onafhankelijk uitgevoerde studies van niveau A2.

*** Gebaseerd op ten minste twee onafhankelijk van elkaar uitgevoerde studies van niveau B

** Gebaseerd op één onderzoek van niveau A2 of B, of meerdere onderzoeken van niveau C

* Gepubliceerde mening van deskundigen, of mening van werkgroepleden

Voor elk van de interventies staat het niveau (de bewijskracht) van de conclusies over de effectiviteit vermeld, in de vorm van een aantal sterren. Wanneer we het hebben over effectieve interventies dan spreken we altijd over interventies waarvoor de sterkte van het bewijs minstens twee sterren kreeg. In enkele gevallen wegen we buitenlandse effectstudies minder zwaar, bijvoorbeeld omdat we onzeker zijn of de interventie die daar bestudeerd werd wel op precies dezelfde manier in Nederland wordt uitgevoerd. In zulke gevallen scoorden we één ster minder. Omdat dergelijk kwalitatief goed onderzoek op dit terrein nog van vrij recente datum is, wordt het hoogste niveau van bewijskracht (vier sterren) in dit rapport nog niet gegeven.

Tot slot nog twee nuanceringen bij de interpretatie van de bewijskracht. Allereerst is het ontbreken van bewijs voor effectiviteit niet hetzelfde als een bewijs voor niet- 


\section{Tekstblok 2.3: Interpretatie tabellen met gezondheidseffecten van preventie.}

De gezondheidseffecten van onderzochte preventieve interventies zijn in de hoofdstukken 3, 4 en 5 per effectonderzoek weergegeven in een tabel. In deze tabellen staan veel statistische maten. Hieronder is de inhoud van tabel 3.8 weergegeven, met daaronder een uitleg van de gebruikte maten.

Tabel 2.3: Voorbeeldtabel over verandering in incidentie van depressie.

\begin{tabular}{lccc}
\hline & & $\begin{array}{c}\text { Interventiegroep } \\
(\mathrm{n}=107)\end{array}$ & $\begin{array}{c}\text { Controlegroep } \\
(\mathrm{n}=109)\end{array}$ \\
\hline Werd depressief & & 13 & 20 \\
Werd niet depressief & & 94 & 89 \\
Risico op depressie & & 0,12 & 0,18 \\
& & & \\
Risicoverschil (RV) & 0,06 & $(-0,02 \sim 0,14)$ & \\
Relatief risico (RR) & 0,67 & $(0,40 \sim 1,09)$ & \\
NNT & 16 & & \\
\hline $\mathrm{p}=0,05$ (1-zijdig) & & & \\
\hline
\end{tabular}

- Interventiegroep: De groep mensen binnen de totale onderzoeksgroep die de interventie heeft gekregen. Dit zijn 107 mensen.

- Controlegroep: De groep mensen binnen de totale onderzoeksgroep die géén interventie heeft gekregen. Dit zijn 109 mensen.

- Werd depressief: Na afloop van de interventie kregen 13 van de 107 mensen van de interventiegroep een depressie. In dezelfde periode kregen 20 (van de 109) mensen van de controlegroep een depressie.

- Werd niet depressief: Na afloop van de interventie kregen 94 van de 107 mensen uit de interventiegroep géén depressie. In dezelfde periode kregen 89 van de 109 mensen uit de controlegroep géén depressie.

- Risico op depressie: In de interventiegroep is het risico op depressie 0,12 . Dat houdt in dat $12 \%$ van de mensen uit de interventiegroep na afloop van de interventie een depressie krijgt, namelijk 13 van de 107 mensen.

- Risicoverschil (RV): Deze maat zegt iets over het verschil in risico op depressie tussen de interventiegroep en de controlegroep. In dit geval is het verschil 0,12 - 0,18 $=-0,06$. Dit betekent dat het risico op een depressie in de interventiegroep 6\% kleiner dan het risico op een depressie in de controlegroep.

- Relatief risico (RR): Deze maat zegt iets over de verhouding in het risico op depressie tussen de interventiegroep en de controlegroep. Deze verhouding wordt berekend door het risico op depressie in de interventiegroep te delen door het risico op depressie in controlegroep. In dit geval is dat 0,12 / 0,18 $=0,67$. Dit betekent dat het risico op een depressie met $33 \%$ gereduceerd wordt onder invloed van de interventie.

- NNT: Dit zijn de zogenaamde "numbers-needed-to-be-treated" (NNT). Dit is een maat voor de efficiëntie van een interventie. Deze maat wordt berekend als $1 / \mathrm{RV}$, in dit geval 1/0,06 $=16$. De NNT geeft weer hoeveel personen de interventie moeten ontvangen om bij één van hen het ontstaan van een depressie te voorkomen. In dit geval moeten 16 mensen de interventie ontvangen om bij één van hen een depressie te voorkómen / de risicostatus op te heffen. Hoe lager de NNT, hoe minder personen de interventie hoeven te ontvangen om één geval van depressie te voorkomen.

In deze tabel is het ontstaan van een ziekte de centrale uitkomstmaat. De RR, RV en NNT worden in andere tabellen ook berekend voor veranderingen in risicostatus. Het gaat dan om het al dan niet behouden van de ongunstige risicostatus, bijvoorbeeld excessief drinken als verhoogde risicostatus voor het (later) kunnen krijgen van diagnose alcoholafhankelijkheid. Wanneer de uitkomstmaat van de studie klachtenreductie betreft, worden er andere statistieken gerapporteerd. De meest belangrijke statististische maat is dan de gestandaardiseerde effectgrootte, $d$. Wanneer $d$ tussen de 0 en 0,32 ligt spreken we van een klein effect. Valt het tussen de 0,33 en de 0,55 dan heet het een middelgroot effect. Pas als het groter is dan 0,56 dan spreken we van een groot effect (Lipsey en Wilson, 1993). 
effectiviteit: de betreffende interventie kan effectief zijn, alleen weten we daar dan nog niets over. Daarnaast is het bewijs voor de effectiviteit van een interventie slechts één onderdeel van goede klinische praktijkvoering, want naast het bewijs voor de effectiviteit van een interventie wegen in de praktijk ook de klinische ervaring van de aanbieder mee en de voorkeuren van de ontvangers van de preventieve interventie (Offringa et al., 2003).

\section{Uitkomstmaten in de effectstudies}

De zeggingskracht van gerandomiseerde effectstudies hangt onder meer af van de gekozen uitkomstmaat. In dit rapport onderscheiden we drie soorten stoornisspecifieke uitkomstmaten: reductie van de incidentie, reductie van het risico dat iemand een stoornis ontwikkelt (dit wordt ook wel verandering in risicostatus genoemd), en reductie van het aantal stoornisspecifieke klachten. Voor een beschrijving van deze uitkomstmaten verwijzen we naar tekstblok 2.3. We vinden het bewijs sterker wanneer de primaire uitkomstmaat betrekking heeft op de incidentie van betreffende stoornis, minder sterk wanneer deze betrekking heeft op risicostatus, terwijl klachtenreductie de minste zeggingskracht heeft.

Als er voor interventies ook kosteneffectiviteitsanalyses (KEA's) zijn uitgevoerd, dan bespreken we die in de tekst. Daarnaast hebben we voor een van de interventies de economische effecten op een modelmatige wijze doorgerekend; deze berekeningen staan in bijlage 6 .

\subsection{Gezondheidswinst van preventieve interventies op bevolkingsniveau}

Bij het doorrekenen van de gezondheidswinst op bevolkingsniveau, beperken we ons tot de effecten in het eerste jaar na de start van de interventie. Deze keuze wordt ingegeven door het feit dat de beschikbare onderzoeken een follow-up kennen van maximaal een jaar. Over de effecten op lange termijn kunnen we dus niets met zekerheid zeggen. Deze tijdshorizon betekent onder meer dat arbeidsongeschiktheid en langdurige opnamen in een (psychiatrisch) ziekenhuis niet worden meegenomen in de berekeningen. Ook voor de gevolgen voor de ziektelast en de economische evaluaties werd de tijdshorizon op één jaar gesteld. Deze doorrekeningen zijn nader uitgewerkt in tekstblokken 1.1 en 2.1 .

Om de gezondheidswinst op bevolkingsniveau te berekenen is het nodig iets te weten over het bereik van de interventie: hoeveel mensen ontvangen de interventie per jaar? Hierover ontbreekt meestal betrouwbare informatie. In de gevallen dat we wel betrouwbare informatie hebben, dan blijkt het bereik tussen de 5 en de $25 \%$ van de doelgroep te liggen. Het bereik hangt ondermeer af van de wijze waarop personen worden geworven (advertenties in de media of via verwijzers), van de aanbiedingsvorm (groepscursus of via internet), van de aantrekkelijkheid van de interventie, en van het verwijsgedrag van allerlei professionals in het veld. 


\section{Tekstblok 2.4: Wat gebeurt er tijdens een preventieve interventie?}

$0 \mathrm{~m}$ een beeld te krijgen hoe een preventieve interventie er in de praktijk uitziet, beschrijven we hier de opzet van de cursus 'Geen Paniek' voor mensen met paniekklachten (paragraaf 4.4.1). De opzet van deze cursus is vergelijkbaar met die van veel andere preventieve interventies in dit rapport.

Het is, zoals veel preventieve interventies, een cursus gebaseerd op cognitieve gedragstherapie (tekstblok 2.2). De cursus kent een strakke, gestructureerde opbouw, en wordt begeleid door een professional, zoals een klinisch psycholoog. Deze cursusaanbieder volgt daarbij een gestandaardiseerd draaiboek. De cursisten krijgen een eigen cursusboek met gerichte psycho-educatie en opdrachten om zelf thuis mee aan de slag te gaan.

De cursus bestaat uit acht bijeenkomsten van twee uur en een terugkombijeenkomst na twee tot drie maanden. Het aanleren van vaardigheden die de deelnemers in staat stellen beter om te gaan met hun paniekklachten staan centraal. Deze vaardigheden houden concreet in:

- Leren omgaan met paniekklachten

- Informatie geven over levensstijl en paniekklachten

- Informatie geven over stressbronnen

- Ontspanningsoefeningen
- Meer greep krijgen op gedachten die de paniek doen toenemen

- Informatie geven over gedachten en angst

- Uitdagen van angstige gedachten

- Bedenken van rustgevende gedachten

- Opnieuw leren begeven in voor de deelnemers moeilijke situaties

- Informatie geven over gedragsoefeningen

- Angstthermometer opstellen

- Stap voor stap oefenen in de praktijk

Theoretische achtergronden, maar ook huiswerkopdrachten vormen belangrijke onderdelen van de cursus. Door middel van kennisoverdracht en het aanleren van specifieke vaardigheden worden beschermende factoren versterkt en risicofactoren verminderd. Elke bijeenkomst is als volgt opgebouwd:

- vorige bijeenkomst

- bespreken huiswerk

- vaardigheid/thema

- vooruitkijken volgende bijeenkomst

- huiswerk

De cursus wordt door de deelnemers in bijeenkomst acht geëvalueerd.

Om zicht te krijgen op een realistisch behaalbare gezondheidswinst versus een theoretisch maximaal te behalen gezondheidswinst, presenteren we telkens twee scenario's: een bereik van $25 \%$ en een bereik van $100 \%$ van de doelgroep. Het eerste is dan met een bepaalde inspanning realiseerbaar, het tweede geeft alleen het theoretisch maximum weer. De theoretisch maximaal haalbare gezondheidswinst helpt met de beoordeling van wat in werkelijkheid mogelijk is. De gezondheidswinst op bevolkingsniveau is in twee maten uitgedrukt: het aantal personen bij wie een stoornis vermeden werd (of een ongunstige risicostatus verloor) en de hoeveelheid voor kwaliteit van leven gecorrigeerde gewonnen levensjaren (DALY's; tekstblok 1.1).

Bij het maken van de gezondheidswinstberekeningen wordt de omvang van de doelgroep telkens gelijk gesteld aan het aantal personen dat voor het eerst in het betreffende jaar de stoornis ontwikkelt. Dit is immers de uiteindelijke doelgroep voor preventie. De incidentie-aantallen zoals beschreven in dit themarapport betreffen de mensen die voor het eerst in hun leven een stoornis krijgen. Preventie is zeker niet beperkt tot die groep, maar ook op personen die ooit eerder in hun leven een psychische stoornis heb- 
ben gehad en nu opnieuw een risico lopen opnieuw dezelfde psychische stoornis te krijgen. De schatting van het aantal personen bij wie een stoornis vermeden kan worden door preventie en het aantal daarmee gewonnen DALY's, is daarmee een conservatieve schatting. De vermoedelijke gezondheidswinst ligt dus waarschijnlijk hoger. 


\section{PREVENTIE VAN DEPRESSIE}

Dit hoofdstuk begint met een korte beschrijving van de kenmerken van depressie: definitie, beloop en doelgroepen voor preventie van depressie (paragraaf 3.1). Daarna geven we een overzicht van de epidemiologische kenmerken van depressie: omvang, ernst en gevolgen (3.2). In de daarop volgende paragrafen bespreken we preventieve interventies bij jongeren (3.3), bij volwassenen (3.4) en bij ouderen (3.5). Daarbij komen achtereenvolgens aan bod: de in Nederland beschikbare interventies, de gezondheidseffecten van effectieve interventies, en conclusies over de haalbare gezondheidswinst van preventieve interventies. Het hoofdstuk eindigt met een samenvatting en conclusies (3.6). Alle interventies worden beschreven in bijlage 3.

\subsection{Definitie, beloop en doelgroepen voor preventie}

De hieronder volgende informatie over depressie is grotendeels gebaseerd op bestaande overzichtsliteratuur. Voor een uitgebreide beschrijving van kenmerken, duur en beloop van depressie verwijzen we naar: APA (2001), Beekman en Ormel (1999), De Haan en De Wit (2000), Nolen en Koerselman (2000), Schoemaker et al. (2002), Spijker en Schoemaker (2005).

\section{Definitie van depressie}

Depressie behoort volgens de DSM-IV (APA, 2001) tot de groep van de zogenoemde stemmingsstoornissen. Iemand heeft een depressie wanneer hij of zij gedurende tenminste twee weken minstens één van de twee volgende kernsymptomen heeft:

- een zeer neerslachtige stemming gedurende het grootste deel van de dag, bijna elke dag;

- een ernstig verlies van interesse in alle of bijna alle activiteiten gedurende het grootste deel van de dag, bijna elke dag.

Daarnaast dienen er nog andere symptomen aanwezig te zijn:

- eetproblemen (heel veel of juist heel weinig eten) en veranderingen in het gewicht;

- slaapproblemen;

- geagiteerd en rusteloos zijn of juist geremd;

- vermoeidheid en verlies van energie;

- gevoelens van waardeloosheid of overmatige schuld;

- concentratieproblemen, vertraagd denken en besluiteloosheid;

- terugkerende gedachten aan dood of zelfdoding.

Er is sprake van een depressieve stoornis wanneer tenminste vijf symptomen tegelijk aanwezig zijn, inclusief neerslachtige stemming en/of interesseverlies. Andere termen voor een depressieve stoornis zijn 'depressie in engere zin' en 'major depression'. In 
dit rapport gebruiken we de term 'depressie' wanneer we het over een depressieve stoornis hebben.

Als er twee tot vier symptomen van depressie aanwezig zijn die gezamenlijk niet beantwoorden aan de diagnostische criteria van een depressie, spreekt men van een subklinische depressie (ook wel 'minor depression' genoemd). Vanuit preventieperspectief is subklinische depressie van belang omdat zij vaak optreedt als voorloper van een klinische depressie.

\section{Duur en beloop van depressie}

Een episode van depressie duurt gemiddeld ongeveer zes maanden (Kruijshaar et al., 2005). De duur varieert nogal: de helft van de episodes is korter dan drie maanden en gaat zonder behandeling vanzelf weer over, terwijl één op de vijf episodes langer dan twee jaar duurt. Bij jongeren duurt een eerste depressie gemiddeld iets langer dan een half jaar (Kessler et al., 2001; Lewinsohn, 1994). Bij ouderen duurt een depressie vaak langer: 43\% van de depressies bij ouderen zijn langdurig: tien maanden of langer, en $34 \%$ wordt zelfs chronisch (Geerlings et al., 2000).

Depressie onder de algemene bevolking heeft, als de persoon niet wordt behandeld, een wisselend beloop (Brilman et al., 1992; Schoemaker et al., 2002; Smit et al., 2003; Spijker, 2002). De kans op terugval is groot: bij 40\% van de mensen met depressie keert de stoornis binnen twee jaar terug. Ook na herstel, bijvoorbeeld ten gevolge van een geslaagde behandeling, kunnen bij patiënten symptomen van een depressie blijven voortbestaan. Deze symptomen zijn voorspellers van terugval. Mensen met een depressie brengen gemiddeld circa $20 \%$ van hun leven door in depressieve episodes, 70 tot 80\% ervaart een herhaling en bij 15 tot 20\% krijgt de depressie een chronisch beloop (Angst, 1992; Kruijshaar, 2005).

\section{Doelgroepen voor preventie van depressie}

Er bestaat niet één oorzaak van depressie; het gaat altijd om een combinatie van elkaar beïnvloedende determinanten. De determinanten zoals die naar voren komen in epidemiologisch onderzoek zijn elders uitgebreid beschreven (Maas \& Jansen, 2000; Schoemaker \& De Ruiter, 2005, Schoemaker et al., 2002). Hun onderlinge verbanden worden weergegeven in het Dynamisch Stress-kwetsbaarheidsmodel (zie Maas \& Jansen, 2000; Witte, 2004).

In deze paragraaf gaan we niet uitgebreid in op de afzonderlijke determinanten. We richten ons hier op concrete doelgroepen voor preventie. In deze doelgroepen komen meestal meerdere determinanten samen. Zoals beschreven in hoofdstuk 2 hanteren we bij het beschrijven van de doelgroepen de indeling in geïndiceerde, selectieve en universele preventie. Deze indeling moet niet al te strikt worden opgevat; verschillende doelgroepen zijn met verschillende vormen van preventie te benaderen. Daarnaast overlappen doelgroepen elkaar gedeeltelijk, waardoor sprake is van een extra hoog risico (Schoevers et al., 2006; Smit et al., 2006a). 


\section{Geïndiceerde preventie}

De doelgroep voor geïndiceerde preventie bestaat uit mensen met depressiviteitsklachten, die (nog) niet voldoen aan de diagnose depressie. Zij lopen immers een sterk verhoogde kans om depressie te ontwikkelen (Hermens et al., 2004). Mensen met depressiviteitsklachten die daarnaast ook behoren tot een van de onderstaande doelgroepen voor selectieve of universele preventie lopen een sterk verhoogde kans op depressie.

\section{Selectieve preventie}

Voor selectieve preventie zijn in de praktijk de volgende twee specifieke doelgroepen van belang:

- Kinderen van ouders met een psychische stoornis. Zij hebben bijna driemaal zoveel kans om een depressie of een andere psychische stoornis te krijgen als kinderen van andere ouders (Beardslee et al., 2003). Dit komt allereerst door een genetisch bepaalde kwetsbaarheid. Daarnaast hebben deze kinderen echter ook te kampen met extra stress door de problemen die een psychisch ongezonde ouder met zich meebrengt. Bovendien zijn ze in sociaal opzicht extra kwetsbaar omdat de psychische problemen van de ouders hoogstwaarschijnlijk ook zullen doorwerken op de opvoeding van deze kinderen.

- Mensen met een chronische ziekte en hun partners. Mensen met een lichamelijke aandoening hebben ongeveer anderhalf keer zoveel kans op een psychische stoornis dan anderen (Verdurmen et al., 2006) Ook ouderen die zorgen voor een zieke partner lopen een verhoogde kans. Tot slot kan het overlijden van een (zieke) partner een levensgebeurtenis zijn die de kans op depressie verhoogt (Onrust et al., 2006).

\section{Universele preventie}

Voor universele preventie kunnen enkele bredere doelgroepen worden onderscheiden.

- Volwassen vrouwen. Depressie komt bij vrouwen ongeveer tweemaal zo vaak voor als bij mannen (Schoemaker et al., 2002). Bovendien is de prevalentie van depressie bij volwassenen het hoogst.

- Jongeren. Jongeren zijn op basis van hun leeftijd vooral een geschikte doelgroep voor universele preventie van depressie. Een inadequate manier van omgaan met stressvolle situaties (coping) is een risicofactor voor het ontwikkelen van een depressie. Door jongeren in een vroeg stadium sociaal-emotionele vaardigheden eigen te maken om adequaat om te gaan met stressvolle situaties, zijn ze in hun leven mogelijk beter beschermd tegen het ontwikkelen van psychische problemen, waaronder depressie (Hermanns et al., 2005).

- Ouderen zijn een belangrijke doelgroep voor depressie, omdat daarbij meerdere determinanten voor depressie samenkomen: chronische ziekte, verlies van partner, zingevingsproblemen, minder sociale contacten / sociale steun, eenzaamheid (Smit et al., 2006a). Specifieke groepen ouderen met een verhoogd risico zijn ouderen in verzorgingstehuizen (Cuijpers \& Van Lammeren, 1999) en ouderen die zorgen voor een partner met dementie of Parkinson (Katz et al., 1994). 
- Allochtonen. Ook bij deze groep komen meerdere determinanten samen. Allochtonen hebben vaker dan gemiddeld slechte sociaal-economische omstandigheden, en hebben vaak een verhoogd risico op gebrek aan sociale steun (Haastrecht \& Verweij, 2005; Maas \& Jansen, 2000).

- Mensen met een lage sociaal-economische status. Deze mensen hebben vaak te kampen met een combinatie van determinanten, zoals stressvolle (sociaal-economische) levensomstandigheden of een ongezonde leefstijl. Specifieke groepen van mensen met een lage sociaal-economische status zijn bijvoorbeeld terug te vinden in achterstandswijken of onder langdurig werklozen. Ook vluchtelingen verkeren vaak in slechte sociaal-economische omstandigheden. Zij lopen extra risico op een depressieve stoornis omdat bij hen meestal ook andere risicofactoren aanwezig zijn, zoals een geschiedenis van traumatische of stressvolle ervaringen en een gebrek aan sociale steun (Maas \& Jansen, 2000; Verweij \& Ten Dam, 2006).

- Mensen met weinig sociale steun. Specifieke groepen die vaak te kampen hebben met een gebrek aan sociale steun zijn bijvoorbeeld ouderen en weduwen (Schoevers et al., 2006).

\subsection{Omvang, ernst en gevolgen van depressie}

\section{Jaarprevalentie}

Per jaar lijdt naar schatting 5,4\% van de inwoners van Nederland aan depressie (tabel 3.1). Het gaat dan om ongeveer 737 duizend mensen. Deze cijfers komen overeen met die in andere westerse landen. Onder jongeren komt depressie in verhouding iets minder voor: ongeveer 3,8\% van de jongeren tussen 13 en 17 jaar (oftewel 37.400 jongeren) lijdt per jaar naar eigen zeggen aan depressie (Verhulst et al., 1997). Bij volwassenen tussen 18 en 65 jaar komt depressie meer voor dan bij jongeren. Ongeveer één op de 18 volwassenen (5,7\%) lijdt per jaar aan depressie (Bijl et al., 1997a). Dat zijn bijna 589 duizend mensen. Bij ouderen komt depressie iets minder vaak voor dan bij volwassenen jonger dan 65 jaar. Per jaar lijdt ongeveer één op de twintig ouderen $(5,0 \%)$ aan depressie (Beekman et al., 1997b; Schoemaker et al., 2005). Dit zijn ruim 111 duizend mensen.

\section{Incidentie}

Per jaar ontwikkelt zo'n 2,8\% van de volwassen bevolking voor het eerst een depressie (Bijl et al., 2002). Dat zijn, doorgerekend naar 2003, in totaal bijna 289 duizend volwassenen. Incidentiecijfers voor jongeren en ouderen ontbreken. Wel is er recent Amerikaans onderzoek, waaruit blijkt dat 15\% van de mensen die ooit in hun leven een depressie hebben gehad, dit voor het eerst krijgt tussen het $14^{\mathrm{e}}$ en $19^{\mathrm{e}}$ levensjaar; $10 \%$ krijgt dit vóór het $14^{\mathrm{e}}$ jaar. Slechts $5 \%$ van de mensen met een depressie krijgt dit pas na zijn $64^{\mathrm{e}}$ voor het eerst (Kessler et al., 2005). Als we deze cijfers extrapoleren naar Nederland gaat het voor de hele Nederlandse bevolking om ongeveer 359 duizend nieuwe gevallen van depressie per jaar (tabel 3.1; voor een uitleg van deze extrapolatie zie bijlage 2). 


\section{Ziektelast}

De wegingsfactor voor de ziektelast van depressie is voor jongeren (13 t/m17 jaar), volwassenen (18 t/m 64 jaar) en ouderen (65+ jaar) dezelfde: 0,46 (Kruijshaar et al., 2005). Daarmee staat depressie in totaal voor 157.400 ziektejaarequivalenten (voor een uitleg van de berekening zie bijlage 2).

Depressie vergroot de kans op voortijdig overlijden (Schoemaker et al., 2002). Hierover zijn geen Nederlandse cijfers bekend, maar uit een meta-analyse blijkt dat mensen met een depressie bijna twee maal zoveel kans lopen om binnen een bepaalde periode te overlijden dan niet-depressieve mensen (Cuijpers \& Smit, 2002). Dit is echter niet terug te vinden in de berekening van het aantal verloren levensjaren door depressie van het Centraal Bureau voor de Statistiek (CBS). Volgens het CBS gaat het om slechts 308 jaren (De Hollander et al., 2006); dit is waarschijnlijk een onderschatting (tekstblok 1.1).

Uitgaande van dit CBS-cijfer komt het totaal aantal DALY's voor depressie op minimaal 157.700. De ziektelast voor het aantal nieuwe gevallen van depressie bedroeg ruim 82.400 DALY's (tabel 3.1).

\section{Zorggebruik}

Van de volwassenen met depressie maakte in 1996 ongeveer twee derde in een gegeven jaar gebruik van enigerlei zorg. Meer dan de helft van hen bezocht de eerstelijn, ongeveer een derde bezocht de ambulante GGZ. Slechts $2 \%$ van de volwassenen met depressie werd opgenomen in de GGZ (Bijl \& Ravelli, 1998). Dergelijke zorggebruikcijfers over jongeren en ouderen zijn niet beschikbaar; waarschijnlijk zijn ze lager, omdat depressie bij deze groepen minder snel wordt herkend. Het is wel bekend welk deel van de ouderen door de huisarts behandeld is met medicatie die met depressie te maken kan hebben: 19\% is het half jaar voorafgaand aan de studie behandeld met antidepressiva en 39\% met benzodiazepines. Vijftien procent van de ouderen heeft in het half jaar voorafgaand aan de studie een psychiater gezien, 16\% een maatschappelijk werker en 10\% heeft een RIAGG bezocht (Beekman et al., 1997).

\section{Zorgkosten}

De bronnen van de Kosten van Ziekten-studie (Slobbe et al., 2006) laten een uitsplitsing van depressie en dysthymie helaas niet toe. Hieronder geven we daarom de cijfers voor beide stoornissen samen. In 2003 werd ongeveer 660 miljoen euro uitgegeven aan zorgkosten samenhangend met depressie en dysthymie (tabel 3.1). Dat was ongeveer $1,2 \%$ van het totaal van 57,5 miljard aan zorgkosten, en ongeveer $5,2 \%$ van de 12,6 miljard euro die werd besteed aan de zorg voor mensen met psychische stoornissen (inclusief verstandelijke handicap). Twee derde van de zorgkosten voor depressie en dysthymie werd besteed aan vrouwen ( 447 miljoen euro) en een derde aan mannen (213 miljoen euro).

Ongeveer 3\% van die 660 miljoen euro (ongeveer 20 miljoen euro) ging naar kinderen en jongeren tussen 0 en 19 jaar, waarvan veruit het grootste deel besteed werd aan jongeren 15 t/m 19 jaar (ruim 16 miljoen euro). Het overgrote deel - 457 miljoen 
euro - werd besteed aan de zorg voor volwassenen tussen 20 en 64 jaar. Ongeveer 184 miljoen euro ging naar de zorg voor ouderen met depressie. Qua kosten was de leeftijdsgroep 20 tot 44 jaar flink oververtegenwoordigd. Ongeveer 236 miljoen euro (ruim 35\% van de totale zorgkosten voor depressie en dysthymie) komt terecht in deze leeftijdgroep: 159 miljoen voor de vrouwen en 78 miljoen voor de mannen.

Voor incidente kosten hebben we gebruik gemaakt van een andere kosten-studie, die van Nemesis (Smit et al., in druk-b). Deze studie geeft onder andere een schatting van de directe zorgkosten voor volwassenen bij depressie exclusief dysthymie (tekstblok 2.1). De directe zorgkosten voor het aantal nieuwe gevallen van depressie bij volwassenen bedroegen in 2003 ruim 124 miljoen euro (tabel 3.1).

\section{Ziekteverzuim en kosten van ziekteverzuim}

De aanwezigheid van depressie hangt - vooral bij mannen - samen met ziekteverzuim. Mannen met depressie verzuimen bijna twee maal zo vaak als mannen zonder depressie (Buist-Bouwman, 2005; Laitinen-Krispijn \& Bijl, 2002). Voor vrouwen is dit verschil niet significant. Onder de langdurig verzuimers komen stemmingsstoornissen drie keer zo vaak voor als onder werknemers die hooguit incidenteel een paar dagen verzuimen.

De jaarlijkse kosten van productieverlies als gevolg van ziekteverzuim door depressie zijn ongeveer anderhalf duizend euro per hoofd van de volwassen bevolking (Smit et al., in druk-b). Bij een aantal van zo'n 589 duizend volwassenen per jaar met een depressie is dit ongeveer 953 miljoen euro (tabel 3.1). De jaarlijkse kosten als gevolg van productieverliezen door ziekteverzuim bij de nieuwe gevallen van depressie bedroegen ruim 467 miljoen euro.

\section{Arbeidsongeschiktheid}

Van de 992 duizend mensen die in 2002 arbeidsongeschikt waren (WAO, WAZ en WAJONG) hadden ongeveer 53 duizend van de verzekeringsarts de diagnose depressieve episode gekregen; dat is $5 \%$ (UWV, 2002). Vrouwen zijn hierbij oververtegenwoordigd. Binnen de hoofdgroep 'psychische diagnoses' was ongeveer één op de zeven arbeidsongeschikten depressief. Het overgrote deel hiervan - 49 duizend - zat in de WAO, de rest zat in de WAZ en de WAJONG (bijlage 2). Driekwart van de mensen in de WAO (76\%) was volledig arbeidsongeschikt. Van de 108 duizend nieuwe arbeidsongeschikten in 2002 kregen ongeveer 10 duizend (9\%) de diagnose depressieve episode. Binnen de hoofdgroep psychische diagnoses nam depressie ook bij de WAO-instroom een zeer belangrijke plaats in: ongeveer 20\%. Het aantal arbeidsongeschikten met depressie nam in 2002 toe: de jaarlijkse instroom (10 duizend) was in 2002 twee keer zo hoog als de uitstroom (5 duizend).

\section{Omvang, ernst en gevolgen van depressie samengevat}

Jaarlijks zijn er bijna 740 duizend mensen met depressie; zij vertegenwoordigen ongeveer 158 duizend DALY's (tabel 3.1). De totale zorgkosten van depressie bedragen jaarlijks ruim 660 miljoen euro. Daarnaast genereren ze 953 miljoen euro aan kosten 
als gevolg van ziekteverzuim. Het aantal arbeidsongeschikten als gevolg van depressie was in 2002 zo'n 53 duizend. Het aantal nieuwe gevallen van depressie bedraagt jaarlijks naar schatting bijna 359 duizend mensen; zij vertegenwoordigen ongeveer 82 duizend DALY's. De zorgkosten voor nieuwe gevallen van depressie voor volwassenen bedragen jaarlijks zo'n 124 miljoen euro; daarnaast genereren deze volwassenen ruim 467 miljoen euro aan kosten als gevolg van ziekteverzuim. In hoeverre de omvang, ernst en gevolgen kunnen worden gereduceerd met behulp van preventie hangt af van de beschikbaarheid van effectieve interventies en het bereik daarvan. Dat is het onderwerp van de volgende paragrafen.

Tabel 3.1: Depressie: omvang, ernst en gevolgen per jaar.

\begin{tabular}{|c|c|c|c|c|}
\hline & Jongeren & Volwassenen & Ouderen & Totaal \\
\hline \multicolumn{5}{|l|}{ Prevalente gevallen } \\
\hline \multicolumn{5}{|l|}{ Omvang } \\
\hline \multicolumn{5}{|l|}{ Jaarprevalentie $^{\mathrm{a}}$} \\
\hline$\%$ & 3,8 & 5,7 & 5,0 & 5,4 \\
\hline aantal & 37.400 & 588.800 & 111.100 & 737.300 \\
\hline \multicolumn{5}{|l|}{ Ernst en gevolgen } \\
\hline \multicolumn{5}{|l|}{ Ziektelast $^{\text {a }}$} \\
\hline aantal DALY’s b & 7.900 & 125.900 & 23.900 & 157.700 \\
\hline \multicolumn{5}{|l|}{ Kosten (in mln euro) } \\
\hline zorgkosten $^{\mathrm{c}}$ & 19,5 & 456,6 & 184,3 & 660,4 \\
\hline & - & 953,3 & - & - \\
\hline Arbeidsongeschiktheid e & - & 53.000 & - & - \\
\hline \multicolumn{5}{|l|}{ Incidente gevallen } \\
\hline \multicolumn{5}{|l|}{ Omvang } \\
\hline \multicolumn{4}{|l|}{ Incidentie } & 358.500 \\
\hline \multicolumn{5}{|l|}{ Ernst en gevolgen } \\
\hline \multicolumn{5}{|l|}{ Ziektelast } \\
\hline \multicolumn{5}{|l|}{ Kosten } \\
\hline zorgkosten (in mln euro) g & - & 124,4 & - & - \\
\hline kosten door ziekteverzuim $\mathrm{g}$ & - & 467,4 & - & - \\
\hline
\end{tabular}

a Leeftijdsgroepen: 13-17 (Verhulst et al., 1997), 18-64 (Bijl et al., 1997) en 65+ (Beekman et al., 1997).

b Wegingsfactor voor depressie $=0,46$; ziekteduur $=6 \mathrm{mnd}$; zie voor een berekening tekstblok 1.1 .

c Leeftijdsgroepen: 0-19, 20-64, 65+ (Slobbe et al., 2006); inclusief dysthymie.

d Prevalent verzuim volwassenen 18-64 jaar (Smit et al., in druk-b).

e Prevalente gevallen, gebaseerd op gegevens uit 2002 (UWV, 2002).

f Incidentie afgeleid van lifetime prevalentie (Kessler et al., 2005), in relatie tot incidentiecijfers van Nemesis (Bijl et al., 2002); zie voor een berekening bijlage 2 .

Deze cijfers zijn hoger dan op grond van de prevalentie-aantallen verwacht zou worden.

g Verzuim volwassenen met incidente depressie, 18-64 (Smit et al., in druk-b). 


\subsection{Preventieve interventies voor depressie bij jongeren}

In deze paragraaf geven we een samenvatting van de in Nederland beschikbare preventieve interventies voor depressie bij jongeren. In paragraaf 3.3.1 komen de in Nederland beschikbare interventies aan bod. De interventies zijn ingedeeld in universele, selectieve en geïndiceerde preventie (paragraaf 2.3). Aan het eind van deze paragraaf staat een tabel met alle beschikbare interventies ter preventie van depressie bij jongeren (tabel 3.2). Paragraaf 3.3.2 beschrijft gezondheidseffecten van die interventies die in een gerandomiseerde studie geëvalueerd zijn, inclusief conclusies over de behaalbare gezondheidswinst. Voor een uitgebreide beschrijving van de in Nederland beschikbare interventies ter preventie van depressie bij jongeren verwijzen we naar bijlage 3. Voor een uitleg van de beoordeling op wetenschappelijke status en ontwikkelingsfase verwijzen we naar paragraaf 2.4 .

\subsubsection{In Nederland beschikbare interventies ter preventie van depressie bij jongeren}

\section{Universele preventie}

Universele interventies ter vermijding van depressie en gericht op jongeren hebben vaak een brede insteek, waarbij aandacht wordt besteed aan algemene sociale en emotionele vaardigheden om met problemen om te gaan. Uitgangspunt daarbij is dat het aanbrengen en versterken van deze vaardigheden bijdraagt aan het voorkomen van psychische klachten in algemene zin, dus ook van depressiviteitsklachten.

In het buitenland zijn diverse universele programma's gericht op preventie van depressie ontwikkeld en onderzocht. Deze programma's bestaan uit lessenseries op school over depressie en stemming. Behalve informatie over depressie komen daarin ook 'mood-management' technieken aan bod, waarvan bekend is dat ze in behandelingen effectief zijn. Er zijn diverse goed opgezette effectonderzoeken uitgevoerd om te onderzoeken of dergelijke programma's depressiviteitsklachten kunnen verminderen of toekomstige depressies kunnen voorkomen (Merry et al., 2004). De lesprogramma's blijken helaas nauwelijks effecten te hebben op het genezen of voorkómen van depressie, en we concluderen daarom dat deze interventies niet beschikken over wetenschappelijk bewezen effecten.

Naast specifiek op depressie gerichte universele schoolprogramma's zijn er ook programma's die niet specifiek op depressie zijn gericht maar die proberen algemene 'levensvaardigheden' te bevorderen. Deze programma's hebben de intentie om een breed scala aan problemen te beïnvloeden, waaronder depressie. Het effect op depressie is echter niet onderzocht. Gezien de kleine effecten van specifiek op depressie gerichte programma's lijkt het niet waarschijnlijk dat dergelijke brede programma's wel belangrijke effecten op bestaande of toekomstige depressies kunnen hebben. In Nederland beschikbare programma's ter bevordering van algemene levensvaardigheden zijn:

- 'Levensvaardigheden'. Dit is een lesprogramma ontwikkeld door de GGD Rotterdam en is onder andere gebaseerd op het programma 'Life skills' van de WHO. 
Het bestaat uit veertien lessen van 50 minuten en richt zich op alle leerlingen in de derde klas van het voortgezet onderwijs. Er zijn aanwijzingen (Gravesteijn, 2004) dat het programma effecten heeft op intermediaire uitkomstmaten, zoals zelfwaardering. Het effect op depressie is onbekend.

Ontwikkelingsfase: G. Wetenschappelijke status: *.

- Het lesprogramma 'Leefstijl' (Lions Clubs International \& Quest International, 1990). Dit lesprogramma richt zich op leerlingen tussen 12-18 jaar van het voortgezet onderwijs. In het buitenland is in beperkte mate onderzoek naar dit programma gedaan, maar het is niet bekend of het ook effecten heeft op depressie. Ontwikkelingsfase: G. Wetenschappelijke status: *.

\section{Selectieve preventie}

Een belangrijke risicogroep voor het ontwikkelen van psychische klachten, waaronder depressiviteits- en angstklachten, zijn kinderen van ouders met psychische en/of verslavingsproblemen (Bijl et al., 2001). In Nederland wordt vanuit de preventieve GGZ veel aandacht aan deze doelgroep besteed. Deze selectieve preventieprogramma's beschrijven we hieronder in het kort (Cuijpers et al., 2006).

- De interventie 'Kinderen van ouders met psychische problemen (KOPP)' (Van Sambeek et al., 2002; Bool et al., 2005; Trimbos-instituut, 2001) is een groepscursus voor pubers van wie de ouder(s) psychische of verslavingsproblemen hebben. Er bestaan twee versies: voor 12-15 jaar en voor 16+.

Ontwikkelingsfase: G. Wetenschappelijke status: *

- Voor kinderen van ouders met psychische problemen is er de 'Psycho-educatieve gezinsinterventie’ (Beardslee et al., 2003). Uit gerandomiseerd onderzoek (Beardslee et al., 2003) blijkt dat de interventie wel effecten heeft op risico- en beschermende factoren, maar niet op depressiviteitsklachten bij de kinderen.

Ontwikkelingsfase: G. Wetenschappelijke status: *.

\section{Geïndiceerde preventie}

De in Nederland beschikbare interventies gericht op preventie van depressie bij jongeren zijn de volgende:

- De groepscursus ‘Een stap op weg’ is gericht op jongeren van 14-18 jaar met milde depressiviteitsklachten en minimaal VMBO theoretische leergang (Pauw et al., 1999). Deze cursus is gebaseerd op de Amerikaanse 'Coping with depression course for adolescents' van Clarke et al. (1990). De interventie is afgeleid van cognitieve gedragstherapie en interpersoonlijke therapie. De groepscursus is in de Verenigde Staten effectief bevonden (Clarke et al., 1995; 2001), maar die interventies zijn wat uitvoeriger dan de Nederlandse varianten daarvan (zie paragraaf 3.3.2).

Ontwikkelingsfase: G. Wetenschappelijke status: **

- De groepscursus ‘Grip op je dip: zelf je somberheid overwinnen’ richt zich op jongeren tussen 16-25 jaar met depressiviteitsklachten (Voordouw et al., 2002a). Ook deze cursus is gebaseerd op de Amerikaanse 'Coping with depression course for adolescents' van Clarke et al. (1990), en evenals 'Een stap op weg' afgeleid van cognitieve gedragstherapie en interpersoonlijke therapie. Deze groepscursus is in de Verenigde Staten effectief bevonden (Clarke et al., 1995; 2001; zie paragraaf 
3.3.2). De Nederlandse bewerking van deze interventie bevat minder bijeenkomsten dan de Amerikaanse versie, en werd in een pilotstudie nader onderzocht. Er werd een significante afname van depressiviteitsklachten gevonden (Voordouw et al., 2002a), maar deze klachtenvermindering is niet vergeleken met herstel in een controlegroep, zodat de resultaten lastig te interpreteren zijn.

Ontwikkelingsfase: G. Wetenschappelijke status: ${ }^{* *}$.

- De internetcursus ‘Grip op je dip online’ (www.gripopjedip.nl; Van der Zanden et al., 2005) is een variant van de eerder beschreven groepscursus ‘Grip op je dip’. Deze variant wordt via het internet groepsgewijs aangeboden aan jongeren tussen 16 en 25 jaar met depressiviteitsklachten. De interventie werd in niet-experimenteel onderzoek geëvalueerd (Gerritsen, in voorbereiding; Van der Zanden et al., 2005) Ontwikkelingsfase: G. Wetenschappelijke status: **.

- De groepscursus 'Stemmingmakerij' (Ruiter, 1997) is gericht op jongeren tussen de 15 en 19 jaar met lichte depressiviteitsklachten. Door de cursus in schooltijd te geven wordt een relatief hoge drempel verlaagd. In Nederland werd de effectiviteit van de cursus in een quasi-experimentele studie onderzocht op effectiviteit. Deelname aan de cursus leidt tot minder depressiviteits- en andere psychische klachten. Verder ontstaat verbetering in schoolprestaties, sociale vaardigheden en zelfwaardering (Elling, 2004; Ruiter, 1997).

Ontwikkelingsfase: G. Wetenschappelijke status: **.

Een belangrijk knelpunt dat zich in de praktijk voordoet bij jongeren is dat zij moeilijk te bereiken zijn met groepscursussen. Daar zijn twee oplossingen voor ontwikkeld. Ten eerste wordt op sommige plaatsen systematisch gescreend op depressie, zodat zo veel mogelijk leerlingen met depressiviteitsklachten opgespoord kunnen worden. Een meta-analyse (Cuijpers et al., 2006) van internationale gerandomiseerde studies naar de effecten van screening en vroege interventies gericht op depressie bij kinderen en adolescenten liet middelgrote effecten zien. Uit deze meta-analyse komt tevens naar voren dat van elke duizend kinderen die gescreend worden, er gemiddeld 72 de interventie krijgen aangeboden, waarvan er vervolgens 32 een positieve uitkomst hebben. Het aantal kinderen dat gescreend moet worden om één positieve uitkomst te genereren is daarmee 31. Ten tweede zijn er van de groepsinterventies internetversies gemaakt, zoals de bovengenoemde internetcursus ‘Grip op je dip - online’.

\subsubsection{Gezondheidseffecten van preventie van depressie bij jongeren}

Van de bovenbeschreven interventies zijn er twee onderzocht in een - buitenlandse - gerandomiseerde studie: ‘Een stap op weg’ en ‘Grip op je Dip’. Beide interventies zijn gebaseerd op interventies van Clarke en collega's in de Verenigde Staten: 'The Adolescent coping with stress course' (Clarke et al., 1995) en de 'The Adolescent coping with depression course' (Clarke et al., 2001). De interventies richten zich op het vergroten van inzicht in de eigen klachten en het leren van vaardigheden om hier beter mee om te gaan bij jongeren van 13 tot 18 jaar met milde depressiviteitsklachten. 
Tabel 3.2: Overzicht van in Nederland beschikbare interventies ter preventie van depressie bij jongeren

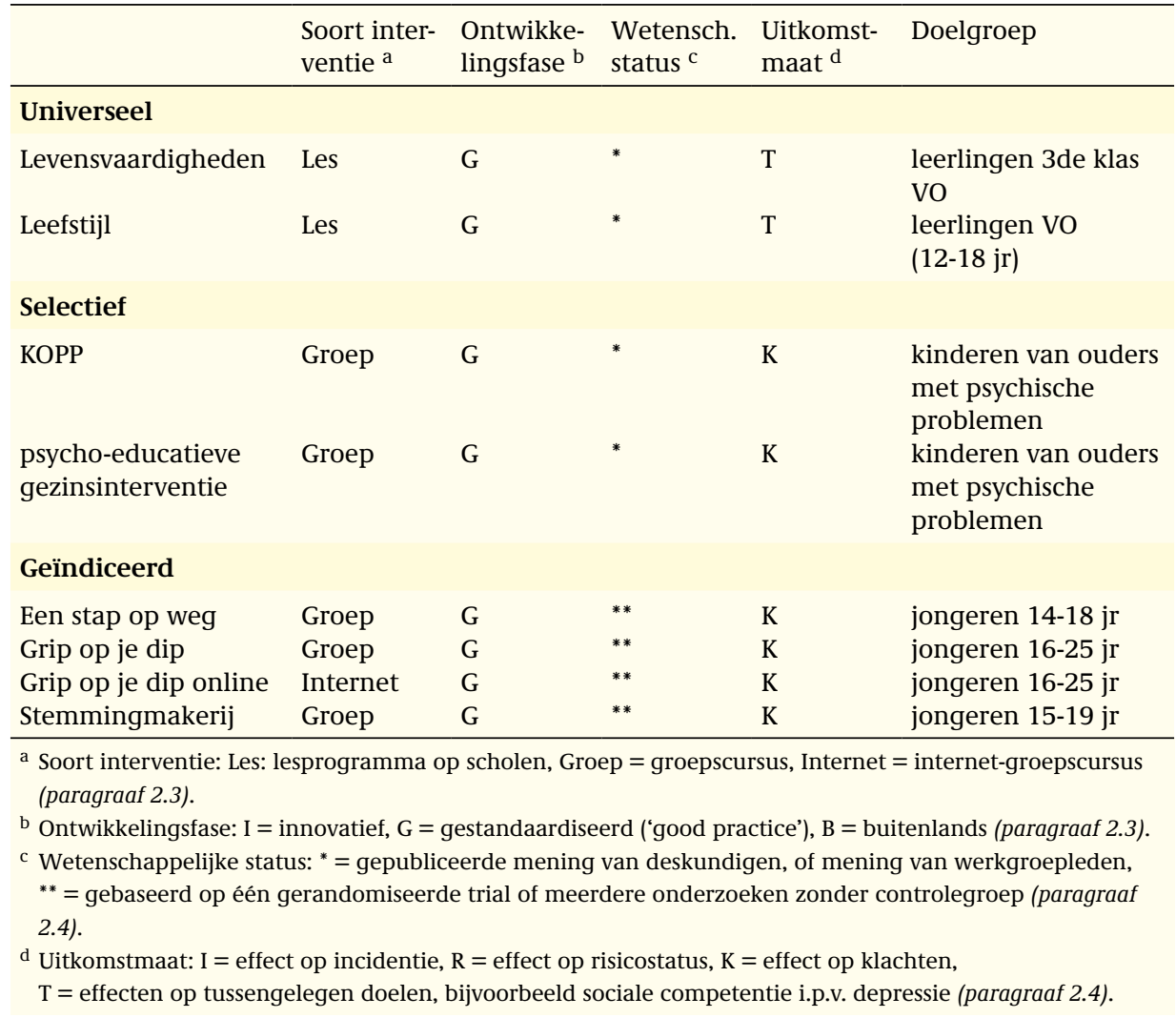

We bespreken de Amerikaanse gerandomiseerde studies om iets te kunnen zeggen over de haalbare gezondheidswinst met dit type interventie.

\section{The Adolescent Coping With Stress Course}

In het betreffende effectonderzoek (Clarke et al., 1995) werden 1.652 scholieren van drie scholen gescreend met de ‘Centre of Epidemiology Scale of Depression' (CES-D) op depressiviteitsklachten. Honderdvijftig leerlingen die hoog scoorden op deze vragenlijst en bovendien bereid waren om aan het onderzoek deel te nemen, werden willekeurig toegewezen aan de experimentele conditie (de interventie) en aan de controleconditie (gangbare zorg). Na twaalf maanden werd een vergelijking gemaakt tussen beide onderzoeksgroepen. Daarbij werd gekeken naar het percentage leerlingen met een depressieve stoornis. De data zijn weergegeven in tabel 3.3. Van de 76 deelnemers aan de interventie kregen 11 de stoornis (14\%) tegen 19 uit de 74 (26\%) in de controleconditie. Het risicoverschil is daarmee $26-14=11 \%$, ten gunste van de interventie. Het relatief risico is $0,14 / 0,26=0,56$ : onder invloed van de interventie wordt het risico op het krijgen van een depressieve stoornis teruggebracht tot $56 \%$ ten opzichte van het risico in de controlegroep. Ten slotte, de numbers needed to be treated (NNT) is gelijk aan 
1 / RV = 8,9: voor elke negen personen die deelnemen aan de interventie wordt één geval van depressie vermeden. Dit zegt dus iets over de efficiëntie van de interventie.

Tabel 3.3: Effectiviteit van de 'The adolescent coping with stress course' op de incidentie van depressie ${ }^{a}$.

\begin{tabular}{|c|c|c|c|c|}
\hline & & & $\begin{array}{l}\text { Interventiegroep } \\
\qquad(\mathrm{n}=76)\end{array}$ & $\begin{array}{c}\text { Controlegroep } \\
(\mathrm{n}=74)\end{array}$ \\
\hline Kreeg stoornis & & & 11 & 19 \\
\hline Bleef stoornisvrij & & & 65 & 55 \\
\hline \multirow[t]{2}{*}{ Risico op de stoornis } & & & 0,14 & 0,26 \\
\hline & & $95 \% \mathrm{BI}$ & & \\
\hline Risicoverschil (RV) & 0,11 & $(-0,02 \sim 0,24)$ & & \\
\hline Relatief risico (RR) & 0,56 & $(0,29 \sim 1,10)$ & & \\
\hline NNT & 8,9 & & & \\
\hline
\end{tabular}

$\chi^{2}=2,94, \mathrm{p}=0,04$ (1-zijdig)

${ }^{a}$ Clarke et al., 1995; voor een uitleg van deze tabel zie tekstblok 2.3.

Statistisch zijn de gevonden effecten niet significant ( $\mathrm{p}=0$ 0,04, 1-zijdig). Clarke et al hebben bewust gekozen voor een 1-zijdige toets, omdat zij geïnteresseerd waren in de meerwaarde van de interventie bovenop het effect van gangbare zorg. Extrapolatie van deze studie naar Nederland is alleen geldig wanneer de cursus hier op dezelfde wijze wordt uitgevoerd. Het is echter bekend dat de Nederlandse versie ingekort is, waardoor de resultaten niet zonder meer geëxtrapoleerd kunnen worden naar de Nederlandse versie.

\section{The Adolescent Coping With Depression Course}

De tweede studie (Clarke et al., 2001) naar dezelfde interventie had een vergelijkbare opzet als de eerste studie, maar de respondenten werden hier geworven via een grote gezondheidsinstelling. Als eerste stap in de werving werden volwassenen geselecteerd uit een patiëntenbestand wanneer zij antidepressiva gebruikten. Via deze volwassenen met een depressieve stoornis werden adolescente kinderen geworven die wel depressiviteitsklachten hadden, maar geen stoornis. Het idee hierbij was dat zo een groep adolescenten samengesteld wordt met een ultrahoog risico op depressie. In totaal werden 94 adolescenten geworven voor het onderzoek, waarvan 45 werden toegewezen aan de experimentele conditie (de cursus) en 49 aan de controleconditie (gangbare zorg). Na 24 maanden werd het voorkomen van een depressieve stoornis tussen beide condities vergeleken. Het effect van de interventie op de incidentie van depressie was statistisch significant en klinisch substantieel: in het voordeel van de interventie ontstaat een risicoverschil van $20 \%$ (tabel 3.4). In de groep die de interventie ontving werd bij $69 \%$ het ontstaan van een depressie vermeden. De NNT wijst er op dat circa vijf adolescenten de interventie moet ontvangen om bij één van hen het ontstaan van een depressie te vermijden in een tijdsperiode van twee jaar. 
Tabel 3.4: Effectiviteit van de 'The Adolescent coping With Depression Course' op de incidentie van depressie ${ }^{a}$.

\begin{tabular}{lccc}
\hline & & $\begin{array}{c}\text { Interventiegroep } \\
(\mathrm{n}=45)\end{array}$ & $\begin{array}{c}\text { Controlegroep } \\
(\mathrm{n}=49)\end{array}$ \\
\hline Kreeg stoornis & & 4 & 14 \\
Bleef stoornisvrij & & 41 & 35 \\
Risico op de stoornis & & 0,09 & 0,29 \\
& & & \\
Risicoverschil (RV) & 0,20 & $(0,05 \sim 0,35)$ & \\
Relatief risico (RR) & 0,31 & $(0,11 \sim 0,88)$ & \\
NNT & 5,1 & & \\
\hline
\end{tabular}

$\chi^{2}=5,87 ; p=0,02$

${ }^{a}$ Clarke et al., 2001; voor een uitleg van deze tabel zie tekstblok 2.3.

Op basis van hetzelfde onderzoek is bovendien de kosten-effectiviteit van de cursus berekend (Lynch et al., 2005). Lynch en collega's beschouwden zowel interventiekosten als overige medische kosten die gemaakt worden bij andere zorgaanbieders, en kosten van patiënten en hun familieleden. Ze beschouwden geen productieverliezen, wellicht omdat het gaat om een groep jongeren. Zij komen tot de conclusie dat de interventie geassocieerd is met gemiddeld US\$ 9.275 per voor kwaliteit van leven gecorrigeerd levensjaar (QALY). Omgerekend komt dit neer op € 8.533 per QALY. Ook de uitkomsten van deze studie kunnen alleen veilig naar Nederland gegeneraliseerd worden wanneer hier dezelfde aanpak wordt gevolgd. Dat is echter alleen bij benadering het geval, zodat de uitkomsten met enige terughoudendheid geïnterpreteerd dienen te worden voor de Nederlandse versie.

\section{Te behalen gezondheidswinst op bevolkingsniveau}

Uit het voorgaande kan geconcludeerd worden dat er twee vermoedelijk effectieve en doelmatige interventies beschikbaar zijn voor de geïndiceerde preventie van depressie bij jongeren: ‘Een stap op weg’ en 'Grip op je dip'. Beide groepscursussen zijn gebaseerd op de Amerikaanse versie van Clarke et al. (1990) en in een buitenlandse studie effectief gebleken in het verminderen van de incidentie van depressie.

Voor het berekenen van de haalbare gezondheidswinst met deze interventies op bevolkingsniveau maken we enkele aannamen. Het risicoverschil van de Nederlandse interventies houdt wellicht het midden tussen de $11 \%$ (Clarke et al., 1995) en $20 \%$ (Clarke et al., 2001), zeg 15\%. Over het bereik van de Nederlandse interventies is weinig met zekerheid te zeggen. Voor het bereik van de interventie kiezen we twee scenario's: $25 \%$ en $100 \%$ van de doelgroep van de 50.900 jongeren die jaarlijks voor het eerst in hun leven een depressieve stoornis krijgen (hoofdstuk 2).

Uitgaande van een risicoreductie van 15\% wordt bij ruim 1.900 jongeren een depressieve stoornis vermeden (theoretisch maximaal \pm 7.600 jongeren). Uitgaande van een gemiddelde duur van een depressieve episode van zes maanden en bij een wegingsfactor van 0,46 voor de ziektelast van elk geval van depressie worden hiermee jaarlijks zo'n 440 (theoretisch maximaal \pm 1.800 ) DALY's gewonnen (tabel 3.14). 


\subsection{Preventieve interventies voor depressie bij volwassenen}

In deze paragraaf geven we een samenvatting van de in Nederland beschikbare preventieve interventies voor depressie bij volwassenen. In paragraaf 3.4.1 komen de in Nederland beschikbare interventies aan bod. De interventies zijn ingedeeld in universele, selectieve en geïndiceerde preventie (zie hoofdstuk 2). Aan het eind van deze paragraaf staat een tabel met alle beschikbare interventies ter preventie van depressie bij volwassenen (tabel 3.5). Paragraaf 3.4.2 beschrijft gezondheidseffecten van die interventies die in een gerandomiseerde studie geëvalueerd zijn, inclusief conclusies over de te behalen gezondheidswinst. Voor een uitgebreide beschrijving van de in Nederland beschikbare interventies ter preventie van depressie bij volwassenen verwijzen we naar bijlage 3. Voor een uitleg van de beoordeling op wetenschappelijke status en ontwikkelingsfase verwijzen we naar paragraaf 2.4 .

\subsubsection{In Nederland beschikbare interventies ter preventie van depressie bij volwassenen}

\section{Universele preventie}

Er zijn in Nederland geen interventies beschikbaar voor universele preventie van volwassenen.

\section{Selectieve preventie}

Er zijn vele selectieve interventies ter preventie van depressie bij volwassenen ontwikkeld. Het valt buiten het bestek van dit rapport om deze interventies uitgebreid te beschrijven en we beperken ons tot uitsluitend de interventies die via de GGZ Preventieafdelingen worden aangeboden (zie paragraaf 2.3).

- De groepscursus 'Leven met een chronische ziekte' is beschikbaar voor volwassenen met een chronische ziekte die daarom een verhoogd risico lopen op een depressie (Cuijpers \& Van Osch, 2004; Voordouw et al., 2005). Buitenlands onderzoek laat zien dat deze interventie effect heeft op het ontstaan van depressie (Kühner, 2003). In Nederland werd een quasi-experimenteel onderzoek uitgevoerd (Voordouw et al., 2005) waarin een kleine maar statistisch significante afname in depressiviteitsklachten werd aangetroffen.

Ontwikkelingsfase: G. Wetenschappelijke status: **.

- De groepscursus 'Verlies en dan verder' is een interventie voor weduwen (Benthem et al., 1994; paragraaf 3.5). Hoewel een groot deel van de deelnemers aan deze interventies 55 jaar of ouder is, zijn er ook jongere volwassenen die hieraan deelnemen.

Ontwikkelingsfase: G. Wetenschappelijke status: ${ }^{* *}$.

\section{Geïndiceerde preventie}

Voor volwassenen met depressiviteitsklachten zijn er diverse interventies beschikbaar. In een aantal interventies wordt gebruik gemaakt van de combinatie van het stimuleren van fysieke inspanning (joggen, bewegen) en het geven van psycho-educatie. 
Blijkens vele meta-analyses is bekend dat fysieke inspanning gunstige effecten heeft op depressie en angststoornissen (Arent \& Landers, 1999; Arent, 2000; Callaghan 2004; Fox, 1999; Jorm et al., 2002; Petruzzelo et al., 1991). In het buitenland zijn diverse goed opgezette effectstudies uitgevoerd naar de effecten van bewegingsinterventies. In een meta-analyse van veertien gerandomiseerde effectstudies werd gevonden dat 'bewegingsinterventies' effectief zijn met een gestandaardiseerde effectgrootte van 1,10 (95\% betrouwbaarheidsinterval: 1,5 tot 0,6 ), wat vergelijkbaar is met de effecten van cognitieve therapie (Lawlor \& Hopker, 2001).

In Nederland zijn de volgende geïndiceerde interventies ter preventie van depressie bij volwassenen beschikbaar:

- De groepscursus 'In de put, uit de put' voor volwassenen (Cuijpers, 2004; Voordouw et al., 2002b) is gebaseerd op de door Lewinsohn en collega's ontwikkelde cursus 'Coping with depression' (1984). Er is in Nederland een gerandomiseerde studie uitgevoerd met positieve effecten en er bestaat een meta-analyse over meerdere trials van deze interventie (Cuijpers et al., aangeboden ter publicatie; zie paragraaf 3.4.2).

Ontwikkelingsfase: G. Wetenschappelijke status: ${ }^{* * *}$.

- De zelfhulpversie van 'In de put, uit de put' met minimale begeleiding is bedoeld voor volwassen huisartspatiënten met een subklinisch beeld van depressie. Er is in Nederland een gerandomiseerde studie uitgevoerd met positieve effecten op de incidentie van depressie (Willemse et al., 2004b; paragraaf 3.4.2).

Ontwikkelingsfase: G. Wetenschappelijke status: ${ }^{*}$.

- De interventie 'Liever bewegen dan moe' (Parnassia, 2005) richt zich op vrouwen uit sociaal-economische achterstandsgroepen met lichte depressiviteitsklachten (20-55 jaar). Het doel van de interventie is door lichaamsbeweging ook geestelijk weer in beweging te komen en de vrouwen te stimuleren om te blijven bewegen, ook na afloop van het programma. Diverse meta-analyses hebben effect van bewegen op depressiviteitsklachten aangetoond (Arent \& Landers, 1999; Arent, 2000; Callaghan 2004; Fox, 1999; Jorm et al., 2002; Petruzzelo et al., 1991). Het is echter niet bekend of deze bevindingen naar achterstandsgroepen gegeneraliseerd kunnen worden. Ontwikkelingsfase: G. Wetenschappelijke status: **.

- De begeleide internetcursus 'Alles onder controle' Cuijpers (2004c) is bedoeld voor mensen die last hebben van depressiviteitsklachten, angsten, spanningen en werkstress. Het doel van de interventie is een betere greep op het eigen leven te krijgen door problemen die verantwoordelijk zijn voor de klachten planmatig aan te pakken. De interventie wordt via het internet aangeboden en op afstand, met e-mails, begeleid door psychologen. Gerandomiseerd onderzoek (Van Straten et al., in voorbereiding), laat positieve effecten zien (paragraaf 3.4.2). Ontwikkelingsfase: I. Wetenschappelijke status: ${ }^{* *}$.

- De cursus ‘Bewegen zonder zorgen' (Gelissen et al., 2006) is eveneens ontwikkeld voor vrouwen uit sociaal-economische achterstandsgroepen. Diverse meta-analyses hebben een afname van depressiviteitsklachten aangetoond (Arent \& Landers, 1999; Arent, 2000; Callaghan, 2004; Fox, 1999; Jorm et al., 2002; Petruzzelo et al., 1991). Het is echter niet bekend of deze bevindingen naar achterstandsgroepen 
Tabel 3.5: Overzicht van in Nederland beschikbare interventies ter preventie van depressie bij volwassenen.

\begin{tabular}{|c|c|c|c|c|c|}
\hline & $\begin{array}{l}\text { Soort inter- } \\
\text { ventie }^{\mathrm{a}}\end{array}$ & $\begin{array}{l}\text { Ontwikke- } \\
\text { lingsfase }{ }^{\mathrm{b}}\end{array}$ & $\begin{array}{l}\text { Wetensch. } \\
\text { status }^{c}\end{array}$ & $\begin{array}{l}\text { Uitkomst- } \\
\text { maat }^{d}\end{array}$ & Doelgroep \\
\hline \multicolumn{6}{|l|}{ Universeel } \\
\hline \multicolumn{6}{|l|}{-} \\
\hline \multicolumn{6}{|l|}{ Selectief } \\
\hline $\begin{array}{l}\text { Leven met een } \\
\text { chronische ziekte }\end{array}$ & Groep & G & ** & $\mathrm{K}$ & $\begin{array}{l}\text { volwassenen met } \\
\text { chronische ziekte }\end{array}$ \\
\hline Verlies en dan verder & Groep & G & ** & K & $\begin{array}{l}\text { volwassen en oudere } \\
\text { weduwen }\end{array}$ \\
\hline \multicolumn{6}{|l|}{ Geïndiceerd } \\
\hline $\begin{array}{l}\text { In de put, uit de put } \\
\text { volwassenen }\end{array}$ & Groep & G & $* * *$ & I & Volwassenen \\
\hline $\begin{array}{l}\text { In de put, uit de put, } \\
\text { zelfhulp }\end{array}$ & Zelfhulp & G & *** & I & $\begin{array}{l}\text { volwassen } \\
\text { huisartspatiënten }\end{array}$ \\
\hline $\begin{array}{l}\text { Liever bewegen dan } \\
\text { moe }\end{array}$ & Groep & G & $* *$ & K & $\begin{array}{l}\text { vrouwen met lage } \\
\text { SES }\end{array}$ \\
\hline Alles onder controle & Internet & I & *** & K & $\begin{array}{l}\text { volwassenen met } \\
\text { psychische klachten }\end{array}$ \\
\hline $\begin{array}{l}\text { Bewegen zonder } \\
\text { zorgen }\end{array}$ & Groep & I & ** & K & $\begin{array}{l}\text { vrouwen met lage } \\
\text { SES }\end{array}$ \\
\hline $\begin{array}{l}\text { Lichte dagen, } \\
\text { donkere dagen }\end{array}$ & Groep & G & * & - & $\begin{array}{l}\text { Turkse en } \\
\text { Marokkaanse } \\
\text { volwassenen }\end{array}$ \\
\hline Kleur je leven & Internet & I & * & $\mathrm{K}$ & volwassenen \\
\hline
\end{tabular}

a Soort interventie: Les: lesprogramma op scholen, Groep = groepscursus,

Zelfhulp = schriftelijke zelfhulpcursus, Internet $=$ internet-zelfhulpcursus (paragraaf 2.3).

b Ontwikkelingsfase: I= innovatief, $\mathrm{G}=$ gestandaardiseerd (paragraaf 2.3).

c Wetenschappelijke status: * = gepubliceerde mening van deskundigen, of mening van werkgroepleden, ${ }^{* *}=$ gebaseerd op één gerandomiseerd onderzoek of op meerdere onderzoeken zonder controlegroep,

*** = gebaseerd op tenminste twee gerandomiseerde onderzoeken of ander vergelijkend onderzoek (paragraaf 2.4).

${ }^{\mathrm{d}}$ Uitkomstmaat: $\mathrm{I}=$ effect op incidentie, $\mathrm{R}=$ effect op risicostatus, $\mathrm{K}=$ effect op klachten (paragraaf 2.4).

gegeneraliseerd kunnen worden, hoewel dergelijke effecten ook in een Nederlandse pilotstudie ( $\mathrm{n}=25$ ) gevonden zijn (Gelissen, persoonlijke communicatie). Momenteel loopt een gerandomiseerde effectstudie, waarvan de resultaten in 2008 worden verwacht.

Ontwikkelingsfase: I. Wetenschappelijke status: **.

- De cursus 'Lichte dagen, donkere dagen' (Can \& Voordouw, 2003) voor Turkse en Marokkaanse volwassenen is gebaseerd op de cursus 'In de put, uit de put'. Blijkens een pilotstudie bij 50 deelnemers was er een statistisch significante afname van depressiviteitsklachten (Can \& Voordouw, 2003).

Ontwikkelingsfase: G. Wetenschappelijke status: *.

- De internetcursus 'Kleur je leven' (Kramer \& Riper, 2005b) kent twee varianten: voor jongere en oudere volwassenen. Het is een zelfhulpcursus en gebaseerd op cognitief-gedragstherapeutische principes. Naar beide varianten loopt momenteel 
gerandomiseerd effectonderzoek. Er zijn nog geen resultaten beschikbaar voor de variant voor jongvolwassenen.

Ontwikkelingsfase: I. Wetenschappelijke status volwassenenversie: *.

\subsubsection{Gezondheidseffecten van preventie van depressie bij volwassenen}

Van de bovenbeschreven preventieve interventies voor volwassenen zijn er drie onderzocht in een gerandomiseerde studie: de groepscursus 'In de put, uit de put', de zelfhulpcursus 'In de put, uit de put', en de internetcursus 'Alles onder controle'. We bespreken deze studies om iets te kunnen zeggen over de behaalbare gezondheidswinst van de drie genoemde interventies.

\section{Groepscursus 'In de put, uit de put'}

De Nederlandse versie van de groepscursus 'In de put, uit de put' werd in een gerandomiseerd onderzoek geëvalueerd (Allart-van Dam, 2003). Deze onderzoekers hebben gekeken naar het effect van de interventie op de incidentie van depressie (tabel 3.6) en op depressiviteitsklachten (tabel 3.7).

Tabel 3.6: Effectiviteit van groepscursus 'In de put, uit de put' op de incidentie van depressie ${ }^{a}$.

\begin{tabular}{|c|c|c|c|c|}
\hline & & & $\begin{array}{l}\text { Interventiegroep } \\
\qquad(\mathrm{n}=45)\end{array}$ & $\begin{array}{c}\text { Controlegroep } \\
\qquad(\mathrm{n}=49)\end{array}$ \\
\hline Werd depressief & & & 17 & 10 \\
\hline Bleef depressievrij & & & 45 & 31 \\
\hline \multirow[t]{2}{*}{ Risico op de stoornis } & & & 0,27 & 0,25 \\
\hline & & $95 \% \mathrm{BI}$ & & \\
\hline Risicoverschil (RV) & $-0,03$ & $(-0,20 \sim 0,14)$ & & \\
\hline Relatief risico (RR) & 1,12 & $(0,40 \sim 1,09)$ & & \\
\hline NNT & nvt & & & \\
\hline
\end{tabular}

$\chi^{2}=0,06, \mathrm{p}=0,81$

a Allart-Van Dam (2003); voor een uitleg van deze tabel zie tekstblok 2.3.

Uit de bovenstaande tabel blijkt dat de interventie geen effect heeft op de incidentie van depressie. Onze berekening gaat uit van het 'intention-to-treat' principe, maar Allart-Van Dam (2003) komt tot dezelfde conclusie in haar proefschrift op basis van een 'completers-only' analyse. Echter, een recente meta-analyse van vier studies op dit terrein, inclusief de studie van Allart-van Dam, laat significante effecten zien op klachtenreductie, en bijna significante $(\mathrm{p}=0,07)$ effecten op de incidentie, die met gemiddeld $30 \%$ werd gereduceerd ten gevolge van de interventies (Cuijpers et al., aangeboden ter publicatie).

Dit type interventie kan echter wel op een effectieve manier bijdragen aan de reductie van het aantal depressiviteitsklachten. In de studie van Allart-Van Dam (2003, p. 50) 
werd namelijk ook bezien in hoeverre de interventie bijdraagt aan klachtenvermindering na een jaar (tabel 3.7).

Tabel 3.7: Effectiviteit van de groepscursus 'In de put, uit de put' op depressiviteitsklachten $\left(B D I^{a}\right)^{b}$.

\begin{tabular}{|c|c|c|c|c|}
\hline & & & $\begin{array}{l}\text { Interventiegroep } \\
\qquad(\mathrm{n}=62)\end{array}$ & $\begin{array}{l}\text { Controlegroep } \\
(n=41)\end{array}$ \\
\hline Pre: M (Sd) & & & $15,8(6,8)$ & $14,0(6,9)$ \\
\hline Post: M & & & 10,5 & 11,8 \\
\hline \multirow[t]{2}{*}{ Pre-post: d } & & & 0,78 & 0,32 \\
\hline & & $95 \% \mathrm{BI}$ & & \\
\hline$\Delta(\mathrm{d})$ & 0,46 & $(0,06 \sim 0,86)$ & & \\
\hline AUC & 0,63 & $(0,52 \sim 0,73)$ & & \\
\hline Risicoverschil (RV) & 0,26 & $(0,04 \sim 0,56)$ & & \\
\hline NNT & 3,9 & & & \\
\hline
\end{tabular}

a BDI= Beck's Depression Inventory (Beck et al., 1988).

b Allart-Van Dam, 2003; voor een uitleg van deze tabel zie tekstblok 2.3.

Het onderzoek laat een middelgroot effect zien op klachtenreductie. Bovendien werd in een meta-analyse van internationale gerandomiseerde studies naar de effecten van de cursus 'Omgaan met depressie' eveneens een middelgroot effect gevonden ten opzichte van controlegroepen (Cuijpers, 1998).

\section{Zelfhulpcursus met minimale begeleiding 'In de put, uit de put'}

In een gerandomiseerd effectonderzoek naar de cursus (Willemse et al., 2004) werden 915 mensen uit de doelgroep voor deelname werden benaderd. Daarvan namen er $216(23,6 \%)$ aan de interventie deel. Een jaar na aanvang van de interventie was de incidentie van depressie in de interventiegroep $12 \%$, tegen $18 \%$ in de controlegroep die gangbare huisartszorg ontving. Het risico op het ontstaan van depressie wordt onder invloed van de interventie dus teruggebracht tot $66 \%$ ten opzichte van het risico in de controlegroep $(\mathrm{p}=0,05)$. Daarnaast werd er een klein effect op depressiviteitsklachten gevonden. Uitgedrukt in de gestandaardiseerde effectgrootte $d$ is het effect van de interventie op depressiviteitsklachten gelijk aan 0,18 . In klinisch opzicht duidt dit op een klein, maar statistisch significant effect, $(p=0,03)$.

De interventie is bovendien kosteneffectief (Smit et al., 2006b): de combinatie van gangbare huisartsenzorg met een schriftelijke zelfhulpcursus heeft een kans van 70\% om kosteneffectiever te zijn dan alleen huisartsenzorg (tekstblok 3.1). Dit geldt in het zeer conservatieve scenario dat er geen bereidheid is om voor de verwachte gezondheidswinst (in de vorm van depressievrije levensjaren) extra te betalen. Anders gezegd, de kosten van de interventie worden gecompenseerd door vermeden uitgaven elders in de zorg, door verminderde productieverliezen, en door de geringere omvang van de kosten die voor rekening komen van de patiënt zelf. 
Tabel 3.8: Effectiviteit van zelfhulpcursus 'In de put, uit de put' op de incidentie van depressie ${ }^{a}$.

\begin{tabular}{|c|c|c|c|c|}
\hline & & & $\begin{array}{c}\text { Interventiegroep } \\
\quad(\mathrm{n}=107)\end{array}$ & $\begin{array}{c}\text { Controlegroep } \\
(n=109)\end{array}$ \\
\hline Werd depressief & & & 13 & 20 \\
\hline Bleef depressievrij & & & 94 & 89 \\
\hline \multirow[t]{2}{*}{ Risico op de stoornis } & & & 0,12 & 0,18 \\
\hline & & $95 \% \mathrm{BI}$ & & \\
\hline Risicoverschil (RV) & 0,06 & $(-0,02 \sim 0,14)$ & & \\
\hline Relatief risico (RR) & 0,66 & $(0,40 \sim 1,09)$ & & \\
\hline NNT & 16 & & & \\
\hline
\end{tabular}

Design-based test $\mathrm{p}=0,05$ (1-zijdig)

${ }^{a}$ Willemse et al., 2003; voor een uitleg van deze tabel zie tekstblok 2.3.

\section{Begeleide internetcursus 'Alles onder controle'}

Gerandomiseerd onderzoek (Van Straten et al., in voorbereiding) laat zien dat de interventie gunstige effecten heeft op depressiviteitsklachten, angstklachten, werkstress en burnout. Hier bespreken we alleen de effecten van de interventie op depressiviteitsklachten. De resultaten staan in tabel 3.9.

Tabel 3.9: Effectiviteit van de internetcursus 'Alles onder controle' op depressiviteitsklachten $\left(C E S-D^{a}\right)^{b}$.

\begin{tabular}{|c|c|c|c|c|}
\hline & & & $\begin{array}{l}\text { Interventiegroep } \\
\quad(n=107)\end{array}$ & $\begin{array}{c}\text { Controlegroep } \\
\qquad(\mathrm{n}=106)\end{array}$ \\
\hline Pre: M (Sd) & & & $29,9(9,1)$ & $29,9(9,2)$ \\
\hline Post: M & & & 20,6 & 26,1 \\
\hline \multirow[t]{2}{*}{ Pre-post: d } & & & 1,02 & 0,41 \\
\hline & & $95 \% \mathrm{BI}$ & & \\
\hline$\Delta(\mathrm{d})$ & 0,61 & $(0,34 \sim 0,88)$ & & \\
\hline AUC & 0,67 & $(0,59 \sim 0,73)$ & & \\
\hline RV & 0,33 & $(0,19 \sim 0,46)$ & & \\
\hline NNT & 3,0 & & & \\
\hline
\end{tabular}

a CES-D = Centre of Epidemiology Studies Depression scale (Radloff, 1977).

b Van Straten et al., in voorbereiding. Voor een uitleg van deze tabel zie tekstblok 2.3.

De data werden geanalyseerd in overeenstemming met het intention-to-treat principe. De controlegroep verbetert enigszins $(d=0,41)$, maar de experimentele groep verbetert meer $(\mathrm{d}=1,02)$. De meerwaarde van de experimentele conditie ten opzichte van de controleconditie is daarmee $1,02-0,41=0,61$ standaard eenheden. Dat is een middelgroot effect. De effectgrootte $d$ is door enige statistische onzekerheid omgeven $(\mathrm{BI}=0,34-0,88)$. De AUC geeft aan in hoeverre de interventie een grotere kans geeft op een goede uitkomst dan de controle conditie. Wanneer AUC groter is dan 0,50 is die kans in het voordeel van de interventie. Tabel 3.9 laat zien dat dit het geval is: AUC $=0,67$, en ook de ondergrens van AUC $(0,59)$ ligt boven de waarde van 0,50 . De 


\section{Tekstblok 3.1: Kosteneffectiviteitsanalyse zelfhulpcursus met minimale begeleiding 'In de put, uit de put'}

In het gerandomiseerd effectonderzoek naar de cursus (tabel 3.8) werden ook economische data verzameld waarmee een kosteneffectiviteitsanalyse (KEA) uitgevoerd kon worden (Smit et al., 2006b). In deze KEA werden drie soorten kosten meegenomen. Allereerst werden de directe medische kosten beschouwd: de kosten van de preventieve interventie, en de kosten die elders in de zorg werden gemaakt, bijvoorbeeld bij huisartsen en door geneesmiddelengebruik. Daarnaast werd gekeken naar de directe niet-medische kosten. Dat zijn kosten die voor rekening komen van patiënten in het kader van hun zorgconsumptie, zoals reiskosten, parkeergeld en de kosten van de tijd die patiënten kwijt zijn aan reizen, wachten en het ontvangen van hun behandeling. Ten slotte werd er ook gekeken naar de kosten die samenhangen met productieverliezen. Deze kunnen ontstaan door ziekteverzuim, maar ook wanneer mensen zich niet goed voelen, toch naar hun werk gaan, en vervolgens minder efficiënt werken. De kosten van productieverliezen werden berekend over betaalde, en ook over onbetaalde arbeid zoals in het eigen huishouden. De kosten werden uitgerekend in euro voor het peiljaar 2003, met als tijdshorizon één jaar. In bijlage 6 wordt in meer detail ingegaan op de berekening van economische effecten van preventie.

Wanneer alleen de kosten beschouwd worden en we laten de gezondheidseffecten van de interventie nog even buiten beschouwing, dan valt het volgende te rapporteren. De interventie kostte per ontvanger gemiddeld $€ 423$. Omdat de ontvangers van de interventie elders in de zorg minder kosten maakten, was iemand uit de interventiegroep slechts 60 euro per jaar duurder uit dan iemand die alleen gangbare zorg ontving. Die meerkosten zijn niet significant $(p=0,91)$, en Smit et al. concluderen daarom dat de interventie kostenneutraal is voor zo ver alleen naar de directe medische kosten wordt gekeken. Omdat ontvangers van de zelfhulp interventie minder gebruik maakten van de zorg, vermeed een ontvanger ook allerlei directe niet-medische kosten. Deze vermeden kosten bedroegen $€ 66$ per ontvanger per jaar $(p=0,45)$. Verder blijkt dat de ontvangers van de interventie productiever waren: zij verzuimden minder en waren tijdens hun werk efficiënter. Ten opzichte van de groep die alleen gangbare zorg ontving werden $€ 1.843$ minder verloren door productieverliezen $(p=0,26)$.

Beschouwen we alle kostenposten samen dan leverde de interventie per ontvanger per jaar een gemiddelde besparing op van $€ 1.890$. Rondom dit gemiddelde zit een aanzienlijke onzekerheidsmarge, en het kostenverschil is daarom statistisch niet significant $(p=0,28)$. We blijven daarom concluderen dat de interventie kostenneutraal is. Wel is er statistisch gezien een aanzienlijke kans dat de interventie kosteneffectiever is dan alleen gangbare zorg. Hier komen we zo op terug.

In een kosteneffectiviteitsanalyse worden in principe de kosten en de gezondheidseffecten gezamenlijk beschouwd. Het gaat dan om de meer/minder kosten van de interventie ten opzichte van de vergelijkingsgroep, per gewonnen depressievrij levensjaar. De zogenaamde 'incrementele kosteneffectiviteitsratio' (6.766 $-8.614)$ / $(88,1-81,7)$ laat zien dat de interventie 'dominant' is: voor elk gewonnen depressievrij levensjaar wordt ook nog eens gemiddeld 289 euro bespaard.

Rondom de gemiddelde besparing van 289 euro per gewonnen depressievrij levensjaar zit echter een onzekerheidsmarge. Daarom werd ten slotte berekend wat de kans is dat de interventie kosteneffectiever is dan gangbare zorg. Daarbij werd uitgegaan van een zeer conservatief scenario waarin de bereidheid om te betalen voor een gewonnen depressievrij levensjaar geheel ontbreekt. Zelfs in dit scenario blijkt de kans dat de interventie acceptabel is vanuit het oogpunt van kosteneffectiviteit $70 \%$ is.

Samenvattend concluderen Smit et al. (2006b) dat de zelfhulpinterventie met minimale begeleiding er niet alleen goed in slaagt om gezondheidswinst te genereren, maar dat gelijktijdig gemiddeld minder kosten worden gemaakt door de ontvangers van de interventie. Anders gezegd: waarschijnlijk verdient de interventie zich binnen één jaar terug. Wat er na dat jaar gebeurt in termen van gezondheidseffecten en kosten is overigens nog onbekend. 
NNT van 3,0 wijst op een grote efficiëntie van deze interventie wat betreft het reduceren van depressiviteitsklachten: slechts drie personen dienen de interventie te krijgen om bij één van hen de depressiviteitsklachten succesvol terug te dringen. De interventie had verder gunstige effecten op angst, maar in mindere mate op burnout.

\section{Te behalen gezondheidswinst op bevolkingsniveau}

Uit de studies die beschreven zijn bij de gezondheidseffecten kan geconcludeerd worden dat de zowel de groepscursus als de zelfhulpcursus 'In de put, uit de put' voor volwassenen effectief zijn in het verminderen van de incidentie. Beide zijn in een Nederlandse gerandomiseerde studie onderzocht. De internetcursus 'Alles onder controle' is effectief in het verminderen van depressiviteitsklachten, en is daarin met een NNT van drie ook efficiënt.

Het aantal volwassenen dat in een gegeven jaar voor het eerst in hun leven een depressieve stoornis ontwikkeld is 288.600 . We gaan verder uit van een bereik van $25 \%$ (realistisch) en 100\% (maximaal haalbaar) van de betreffende doelgroep. De resultaten zijn als volgt (zie ook tabel 3.14):

- Bij een bereik van 25\% van de doelgroep helpt de groepscursus 'In de put, uit de put' om bij 3.600 (maximaal 14.430) volwassenen tussen de 18 en 65 jaar een depressie te vermijden. In DALY's uitgedrukt gaat het om 830 (maximaal 3.300) DALY's die jaarlijks gewonnen (kunnen) worden.

- Voor de schriftelijke zelfhulpcursus 'In de put, uit de put' is het realistisch aantal te voorkomen gevallen van depressie 4.300 (maximaal 17.300), en de realistisch haalbare gezondheidswinst 1.000 (maximaal 4.000) DALY's per jaar.

- Brede implementatie van de begeleide internetcursus 'Alles onder controle' kan eveneens gezondheidswinst genereren. Omdat er geen effect op incidentie is onderzocht kunnen we niet kwantificeren hoeveel DALY's de interventie zou kunnen opleveren.

\subsection{Preventieve interventies voor depressie bij ouderen}

In deze paragraaf geven we een samenvatting van de in Nederland beschikbare preventieve interventies voor depressie bij ouderen. In paragraaf 3.5.1 komen de in Nederland beschikbare interventies aan bod. De interventies zijn ingedeeld in universele, selectieve en geïndiceerde preventie (zie paragraaf 2.3). Aan het eind van deze paragraaf staat een tabel met alle beschikbare interventies ter preventie van depressie bij ouderen (tabel 3.10). Paragraaf 3.5.2 beschrijft gezondheidseffecten van die interventies die in een gerandomiseerde studie geëvalueerd zijn, inclusief conclusies over de behaalbare gezondheidswinst. Voor een uitgebreide beschrijving van de in Nederland beschikbare interventies ter preventie van depressie bij ouderen verwijzen we naar bijlage 3. Voor een uitleg van de beoordeling op wetenschappelijke status en ontwikkelingsfase verwijzen we naar paragraaf 2.4 . 


\subsubsection{In Nederland beschikbare interventies ter preventie van depressie bij ouderen}

\section{Universele preventie}

Universele preventie van depressie bij ouderen heeft tot doel om ouderen vertrouwd te maken met het idee dat depressie niet iets is dat nu eenmaal hoort bij het ouder worden, dat depressie behandelbaar is, en vooral, dat zij zelf iets tegen depressie kunnen doen. Hiertoe zijn er enkele voorlichtingsactiviteiten beschikbaar in Nederland. Ook wordt universele preventie van depressie bij ouderen uitgevoerd onder het vaandel 'succesvol ouder worden', welke gericht is op versterking van competenties.

De volgende interventies voor preventie van depressie bij ouderen zijn in Nederland beschikbaar:

- De film 'De kunst van het ouder worden: stil staan en doorgaan bij ingrijpende gebeurtenissen' (Smits, 2003) wordt gebruikt in het kader van algemene voorlichtingsactiviteiten.

Ontwikkelingsfase: G. Wetenschappelijke status: *.

- Voor Turkse en Marokkaanse vrouwen zijn er informatieve huiskamerbijeenkomsten rond het thema 'Geestelijke gezondheid en ouder worden' (De Vries \& Smits, 2004).

Ontwikkelingsfase: G. Wetenschappelijke status: *.

- Voor mensen van 50 tot 70 jaar is er een cursus 'Op weg naar de gouden jaren' (Bode \& De Ridder, 2004). De effectiviteit wordt momenteel onderzocht in een gerandomiseerd onderzoek.

Ontwikkelingsfase: G. Wetenschappelijke status: *.

\section{Selectieve preventie}

- De groepscursus voor weduwen 'Verlies en dan verder' werd in quasi-experimenteel onderzoek geëvalueerd (Benthem et al., 1994; Van Lammeren \& Geelen, 1995). Ontwikkelingsfase: G. Wetenschappelijke status: ${ }^{* *}$.

- De cursus 'Preventie van depressie in verzorgingshuizen' (Van Mierlo et al., 2001) richt zich primair op het verzorgend personeel en via hen de bewoners van verzorgingshuizen, al bevat het ook componenten die rechtstreeks gericht zijn op de bewoners. Doel: deskundigheidsbevordering van verzorgend personeel gericht op vroegherkenning, verbeterde zorg en afname van depressiviteitsklachten. Quasiexperimenteel onderzoek (Cuijpers \& Van Lammeren, 2001) en een gerandomiseerd onderzoek (Eisses, 2005) lieten een afname van depressiviteitsklachten zien.

Ontwikkelingsfase: G. Wetenschappelijke status: **.

- Voor mensen met één of meer chronische ziekten is de cursus 'Leven met een chronische ziekte' beschikbaar (Cuijpers \& Van Osch, 2004; Voordouw et al., 2005). Deze interventie werd beschreven in paragraaf 3.4.1: Preventie van depressie bij volwassenen. De cursus wordt ook gegeven aan ouderen, omdat juist zij vaak één of meer chronische ziekten hebben.

Ontwikkelingsfase: G. Wetenschappelijke status: **. 
- Eveneens voor weduwen: ‘Bezoekdiensten van weduwen voor weduwen' (Schaper et al., 1997). Amerikaans onderzoek attendeert op de gunstige effecten ervan (Vachon et al., 1980) . Momenteel wordt Nederlands gerandomiseerd onderzoek uitgevoerd naar de kosteneffectiviteit van de interventie.

Ontwikkelingsfase: G. Wetenschappelijke status: **.

- Het project 'Activerend huisbezoek' (Linnemann et al., 2001) richt zich op ouderen (55+) die door opstapelende problemen (met gezondheid, verlies van dierbaren, kleiner wordend sociaal netwerk, problemen met financiën en huisvesting) het emotioneel niet goed redden.

Ontwikkelingsfase: G. Wetenschappelijke status: **.

\section{Geïndiceerde preventie}

- De groepscursus 'In de put, uit de put 55+' (Cuijpers, 2004b) wordt aangeboden aan 55-plussers met depressiviteitsklachten. Deze cursus is een variant op de groepscursus 'In de put, uit de put' voor volwassenen (zie paragraaf 3.4.1 en 3.4.2) en is gebaseerd op de sociale leertheorie over depressie en cognitieve gedragstherapie. De Nederlandse versie werd afgeleid van een cursus die door Lewinsohn (1984) in de Verenigde Staten werd ontwikkeld. In de cursus wordt aandacht besteed aan ontspanning, vermeerderen van het aantal plezierige activiteiten, constructief denken, verbeteren van sociale vaardigheden, en zorgdragen voor het behoud van behaalde effecten. Gerandomiseerd onderzoek toonde aan dat deze interventie effectief is in het reduceren van de risicostatus (Haringsma et al., 2005; zie paragraaf 3.5.2). Ontwikkelingsfase: G. Wetenschappelijke status: ${ }^{*}$.

- De schriftelijke zelfhulpversie van 'In de put, uit de put' (Willemse et al., 2004b) met minimale begeleiding is bedoeld voor volwassen huisartspatiënten met een subklinisch beeld van depressie, waaronder ook ouderen. Deze interventie is beschreven in paragraaf 3.4.1: Preventie van depressie bij volwassenen.

Ontwikkelingsfase: I. Wetenschappelijke status: ${ }^{* *}$.

- De groepscursus 'Het verhaal van je leven' (de nieuwe titel wordt 'De verhalen die we leven’; Bohlmeijer, 2006) is gericht op mensen vanaf 55 jaar met als doel het versterken van het gevoel van eigenwaarde en zingeving, en vermindering van depressiviteitsklachten. In het buitenland zijn tal van studies uitgevoerd naar de effecten van soortgelijke interventies - de zogenaamde 'life-review' - op depressiviteitsklachten. Bohlmeijer et al. (2003a) evalueerden in een meta-analyse de effectiviteit van life-review op depressiviteitsklachten, maar we houden een slag om de arm wat betreft de Nederlandse interventie.

Ontwikkelingsfase: I. Wetenschappelijke status: ${ }^{*}$.

- De internetcursus ‘Kleur je leven’ (Riper \& Kramer, 2004) is een zelfhulpcursus gebaseerd op cognitief-gedragstherapeutische principes. Deelnemers gaan geheel zelfstandig met deze cursus aan de slag. De cursus bevat cognitief gedragstherapeutische elementen waarvan de werking bij depressie is aangetoond. Er is een versie voor volwassenen en voor mensen ouder dan 50 jaar. Beide cursussen bestaan uit acht lessen en een opfrisles na 12 weken. Naar beide varianten loopt momenteel gerandomiseerd effectonderzoek (Spek et al., in voorbereiding). Er zijn recentelijk gegevens beschikbaar gekomen over het effect van deze interventie bij ouderen (paragraaf 3.5.2).

Ontwikkelingsfase: I. Wetenschappelijke status: ${ }^{* *}$. 
- De cursus ‘Op zoek naar zin’ (Franssen \& Bohlmeijer, 2003) is een groepscursus voor mensen vanaf 55 jaar met depressiviteitsklachten die bovendien bezig zijn met vragen over zingeving. Een niet-gerandomiseerde studie (Bohlmeijer et al., 2003b; Franssen \& Bohlmeijer, 2003) liet zien dat deelnemers meer greep hebben op hun leven, minder depressiviteitsklachten hebben en meer tevreden zijn met hun leven. Momenteel wordt een gerandomiseerd effectonderzoek in Nederland uitgevoerd, waarvan de resultaten in 2007 worden verwacht.

Ontwikkelingsfase: I. Wetenschappelijke status: *

Tabel 3.10: Overzicht van in Nederland beschikbare interventies ter preventie van depressie bij ouderen.

\begin{tabular}{|c|c|c|c|c|c|}
\hline & $\begin{array}{l}\text { Soort } \\
\text { interventie }^{\text {a }}\end{array}$ & $\begin{array}{l}\text { Ontwikke- } \\
\text { lingsfase }\end{array}$ & $\begin{array}{l}\text { Weten. } \\
\text { status c }\end{array}$ & $\begin{array}{l}\text { Uitkomst- } \\
\text { maat }^{d}\end{array}$ & Doelgroep \\
\hline \multicolumn{6}{|l|}{ Universeel } \\
\hline $\begin{array}{l}\text { Kunst van ouder } \\
\text { worden }\end{array}$ & Film & G & * & - & Ouderen \\
\hline $\begin{array}{l}\text { Huiskamerbijeen- } \\
\text { komsten }\end{array}$ & Groep & G & $*$ & - & $\begin{array}{l}\text { Turkse en Marok- } \\
\text { kaanse vrouwen }\end{array}$ \\
\hline $\begin{array}{l}\text { Op weg naar gouden } \\
\text { jaren }\end{array}$ & $\begin{array}{l}\text { Groep en } \\
\text { individueel }\end{array}$ & G & * & onbekend $^{\mathrm{e}}$ & Ouderen (50-70 jaar) \\
\hline \multicolumn{6}{|l|}{ Selectief } \\
\hline Verlies en dan verder & Groep & G & ** & $\mathrm{K}$ & Weduwen (60+) \\
\hline $\begin{array}{l}\text { Preventie van } \\
\text { depressie }\end{array}$ & Groep & G & ** & K & $\begin{array}{l}\text { Bewoners van } \\
\text { verzorgingshuizen }\end{array}$ \\
\hline $\begin{array}{l}\text { Leven met een } \\
\text { chronische ziekte }\end{array}$ & Groep & G & $* *$ & $\mathrm{~K}$ & $\begin{array}{l}\text { Volwassenen en } \\
\text { ouderen met } \\
\text { chronische ziekte }\end{array}$ \\
\hline Bezoekdiensten & Individueel & G & $* *$ & $\mathrm{~K}$ & Weduwen \\
\hline $\begin{array}{l}\text { Activerend } \\
\text { huisbezoek }\end{array}$ & Individueel & G & $*$ & K & Eenzame ouderen \\
\hline \multicolumn{6}{|l|}{ Geïndiceerd } \\
\hline In/uit de put 55+ & Groep & G & $* *$ & $\mathrm{~K}$ & $\begin{array}{l}\text { Ouderen met } \\
\text { depress. klachten }\end{array}$ \\
\hline In/uit de put & Zelfhulp & G & $* *$ & I & $\begin{array}{l}\text { Ouderen met } \\
\text { depress. klachten }\end{array}$ \\
\hline Verhaal van je leven & Groep & I & ** & $\mathrm{K}$ & $\begin{array}{l}\text { Ouderen met } \\
\text { depress. klachten }\end{array}$ \\
\hline Kleur je leven & Internet & I & ** & $\mathrm{R}$ & $\begin{array}{l}\text { Ouderen met } \\
\text { depress. klachten }\end{array}$ \\
\hline Op zoek naar zin & Groep & I & * & $\mathrm{K}$ & $\begin{array}{l}\text { Ouderen met } \\
\text { depress. klachten }\end{array}$ \\
\hline \multicolumn{6}{|c|}{$\begin{array}{l}\text { a Soort interventie: Les: lesprogramma op scholen, Groep=groepscursus, Internet=internet-groepscursus } \\
\text { (paragraaf 2.3). } \\
\text { b Ontwikkelingsfase: I = innovatief, G = gestandaardiseerd (paragraaf 2.4). } \\
\text { c Wetenschappelijke status: * = gepubliceerde mening van deskundigen, of mening van werkgroepleden, } \\
\text { ** = gebaseerd op één gerandomiseerde trial of meerdere onderzoeken zonder controlegroep (paragraaf } \\
\text { 2.4). } \\
\text { d Uitkomstmaat in onderzoek: ; I = effect op incidentie, } \mathrm{R}=\text { effect op risicostatus, } \mathrm{K}=\text { effect op klachten, } \\
\text { effecten op tussengelegen doelen, bijvoorbeeld sociale competentie i.p.v. depressie (paragraaf 2.4). } \\
\text { e Lopend effectonderzoek. }\end{array}$} \\
\hline
\end{tabular}




\subsubsection{Gezondheidseffecten van preventie van depressie bij ouderen}

Tot dusver zijn vier interventies voor depressiepreventie bij ouderen die in Nederland worden aangeboden in gerandomiseerde trials onderzocht: de groepscursus 'In de put, uit de put 55+', de zelfhulpcursus 'In de put, uit de put', de groepscursus 'Het verhaal van je leven' en de internetcursus ‘Kleur je leven'. We bespreken deze studies om iets te kunnen zeggen over de behaalbare gezondheidswinst van de vier genoemde interventies.

\section{Groepscursus 'In de put, uit de put 55+'}

Blijkens buitenlands onderzoek is deze cursus effectief (Kühner, 2003). Ook volgens Nederlands gerandomiseerd onderzoek (Haringsma et al., 2005) is de interventie effectief. Haringsma et al. onderzochten in hoeverre mensen met een verhoogde risicostatus voor depressie (een score van $>16$ op de CES-D) onder invloed van de interventie die ongunstige risicostatus verloren in vergelijking tot een wachtlijstcontrole groep. Na veertien maanden werd de balans opgemaakt. De resultaten staan in tabel 3.11.

Tabel 3.11: Effectiviteit van 'In de put, uit de put 55+' op risicostatus voor depressie bij ouderen (CES$\left.D^{a}\right)^{b}$.

\begin{tabular}{lccc}
\hline & & $\begin{array}{c}\text { Interventiegroep } \\
(\mathrm{n}=52)\end{array}$ & $\begin{array}{c}\text { Controlegroep } \\
(\mathrm{n}=45)\end{array}$ \\
\hline Bleef risico houden & & 40 & 45 \\
Verloor risicostatus & & 12 & 0 \\
Risico op de stoornis & & 0,77 & 1,00 \\
& & & \\
Risicoverschil (RV) & 0,23 & $(0,12 \sim 0,35)$ & \\
Relatief risico (RR) & 0,77 & $(0,66 \sim 0,89)$ & \\
NNT & 4,3 & & \\
\hline
\end{tabular}

$\chi^{2}=11,85, p=0,00$

${ }^{a}$ CES-D=Centre of Epidemiology Studies Depression scale (Radloff, 1977).

b Haringsma et al., 2005, voor een uitleg van deze tabel zie tekstblok 2.3.

De tabel laat statistisch significante effecten zien, waarbij de NNT aantoont dat 4 tot 5 personen de interventie moeten ontvangen om bij één van hen de risicostatus tot een aanvaardbaar niveau te doen dalen. Dit kan gezien worden als efficiënt. De effecten van de interventie op bevolkingsniveau laten zich bij benadering kwantificeren. In de groep van minimaal 700 ouderen die de cursus per jaar volgden verloren 161 personen dankzij de interventie hun risicostatus.

\section{Zelfhulpcursus 'In de put, uit de put'}

De zelfhulpcursus 'In de put, uit de put' werd al bij de doelgroep volwassenen (huisartspatiënten) beschreven (paragraaf 3.4.2), maar staat ook open voor huisartspatiënten van 65 jaar en ouder. Daar merkten wij op dat het risicoverschil op het ontstaan 
van een depressie tussen de experimentele en de controle groep 6\% is, en het risico op een depressie $66 \%$ is ten opzichte van het risico in de controlegroep.

\section{Groepscursus 'Het verhaal van je leven'}

Bohlmeijer et al (2003a) voerden een meta-analyse uit naar de effectiviteit van groepscursussen die vergelijkbaar zijn met 'Het verhaal van je leven': de zogenaamde lifereviews. De meta-analyse onderzocht het effect van life-review op depressiviteitsklachten. Bohlmeijer et al vonden vijf gerandomiseerde buitenlandse studies met in totaal 512 participanten. De resultaten van deze meta-analyse staan in tabel 3.12.

Tabel 3.12: Effect van 'Het verhaal van je leven' op depressiviteitsklachten (meta-analyse) ${ }^{a}$.

\begin{tabular}{lcc}
\hline & Schatting & $95 \%$ BI \\
\hline d & 0,92 & $(0,49 \sim 1,35)$ \\
AUC & 0,74 & $(0,64 \sim 0,83)$ \\
RV & 0,48 & $(0,27 \sim 0,66)$ \\
NNT & 2,1 & \\
\hline
\end{tabular}

${ }^{\text {a }}$ Bohlmeijer et al. (2003a). Voor een uitleg van deze tabel zie tekstblok 2.3.

De gevonden effecten zijn statistisch significant en in klinisch opzicht groot te noemen. Blijkens de lage NNT ontstaat dit effect bovendien op een efficiënte manier. In Nederland wordt deze interventie momenteel op kleine schaal getest: vijf GGZ-preventieafdelingen bieden verschillende varianten van de cursus aan in het kader van een pilot-onderzoek. Het is daarom te vroeg om te zeggen wat de gezondheidswinst is die met deze interventie wordt behaald, maar de vooruitzichten zijn veelbelovend.

\section{Zelhulpcursus via het internet 'Kleur je leven'}

De cursusvariant voor ouderen wordt momenteel in een gerandomiseerd effectonderzoek geëvalueerd (Spek et al., in voorbereiding). De eerste gegevens, gemeten direct na het beëindigen van de interventie, zijn inmiddels bekend (Spek, pers. com.). Bezien werd of de deelnemers die de interventie ontvingen hun risicostatus op depressie blijkens verhoogde scores op de Edinburgh Depression Scale (EDS $>12$ ) in grotere getalen kwijtraakten dan mensen die alleen gangbare zorg ontvingen. De trialdata laten inderdaad zien dat minder deelnemers in experimentele groep hun ongunstige risicostatus behielden (45\%) ten opzichte van de controlegroep (57\%; tabel 3.13). In een 1-zijdige toets horend bij de hypothese dat de interventie een meerwaarde moet opleveren, is dit verschil ook statistisch significant $(p=0,045)$.

\section{Te behalen gezondheidswinst op bevolkingsniveau}

In de paragraaf over depressiepreventie bij volwassenen is geconcludeerd dat de zelfhulpcursus 'In de put, uit de put' effectief is in het verminderen van de incidentie. Dit geldt zowel voor ouderen als voor volwassenen. Uit de voorgaande gegevens over depressiepreventie bij ouderen kunnen we constateren dat de groepscursus 'In de put, uit de put 55+' voor ouderen bewezen effectief is in het verminderen van de risicostatus voor depressie. Dit is onderzocht in Nederlands gerandomiseerd onderzoek. 
Tabel 3.13: Effectiviteit van de online zelfhulpcursus 'Kleur je leven' op risicostatus (EDS $\left.{ }^{a}\right)^{b}$.

\begin{tabular}{|c|c|c|c|c|}
\hline & & & $\begin{array}{l}\text { Interventiegroep } \\
\qquad(\mathrm{n}=102)\end{array}$ & $\begin{array}{c}\text { Controlegroep } \\
(n=100)\end{array}$ \\
\hline Met risico (EDS>12) & & & 46 & 57 \\
\hline Zonder risico & & & 56 & 43 \\
\hline \multirow[t]{2}{*}{ Risico op EDS>12 } & & & 0,45 & 0,57 \\
\hline & & $95 \% \mathrm{BI}$ & & \\
\hline Risicoverschil (RV) & 0,12 & $-0,26 \sim 0,02$ & & \\
\hline Relatief risico (RR) & 0,79 & $0,60 \sim 1,04$ & & \\
\hline NNT & 8,4 & & & \\
\hline
\end{tabular}

${ }^{2}=2,86 ; \mathrm{df}=1 ; \mathrm{p}=0,045$ (1-zijdig)

${ }^{\text {a }}$ EDS= Edinbrugh Depression Scale (Cox et al., 1987).

b Spek et al., in voorbereiding; voor een uitleg van deze tabel zie tekstblok 2.3 .

Het aantal ouderen (65+) dat voor het eerst in hun leven een depressie krijgt wordt geschat op 19.000 personen. Bij een bereik van de interventies van 25\% (realistisch) en 100\% (maximaal behaalbaar) van die doelgroep, genereren de betreffende interventies de volgende gezondheidswinst (tabel 3.14):

- Met de zelfhulpcursus 'In de put, uit de put' worden bij 290 (maximaal 1.100) ouderen van $65+$ het ontstaan van een depressie vermeden. Daarmee worden per jaar 70 (maximaal 260) DALY's gewonnen.

\subsection{Samenvatting en conclusies preventie van depressie}

De omvang van depressie is aanzienlijk: per jaar lijden naar schatting 737 duizend mensen in Nederland eraan. De gevolgen van depressie zijn groot: de ziektelast bedraagt minimaal 158 duizend DALY's en de zorgkosten lopen op tot in totaal zo'n 660 miljoen euro. Daarnaast kost het ziekteverzuim als gevolg van depressie 953 miljoen per jaar. Bovendien waren in 2002 ruim 53 duizend mensen als gevolg van depressie arbeidsongeschikt. Het aantal nieuwe gevallen van depressie bedraagt jaarlijks naar schatting bijna 359 duizend mensen; zij vertegenwoordigen ongeveer 66 duizend DALY's. De zorgkosten voor nieuwe gevallen van depressie bij volwassenen bedragen jaarlijks zo'n 124 miljoen euro; daarnaast genereren deze volwassenen ruim 467 miljoen euro aan productieverliezen door ziekteverzuim. Gezien de grote omvang van depressie, de hoge jaarlijkse instroom van nieuwe gevallen, en de forse ziektelast waarmee deze stoornis gepaard gaat is een ruim en gevarieerd preventief interventieaanbod van belang.

Er worden aanzienlijke inspanningen geleverd op het gebied van universele, selectieve en geïndiceerde preventie voor depressie. Bij depressiepreventie ligt de focus vooral op geïndiceerde preventie. Dit is een voor de hand liggende insteek: het gaat immers om mensen met klachten die kunnen wijzen op een beginnende depressie. Het gaat bovendien om mensen bij wie al enige lijdensdruk aanwezig is, waardoor ze eerder geneigd zijn om deel te nemen aan een interventie. De aangeboden interventies werden 
afgeleid van therapievormen die in de curatieve GGZ hun waarde bewezen hebben, zoals cognitieve gedragstherapie en interpersoonlijke therapie. Veel van de preventieve interventies zijn bovendien in effectstudies geëvalueerd. Tabel 3.14 geeft een overzicht van die interventies en vat samen wat per interventie de haalbare gezondheidswinst is op bevolkingsniveau. Daarbij zijn we uitgegaan van een realistisch te behalen bereik van $25 \%$. Deze realistisch behaalbare gezondheidswinst kan in de tabel vergeleken worden met een theoretisch maximum in het hypothetisch scenario van een bereik van $100 \%$.

De tabel laat zien dat het in principe makkelijker is om klachten te reduceren dan om de risicostatus of de kans op het ontwikkelen van een stoornis te beïnvloeden: de effecten (risicoverschil) zijn het grootst bij reductie van klachten en het kleinst bij een reductie in incidentie. Een ander aspect dat opvalt, is dat zelfhulpversies het niet slechter doen dan groepscursussen onder professionele begeleiding. Vanuit het oogpunt van kosteneffectiviteit kan dit interessant zijn. Hierbij dient bedacht te worden dat voor groepen met ernstiger problematiek of met een grotere kwetsbaarheid zelfhulpcursussen misschien niet geschikt zijn en dat zulke groepen aangewezen blijven op groepscursussen met professionele begeleiding.

\section{Aanbevelingen voor depressiepreventie bij jongeren}

Voor de geïndiceerde preventie van depressie bij jongeren zijn er vermoedelijk effectieve groepsinterventies beschikbaar zoals 'Stemmingmakerij', 'Een stap op weg' en 'Grip op je dip’, waarbij we ook de internetversie van ‘Grip op je dip’ willen noemen. Deze interventies komen in aanmerking voor implementatieonderzoek, waarbij tegelijkertijd ook onderzoek naar de effectiviteit ervan op zijn plaats is.

De selectieve interventies 'KOPP’ en 'Psycho-educatieve gezinsinterventie’ hebben prioriteit voor effectonderzoek: beide worden al op grotere schaal toegepast maar het bewijs voor de wetenschappelijke effectiviteit ervan is nog onvoldoende.

Hetzelfde geldt voor de universele interventies 'Levensvaardigheden' en 'Leefstijl', al kan het naar de aard van deze interventies nog moeilijk worden om ze goed te onderzoeken. Al met al verdient depressiepreventie bij jongeren nadere investering, zowel in de vorm van nader effectonderzoek, als in de vorm van implementatiestudies: het aantal aantrekkelijke, goed toegankelijke en bewezen effectieve interventies is nog klein.

\section{Aanbevelingen voor depressiepreventie bij volwassenen}

Het aanbod van depressiepreventie voor volwassenen staat redelijk goed op de rails: er is een rijk en gevarieerd aanbod voor diverse groepen en de interventies zijn van redelijke kwaliteit. Voor geïndiceerde preventie van depressie zijn de groepscursus en de zelfhulpcursus 'In de put, uit de put' effectief in het verminderen van de incidentie. De zelfhulpvariant ervan voor huisartspatiënten is bovendien kosteneffectief. De internetcursus 'Alles onder controle' is effectief in het verminderen van depressiviteitsklachten. Deze drie cursussen zijn gezien hun wetenschappelijke status (twee sterren) geschikt voor implementatiestudies. 
Tabel 3.14: Gezondheidswinst van interventies ter preventie van depressie, uitegedrukt in te voorkomen nieuwe gevallen van depressie en te voorkomen DALY's.

\begin{tabular}{|c|c|c|c|c|c|c|c|}
\hline & \multicolumn{2}{|c|}{$\begin{array}{l}\text { Uitkomst maat }+ \\
\text { bewijskracht }^{\mathrm{a}}\end{array}$} & \multirow[t]{3}{*}{$\begin{array}{c}\text { Risico- } \\
\text { verschil }^{b}\end{array}$} & \multicolumn{4}{|c|}{$\begin{array}{l}\text { Te behalen gezondheidswinst bij } 25 \% \\
\text { bereik en } 100 \% \text { bereik }\end{array}$} \\
\hline & & & & \multicolumn{2}{|c|}{$\begin{array}{c}\text { Te voorkomen } \\
\text { nieuwe gevallen }\end{array}$} & \multicolumn{2}{|c|}{$\begin{array}{l}\text { Te voorkomen } \\
\text { DALY's c g }\end{array}$} \\
\hline & & & & $25 \%$ & $100 \%$ & $25 \%$ & $100 \%$ \\
\hline \multicolumn{8}{|l|}{ Jongeren } \\
\hline $\begin{array}{l}\text { Een stap op weg / } \\
\text { Grip op je dip (GC) }\end{array}$ & I & ** & $0,15^{d}$ & 1.900 & 7.600 & 440 & 1.800 \\
\hline \multicolumn{8}{|l|}{ Volwassenen } \\
\hline $\begin{array}{l}\text { In de put, uit de } \\
\text { put (GC) }\end{array}$ & I & $* * *$ & 0,05 & 3.600 & 14.400 & 830 & 3.300 \\
\hline $\begin{array}{l}\text { In de put, uit de } \\
\text { put }(\mathrm{ZH})\end{array}$ & I & ** & 0,06 & 4.300 & 17.300 & 1.000 & 4.000 \\
\hline $\begin{array}{l}\text { Alles onder } \\
\text { controle (IC) }\end{array}$ & $\mathrm{K}$ & ** & 0,33 & - & - & - & - \\
\hline \multicolumn{8}{|l|}{ Ouderen } \\
\hline $\begin{array}{l}\text { In de put, uit de } \\
\text { put }(\mathrm{ZH})\end{array}$ & I & ** & 0,06 & 290 & 1.100 & 70 & 260 \\
\hline $\begin{array}{l}\text { In de put, uit de } \\
\text { put } 55+(G C)\end{array}$ & $\mathrm{R}$ & ** & 0,23 & - & - & - & - \\
\hline $\begin{array}{l}\text { Verhaal van je } \\
\text { leven }(G C)\end{array}$ & $\mathrm{K}$ & ** & 0,48 & - & - & - & - \\
\hline Kleur je leven (IC) & $\mathrm{R}$ & ** & 0,12 & - & - & - & - \\
\hline $\begin{array}{l}\text { a Uitkomstmaat: I = inc } \\
\text { b Risicoverschil: het veI } \\
\text { (hoofdstuk 2). } \\
\text { c Wegingsfactor = 0,46 } \\
\text { d Gemiddelde van beid } \\
\text { f Berekening: incidenti } \\
\text { g Berekening: incidenti } \\
\text { 1.1). }\end{array}$ & $\begin{array}{l}\text { dentie } \\
\text { chil in } \\
\text { studie } \\
\text { * bere } \\
\text { * bere }\end{array}$ & $\begin{array}{l}\text { phtenr } \\
\text { p depre } \\
\text { larke et } \\
\text { coversc } \\
\text { coversc }\end{array}$ & $\begin{array}{l}\text { ductie, } R=\text { ve } \\
\text { sie tussen de } \\
\text { l. (1995, } 200 \\
\text { il (paragraaf } \\
\text { il ziekteduu }\end{array}$ & $\begin{array}{l}\text { rdwijnen r } \\
\text { interventie }\end{array}$ & $\begin{array}{l}\text { ostatus (h } \\
\text { ep en de }\end{array}$ & $\begin{array}{l}\text { stuk 2). } \\
\text { trolegrc } \\
\text { f } 2.5 \text { en }\end{array}$ & blok \\
\hline
\end{tabular}

De selectieve groepscursusen 'Leven met een chronische ziekte', 'KOPP 16+' en 'Verlies en dan verder' zijn kansrijk, maar de effecten dienen bijvoorkeur eerst in een gerandomiseerde studie te worden aangetoond. Bij het aanbod voor volwassenen dient onderzoek en ontwikkeling van interventies voor sociaal-economische achterstandsgroepen en allochtonen voortgezet te worden. Zo is de groepscursus 'Lichte dagen, donkere dagen' voor allochtonen nog nooit in een gerandomiseerd onderzoek geëvalueerd terwijl dit een groeiende doelgroep is.

Bewegingsgerichte interventies zoals 'Liever bewegen dan moe' en 'Bewegen zonder zorgen' die zich richten op achterstandgroepen zijn erg interessant. Deze interventievorm met lichamelijke fitheid als insteek is wellicht een goede manier om deze groepen te bereiken; bovendien is de internationale literatuur duidelijk over de kleine maar gunstige effecten ervan. We zouden daarom vooral via implementatiestudies willen weten of de betreffende doelgroep bereikt wordt en in hoeverre zij baat heeft bij deze interventies. 
Er is geen coherent landelijk aanbod van universele preventie van depressie voor volwassenen. Dit zou een belangrijke aanvulling zijn op het bestaande preventieaanbod, omdat het de drempel naar geïndiceerde preventie verlaagt.

\section{Aanbevelingen voor depressiepreventie bij ouderen}

Depressiepreventie bij ouderen is een gebied dat ruimschoots in beweging is. Met name voor deze leeftijdsgroep is een gevarieerd aanbod nodig, want met de hogere leeftijd komt ook de blootstelling aan allerlei risicofactoren die de kans op depressie aanzienlijk vergroten, zoals verlies van de levenspartner, vereenzaming, lichamelijke ziekten, opname in een verzorgings- of verpleeghuis. Verder wordt deze bevolkingsgroep door de vergrijzing steeds groter. Voor deze leeftijdsgroep lijkt er in Nederland een gevarieerd aanbod te ontstaan. Er zijn momenteel verscheidene interventies beschikbaar. Internationaal gezien is Nederland zelfs koploper op het gebied van depressiepreventie voor ouderen.

Voor geïndiceerde preventie van depressie bij ouderen is - evenals bij volwassenen de zelfhulpcursus 'In de put, uit de put' effectief in het verminderen van de incidentie. De groepscursus 'In de put, uit de put 55+' voor ouderen is effectief in het verminderen van de risicostatus voor depressie. Beide interventies zijn geschikt voor brede implementatie. Een kansrijke geïndiceerde interventie is ‘Op zoek naar zin’. Naar deze interventie loopt momenteel gerandomiseerd effectonderzoek. Ook de internetinterventie 'Kleur je leven' voor ouderen wordt momenteel op effectiviteit onderzocht. Beide interventies komen na gebleken effectiviteit in aanmerking voor bredere implementatie.

Voor selectieve preventie van depressie bij ouderen zijn er eveneens kansrijke interventies die in aanmerking lijken te komen voor implementatieonderzoek, zoals 'Verlies en dan verder', 'Activerend huisbezoek' en 'Bezoekdiensten voor weduwen'. De laatste interventie wordt momenteel op kosteneffectiviteit onderzocht.

Universele preventie van depressie bij ouderen kent nog geen coherent landelijk aanbod. Er bestaat de film 'De kunst van het ouder worden', en er is de interventie 'Op weg naar gouden jaren', bedoeld voor mensen die zich willen voorbereiden op het ouder worden. Voor Turken en Marokkaanse vrouwen zijn er de zogenaamde 'Huiskamerbijeenkomsten'. Over de effectiviteit van deze interventies zou men meer willen weten, maar alleen naar ‘Op weg naar gouden jaren’ loop een gerandomiseerd effectonderzoek.

\section{Algemene aanbevelingen bij depressiepreventie}

Al met al zijn er drie groepen waar het geïndiceerde aanbod extra aandacht behoeft: scholieren die wellicht meer openstaan voor internetinterventies, allochtonen voor wie nog geen bewezen effectieve interventies beschikbaar zijn, en ouderen omdat zij een groeiende bevolkingslaag zijn waarin vele risicofactoren voor depressie samenkomen. Voor wat betreft wetenschappelijke onderbouwing verdienen selectieve interventies meer aandacht. Tot nu toe heeft effectonderzoek naar selectieve preventieve interventies zich voornamelijk gericht op intermediaire uitkomstmaten, zoals een beter 
probleemoplossend vermogen of verbeterde sociale competenties, maar minder op gezondheidsmaten zoals reductie van depressiviteitsklachten en het voorkomen van het ontstaan een depressie. Zulke studies zouden bijvoorkeur als een gerandomiseerde effectstudie uitgevoerd moeten worden.

Voor de interventies waarvan de effectiviteit voldoende is bewezen geldt dat hun bereik aanzienlijk groter zou moeten worden. Door het geringe bereik blijft de werkelijk behaalde gezondheidswinst ver achter bij de theoretisch te behalen gezondheidswinst. Het bereik kan vergroot worden door deze interventies op grotere schaal aan te bieden. En door ze aan te bieden in de vorm van zelfhulpcursussen via het internet. Het vergroten van het bereik vraagt eigenlijk om een landelijk implementatieplan, en niet om ad hoc oplossingen op regionaal niveau (zie hoofdstuk 7). Het zou in navolging van het 'Partnership Vroegsignalering Alcohol' (zie hoofdstuk 4) wellicht goed zijn ook een 'Partnership Vroegsignalering Depressie' te organiseren met VWS en samenwerkende partijen om zo'n nationaal actieplan uit te werken en om in regionale proeftuinen ervaring op te doen. ZonMw zou een belangrijke rol kunnen vervullen door implementatiestudies te stimuleren van gestandaardiseerde interventies (ontwikkelingsfase G) waarbij al enige evidentie is over hun werkzaamheid (met een wetenschappelijke status van twee of drie sterren). Daarnaast blijft onderzoek naar de effectiviteit van preventieve interventies van cruciaal belang. Een kwaliteitsgarantie voor effectiviteit is nodig voor zowel toekomstige gebruikers van de interventies als voor verwijzers, en kan het gebruik en de acceptatie van dit soort interventies in gunstige zin helpen beïnvloeden.

Voor onderzoeksaanbevelingen over omvang, ernst en gevolgen van depressie verwijzen we naar hoofdstuk 6. 



\section{PREVENTIE VAN ANGSTSTOORNISSEN}

Dit hoofdstuk begint met een korte beschrijving van de kenmerken van angststoornissen: definitie, beloop en doelgroepen voor preventie van angststoornissen (paragraaf 4.1). Daarna geven we een overzicht van de epidemiologische kenmerken van angststoornissen: omvang, ernst en gevolgen (4.2). In de daarop volgende paragrafen bespreken we preventieve interventies bij jongeren (4.3), en bij volwassenen en ouderen (4.4). Omdat slechts enkele interventies zich specifiek richten op ouderen, hebben we in dit hoofdstuk geen aparte paragraaf over ouderen opgenomen. In de paragrafen 4.3 en 4.4 komen achtereenvolgens aan bod: de in Nederland beschikbare interventies, de gezondheidseffecten van effectieve interventies en conclusies over de haalbare gezondheidswinst van preventieve interventies. Het hoofdstuk eindigt met een samenvatting en conclusies (4.5). Alle in dit hoofdstuk genoemde interventies staan ook uitgebreid beschreven in bijlage 4.

\subsection{Definitie, beloop en doelgroepen voor preventie}

De hieronder volgende informatie is grotendeels gebaseerd op bestaande overzichtsliteratuur voor kenmerken van angststoornissen. Voor een uitgebreide beschrijving van kenmerken, duur en beloop van angststoornissen verwijzen we naar deze overzichtsliteratuur. Het betreft de volgende bronnen: APA (2001), Van Balkom et al. (2005a; 2005b), Emmelkamp et al. (2000), De Haan en de Wit (2000), Schoemaker et al. (2002), Schoemaker \& De Ruiter (2003) en Sytema et al. (1999).

\section{Definitie van angststoornissen}

Een angststoornis kan volgens de DSM IV (APA, 2001) verschillende vormen aannemen. In dit hoofdstuk gaan we bij de preventieve interventies in op de volgende angststoornissen:

- gegeneraliseerde angststoornis;

- paniekstoornis (met en zonder agorafobie);

- sociale fobie.

De andere angststoornissen (agorafobie zonder paniek, obsessief-compulsieve stoornis, specifieke fobie, posttraumatische stressstoornis en acute stressstoornis) worden niet afzonderlijk besproken. Redenen hiervoor zijn een lage prevalentie (obsessief-compulsieve stoornis) of onvoldoende wetenschappelijke kennis over preventie (specifieke fobie, agorafobie zonder paniekstoornis, posttraumatische stressstoornis, acute stressstoornis).

\section{Gegeneraliseerde angststoornis}

Mensen met een gegeneraliseerde angststoornis zijn voortdurend angstig en bezorgd over alledaagse dingen, en hebben moeite om deze zorgen en angsten onder controle te houden. Daarnaast zijn er bij volwassenen ten minste drie en bij kinderen één van 
de volgende symptomen voortdurend aanwezig gedurende een periode van minstens zes maanden: een constant gevoel van onrust en spanning, snel vermoeid, moeite met concentreren, geïrriteerdheid, spierspanning en/of verstoorde slaap.

\section{Paniekstoornis}

Iemand met een paniekstoornis krijgt bij herhaling paniekaanvallen. Van een paniekaanval wordt gesproken als intense gevoelens van angst vrij onverwacht optreden, zonder een directe aanleiding. Deze paniekaanvallen gaan gepaard met minstens vier symptomen uit de volgende lijst: ademnood, duizeligheid, hartkloppingen, trillen of beven, transpireren, misselijkheid, depersonalisatie, pijn op de borst, angst om dood te gaan en/of angst om gek te worden of de controle over zichzelf te verliezen. Mensen met een paniekstoornis maken zich aanhoudend zorgen over het optreden van een volgende aanval of over de gevolgen van de aanvallen. De DSM-IV onderscheidt daarbij paniekstoornis zonder en paniekstoornis met agorafobie. Van agorafobie is sprake als iemand uit vrees voor nieuwe paniekaanvallen mensenmenigten mijdt en situaties waar men niet snel genoeg uit weg kan komen (bijvoorbeeld openbaar vervoer, bruggen, tunnels, ver van huis). Agorafobie kan optreden bij een paniekstoornis, maar ook zonder dat er sprake is van een paniekstoornis.

\section{Sociale fobie}

Iemand met een sociale fobie heeft een intense en irrationele angst voor het verkeren in het gezelschap van anderen, vooral als daar een prestatie van hem wordt verwacht. Hij is bang door anderen negatief te worden beoordeeld. Hij kan ook bang zijn voor zijn eigen reactie op de angst, zoals verlegenheid, blozen of trillen. De betrokkene probeert de gevreesde sociale situaties te vermijden. Als dat niet mogelijk is, doorstaat hij het met intense angst. De angst in sociale situaties en het vermijdingsgedrag verstoren zijn dagelijkse functioneren sterk.

\section{Samengaan van meerdere angststoornissen tegelijkertijd}

Mensen met een angststoornis hebben daarnaast vaak een andere angststoornis (Ravelli et al., 1998). Deze tweede angststoornis is vaak een specifieke en/of een sociale fobie; bij één op de drie mensen met een gegeneraliseerde angststoornis is dit het geval. Een kwart van de mensen met een gegeneraliseerde angststoornis lijdt ook aan een paniekstoornis. Een gegeneraliseerde angststoornis komt ook vaak voor als tweede diagnose. Ongeveer de helft van de mensen met een paniekstoornis heeft daarnaast ook agorafobie. Mensen met een specifieke fobie hebben daarnaast vaak ook een sociale fobie of paniekstoornis. Daarnaast gaan angststoornissen vaak samen met depressie en alcoholgerelateerde stoornissen.

\section{Beloop van angststoornissen}

De leeftijd waarop een angststoornis begint en de duur ervan loopt nogal uiteen tussen de verschillende stoornissen (Sytema et al., 1999). Het beloop kan zeer langdurig zijn; de kans op verbetering schommelt voor alle angststoornissen tussen de $20 \%$ en $30 \%$. Door de huisarts herkende angststoornissen hebben een kortere duur dan nietherkende angststoornissen. Geschat wordt dat een jaar na het ontstaan van de stoornis 
ongeveer 38\% van de mensen met een angststoornis herstelt. Er zijn verschillende factoren die de kans op herstel verkleinen: het gebruik van psychofarmaca in combinatie met een affectieve stoornis, veel depressieve symptomen in het verleden, veel angstsymptomen in het verleden, en weinig positieve gebeurtenissen. Hieronder wordt het beloop voor de verschillende angststoornissen nader beschreven.

\section{Gegeneraliseerde angststoornis}

Over het algemeen komt een gegeneraliseerde angststoornis het minst voor bij kinderen en jongeren en neemt het risico toe met de leeftijd. Over de eerste jaren van een gegeneraliseerde angststoornis is uit onderzoek weinig bekend, omdat laat behandeling wordt gezocht (Schoemaker \& De Ruiter, 2003). Gemiddeld duurt het zo'n tien jaar voordat hulp wordt ingeschakeld. Slechts één op de drie mensen zoekt hulp in het eerste jaar na het ontstaan van de stoornis. Eenmaal vastgesteld, heeft gegeneraliseerde angststoornis een chronisch verloop. Slechts 15\% heeft in een periode van één jaar langer dan twee maanden geen symptomen. Na twee jaar is een kwart volledig hersteld, na vijf jaar is dit bijna $40 \%$.

\section{Paniekstoornis}

Paniekstoornis openbaart zich in Nederland bij mannen gemiddeld op de leeftijd van 28 jaar en bij vrouwen rond 25 jaar (Schoemaker et al., 2002). Dit komt overeen met het beeld in andere westerse landen. Het risico op een paniekstoornis neemt af met de leeftijd. Over het exacte beloop van paniekstoornis zijn weinig gegevens voorhanden. Paniekaanvallen treden vaak met tussenpozen gedurende enkele jaren op. Na verloop van tijd kunnen ze minder frequent worden en zelfs ophouden, maar de kans op terugkeer is groot. Mensen die naast paniekstoornis ook agorafobie hebben, herstellen langzamer dan mensen met alleen paniekstoornis.

\section{Sociale fobie}

Sociale fobie openbaart zich in Nederland bij mannen gemiddeld op de leeftijd van 19 jaar en bij vrouwen rond 20 jaar (Schoemaker et al., 2002). Buitenlands onderzoek laat eenzelfde gemiddelde aanvangsleeftijd zien, of iets lager. Sociale fobie komt ook vaak op eerdere leeftijd voor. In Nederlands onderzoek onder kinderen en adolescenten werd een gemiddelde aanvangsleeftijd gevonden van 12 jaar. Sociale fobie duurt meestal tientallen jaren: de helft van de mensen met sociale fobie heeft het langer dan 25 jaar.

\section{Doelgroepen voor preventie}

Er bestaat niet één oorzaak van angststoornissen; het gaat altijd om een combinatie van elkaar beïnvloedende determinanten. De determinanten zoals die naar voren komen in epidemiologisch onderzoek zijn elders uitgebreid beschreven (Maas \& Jansen, 2000; Schoemaker \& De Ruiter, 2005). Hun onderlinge verbanden worden weergegeven in het Dynamisch Stress-Kwetsbaarheidsmodel (zie Maas \& Jansen, 2000; Witte, 2004). 
In deze paragraaf gaan we niet uitgebreid in op de afzonderlijke determinanten. We richten ons hier op concrete doelgroepen voor preventie. In deze doelgroepen komen meestal meerdere determinanten samen. Zoals beschreven in hoofdstuk 2 hanteren we bij het beschrijven van de doelgroepen de indeling in geïndiceerde, selectieve en universele preventie. Deze indeling moet niet al te strikt worden opgevat; verschillende doelgroepen zijn met verschillende vormen van preventie te benaderen. Daarnaast overlappen doelgroepen elkaar gedeeltelijk, waardoor sprake is van een extra hoog risico (Smit et al., 2006a).

\section{Geïndiceerde preventie}

De doelgroep voor geïndiceerde preventie bestaat uit mensen met angstklachten, die (nog) niet voldoen aan de diagnose voor een angststoornis. Zij lopen immers een sterk verhoogde kans om een angststoornis te ontwikkelen (Batelaan et al., 2006). Deze klachten zijn overigens niet altijd eenvoudig te herkennen als angstklachten: vaak worden ze gepresenteerd als spanningklachten of werkgerelateerde stressklachten. De doelgroepen waar geïndiceerde preventieve interventies zich in de praktijk meestal op richten zijn mensen met sociale angst of paniekklachten, of mensen die zeer veel piekeren. Dit zijn de klachten die zouden kunnen leiden tot een sociale fobie, een paniekstoornis of een gegeneraliseerde angststoornis.

\section{Selectieve preventie}

Voor selectieve preventie zijn in de praktijk de volgende drie specifieke doelgroepen van belang:

- Kinderen van ouders met een psychische stoornis. Zij hebben bijna driemaal zoveel kans om een angststoornis te krijgen als kinderen van andere ouders (Beardslee et al., 2003). Dit komt allereerst door een genetisch bepaalde kwetsbaarheid. Daarnaast hebben deze kinderen echter ook te kampen met extra stress door de problemen die een psychisch ongezonde ouder met zich meebrengt. Bovendien zijn ze in sociaal opzicht extra kwetsbaar omdat de psychische problemen van de ouders hoogstwaarschijnlijk ook zullen doorwerken op opvoeding van deze kinderen.

- Mensen met specifieke fobie. Specifieke fobie is de meest voorkomende angststoornis. Preventieve interventies voor de specifieke fobie zijn echter buiten beschouwing gelaten, omdat hiervoor onvoldoende wetenschappelijke kennis is. Een fobie kan een eerste stap zijn in het ontwikkelen van een andere angststoornis.

- Jongeren met problemen in sociale contacten. Mensen met weinig sociale vaardigheden hebben meer kans om een sociale fobie te ontwikkelen. De meeste nieuwe gevallen van sociale fobie komen voor bij de leeftijdsgroep jongeren. Bij hen kunnen normale angstgevoelens worden versterkt door de sociale eisen in de puberteit, wat uiteindelijk kan leiden tot een sociale fobie (Schoemaker et al., 2002).

\section{Universele preventie}

Onderstaande groepen hebben een verhoogd risico op het ontwikkelen van een psychische stoornis, waaronder een angststoornis:

- Jongeren. Jongeren zijn op basis van hun leeftijd vooral een geschikte doelgroep voor universele preventie van psychische stoornissen, waaronder een angststoor- 
nis. Uit onderzoek is gebleken dat mensen met weinig sociale vaardigheden een verhoogde kans hebben om een sociale fobie te ontwikkelen. Meer algemeen is een inadequate manier van omgaan met stressvolle situaties (coping) een risicofactor voor het ontwikkelen van een psychische stoornis. Door jongeren in een vroeg stadium sociaal-emotionele vaardigheden eigen te maken om adequaat om te gaan met stressvolle situaties, zijn ze in hun latere leven mogelijk beter beschermd tegen het ontwikkelen van een angststoornis of een andere psychische stoornis.

- Volwassen vrouwen. Vrouwen hebben een tweemaal zo grote kans op een angststoornis als mannen. Bovendien is de incidentie van een angststoornis het hoogst bij volwassenen (Van Balkom et al., 2005b).

- Allochtonen. Ook bij deze groep komen meerdere risicofactoren samen. Deze groepen hebben vaker dan gemiddeld slechte sociaal-economische omstandigheden, en hebben een verhoogd risico op gebrek aan sociale steun. Ze kunnen zich bijvoorbeeld geïsoleerd voelen als ze de Nederlandse taal nog niet goed beheersen of zich nog niet thuis voelen in de Nederlandse cultuur.

- Mensen met een lage sociaal-economische status. Deze mensen hebben vaak te kampen met een combinatie van risicofactoren, zoals stressvolle (sociaal-economische) levensomstandigheden of een ongezonde leefstijl. Specifieke groepen van mensen met een lage sociaal-economische status zijn bijvoorbeeld terug te vinden in achterstandswijken of onder langdurig werklozen. Ook vluchtelingen verkeren vaak in slechte sociaal-economische omstandigheden. Zij lopen extra risico op een psychische stoornis omdat bij hen meestal ook andere risicofactoren aanwezig zijn, zoals een geschiedenis van traumatische of stressvolle ervaringen en een gebrek aan sociale steun. Dit geldt specifiek voor minderjarige alleenstaande asielzoekers.

- Mensen met weinig sociale steun. Specifieke groepen die vaak te kampen hebben met een gebrek aan sociale steun zijn bijvoorbeeld ouderen en weduwen (Schoevers et al., 2006).

- Ouderen. Bij ouderen komen angststoornissen naar verhouding vaker voor dan bij volwassenen, met name de gegeneraliseerde angststoornis. Maar liefst één op de negen (11\%) van de ouderen lijdt aan een gegeneraliseerde angststoornis (Bremmer et al., 1997; Smit et al., in druk-a).

\subsection{Omvang, ernst en gevolgen van angststoornissen}

De onderstaande cijfers over omvang, ernst en gevolgen van angststoornissen hebben betrekking op álle angststoornissen, inclusief de angststoornissen die niet tot de focus van de preventieve interventies binnen dit themarapport behoren.

\section{Jaarprevalentie}

Angststoornissen komen veel voor. Per jaar lijdt naar schatting één op de acht mensen (12,5\%) aan enige angststoornis. Dat zijn ongeveer 1,7 miljoen mensen in heel Nederland. De angststoornissen die daarbij meegerekend zijn staan per leeftijdsgroep vermeld in tabel 4.1. Per jaar lijdt ongeveer één op de negen jongeren tussen dertien en zeventien jaar $(11,6 \%)$ volgens eigen zeggen aan enige angststoornis. In totaal gaat 
het dan om ongeveer 114 duizend jongeren $13 \mathrm{t} / \mathrm{m} 17$ jaar met een angststoornis in Nederland (Verhulst et al., 1997). Daarbij komt de specifieke en de sociale fobie relatief vaak voor. Een paniekstoornis is vrij zeldzaam bij jongeren. Bij volwassenen komen angststoornissen ongeveer evenveel voor als bij jongeren. Per jaar lijdt ongeveer één op de acht volwassenen (12,3\%) aan een angststoornis. Evenals bij jongeren komen de specifieke fobie $(7,1 \%)$ en de sociale fobie $(4,7 \%)$ het meest voor (Bijl et al.,1998; tabel 4.1). In totaal gaat het om bijna 1,3 miljoen volwassenen. Bij ouderen komen angststoornissen iets vaker voor dan bij mensen jonger dan 65 jaar. Per jaar lijdt ongeveer één op de zeven ouderen (14,1\%) aan een angststoornis. Dit zijn ongeveer 314 duizend ouderen. De gegeneraliseerde angststoornis komt in deze leeftijdsgroep in verhouding zeer veel voor: maar liefst één op de negen (11\%) van de ouderen lijdt eraan (Bremmer et al., 1997). Dat zijn 254 duizend mensen.

Tabel 4.1: Jaarprevalentie van angststoornissen, uitgesplitst naar type stoornis per leeftijdsgroep (\%).

\begin{tabular}{|c|c|c|c|c|}
\hline & Jongeren $^{\mathrm{a}}$ & Volwassenen $^{\mathrm{b}}$ & Ouderen ${ }^{c}$ & Totaal \\
\hline Angststoornissen totaal ${ }^{d}$ & 11,6 & 12,3 & 14,1 & 12,5 \\
\hline gegeneraliseerde angst & 0,8 & 1,2 & 11,4 & 2,8 \\
\hline paniekstoornis & 0,1 & 2,2 & 1,3 & 1,9 \\
\hline agorafobie & 0,8 & 1,6 & 1 & 1 \\
\hline sociale fobie & 4,0 & 4,7 & 3,6 & onbekend \\
\hline specifieke fobie & 5,0 & 7,1 & J & J \\
\hline obsessief-compulsief & 1,1 & 0,4 & 1,4 & 0,7 \\
\hline separatie-angst & $1,4^{\mathrm{e}}$ & n.v.t. & n.v.t. & n.v.t. \\
\hline vermijdingsangst & $1,4^{\mathrm{e}}$ & n.v.t. & n.v.t. & n.v.t. \\
\hline overmatige angststoornis & $1,8^{\mathrm{e}}$ & n.v.t. & n.v.t. & n.v.t. \\
\hline
\end{tabular}

a $13 \mathrm{t} / \mathrm{m} 17$ jaar (Verhulst et al., 1997).

b 18 t/m64 jaar (Bijl et al., 1997a).

c 65+ jaar (Bremmer et al., 1997).

d De cijfers voor 'angststoornissen totaal' zijn gebaseerd op alle in de tabel vermelde specifieke angststoornissen. Dit verschilt per leeftijdsgroep.

e 6-maandsprevalentie (jaarprevalentie onbekend). Deze stoornissen zijn alleen bij kinderen en jongeren gediagnosticeerd.

\section{Incidentie}

Uit de Nemesis-studie blijkt dat per jaar ongeveer een kwart van de volwassenen met een angststoornis hier voor het eerst aan lijdt (322 duizend volwassenen; Bijl et al., 1997a; tabel 4.2). Incidentiecijfers voor jongeren en ouderen ontbreken. Wel is er recent Amerikaans onderzoek, waaruit blijkt dat een kwart van de mensen die ooit in hun leven een angststoornis hebben gehad, dit voor het eerst ontwikkelt tussen de 11 en 21 jaar (Kessler et al., 2005). Slechts één op de honderd mensen met een angststoornis krijgt dit voor het eerst pas na zijn $65^{\mathrm{e}}$ jaar. Als we deze cijfers extrapoleren naar Nederland gaat het voor de hele Nederlandse bevolking om ongeveer 463 duizend nieuwe gevallen van enige angststoornis per jaar (bijlage 2). 


\section{Ziektelast (in DALY's)}

De gemiddelde wegingsfactor voor angststoornissen is voor jongeren (13 t/m 17 jaar), volwassenen (18 t/m 64 jaar) en ouderen (65+ jaar) dezelfde: 0,17 (bijlage 2). Daarmee staan angststoornissen in totaal gelijk aan 227 duizend ziektejaarequivalenten (tekstblok 1.1). Over het algemeen gaat een angststoornis niet gepaard met een verhoogde kans op vroegtijdige sterfte of suïcide. Een uitzondering hierop vormt de gegeneraliseerde angststoornis. Van de mensen met een gegeneraliseerde angststoornis die worden behandeld in de eerste lijn, denkt bijna de helft regelmatig aan suïcide (Schoemaker \& De Ruiter, 2003). Van de mensen met een bijkomende depressie is dat zelfs twee derde. Onbekend is hoeveel mensen met een gegeneraliseerde angststoornis daadwerkelijk suïcide pleegt. Volgens het Centraal Bureau voor de Statistiek (CBS) is het aantal verloren levensjaren door angststoornissen te verwaarlozen: het gaat slechts om 48 verloren levensjaren (De Hollander et al., 2006). Gezien het verhoogde risico op suïcide is dit een onderschatting.

Uitgaande van het lage CBS-cijfer voor sterfte is het totale aantal DALY's voor angststoornissen ongeveer gelijk aan het aantal ziektejaarequivalenten: minimaal 227 duizend (tabel 4.2). Daarin is geen rekening gehouden met het feit dat veel mensen meer dan één angststoornis tegelijkertijd hebben. Bij hen zal de kwaliteit van leven lager zijn dan bij degenen die 'slechts' één angststoornis hebben (bijlage 2). De ziektelast voor het aantal nieuwe gevallen van angststoornissen bedroeg ruim ongeveer 53 duizend DALY’s per jaar (tabel 4.2).

\section{Zorggebruik}

Van de volwassenen met een angststoornis maakt per jaar minder dan de helft (41\%) gebruik van enigerlei zorg. Een derde deel van hen bezoekt de eerstelijn, ongeveer $18 \%$ bezocht de ambulante GGZ. Een kleine $2 \%$ van de mensen met een angststoornis wordt opgenomen in de GGZ (Bijl \& Ravelli, 1998). Dergelijke zorggebruikcijfers over jongeren en ouderen zijn niet bekend. Van ouderen is bekend welk deel van hen door de huisarts behandeld is met medicatie die met de angststoornis te maken kan hebben: $4 \%$ is binnen een half jaar voor de peiling behandeld met antidepressiva en 25\% met benzodiazepines. Drie procent heeft binnen een half jaar voor de peiling een psychiater gezien, 3\% een maatschappelijk werker en $4 \%$ heeft een RIAGG bezocht (De Beurs et al., 1999).

\section{Zorgkosten}

In 2003 werd zo'n 275 miljoen euro uitgegeven aan zorgkosten samenhangend met angststoornissen (Slobbe et al., 2006; tabel 4.2). Dat is ongeveer 0,5\% van het totaal van 57,5 miljard aan zorgkosten, en ongeveer $2 \%$ van de 12,6 miljard euro die wordt besteed aan de zorg voor mensen met psychische stoornissen. Twee derde van de zorgkosten voor angststoornissen (181 miljoen) werd besteed aan vrouwen, en eenderde aan mannen (94 miljoen). De Kosten van Ziekten-studie laat geen uitsplitsing naar type angststoornis toe. 
Een klein deel van deze 275 miljoen euro - ongeveer 18 miljoen - ging naar kinderen en jongeren tussen 0 en 19 jaar. Het overgrote deel - bijna 223 miljoen (81 \%) - werd besteed aan de zorg voor volwassenen tussen 20 en 64 jaar. Ongeveer 35 miljoen euro ging naar de zorg voor ouderen met een angststoornis (13\%). Qua kosten is de leeftijdsgroep 25 tot 45 jaar flink oververtegenwoordigd: 43\% van alle zorgkosten voor angststoornissen kwam terecht in deze leeftijdgroep: 76 miljoen voor de vrouwen en 43 miljoen voor de mannen.

Voor een schatting van de incidente kosten van angststoornissen hebben we gebruik gemaakt van een andere kosten-van ziektenstudie, op basis van Nemesis (Smit et al., in druk-b; tekstblok 2.1). Deze studie geeft onder andere een schatting van de directe zorgkosten voor volwassenen bij angststoornissen. De zorgkosten voor het aantal nieuwe gevallen van angststoornissen bij volwassenen bedroegen in 2003 bijna 87 miljoen euro (tabel 4.2).

\section{Ziekteverzuim en kosten van ziekteverzuim}

De kans op ziekteverzuim bij mannen met een angststoornis is groter dan bij mannen zonder angststoornis. Voor vrouwen is het verschil niet significant: vrouwen met een angststoornis verzuimen niet meer dan vrouwen zonder angststoornis (Laitinen-Krispijn \& Bijl, 2002).

De jaarlijkse kosten als gevolg van productieverlies door ziekteverzuim bij angststoornissen zijn ruim 3 duizend euro per hoofd van de volwassen bevolking (Smit et al., in druk-b). Bij een aantal van ruim 1 miljoen volwassenen met een angststoornis is dit jaarlijks gemiddeld bijna 4 miljard euro (tabel 4.2). Er wordt grofweg 46 miljoen euro besteed aan gegeneraliseerde angststoornis, 1,5 miljard aan paniekstoornis, 1 miljard aan sociale fobie, 520 miljoen aan agorafobie, en 1,5 miljard euro aan specifieke fobieën. De kosten van de afzonderlijke stoornissen bij elkaar opgeteld zijn overigens hoger dan de gemiddelde totale kosten bij mensen met 'een angststoornis' omdat veel mensen meer dan één angststoornis hebben en bij de afzonderlijke stoornissen dus vaker meetellen. De jaarlijkse kosten als gevolg van ziekteverzuim bij de nieuwe gevallen van angststoornissen bedroegen 999 miljoen euro.

\section{Arbeidsongeschiktheid}

Van de 992 duizend arbeidsongeschikten in 2002 hadden slechts 16 duizend van de verzekeringsarts de diagnose 'angststoornis' gekregen (1,6\%; tabel 4.2) (Uitvoering Werknemersverzekeringen, UWV, 2002). Bijna tweederde hiervan was vrouw. Van de 358 duizend arbeidsongeschikten met een diagnose binnen de hoofdgroep psychische stoornissen is dat ongeveer één op de vijfentwintig. Het overgrote deel van deze 16 duizend - 15 duizend - zat in de WAO, de rest zat in de WAZ en de WAJONG (bijlage 2). Ongeveer drie kwart van de mensen in de WAO was volledig arbeidsongeschikt. Van de 108 duizend nieuwe arbeidsongeschikten in 2002 kregen een kleine 2 duizend (2\%) een angststoornis als diagnose. Binnen de groep van 40 duizend nieuwe gevallen met een psychische diagnose nemen angststoornissen een bescheiden plaats in (ongeveer 5\%). De instroom (bijna 2 duizend) was in 2002 iets hoger dan de uitstroom (ruim 1.500). 
Tabel 4.2: Angststoornissen: omvang, ernst en gevolgen per jaar ${ }^{a}$.

\begin{tabular}{|c|c|c|c|c|}
\hline & Jongeren & Volwassenen & Ouderen & Totaal \\
\hline \multicolumn{5}{|l|}{ Prevalente gevallen } \\
\hline \multicolumn{5}{|l|}{ Omvang } \\
\hline \multicolumn{5}{|l|}{ Jaarprevalentie ${ }^{b}$} \\
\hline$\%$ & 11,6 & 12,3 & 14,1 & 12,5 \\
\hline aantal & 113.500 & 1.272 .800 & 314.300 & 1.700 .700 \\
\hline \multicolumn{5}{|l|}{ Ernst en gevolgen } \\
\hline \multicolumn{5}{|l|}{ Ziektelast b } \\
\hline \multicolumn{5}{|l|}{ Kosten } \\
\hline zorgkosten (in mln euro) d & 17,6 & 222,9 & 34,8 & 275,2 \\
\hline kosten door ziekteverzuim ${ }^{\mathrm{e}}$ & - & $3.945,7$ & - & - \\
\hline Arbeidsongeschiktheid ${ }^{\mathrm{f}}$ & - & 16.000 & - & - \\
\hline \multicolumn{5}{|l|}{ Incidente gevallen } \\
\hline \multicolumn{5}{|l|}{ Omvang } \\
\hline \multicolumn{5}{|l|}{ Incidentie } \\
\hline \multicolumn{5}{|l|}{ Ernst en gevolgen } \\
\hline \multicolumn{4}{|l|}{ Ziektelast ${ }^{\mathrm{b}}$} & 52.500 \\
\hline \multicolumn{5}{|l|}{ Kosten $^{\mathrm{i}}$} \\
\hline zorgkosten (in mln euro) & - & 86,7 & - & - \\
\hline kosten door ziekteverzuim & - & 998,8 & - & - \\
\hline
\end{tabular}

${ }^{a}$ Het gaat hierbij om álle angststoornissen, inclusief de angststoornissen die niet tot de focus van de preventieve interventies binnen dit themarapport behoren.

b Leeftijdsgroepen: 13-17 (Verhulst et al., 1997), 18-64 (Bijl et al., 1997) en 65+ (Bremmer et al., 1997).

c Wegingsfactor voor angststoornissen $=0,17$; ziekteduur $=8 \mathrm{mnd}$, zie voor een berekening tekstblok 1.1.

${ }^{d}$ Leeftijdsgroepen: 0-19, 20-64, 65+ (Slobbe et al., 2006).

e Prevalent verzuim volwassenen 18t/m64 jaar, gebaseerd op gegevens uit 2003 (Smit et al., in druk-b).

f Prevalente gevallen, gebaseerd op gegevens uit 2002 (UWV, 2002).

$\mathrm{g}$ Incidentie afgeleid van lifetime prevalentie (Kessler et al., 2005), in relatie tot incidentiecijfers van Nemesis (Bijl et al., 2002); zie voor een berekening bijlage 2. Deze cijfers zijn hoger dan op grond van de prevalentie-aantallen verwacht zou worden.

h Incidentie-aantallen per stoornis: gegeneraliseerde angst $=79.100$, paniekstoornis $=80.000$, sociale fobie $=99.900$, agorafobie zonder paniek $=83.700$, specifieke fobie $=232.200$.

i Incidente kosten volwassenen 18-64, gebaseerd op gegevens uit 2003 (Smit et al., in druk-b).

Het geregistreerde aantal arbeidsongeschikten als gevolg van een angststoornis is waarschijnlijk een onderschatting van de werkelijkheid. Angststoornissen worden namelijk vaak niet herkend door hulpverleners. Daarnaast hebben mensen met een angststoornis vaak ook een bijkomende depressie. Een aantal van hen zal daarom onder de diagnose depressie als arbeidsongeschikt geregistreerd worden.

\section{Omvang, ernst en gevolgen van angststoornissen samengevat}

Jaarlijks zijn er 1,7 miljard mensen met een angststoornis; zij vertegenwoordigen ruim 227 duizend DALY's (tabel 4.2). De directe zorgkosten van angststoornissen bedragen jaarlijks ruim 275 miljoen euro. Daarnaast genereren volwassenen 3,9 miljard euro aan kosten als gevolg van ziekteverzuim door angststoornissen. Het aantal nieuwe gevallen 
van angststoornissen bedraagt jaarlijks naar schatting ruim 463 duizend mensen; zij vertegenwoordigen ongeveer 53 duizend DALY's. De zorgkosten voor nieuwe gevallen van angststoornissen bij volwassenen bedragen jaarlijks zo'n 87 miljoen euro; daarnaast genereren deze volwassenen ongeveer 999 miljoen euro aan kosten als gevolg van ziekteverzuim. In hoeverre deze omvang, ernst en gevolgen kunnen worden gereduceerd met behulp van preventie, hangt af van de beschikbaarheid van effectieve interventies en het bereik daarvan. Dat is het onderwerp van de volgende paragrafen.

\subsection{Preventieve interventies voor angststoornissen bij jongeren}

In deze paragraaf geven we een samenvatting van de in Nederland beschikbare preventieve interventies voor angststoornissen bij jongeren. In paragraaf 4.3.1 komen de in Nederland beschikbare interventies aan bod. De interventies zijn ingedeeld in universele, selectieve en geïndiceerde preventie (hoofdstuk 2). Aan het eind van deze paragraaf staat een tabel met alle beschikbare interventies ter preventie van angststoornissen bij jongeren (tabel 4.3). Paragraaf 4.3.2 beschrijft gezondheidseffecten van die interventies die in een gerandomiseerde studie geëvalueerd zijn, inclusief conclusies over de behaalbare gezondheidswinst. Voor een uitgebreide beschrijving van de in Nederland beschikbare interventies ter preventie van angststoornissen bij jongeren verwijzen we naar bijlage 4 . Voor een uitleg van de beoordeling op wetenschappelijke status en ontwikkelingsfase verwijzen we naar paragraaf 2.4 .

\subsubsection{In Nederland beschikbare preventieve interventies voor angststoornissen bij jongeren}

\section{Universele preventie van angststoornissen bij jongeren}

Angst en depressie bij jongeren worden in de literatuur vaak onder één noemer gebracht als 'internaliserende problematiek'. Universele preventie van internaliserende problemen bij jongeren - waaronder angst, maar ook depressie - bestaat ondermeer uit het geven van psycho-educatieve voorlichting. Daarnaast krijgen leerlingen op scholen vaardigheidstrainingen, waarin algemene sociale vaardigheden of het omgaan met stress, worden aangeleerd. De algemene sociale vaardigheidstrainingen zijn beschreven in paragraaf 3.3.1. De trainingen die zich specifiek richten op angst worden hieronder beschreven. Voor een uitgebreide beschrijving van deze programma's zie bijlage 4.

- 'Voorlichtingsbijeenkomsten' hebben tot doel om voorlichting te geven aan groepen over veel voorkomende psychiatrische ziektebeelden bij jongeren en het bijbehorende zorgaanbod. De bijeenkomsten zijn gericht op jongeren, ouders en andere betrokkenen zoals leerkrachten en huisartsen die meer willen weten over psychiatrische ziektebeelden bij jongeren.

Ontwikkelingsfase: onbekend. Wetenschappelijke status: onbekend. 
- 'Voorlichtingsbijeenkomst voor (alleenstaande) minderjarige asielzoekers' biedt asielzoekers handvatten over het omgaan met psychische problemen, waaronder angst.

Ontwikkelingsfase: I. Wetenschappelijke status: onbekend.

- De cursus 'Vrienden' (groepsversie en individuele versie; NIZW, 2005) is geschikt voor universele, selectieve en geïndiceerde preventie, en staat beschreven bij 'geïndiceerde preventie bij jongeren'.

Ontwikkelingsfase: G. Wetenschappelijke status: onbekend bij een universele doelgroep.

\section{Selectieve preventie van angststoornissen bij jongeren}

- Het programma 'Plezier op school' (Geerlings \& Lissenburg, 2005) is gebaseerd op cognitieve gedragstherapeutische technieken, gecombineerd met ontspanningstechnieken. De interventie richt zich op beginnende brugklassers (12-14 jaar) die problemen hebben met sociale contacten. Dit zijn kinderen die het slachtoffer zijn van pesterijen, angstig, vermijdend of onhandig zijn in contact met leeftijdsgenoten. Het programma bestaat uit een tweedaagse training in de week voordat de jongere naar de brugklas gaat. Er zijn aanwijzingen dat het programma effecten heeft op sociale angst en op gepest worden (Geerlings \& Lissenburg, 2005). Ontwikkelingsfase: I. Wetenschappelijke status: *.

- De cursus 'Vrienden' (NIZW, 2005) is geschikt voor universele, selectieve en geïndiceerde preventie, en staat hieronder beschreven bij 'geïndiceerde preventie bij jongeren'.

Ontwikkelingsfase: G. Wetenschappelijke status: onbekend bij een selectieve doelgroep.

\section{Geïndiceerde preventie van angststoornissen bij jongeren}

- De cursus 'Vrienden' (NIZW, 2005) is een Nederlandse bewerking van het programma 'Friends' uit Australië. De cursus is geschikt voor universele, selectieve en geïndiceerde preventie. Hier wordt het deel beschouwd dat betrekking heeft op geïndiceerde preventie. De cursus richt zich op jongeren tussen de 12 en 16 jaar die al milde symptomen van angst hebben. Er is overigens ook een versie voor jongere kinderen van 7 tot en met 11 jaar. Het programma kan in groepsverband of individueel worden aangeboden. Deze interventie is bij kinderen van 10-13 jaar in het buitenland effectief bevonden (paragraaf 4.3.4). De effectiviteit is minder vaak onderzocht bij jongeren, maar in een buitenlandse gerandomiseerde studie is ook bij deze doelgroep een significante afname van angstklachten gevonden (Barrett et al., 2001). Momenteel loopt er een Nederlands gerandomiseerd onderzoek naar de effecten van deze interventie bij kinderen en jongeren. De resultaten worden verwacht in 2006.

Ontwikkelingsfase: G. Wetenschappelijke status: **.

- Het programma 'Plezier op school’ (Geerlings \& Lissenburg, 2005) richt zich behalve op risicogroepen die nog geen angstklachten hebben (zie selectieve preventie van angststoornissen bij jongeren) ook op jongeren die al angstklachten hebben.

Ontwikkelingsfase: I. Wetenschappelijke status: *. 
Tabel 4.3: Overzicht van in Nederland beschikbare interventies ter preventie van angststoornissen bij jongeren.

\begin{tabular}{|c|c|c|c|c|c|}
\hline & $\begin{array}{l}\text { Soort } \\
\text { interventie }^{a}\end{array}$ & $\begin{array}{l}\text { Ontwikke- } \\
\text { lingsfase }^{b}\end{array}$ & $\begin{array}{l}\text { Wetensch. } \\
\text { status }^{c}\end{array}$ & $\begin{array}{l}\text { Uitkomst- } \\
\text { maat }^{\mathrm{d}}\end{array}$ & Doelgroep \\
\hline \multicolumn{6}{|l|}{ Universeel } \\
\hline $\begin{array}{l}\text { Voorlichtings- } \\
\text { bijeenkomsten }\end{array}$ & $\begin{array}{l}\text { groeps- } \\
\text { bijeenkomst }\end{array}$ & I & onbekend & - & $\begin{array}{l}\text { jongeren, ouders } \\
\text { en andere betrok- } \\
\text { kenen (leerkrach- } \\
\text { ten, huisartsen) }\end{array}$ \\
\hline $\begin{array}{l}\text { Voorlichtingsbijeen- } \\
\text { komsten minder- } \\
\text { jarige asielzoekers }\end{array}$ & $\begin{array}{l}\text { groeps- } \\
\text { bijeenkomst }\end{array}$ & I & onbekend & - & $\begin{array}{l}\text { alleenstaande } \\
\text { minderjarige } \\
\text { asielzoekers }\end{array}$ \\
\hline Vrienden & $\begin{array}{l}\text { groep / } \\
\text { individueel }\end{array}$ & G & $\begin{array}{l}\text { onbekend } \\
\text { bij } \\
\text { universeel }\end{array}$ & & jongeren $12-16$ jr \\
\hline \multicolumn{6}{|l|}{ Selectief } \\
\hline Plezier op school & groep & I & * & - & $\begin{array}{l}\text { brugklassers } \\
12-14 \text { jr met } \\
\text { sociale problemen }\end{array}$ \\
\hline Vrienden & $\begin{array}{l}\text { groep / } \\
\text { individueel }\end{array}$ & G & $\begin{array}{l}\text { onbekend } \\
\text { bij selectief }\end{array}$ & & jongeren $12-16$ jr \\
\hline \multicolumn{6}{|l|}{ Geïndiceerd } \\
\hline Vrienden & groep & G & ** & $\mathrm{K}$ & jongeren $12-16$ jr \\
\hline Plezier op school & groep & I & $*$ & - & $\begin{array}{l}\text { brugklassers } \\
12-14 \text { jr met } \\
\text { sociale problemen }\end{array}$ \\
\hline Zo gek nog niet & internet & G & onbekend & & jongeren \\
\hline $\begin{array}{l}\text { Buitenland: } \\
\text { Angstmanagement- } \\
\text { training }\end{array}$ & groep & B & $* *$ & $\mathrm{~K}$ & $\begin{array}{l}\text { scholieren laatste } \\
\text { klas VO }\end{array}$ \\
\hline $\begin{array}{l}\text { Buitenland: Stress } \\
\text { inoculation training }\end{array}$ & groep & B & ** & $\mathrm{K}$ & $\begin{array}{l}\text { scholieren laatste } \\
\text { klas VO (16-19 jr) }\end{array}$ \\
\hline
\end{tabular}

a Soort interventie: Groep = groepscursus. Internet $=$ internetcursus (paragraaf 2.3).

b Ontwikkelingsfase: I = innovatief, G = gestandaardiseerd ('good practice'), B = buitenlands (paragraaf 2.3).

c Wetenschappelijke status: ${ }^{*}=$ gepubliceerde mening van deskundigen, of mening van werkgroepleden,

** = gebaseerd op één gerandomiseerde trial of meerdere onderzoeken zonder controlegroep (paragraaf

2.4).

d Uitkomstmaat: $\mathrm{K}=$ effect op klachten (paragraaf 2.4 ).

- Bij de website 'Zo gek nog niet' (www.zogeknogniet.nl, Stichting Pandora) kunnen jongeren terecht om informatie te krijgen of vragen te stellen over hun psychische problemen. Het is een site die zich naast algemene psychische klachten richt op angstklachten.

Ontwikkelingsfase: G. Wetenschappelijke status: onbekend.

Daarnaast zijn er nog twee interventies voor jongeren die (nog) niet in Nederland worden aangeboden, maar die wel een goede aanvulling zouden kunnen zijn op het huidige Nederlandse aanbod: de 'Angstmanagementtraining (Hains, 1992) en de 'Stress- 
inoculation training (Kiselica et al., 1994). Deze interventies zijn in het buitenland effectief gebleken (paragraaf 4.3.4). Er zijn overigens meer van dit soort interventies in het buitenland, maar ter illustratie beschrijven we slechts deze twee.

- De 'Angstmanagementtraining' (Hains, 1992). Deze training is gebaseerd op de cognitieve gedragstherapie en richt zich op scholieren in de laatste klas van het middelbaar onderwijs die zich voorbereiden op het hoger onderwijs. De interventies hebben tot doel het verminderen van angst en stress en versterken van het zelfvertrouwen. Deze interventie is effectief bevonden in een buitenlandse gerandomiseerde studie (paragraaf 4.3.4).

Ontwikkelingsfase: B. Wetenschappelijke status: ${ }^{* *}$.

- De 'Stress-inoculation training' (Kiselica et al., 1994) richt zich op jongeren (16-19 jaar) aan einde van de middelbare school met stress- en angstklachten. De training is gebaseerd op een combinatie van ontspanningsoefeningen, cognitieve herstructurering en assertiviteitstraining. Het doel is angst en stressklachten te verminderen, verbeteren van schoolprestaties en het aanleren van goed gedoceerde assertiviteit. Deze interventie is in een gerandomiseerde studie onderzocht. De resultaten ervan staan beschreven in paragraaf 4.3.4.

Ontwikkelingsfase: B. Wetenschappelijke status: **.

\subsubsection{Gezondheidseffecten van preventie van angststoornissen bij jongeren}

Van de bovenbeschreven interventies die in Nederland beschikbaar zijn, is er één onderzocht in een - buitenlandse - gerandomiseerde studie: de groepscursus 'Vrienden'. Daarnaast zijn van de twee beschreven buitenlandse interventies resultaten van een gerandomiseerde studie bekend: de 'Angstmanagementtraining' en de 'Stress-inoculation training'. We bespreken deze drie buitenlandse studies om iets te kunnen zeggen over de haalbare gezondheidswinst met dit type interventie.

\section{'Vrienden'}

De cursus 'Vrienden' (NIZW, 2005) is een Nederlandse bewerking van het programma 'Friends' uit Australië. In Australië werd een gerandomiseerde studie onder kinderen (10-13 jaar) uitgevoerd (Lowry-Webster et al., 2001). Geëvalueerd werd in hoeverre de kans op het krijgen van een angststoornis onder invloed van de interventie gereduceerd wordt. De aan- of afwezigheid van angst werd gemeten met de Spence Children’s Anxiety Scale (SCAS; Spence, 1997) waarmee separatieangst, sociale fobie, paniekstoornis, agorafobie en generaliseerde angststoornis wordt gemeten. De resultaten zijn weergegeven in tabel 4.4 .

De data leiden tot de conclusie dat het om een statistisch significante $(\mathrm{p}<0,05)$, effectieve $(\mathrm{RR}=0,45)$ en efficiënte $(\mathrm{NNT}=3,3)$ preventievorm gaat, voor zover het kinderen betreft. Het is onbekend hoe effectief deze interventie zou zijn bij jongeren van 13-18 jaar. Een latere follow-up studie laat zien dat het effect ook na een jaar behouden blijft (Lowry-Webster et al., 2003). Dit is in overeenstemming wat Dadds et al. (1997) al eerder vonden bij jongere kinderen. 
Tabel 4.4: Effectiviteit van 'Vrienden' op de incidentie van enige angststoornis bij kinderen 10-13 jaar $^{a}$.

\begin{tabular}{|c|c|c|c|c|}
\hline & & & $\begin{array}{l}\text { Interventiegroep } \\
\qquad(\mathrm{n}=77)\end{array}$ & $\begin{array}{c}\text { Controlegroep } \\
(n=31)\end{array}$ \\
\hline Kreeg stoornis & & & 19 & 17 \\
\hline Bleef stoornisvrij & & & 58 & 14 \\
\hline \multirow[t]{2}{*}{ Risico op de stoornis } & & & 0,25 & 0,55 \\
\hline & & $95 \%$ BI & & \\
\hline Risicoverschil (RV) & 0,30 & $(-0,10 \sim 0,50)$ & & \\
\hline Relatief risico (RR) & 0,45 & $(0,27 \sim 0,75)$ & & \\
\hline NNT & 3,3 & & & \\
\hline
\end{tabular}

$\chi^{2}=9,05, \mathrm{p}=0,00$

${ }^{a}$ Lowry-Webster et al., 2001; voor een uitleg van de tabel zie tekstblok 2.3.

Tabel 4.5: Effectiviteit van angstmanagementtraining bij jongeren op klachtenreductie $\left(S T A I^{a}\right)^{b}$.

\begin{tabular}{|c|c|c|c|c|}
\hline & & & $\begin{array}{l}\text { Interventiegroep } \\
\qquad(\mathrm{n}=9)\end{array}$ & $\begin{array}{c}\text { Controlegroep } \\
\qquad(\mathrm{n}=12)\end{array}$ \\
\hline Pre: M (Sd) & & & $42,0(8,5)$ & $46,8(12,6)$ \\
\hline Post: M & & & 34,3 & 52,4 \\
\hline \multirow[t]{2}{*}{ Pre-post: d } & & & 0,91 & $-0,45$ \\
\hline & & $95 \% \mathrm{BI}$ & & \\
\hline$\Delta(\mathrm{d})$ & 1,35 & $(0,48 \sim 2,22)$ & & \\
\hline AUC & 0,83 & $(0,62 \sim 0,94)$ & & \\
\hline Risicoverschil (RV) & 0,66 & $(0,25 \sim 0,88)$ & & \\
\hline NNT & 1,5 & & & \\
\hline
\end{tabular}

a State-Trait Anxiety Inventory (Spielberger, 1983).

b Hains et al., 1992; voor een uitleg van deze tabel zie tekstblok 2.3.

\section{Buitenlandse interventie: Angstmanagementtraining}

Hains en collega's (1992) onderzochten deze interventie in een gerandomiseerd effectonderzoek. De afname in angstklachten werd gemeten met de State-Trait Anxiety Inventory (STAI; Spielberger, 1983). De resultaten zijn weergegeven in tabel 4.5.

De angst van jongeren in de interventiegroep verbeterde ten opzichte van de wachtlijstcontrolegroep met 1,35 standaard eenheden. Dit moet gezien worden als een groot effect, waarbij 83\% (AUC) van de leerlingen meer baat hadden van de interventie dan van de wachtlijstcontroleconditie. De NNT van 1,5 wijst op de grote efficiëntie van de interventie.

\section{Buitenlandse interventie: Stress inoculation training}

Deze training is onderzocht in een gerandomiseerde studie onder leerlingen van 48 scholen (Kiselica et al., 1994). Er werd bezien in hoeverre angstklachten zoals gemeten met de State-Trait Anxiety Inventory (STAI; Spielberger, 1983) afnamen. De resultaten zijn weergegeven in tabel 4.6 . 
Tabel 4.6: Effectiviteit van stress inoculation training bij jongeren op klachtenreductie (STAI $\left.{ }^{a}\right)^{b}$.

\begin{tabular}{|c|c|c|c|c|}
\hline & & & $\begin{array}{l}\text { Interventiegroep } \\
\qquad(\mathrm{n}=24)\end{array}$ & $\begin{array}{c}\text { Controlegroep } \\
\qquad(\mathrm{n}=24)\end{array}$ \\
\hline Pre: M (Sd) & & & $45,6(4,8)$ & $45,0(4,2)$ \\
\hline Post: M & & & 40,1 & 44,4 \\
\hline \multirow[t]{2}{*}{ Pre-post: d } & & & 1,1 & 0,1 \\
\hline & & $95 \% \mathrm{BI}$ & & \\
\hline$\Delta(\mathrm{d})$ & 0,99 & $(0,39 \sim 1,59)$ & & \\
\hline AUC & 0,76 & $(0,61 \sim 0,87)$ & & \\
\hline Risicoverschil (RV) & 0,52 & $(0,21 \sim 0,74)$ & & \\
\hline NNT & 1,9 & & & \\
\hline
\end{tabular}

a State-Trait Anxiety Inventory (Spielberger, 1983).

b Kiselica et al., 1994; voor een uitleg van deze tabel zie tekstblok 2.3.

In de interventiegroep is een verbetering te zien van 0,99 standaard eenheden ten opzichte van de attentiecontrolegroep. Dit moet gezien worden als een groot effect. De AUC wijst er op dat 76\% van de leerlingen meer profijt had van de interventie dan van de controleconditie. De NNT van 1,9 attendeert op de efficiëntie van de interventie.

Deze buitenlandse studie geeft heel waarschijnlijk een te rooskleurig beeld van de potentiële effectiviteit in de Nederlandse situatie. De gevonden effecten dienen genuanceerd te worden: na de interventie scoren de leerlingen op de gebruikte vragenlijst gemiddeld nog ruim boven de 34, wat in Nederland gezien wordt als de grens voor klinisch relevante angstklachten. Het is daarmee nog onzeker hoe deze interventie het in de Nederlandse context zou doen. Dat vraagt om nader onderzoek.

\section{Conclusies behaalbare gezondheidswinst van preventie angststoornissen bij jongeren}

Uit de studies die beschreven zijn bij de gezondheidseffecten kan geconcludeerd worden dat er voor jongeren in Nederland één cursus beschikbaar is ter geïndiceerde preventie van een angststoornis die onderzocht is op effectiviteit: de cursus 'Vrienden' (twee varianten: groepscursus en individuele cursus). Deze cursus is middels een Australische gerandomiseerde studie effectief gebleken in het verminderen van de incidentie bij kinderen van 10-13 jaar. Van twee buitenlandse interventies is bekend dat ze effectief zijn op vermindering van angstklachten.

Afgaand op de in Australië gevonden effecten kunnen we de volgende gezondheidswinst in Nederland verwachten: Uitgaande van 126.600 jongeren die jaarlijks een angststoornis ontwikkelen en een bereik van 25\% van deze doelgroep wordt bij 9.495 (ten opzichte van 38.000 bij 100\% bereik) leerlingen een angststoornis vermeden (voor een uitleg van de berekening zie paragraaf 2.5 en tekstblok 1.1). Elk van de onderscheiden angststoornissen heeft zijn eigen wegingsfactor, maar rekening houdend met de prevalentie van de onderscheiden angststoornissen is de gemiddelde wegingsfactor 0,17 . We nemen vervolgens (conservatief) aan dat de gemiddelde ziekteduur in het 
eerste jaar ongeveer acht maanden is (tekstblok 1.1). Bij de genoemde aantallen leerlingen betekent dit een gezondheidswinst van 1.100 DALY's (ten opzichte van 4.300 DALY's bij 100\% bereik; tabel 4.14).

\subsection{Preventieve interventies voor angststoornissen bij volwassenen en ouderen}

In deze paragraaf geven we een samenvatting van de in Nederland beschikbare preventieve interventies voor angststoornissen bij volwassenen en ouderen. In paragraaf 4.4.1 komen de in Nederland beschikbare interventies aan bod. De interventies zijn ingedeeld in universele, selectieve en geïndiceerde preventie (paragraaf 2.3). Aan het eind van deze paragraaf staat een tabel met alle beschikbare interventies ter preventie van angststoornissen bij volwassenen en ouderen (tabel 4.7). Paragraaf 4.4 .2 beschrijft gezondheidseffecten van die interventies die in een gerandomiseerde studie geëvalueerd zijn, inclusief conclusies over de behaalbare gezondheidswinst. Voor een uitgebreide beschrijving van de in Nederland beschikbare interventies ter preventie van angststoornissen bij volwassenen en ouderen verwijzen we naar bijlage 4. Voor een uitleg van de beoordeling op ontwikkelingsfase en wetenschappelijke status verwijzen we naar paragraaf 2.4 .

\subsubsection{In Nederland beschikbare interventies voor preventie van angststoornissen bij volwassenen en ouderen}

De interventies die we hierna beschrijven zijn gericht op volwassenen van 18 jaar en ouder. In Nederland worden weinig interventies aangeboden ter preventie van angststoornissen die zich specifiek richten op ouderen. Er is in dit hoofdstuk daarom geen aparte paragraaf opgenomen over ouderen.

\section{Universele preventie van angststoornissen bij volwassenen en ouderen}

Universele preventie gericht op preventie van angststoornissen bij volwassenen is tot op heden nog weinig systematisch ontwikkeld en bestaat vooral uit voorlichting via brochures, folders en websites. De meeste voorlichtingsactiviteiten zijn echter gericht op mensen met reeds bestaande angstklachten en hun directe omgeving. Dit valt feitelijk onder geïndiceerde preventie (vroegsignalering en vroege interventie) en komt elders aan de orde.

- De campagne 'Kopzorgen’ (Van de Plassche, 2004) richt zich op volwassenen en ouderen met milde angst- en depressiviteitsklachten. Doel van dit project is ondermeer bewustmaking en het bespreekbaar maken van angst- en depressiviteitsklachten. Gestreefd wordt om het taboe rond angst- en depressiviteitsklachten te doorbreken. Het is niet bekend in hoeverre deze campagne geleid heeft tot meer bekendheid onder de doelgroep en tot bewustwording van klachten (Van de Plassche, 2004).

Ontwikkelingsfase: onbekend. Wetenschappelijke status: onbekend. 


\section{Selectieve preventie van angststoornissen bij volwassenen en ouderen}

In Nederland zijn geen selectieve preventieve interventies waarvan het effect op angststoornissen bij volwassenen en ouderen is vastgesteld.

\section{Geïndiceerde preventie van angststoornissen bij volwassenen en ouderen}

De volgende preventieve programma's zijn in Nederland beschikbaar voor volwassenen en ouderen:

- De begeleide internetcursus 'Alles onder controle' (Cuijpers, 2004) is bedoeld voor mensen die last hebben van depressiviteitsklachten (hoofdstuk 3, paragraaf 3.4), maar ook voor mensen met angsten, spanningen en werkstress. Het doel van de interventie is om in ongeveer vier weken een betere greep op het eigen leven te krijgen door problemen die verantwoordelijk zijn voor de klachten gericht en planmatig aan te pakken. De interventie is in een gerandomiseerde studie geëvalueerd (paragraaf 4.4.2).

Ontwikkelingsfase: I. Wetenschappelijke status: ${ }^{* *}$.

- De zelfhulpcursus in een groep met minimale begeleiding 'Hallo, hier ben ik' (Van der Molen, 1985) richt zich op verlegen mensen en mensen met beginnende klachten van sociale fobie. De cursus heeft als doel zelf, maar in een groep van lotgenoten, aan de slag te gaan met verlegenheid. De voorloper van deze interventie (een groepscursus) is in een gerandomiseerde studie geëvalueerd (paragraaf 4.4.2). De gevonden effecten gelden echter niet automatisch voor de huidige zelfhulpversie. Ontwikkelingsfase: G. Wetenschappelijke status: *.

- 'Zelf aan de slag met angstige gevoelens' (Van Mierlo et al., 2004) is een schriftelijke zelfhulpcursus, gebaseerd op gedragstherapeutische principes. Doelgroep: mensen met lichte tot matige angstklachten, in het bijzonder klachten rondom paniek, sociale fobie en gegeneraliseerde angst. Doel: voorkomen van angststoornis, afname van angstklachten, leren van vaardigheden om de angstklachten te hanteren, voorkomen van terugval.

Ontwikkelingsfase: G. Wetenschappelijke status: *.

- De groepscursussen 'Angst in de hand' (Van Mierlo et al., 2005) en 'Angst de Baas' (Timmerman, 2004) zijn sterk aan elkaar verwant. Daarom bespreken we ze hier samen. Beide cursussen zijn gebaseerd op cognitieve gedragstherapie. Van 'Angst in de hand' bestaat een aparte versie voor studenten, en voor ouderen is er de cursus 'Angst de Baas 55+' (Akkermans et al., 2003). Doelgroep: mensen van 18-55 jaar (apart voor 55+) met milde tot matige klachten rondom paniek, sociale fobie en gegeneraliseerde angst. Het doel van de cursussen is behalve preventie van een angststoornis ook het hanteren van angstklachten en het verhogen van welbevinden.

Ontwikkelingsfase G. Wetenschappelijke status volwassenen- en ouderenvariant 'Angst de Baas 55+': *.

- 'Geen Paniek!' (Meulenbeek et al., 2005) is een groepscursus voor mensen van 18-65 jaar met milde tot matige paniekklachten met of zonder agorafobische klachten. De cursus is gebaseerd op cognitieve gedragstherapie. Doel: reductie van paniekklachten, voorkomen dat de klachten of de gevolgen hiervan verergeren en dat personen die van een paniekstoornis hersteld zijn een terugval krijgen. Momenteel vindt een 
Tabel 4.7: Overzicht van in Nederland beschikbare interventies ter preventie van angststoornissen bij volwassenen en ouderen.

\begin{tabular}{|c|c|c|c|c|c|}
\hline & $\begin{array}{l}\text { Soort } \\
\text { Inter- } \\
\text { ventie }^{a}\end{array}$ & $\begin{array}{l}\text { Ontwik- } \\
\text { kelings- } \\
\text { fase }^{\text {b }}\end{array}$ & $\begin{array}{l}\text { Wetensch. } \\
\text { status }^{c}\end{array}$ & $\begin{array}{l}\text { Uit- } \\
\text { komst- } \\
\text { maat d }\end{array}$ & Doelgroep \\
\hline \multicolumn{6}{|l|}{ Universeel } \\
\hline Kopzorgen & $\begin{array}{l}\text { Cam- } \\
\text { pagne }\end{array}$ & $\begin{array}{l}\text { onbe- } \\
\text { kend }\end{array}$ & onbekend & - & volwassenen en ouderen \\
\hline \multicolumn{6}{|l|}{ Selectief } \\
\hline \multicolumn{6}{|l|}{-} \\
\hline \multicolumn{6}{|l|}{ Geïndiceerd } \\
\hline $\begin{array}{l}\text { Alles onder con- } \\
\text { trole }\end{array}$ & Internet & I & ** & $\mathrm{K}$ & $\begin{array}{l}\text { volwassenen en ouderen met } \\
\text { klachten van depressiviteit, } \\
\text { angst, spanning, en/of } \\
\text { werkstress }\end{array}$ \\
\hline Hallo, hier ben ik & $\begin{array}{l}\text { Zelfhulp } \\
\text { (bege- } \\
\text { leid) }\end{array}$ & G & * & $\mathrm{K}$ & $\begin{array}{l}\text { verlegen mensen, mensen met } \\
\text { beginnende klachten sociale } \\
\text { fobie }\end{array}$ \\
\hline $\begin{array}{l}\text { Zelf aan de slag } \\
\text { met angstige } \\
\text { gevoelens }\end{array}$ & Groep & G & * & $\mathrm{K}$ & $\begin{array}{l}\text { mensen met paniek-, sociaal- } \\
\text { fobische en/of gegeneraliseerde } \\
\text { angstklachten }\end{array}$ \\
\hline $\begin{array}{l}\text { Angst in de hand } \\
(\text { volw } / 55+) /\end{array}$ & Groep & G & * & $\mathrm{K}$ & $\begin{array}{l}\text { jongvolwassenen, volwassenen } \\
\text { en ouderen (elk aparte versies) }\end{array}$ \\
\hline Angst de baas & & & & & $\begin{array}{l}\text { met paniekklachten, sociale } \\
\text { fobie en gegeneraliseerde angst }\end{array}$ \\
\hline Stap voor stap & Groep & G & * & $\mathrm{K}$ & $\begin{array}{l}\text { Turkse en Marokkaanse volwas- } \\
\text { senen en ouderen }(50+) \text { met } \\
\text { angstklachten of lichte angst- } \\
\text { stoornis }\end{array}$ \\
\hline Geen paniek & Groep & G & * & $\mathrm{R}$ & $\begin{array}{l}\text { volwassenen } 18-65 \text { jaar met } \\
\text { paniekklachten }\end{array}$ \\
\hline $\begin{array}{l}\text { Leren omgaan } \\
\text { met verlegenheid }\end{array}$ & Groep & I & * & $\mathrm{K}$ & $\begin{array}{l}\text { volwassenen met sociaal- } \\
\text { fobische klachten }\end{array}$ \\
\hline Geen paniek & Zelfhulp & I & onbekend & - & $\begin{array}{l}\text { volwassenen 18-65 jaar met } \\
\text { paniekklachten }\end{array}$ \\
\hline Angst de baas & Zelfhulp & I & onbekend & - & $\begin{array}{l}\text { volwassenen en ouderen (elk } \\
\text { aparte versies) met paniek- } \\
\text { klachten, sociale fobie en } \\
\text { gegeneraliseerde angst }\end{array}$ \\
\hline $\begin{array}{l}\text { Buitenland: Eén- } \\
\text { daagse workshop } \\
\text { paniekklachten }\end{array}$ & Groep & B & *** & I & mensen met paniekklachten \\
\hline $\begin{array}{l}\text { Buitenland: } \\
\text { Psycho-educatieve } \\
\text { instructie } \\
\text { bij EHBO }\end{array}$ & $\begin{array}{l}\text { Indivi- } \\
\text { dueel }\end{array}$ & B & *** & $\mathrm{K}$ & $\begin{array}{l}\text { mensen die op de eerstehulp- } \\
\text { afdeling van een ziekenhuis- } \\
\text { komen met paniekklachten }\end{array}$ \\
\hline $\begin{array}{l}\text { Buitenland: } \\
\text { Cognitieve inter- } \\
\text { netinterventie }\end{array}$ & Internet & B & ** & $\mathrm{K}$ & mensen met paniekklachten \\
\hline
\end{tabular}

\footnotetext{
a Soort interventie: Groep = groepscursus, Internet = internetcursus, Zelfhulp = schriftelijke zelfhulpcursus (paragraaf 2.3).

b Ontwikkelingsfase: I = innovatief, G = gestandaardiseerd ('good practice'), B = buitenlands (paragraaf 2.3).

c Wetenschappelijke status: ${ }^{*}=$ gepubliceerde mening van deskundigen, of mening van werkgroepleden, ** = gebaseerd op één gerandomiseerde trial of meerdere onderzoeken zonder controlegroep (paragraaf 2.4).

${ }^{\mathrm{d}}$ Uitkomstmaat: $\mathrm{I}$ = effect op incidentie, $\mathrm{R}=$ effect op risicostatus, $\mathrm{K}=$ effect op klachten (paragraaf 2.4).
} 
gerandomiseerde studie annex kosten-effectiveitsstudie plaats. De resultaten daarvan worden verwacht in 2007 (voor meer informatie zie www.cursusgeenpaniek. nl). Ook is er een internetversie van 'Geen Paniek' in ontwikkeling. Ontwikkelingsfase: G; wetenschappelijk status: *.

- De groepscursus ‘Stap voor Stap’ (De Vries \& Smits, 2005) is vergelijkbaar met 'Angst in de hand' en 'Angst de baas', maar is bestemd voor Turken en Marokkanen van 50 jaar en ouder.

Ontwikkelingsfase: G. Wetenschappelijke status: *.

- De groepscursus 'Leren omgaan met verlegenheid' (Rademakers \& Groen, 2003) richt zich op mensen van 18 jaar en ouder die last hebben van sociaal fobische klachten. Het doel is om de deelnemers handvatten te geven om de klachten te hanteren en te voorkomen dat deze verergeren. De cursus is gebaseerd op gedragstherapeutische technieken, sociale vaardigheden en probleemoplossende technieken en werd alleen als pilot uitgevoerd. Een recente versie van deze cursus is in ontwikkeling 'Met Lef: Zelfverzekerd in contact met anderen'.

Ontwikkelingsfase: I. Wetenschappelijke status: *.

De groepscursussen als 'Geen Paniek' en 'Angst de baas' worden soms aangeboden als begeleide zelfhulpcursus.

De volgende cursussen worden (nog) niet in Nederland aangeboden, maar laten in het buitenland interessante effecten zien, zoals wordt beschreven in paragraaf 4.4.2.

- De ‘Eéndaagse workshop voor paniekklachten’ is gebaseerd op cognitief-gedragstherapeutische principes, voor mensen die minstens één paniekaanval hebben gehad, zonder dat zij voldeden aan de criteria voor een paniekstoornis (Gardenswartz \& Craske, 2001; zie ook WHO, 2004).

Ontwikkelingsfase: B. Wetenschappelijke status: **.

- De 'Psycho-educatieve instructie op eerste hulppost' (Swinson et al., 1992) is een interventie waarbij psycho-educatieve instructies worden aangeboden aan mensen die met paniekklachten en agorafobische klachten op een eerste hulppost van een ziekenhuis verschijnen. In gerandomiseerd onderzoek nam het aantal paniekaanvallen af. Er werd geen effect op de agorafobische klachten gevonden (Swinson et al., 1992).

Ontwikkelingsfase: B. Wetenschappelijke status **.

- De cursus 'Cognitieve internetinterventie’ (Kenardy et al., 2003) richt zich op mensen met beginnende paniekklachten en bestaat uit zes gestructureerde sessies die in vijf tot zeven dagen doorlopen kunnen worden. In Nederland is zo'n interventie nog niet beschikbaar, maar al wel in voorbereiding. Gerandomiseerd onderzoek liet een afname van angstklachten zien (Kenardy et al., 2003).

Ontwikkelingsfase: B. Wetenschappelijke status **.

\subsubsection{Gezondheidseffecten van preventie van angststoornissen bij volwassenen en ouderen}

Van de bovenbeschreven interventies die in Nederland beschikbaar zijn voor preventie van angststoornissen bij volwassenen en ouderen zijn er twee onderzocht in een 
Nederlandse gerandomiseerde studie: de begeleide zelfhulpcursus 'Hallo, hier ben ik' (Van der Molen, 1985) en de internetcursus 'Alles onder controle’ (Cuijpers, 2004). Ook de drie genoemde buitenlandse cursussen zijn in gerandomiseerd onderzoek geëvalueerd: de ééndaagse workshop voor paniekklachten, de psycho-educatieve instructies op eerstehulppost en de cognitieve internetinterventie. We bespreken deze studies om iets te kunnen zeggen over de haalbare gezondheidswinst.

\section{Begeleide zelfhulpcursus 'Hallo, hier ben ik'}

In 1985 promoveerde Van der Molen op een effectevaluatie van de cursus 'Aan verlegenheid valt iets te doen'. Later heeft Van Wandelen deze cursus bewerkt tot een zelfhulpboek 'Hallo, hier ben ik'. In het effectonderzoek van Van der Molen werd de cursus vergeleken met een eclectische alternatieve interventie van cognitief-gedragstherapeutische signatuur. De effectmaat was samengesteld en bestaat uit de gemiddelde gestandaardiseerde effectgrootte over meerder dimensies (beleving, cognities, gedragingen, vermijding) van sociale angst. Direct aan het einde van de interventie werd een gemiddelde gestandaardiseerde effectgrootte, d, van 1,55 gevonden in de interventiegroep tegen 0,98 in de alternatieve interventie. Drie maanden later werden op de follow-up meting effecten gevonden van respectievelijk $d=1,57$ en $d=0,85$. Hiermee rekenen we verder (tabel 4.8).

Tabel 4.8: Effectiviteit van de zelfhulpcursus 'Hallo, hier ben ik' op sociaal-fobische klachten en vermijding ${ }^{a}$.

\begin{tabular}{lccc}
\hline & & $\begin{array}{c}\text { Interventiegroep } \\
(\mathrm{n}=49)\end{array}$ & $\begin{array}{c}\text { Controlegroep } \\
(\mathrm{n}=38)\end{array}$ \\
\hline Pre-post: $\mathrm{d}$ & & 1,6 & 0,9 \\
& & & \\
$\Delta(\mathrm{d})$ & 0,72 & $95 \% \mathrm{BI}$ & \\
AUC & 0,69 & $(0,28 \sim 1,16)$ & \\
Risicoverschil (RV) & 0,38 & $(0,16 \sim 0,59)$ & \\
NNT & 2,6 & & \\
\hline
\end{tabular}

${ }^{a}$ Van der Molen (1985); voor een uitleg van deze tabel zie tekstblok 2.3.

Uit tabel 4.8 blijkt dat de cursus superieur is aan de alternatieve interventie. De _(d) is middelgroot en statistisch significant. De lage NNT wijst op grote efficiëntie. Het kan zijn dat de zelfhulpversie minder grote effecten heeft, dus hier houden we een slag om de arm.

\section{Begeleide internetcursus 'Alles onder controle'}

Gerandomiseerd onderzoek (Van Straten et al., in voorbereiding) van de begeleide internetcursus 'Alles onder controle' (Cuijpers, 2004) laat zien dat de interventie gunstige effecten heeft op depressie, angstklachten, werkstress en burnout. Hier bespreken we alleen de effecten op angstklachten. De betreffende uitkomstvariabele is de SCL-A, een instrument waarmee (veranderingen in) angstklachten geëvalueerd kunnen worden (Derogatis, 1977). De resultaten zijn weergegeven in tabel 4.9. 
Tabel 4.9: Effectiviteit van de internetcursus 'Alles onder controle' op angstklachten (SCL-A $\left.{ }^{a}\right)^{b}$.

\begin{tabular}{|c|c|c|c|c|}
\hline & & & $\begin{array}{l}\text { Interventiegroep } \\
\quad(n=107)\end{array}$ & $\begin{array}{c}\text { Controlegroep } \\
(n=106)\end{array}$ \\
\hline Pre: M (Sd) & & & $24,1(7,4)$ & $23,7(7,2)$ \\
\hline Post: M & & & 19,4 & 22,8 \\
\hline \multirow[t]{2}{*}{ Pre-post: d } & & & 0,64 & 0,13 \\
\hline & & $95 \% \mathrm{BI}$ & & \\
\hline$\Delta(\mathrm{d})$ & 0,51 & $(0,24 \sim 0,78)$ & & \\
\hline AUC & 0,64 & $(0,57 \sim 0,71)$ & & \\
\hline Risicoverschil (RV) & 0,28 & $(0,13 \sim 0,42)$ & & \\
\hline NNT & 3,6 & & & \\
\hline
\end{tabular}

a Symptom Check List (Derogatis, 1977).

b Cuijpers, 2004; voor een uitleg van deze tabel zie tekstblok 2.3.

Tabel 4.10: Effectiviteit van de ééndaagse workshop op paniekklachten bij volwassenen (CIDI $\left.{ }^{a}\right)^{b}$.

\begin{tabular}{|c|c|c|c|c|}
\hline & & & $\begin{array}{l}\text { Interventiegroep } \\
\qquad(\mathrm{n}=66)\end{array}$ & $\begin{array}{c}\text { Controlegroep } \\
(n=67)\end{array}$ \\
\hline Kreeg stoornis & & & 1 & 9 \\
\hline Bleef stoornisvrij & & & 65 & 58 \\
\hline \multirow[t]{2}{*}{ Risico op de stoornis } & & & 0,02 & 0,13 \\
\hline & & $95 \% \mathrm{BI}$ & & \\
\hline Risicoverschil (RV) & 0,12 & $(-0,03 \sim 0,21)$ & & \\
\hline Relatief risico (RR) & 0,11 & $(0,01 \sim 0,87)$ & & \\
\hline NNT & 8,4 & & & \\
\hline
\end{tabular}

De data werden geanalyseerd in overeenstemming met het intention-to-treat principe. De interventiegroep biedt meerwaarde ten opzichte van de controle: $\Delta(\mathrm{d})=0,51$. Dat kan als een middelgroot effect gezien worden. De AUC geeft aan in hoeverre de interventie een grotere kans geeft op een goede uitkomst dan de controle conditie. Wanneer AUC groter is dan 0,50 is die kans in het voordeel van de interventie. De tabel laat zien dat dit het geval is: $A U C=0,64$, en ook de ondergrens van AUC $(0,57)$ ligt boven de waarde van 0,50 . Het risicoverschil, is gelijk aan 0,28 . Dit vertaalt zich in een numbers-needed-to-be-treated, NNT, van 3,6. Dat wijst op een grote efficiëntie van deze interventie wat betreft het reduceren van depressiviteitsklachten: slechts $4(3,6)$ personen dienen ontvanger te zijn van de interventie om bij één van hen de angstklachten succesvol terug te dringen.

\section{Buitenlandse interventie: Eéndaagse workshop voor paniekklachten}

De effectiviteit van deze cursus werd onderzocht door Gardenswartz \& Craske (2001; zie ook WHO, 2004). In het effectonderzoek werden deelnemers vergeleken met een 
Tabel 4.11: Effectiviteit van psycho-educatie bij de EHBO op het aantal paniekaanvallen ${ }^{a b}$.

\begin{tabular}{lccc}
\hline & & $\begin{array}{c}\text { Interventiegroep } \\
(\mathrm{n}=17)\end{array}$ & $\begin{array}{c}\text { Controlegroep } \\
(\mathrm{n}=16)\end{array}$ \\
\hline Pre: $\mathrm{M}$ (Sd) & & $2,5(3,3)$ & $2,5(3,5)$ \\
Post: $\mathrm{M}$ & & 0,8 & 3,4 \\
Pre-post: d & & 0,53 & $-0,25$ \\
& & & \\
& & & \\
(d) & & $95 \% \mathrm{BI}$ & \\
AUC & 0,78 & $(0,01 \sim 1,49)$ & \\
Risicoverschil (RV) & 0,71 & $(0,50 \sim 0,85)$ & \\
NNT & 0,42 & $(0,01 \sim 0,71)$ & \\
\hline
\end{tabular}

a Paniekaanvallen gemeten o.b.v. consensus-afspraak patiënt-therapeut (Ballenger et al., 1988).

b Swinson et al. (1992); voor een uitleg van deze tabel zie tekstblok 2.3.

wachtlijstgroep. De aan- of afwezigheid van een diagnose paniekstoornis werd vastgesteld met behulp van de Comprehensive International Diagnostic Interview (CIDI; WHO, 1997). In de zes maanden na de workshop ontwikkelde $13 \%$ uit de wachtlijstcontrolegroep een paniekstoornis, in vergelijking tot $2 \%$ uit de experimentele groep. Deze verschillen waren significant (tabel 4.10).

Er is dus sprake van een statistisch significant $(\mathrm{p}<0,05)$ en klinisch relevant $(R R=0,11)$ effect dat bovendien op een relatief efficiënte wijze werd verkregen $(\mathrm{NNT}=8,4)$, vooral in beschouwing nemend dat de interventie bestaat uit een workshop van één dag. Voor deze interventie is in bijlage 6 een economische doorrekening gemaakt.

\section{Buitenlandse interventie: Psycho-educatieve instructie op eerste hulppost}

Swinson et al. (1992) deden gerandomiseerd onderzoek naar een psycho-educatieve interventie op een eerste hulppost van een ziekenhuis. Bij mensen die met paniekklachten en agorafobische klachten op de eerste hulp verschenen, werden psychoeducatieve instructies aangeboden. In de controleconditie werden patiënten alleen gerustgesteld. Er werd naar twee, hier relevante, uitkomsten gekeken: reductie in paniekaanvallen en agorafobische klachten. De uitkomsten staan in twee tabellen: één voor het effect op het aantal paniekaanvallen (tabel 4.11), de ander voor het effect op agorafobische klachten (tabel 4.12).

De interventie heeft statistisch significante en klinisch substantiële effecten op het aantal paniekaanvallen. Het gemiddeld aantal paniekaanvallen per week kan verminderen wanneer mensen angstopwekkende situaties vermijden. Het is daarom van belang om ook te bezien wat het effect van de interventie is op agorafobische klachten (vermijden van angstopwekkende situaties; tabel 4.12). 
Tabel 4.12: Effectiviteit van psycho-educatie bij de EHBO op agorafobische klachten (Fear Questionnaire $\left.{ }^{a}\right)^{b}$.

\begin{tabular}{lccc}
\hline & & $\begin{array}{c}\text { Interventiegroep } \\
(\mathrm{n}=17)\end{array}$ & $\begin{array}{c}\text { Controlegroep } \\
(\mathrm{n}=16)\end{array}$ \\
\hline Pre: $\mathrm{M}$ (Sd) & & $4,4(6,3)$ & $4,1(5,7)$ \\
Post: $\mathrm{M}$ & & 2,5 & 5,5 \\
Pre-post: d & & 1,14 & 0,15 \\
& & & \\
$\Delta(\mathrm{d})$ & & $95 \% \mathrm{BI}$ & \\
AUC & 0,58 & $(-0,12 \sim 1,27)$ & \\
Risicoverschil (RV) & 0,66 & $(0,47 \sim 0,82)$ & \\
NNT & 0,32 & $(-0,63 \sim 0,07)$ & \\
\hline
\end{tabular}

${ }^{\text {a }}$ Marks \& Mathews (1979).

b Swinson et al., 1992; voor een uitleg van deze tabel zie tekstblok 2.3.

Gezien de betrouwbaarheidsintervallen zijn de resultaten niet significant. We besteden er toch aandacht aan. Ten eerste is de steekproef bijzonder klein, zodat statistische significantie om die reden al nauwelijks te verwachten is, en ten tweede is een gestandaardiseerde effectgrootte van $d=0,58$ vanuit klinisch oogpunt te beschouwen als een middelgroot effect. Ook wijzen het risicoverschil $(\mathrm{RV}=0,32)$ en de corresponderende NNT van 1,9 op een zowel effectieve als efficiënte interventie.

Daarnaast is de interventie eenvoudig te implementeren (patiënten op de eerste hulppost gericht voorlichten in plaats van kalmeren). Verder ligt het in de verwachting dat aan deze interventie economische voordelen verbonden zijn, omdat bekend is dat mensen met paniekklachten vaak ten onrechte gebruik maken van ambulances en eerste hulp afdelingen van ziekenhuizen (Yingling et al., 1993). Dyckman et al. (1999) rapporteren vergelijkbare effecten, en spreken van therapeutisch en economisch belangrijke resultaten.

\section{Buitenlandse interventie: Internet-delivered prevention for anxiety disorders}

Kenardy et al. (2003) beschrijven een gerandomiseerde studie waarin de cognitieve internetinterventie met een wachtlijstcontrolegroep vergeleken wordt. Na afloop van de interventie werden de uitkomsten ervan geëvalueerd met de Anxiety Sensitivity Index (ASI; Peterson \& Reiss, 1992) als primaire uitkomstmaat. Scores op de ASI hoger dan 30,5 wijzen op klinisch relevante paniekklachten. De resultaten laten middelgrote effecten zien die in een 1-zijdige toets significant zijn (tabel 4.13).

\section{Conclusies behaalbare gezondheidswinst van preventie angststoornissen bij volwassenen en ouderen}

Van slechts weinig interventies is de effectiviteit onderzocht. Op dit moment zijn er slechts twee geïndiceerde interventies die degelijk geëvalueerd zijn en die tot een aantoonbare klachtenreductie leiden: de zelfhulpcursus 'Hallo, hier ben ik' en de groepscursus 'Alles onder controle’. Omdat er geen effect op incidentie is gemeten, is 
Tabel 4.13: Effectiviteit van cognitieve internet preventie bij paniekklachten $\left(\text { ASI }^{a}\right)^{b}$.

\begin{tabular}{lccc}
\hline & & $\begin{array}{c}\text { Interventiegroep } \\
(\mathrm{n}=43)\end{array}$ & $\begin{array}{c}\text { Controlegroep } \\
(\mathrm{n}=40)\end{array}$ \\
\hline Pre: $\mathrm{M}$ (Sd) & & $30,6(5,3)$ & $30,4(5,5)$ \\
Post: M & & 21,9 & 24,7 \\
Pre-post: d & & 0,97 & 0,61 \\
& & & \\
$\Delta(\mathrm{d})$ & & & \\
AUC & 0,36 & $(-0,07 \sim 0,71)$ & \\
Risicoverschil (RV) & 0,60 & $(0,48 \sim 0,71)$ & \\
NNT & 0,20 & $(-0,04 \sim 0,42)$ & \\
\hline P & 4,9 & & \\
\end{tabular}

$\mathrm{p}=0,04$ (eenzijdig)

a Anxiety Sensitivity Index (Peterson \& Reiss, 1992).

b Kenardy et al., 2003; voor een uitleg van deze tabel zie tekstblok 2.3 .

het echter niet mogelijk om de behaalbare gezondheidswinst van deze interventies te berekenen. Er loopt in Nederland momenteel een gerandomiseerd kosteneffectiviteitsonderzoek naar de groepscursus ‘Geen Paniek'. Een internetvariant van deze cursus is in voorbereiding.

\subsection{Samenvatting en conclusies preventie angststoornissen}

\section{Omvang, ernst en gevolgen}

De omvang van angststoornissen zijn enorm: het afgelopen jaar leden ongeveer 1,7 miljoen mensen in Nederland eraan. Ook de ziektelast van de geselecteerde angststoornissen is groot: deze bedraagt minimaal 227 duizend DALY's. Het zorggebruik voor angststoornissen is, in verhouding tot de enorme omvang van het probleem, zeer laag. De zorgkosten zijn in totaal zo'n 275 miljoen euro. Daarnaast kost het ziekteverzuim als gevolg van angststoornissen bijna 4 miljard euro. In 2002 waren ongeveer 16 duizend mensen als gevolg van de geselecteerde angststoornissen arbeidsongeschikt. Het aantal nieuwe gevallen van angststoornissen bedraagt jaarlijks naar schatting ruim 463 duizend mensen; zij vertegenwoordigen ongeveer 53 duizend DALY's. De zorgkosten voor nieuwe gevallen van angststoornissen bij volwassenen bedragen jaarlijks zo'n 87 miljoen euro; daarnaast genereren ze bijna 999 miljoen euro aan kosten als gevolg van ziekteverzuim. Gezien de grote omvang van angststoornissen, de hoge jaarlijkse instroom van nieuwe gevallen en de hoge kosten ten gevolge van ziekteverzuim is preventie van angststoornissen belangrijk.

\section{Achterstand in preventie angststoornissen}

Er worden belangrijke inspanningen geleverd op het gebied van universele, selectieve en geïndiceerde preventie. Echter, in vergelijking tot depressie moeten we een achterstand constateren op het gebied van de preventie van angststoornissen. Het be- 
staande aanbod is relatief beperkt, bestrijkt niet alle relevante angststoornissen, is niet voldoende onderzocht, en voor volwassenen en ouderen ontbreekt een aanbod voor selectieve preventie van angststoornissen. Zelfs vanuit internationaal perspectief bezien is er nauwelijks onderzoek verricht naar de effecten van bestaande interventies (Cuijpers \& Bohlmeijer, 2001; Hudson et al., 2004; Story et al., 2004). Deze achterstand is opmerkelijk en vraagt zeker om aandacht, omdat de prevalentie van angststoornissen groter is dan die van depressie, en de ziektelast van bepaalde angststoornissen zoals paniekstoornis die van depressie op zijn minst evenaart.

Wel is de laatste jaren sprake van een groeiend preventief aanbod voor volwassenen met angstklachten. Het Landelijk Platform Preventie van Angstklachten speelt een belangrijke rol om inspanningen op dit gebied te inventariseren, te bundelen en richting te geven.

Tabel 4.14 geeft een overzicht van die interventies waarvan de behaalbare gezondheidswinst op bevolkingsniveau is berekend. Daarbij zijn we uitgegaan van een realistisch te behalen bereik van 25\%. Deze wordt vergeleken met een gezondheidswinst die zou ontstaan bij een theoretisch maximaal bereik van $100 \%$.

\section{Aanbevelingen voor preventie van angststoornissen bij jongeren}

Voor jongeren is er slechts één effectieve geïndiceerde preventieve interventie beschikbaar: de cursus 'Vrienden' (groepsvariant en individuele variant). Deze cursus is middels een Australische gerandomiseerde studie effectief gebleken in het verminderen van de incidentie bij kinderen van 10 tot en met 13 jaar. Hoewel de effecten van de interventie bij jongeren minder vaak is onderzocht, zijn er aanwijzingen dat de interventie ook effectief kan zijn in klachtenreductie bij deze doelgroep. De cursus 'Vrienden' lijkt in aanmerking te komen voor implementatiestudies; tegelijkertijd is een betere wetenschappelijke onderbouwing voor de effectiviteit bij de doelgroep jongeren (vanaf 13 jaar) noodzakelijk.

Buitenlands onderzoek laat zien dat er interessante interventies zijn die nog niet in Nederland worden toegepast, maar wel een goede aanvulling kunnen vormen op het Nederlandse aanbod. Dit zijn met name de ‘Angstmanagmenttrainingen' voor jongeren.

Er is nog nauwelijks een interventieaanbod voor selectieve en universele preventie van angststoornissen. De beschikbare cursus 'Vrienden' is al gestandaardiseerd en zou verder geëvalueerd kunnen worden als selectieve interventie. Hetzelfde geldt voor de beschikbare groepscursus 'Plezier op school', hoewel deze interventie zich nog in een innovatieve ontwikkelingsfase bevindt.

\section{Aanbevelingen voor preventie van angststoornissen bij volwassenen en ouderen}

Voor volwassenen en ouderen is er slechts één geïndiceerde interventies die degelijk geëvalueerd is en die tot een aantoonbare klachtenreductie leidt: de begeleide internetcursus ‘Alles onder controle'. Wat de effectiviteit betreft is deze cursus geschikt voor 
Tabel 4.14: Gezondheidswinst van preventie van angststoornissen in te voorkomen nieuwe gevallen van angststoornissen en te voorkomen DALY's.

\begin{tabular}{|c|c|c|c|c|c|c|c|}
\hline \multirow[t]{3}{*}{ Interventie $^{\mathrm{a}}$} & \multirow{3}{*}{\multicolumn{2}{|c|}{$\begin{array}{l}\text { Uitkomstmaat } \\
\text { b en wetensch. } \\
\text { status }^{\mathrm{c}}\end{array}$}} & \multirow{3}{*}{$\begin{array}{l}\text { Risico } \\
\text { verschil } \\
\text { d }\end{array}$} & \multicolumn{4}{|c|}{$\begin{array}{l}\text { Te behalen gezondheidswinst bij } 25 \% \\
\text { bereik en } 100 \% \text { bereik }\end{array}$} \\
\hline & & & & \multicolumn{2}{|c|}{$\begin{array}{l}\text { Te voorkomen } \\
\text { nieuwe gevallen e }\end{array}$} & \multicolumn{2}{|c|}{$\begin{array}{l}\text { Te voorkomen } \\
\text { DALY's }{ }^{f}\end{array}$} \\
\hline & & & & $25 \%$ & $100 \%$ & $25 \%$ & $100 \%$ \\
\hline \multicolumn{8}{|l|}{ Jongeren } \\
\hline Vrienden (GC) & I & * & 0,30 & 9.500 & 38.000 & 1.100 & 4.300 \\
\hline $\begin{array}{l}\text { Buitenlandse interventies } \\
\text { Angstmanagement (GC) } \\
\text { Stress inoculation (GC) }\end{array}$ & $\begin{array}{l}\mathrm{K} \\
\mathrm{K}\end{array}$ & * & $\begin{array}{l}0,66 \\
0,52\end{array}$ & - & - & - & - \\
\hline \multicolumn{8}{|l|}{ Volwassenen/ouderen } \\
\hline $\begin{array}{l}\text { Hallo, hier ben ik (ZH) } \\
\text { Alles onder controle (IC) }\end{array}$ & $\begin{array}{l}\mathrm{K} \\
\mathrm{K}\end{array}$ & *** & $\begin{array}{l}0,38 \\
0,12\end{array}$ & - & - & - & - \\
\hline $\begin{array}{l}\text { Buitenlandse interventies } \\
\text { 1-dagworkshop paniek } \\
\text { (GC) }\end{array}$ & I & *** & 0,12 & 2.400 & 9.600 & 350 & 1.350 \\
\hline Educatie op EHBO (indiv.) & K & ** & 0,42 & - & - & - & - \\
\hline Internet voor paniek (IC) & K & *** & 0,20 & - & - & - & - \\
\hline $\begin{array}{l}\text { a Soort interventie: GC = groe } \\
\text { interventie. } \\
\text { b }{ }^{\text {b }} \text { itkomstmaat: I = incidentie } \\
\text { c Wetenschappelijke status: } \\
{ }^{* *}=\text { gebaseerd op één geran } \\
\text { 2.4). } \\
\text { d Risicoverschil: het verschil in } \\
\text { (tekstblok 2.3). } \\
\text { e Berekening: incidentie * ber } \\
\text { f Berekening: incidentie * ber } \\
\text { 1.1). Wegingsfactor }=0,17 ; z\end{array}$ & $\begin{array}{l}\text { cur } \\
\mathrm{K}= \\
\text { gep } \\
\text { om }\end{array}$ & $\begin{array}{l}=\text { intern } \\
\text { enreduct } \\
\text { erde mei } \\
\text { trial of } \mathrm{I} \\
\text { en angsts } \\
\text { erschil ( } p \\
\text { erschil }{ }^{*} \text {. } \\
8 \text { mnd. }\end{array}$ & $\begin{array}{l}\text { tcursus, } \mathrm{ZH} \\
\text { e, } \mathrm{R}=\text { verd } \\
\text { ing van de } \\
\text { leerdere on } \\
\text { oornis tuss } \\
\text { ragraaf } 2.5 \\
\text { ekteduur }\end{array}$ & $\begin{array}{l}=\text { zelfhu } \\
\text { zijnen ris } \\
\text { kundiges } \\
\text { lerzoeke } \\
\text { n de int } \\
\text { wegings }\end{array}$ & $\begin{array}{l}\text { nterventie, } \\
\text { status (parc } \\
\text { f mening v } \\
\text { onder cont } \\
\text { entiegroep } \\
\text { or (paragra }\end{array}$ & $\begin{array}{l}\text { indiv. }=\mathrm{i} \\
\text { graaf } 2.4 \\
\text { n werkg } \\
\text { olegroep } \\
\text { en de con } \\
\text { af } 2.5 \text { en }\end{array}$ & $\begin{array}{l}\text { ividuele } \\
\text { pleden, } \\
\text { aragraaf } \\
\text { legroep } \\
\text { stblok }\end{array}$ \\
\hline
\end{tabular}

implementatie-onderzoek. Bovendien is deze cursus kortdurend (ongeveer vier weken) en wordt via het internet aangeboden. De interventie is echter nog niet gestandaardiseerd. Het verdient daarom aanbeveling om deze cursus eerst te standaardiseren voordat implementatie-onderzoek kan plaatsvinden.

Van de meeste interventies die al in een gestandaardiseerde vorm worden aangeboden moet de effectiviteit nog aangetoond worden. Dit geldt voor de interventies die gericht op het reduceren van angstklachten in het algemeen, dus zowel gegeneraliseerde angstklachten, paniekklachten als sociaal-fobische klachten. Daarbij gaat het om de groepscursussen 'Angst in de hand' en 'Angst de baas' (versie volwassenen), de groepscursus 'Zelf aan de slag met angstige gevoelens' voor volwassenen en ouderen, de groepscursus voor Turkse en Marokkaanse volwassenen en ouderen 'Stap voor stap', en de zelfhulpcursus 'Geen Paniek'. Laatstgenoemde interventie is kansrijk, ten eerste omdat deze cursus ook kosteneffectief lijkt te zijn en ten tweede omdat er ook een internetversie in ontwikkeling is. 
Verder zijn specifieke interventies voor mensen met sociaalfobische klachten dun gezaaid. In dat opzicht interessante interventie voor volwassenen zijn de gestandaardiseerde (gedeeltelijke) zelfhulpcursus 'Hallo, hier ben ik' en de innovatieve groepscursus 'Leren omgaan met verlegenheid'. Van de laatste is een nieuwe versie in ontwikkeling: 'Met Lef: zelfverzekerd in contact met anderen'. Beide interventies zijn nog niet voldoende onderzocht op effectiviteit; effectonderzoek naar deze interventies is dus gewenst. Bovendien verdient het aanbeveling om de groepscursus 'Leren omgaan met verlegenheid'/'Met Lef' te standaardiseren.

Specifiek voor mensen met paniekklachten zijn er enkele interessante interventies die nog niet in Nederland worden aangeboden, maar al wel in het buitenland hun waarde hebben bewezen. Dit zijn de ‘Eéndaagse workshop voor paniekklachten’ en de 'Psychoeducatieve instructie op de Eerste Hulp post' ter preventie van paniekstoornis. Vooral afdelingen voor Eerste Hulp en Cardiologie van ziekenhuizen kunnen van zulke interventies baat hebben.

Al met al lijkt het opportuun om eerst te bepalen welke interventies bewezen effectief zijn, voor wie, en in welke settings. Twee angststoornissen verdienen daarbij in het bijzonder de aandacht: paniekstoornis en sociale fobie. Beide stoornissen komen vaak voor en gaan gepaard met een aanzienlijke ziektelast. Voor een breed landelijk implementatieplan voor preventie van angststoornissen lijkt het al met al het nog te vroeg. 



\section{PREVENTIE VAN ALCOHOLMISBRUIK EN -AFHANKELIJKHEID}

Dit hoofdstuk begint met een korte beschrijving van de kenmerken van alcoholmisbruik en -afhankelijkheid: definitie, beloop en doelgroepen voor preventie (paragraaf 5.1). Daarna geven we een overzicht van de epidemiologische kenmerken van alcoholmisbruik en -afhankelijkheid: omvang, ernst en gevolgen (5.2). De opbouw van de rest van dit hoofdstuk is enigszins anders dan die van de hoofdstukken over depressie en angststoornissen. Bij preventie van alcoholmisbruik en -afhankelijkheid spelen overheidsmaatregelen om schadelijk alcoholgebruik tegen te gaan een belangrijke rol. Deze specifieke vorm van universele preventie laat zich niet goed vangen binnen de gekozen leeftijdsgrenzen. Daarom staan deze maatregelen beschreven in een aparte paragraaf (5.3). In de daarop volgende paragrafen bespreken we de overige preventieve interventies voor jongeren (5.4), en voor volwassenen en ouderen (5.5). Omdat slechts enkele interventies zich specifiek richten op ouderen, hebben we in dit hoofdstuk geen aparte paragraaf over ouderen opgenomen. In de paragrafen 5.4 en 5.5 komen achtereenvolgens aan bod: de in Nederland beschikbare interventies, de gezondheidseffecten van effectieve interventies, en conclusies over de behaalbare gezondheidswinst van preventieve interventies. Het hoofdstuk eindigt met een samenvatting en conclusies (5.6). Alle in dit hoofdstuk aangehaalde interventies worden uitgebreider beschreven in bijlage 5 .

\subsection{Definitie, beloop en gevolgen van alcoholmisbruik en -afhankelijkheid}

De hieronder volgende informatie is grotendeels gebaseerd op bestaande overzichtsliteratuur voor kenmerken van alcoholmisbruik en -afhankelijkheid volgens de indeling van de DSM-IV(APA, 2001). Voor een uitgebreide beschrijving van kenmerken, duur en beloop van alcoholmisbruik en -afhankelijkheid verwijzen we naar deze overzichtsliteratuur. Het betreft ondermeer de volgende bronnen: APA (2001), Van den Brink (1999), NDM (2006), Schippers en Kaplan (2000) en Verdurmen et al., (2003). De diagnostische indeling van de DSM die we hier volgen, wordt echter niet altijd gevolgd in alcoholonderzoek, waar doorgaans verschillende operationalisaties voor 'probleemdrinken' fingeren (Van Dijck \& Knibbe, 2005). In hoofdstuk 2 gingen we hier al op in.

\section{Definitie}

Alcoholgerelateerde problematiek behoort volgens de DSM-IV (APA, 2001) tot de groep 'aan een middel gebonden stoornissen'. In de DSM wordt onderscheid gemaakt tussen alcoholmisbruik en alcoholafhankelijkheid. Bij alcoholmisbruik blijft de persoon bij voortduring alcohol drinken, hoewel dit schadelijke gevolgen heeft in de zin van fysiek gevaar, verwaarlozing van maatschappelijke verplichtingen, problemen met politie/justitie (alcoholgebruik in het verkeer) en/of interpersoonlijke problemen. Van 
alcoholafhankelijkheid wordt gesproken als de betrokkene aan minstens drie van de volgende criteria voldoet:

- tolerantie: gewenningsverschijnselen;

- onthoudingsverschijnselen bij plotseling stoppen met alcoholinname: trillen, slapeloosheid, misselijkheid, angst en soms hallucinaties of insulten;

- onvrede met het eigen drinkgedrag: meer of langer alcohol drinken dan gepland;

- tevergeefs willen stoppen of minderen met drinken;

- veel tijd nodig voor het herstel van de alcoholeffecten;

- opgeven of verminderen van sociale en beroepsmatige activiteiten vanwege alcoholgebruik;

- doorgaan met drinken ondanks de wetenschap dat lichamelijke of psychische problemen ontstaan of verergeren door het alcoholgebruik, bijvoorbeeld verzaken van verplichtingen of vertonen van riskant gedrag.

\section{Duur en beloop}

Alcoholmisbruik en alcoholafhankelijkheid zijn veel voorkomende stoornissen met een grillig en moeilijk voorspelbaar beloop (Van den Brink, 1999; Van Laar, 2005; Schippers \& Kaplan, 2000). Niet elk alcoholgebruik leidt tot overmatig gebruik of misbruik, en misbruik hoeft niet te leiden tot (chronische) afhankelijkheid. Overmatig alcoholgebruik of misbruik onder jonge mensen dooft voor een belangrijk deel uit naarmate de leeftijd vordert en men betrokken raakt bij werk en gezin. In een aantal gevallen leidt alcoholmisbruik tot vroege sterfte door verkeersongevallen.

Wanneer overmatig alcoholgebruik of misbruik bij jonge mensen blijft bestaan, lopen ze grote kans op middelbare leeftijd chronisch alcoholmisbruik of alcoholafhankelijkheid te ontwikkelen. Dit gaat gepaard met ernstig lijden en beperkingen in het sociaal of beroepsmatig functioneren.

Het beloop van alcoholmisbruik en -afhankelijkheid is vaak zeer wisselend, met frequente episodes van terugval die soms wel en soms niet leiden tot een blijvend staken van drankgebruik. Spontaan herstel is belangrijk, maar nauwelijks te voorspellen. De prognose van alcoholmisbruik is wat gunstiger dan die van alcoholafhankelijkheid.

Vroegtijdige herkenning en diagnostiek van alcoholmisbruik en alcoholafhankelijkheid is van belang, omdat behandeling in een vroeg stadium de beste kansen heeft. De vaak kortdurende interventies die voor probleemdrinken ontwikkeld zijn, lenen zich hier voor, maar het is dan moeilijk een grens te trekken tussen waar preventie eindigt en waar behandeling begint . Daarbij moeten we opmerken dat alcoholproblemen door professionals in de gezondheidszorg onvoldoende worden herkend. Op basis van ad hoc onderzoek wordt geschat dat tussen de 10 en 30\% van de personen met alcoholproblemen door de huisarts herkend wordt. Deze onderdiagnostiek wordt vooral veroorzaakt doordat problematisch alcoholgebruik weinig specifieke klachten en symptomen oplevert op de korte termijn (Meerkerk et al., 2005). 


\section{Doelgroepen voor preventie}

Er bestaat niet één oorzaak van alcoholmisbruik en -afhankelijkheid; het gaat altijd om een combinatie van elkaar beïnvloedende determinanten. De determinanten zoals die naar voren komen in epidemiologisch onderzoek zijn elders uitgebreid beschreven (Maas \& Jansen, 2000; Verdurmen et al., 2003). Hun onderlinge verbanden worden weergegeven in het Dynamisch Stress-kwetsbaarheidsmodel (Maas \& Jansen, 2000; Witte, 2004).

In deze paragraaf gaan we niet uitgebreid in op de afzonderlijke determinanten. We richten ons hier op concrete doelgroepen voor preventie. In deze doelgroepen komen meestal meerdere determinanten samen. Zoals beschreven in hoofdstuk 2 hanteren we bij het beschrijven van de doelgroepen de indeling in geïndiceerde, selectieve en universele preventie. Deze indeling moet niet al te strikt worden opgevat; verschillende doelgroepen zijn met verschillende vormen van preventie te benaderen. Daarnaast overlappen doelgroepen elkaar gedeeltelijk, waardoor sprake is van een extra hoog risico (Maas \& Jansen, 2000).

\section{Geïndiceerde preventie}

De doelgroep voor geïndiceerde preventie bestaat uit mensen met problematisch alcoholgebruik, die (nog) niet voldoen aan de diagnose alcoholmisbruik en -afhankelijkheid. Het zijn mensen die meer drinken dan de gangbare richtlijn voor verantwoord alcoholgebruik (Gezondheidsraad, 2005). Zij lopen een sterk verhoogde kans om alcoholmisbruik en -afhankelijkheid te ontwikkelen. Mensen met drankproblemen die daarnaast ook behoren tot een van de onderstaande doelgroepen voor selectieve of universele preventie lopen een sterk verhoogde kans op alcoholmisbruik en -afhankelijkheid.

\section{Selectieve preventie}

Voor selectieve preventie zijn in de praktijk de volgende twee specifieke doelgroepen van belang:

- Kinderen van verslaafde ouders. Alcoholafhankelijkheid op jonge leeftijd wordt voor het grootste deel bepaald door genetische factoren (Verdurmen et al., 2003). Ook opvoedingsfactoren spelen een rol. Het temperament van verslaafde ouders wordt in veel gevallen overgedragen op de kinderen en heeft vaak een negatieve invloed op het klimaat in het gezin (Van den Brink, 1999). Overigens hebben ook volwassen kinderen van probleemdrinkers een verhoogd risico op het ontwikkelen van alcoholmisbruik of -afhankelijkheid (Verdurmen et al., 2003).

- Mensen met andere psychische stoornissen. Andere psychische stoornissen - zoals angststoornissen, depressie of schizofrenie - gaan vaak vooraf aan alcoholafhankelijkheid (Maas \& Jansen, 2000; Monshouwer et al., 2002; Vollebergh et al., 2003).

\section{Universele preventie}

- Jongeren. Jongeren vormen de belangrijkste doelgroep voor preventie van alcoholmisbruik en -afhankelijkheid. Het is bekend dat Nederlandse jongeren veel en vaak drinken, zeker in verhouding tot hun leeftijdgenoten in andere landen (Monshou- 
wer et al., 2004). Dit heeft deels te maken met de sociaal-culturele waarden en normen in Nederland ten aanzien van alcoholgebruik. De sociale norm onder jongeren is dat het drinken van alcohol sterk gewenst is om 'erbij te horen', of 'stoer te zijn'. Daarbij komt dat de vrije toegang tot alcohol en de grote mate van tolerantie in het gebruik ervan - ook van overheidswege - nauwelijks een barrière vormen voor het overmatig drinken van alcohol (Maas \& Jansen, 2000; Van den Brink, 1999; Schippers \& Kaplan, 2000).

- Mannen. Mannen hebben een hoger risico op het ontwikkelen van alcoholmisbruik of -afhankelijkheid dan vrouwen (Bijl \& Ravelli, 1998). Dit geldt overigens sterker voor misbruik dan voor afhankelijkheid.

- Mensen met een lage sociaal-economische status. Deze mensen hebben vaak te kampen met een combinatie van risicofactoren, zoals stressvolle (sociaal-economische) levensomstandigheden of een ongezonde leefstijl. Een specifieke groep waarbij alcoholmisbruik en -afhankelijkheid veel voorkomt zijn dak- en thuislozen. Specifieke groepen van mensen met een lage sociaal-economische status zijn bijvoorbeeld terug te vinden in achterstandswijken of onder langdurig werklozen.

- Mensen met weinig sociale steun. Misbruik en afhankelijkheid van alcohol komt vaker voor bij personen die behoren tot een eenoudergezin of die alleen wonen (Van Laar, 2005; Maas \& Jansen, 2000).

\subsection{Omvang, ernst en gevolgen van alcoholmisbruik en -afhankelijkheid}

\section{Jaarprevalentie}

Per jaar komt alcoholmisbruik of -afhankelijkheid naar schatting voor bij minimaal $6,4 \%$ van de volwassen bevolking van Nederland (tabel 5.1). Het gaat dan om ongeveer 810 duizend volwassenen en ouderen. Onder volwassenen van $18 \mathrm{t} / \mathrm{m} 64$ jaar lijden per jaar ruim 808 duizend mensen aan alcoholmisbruik of -afhankelijkheid (7,8\%). Daarvan lijden er 447 duizend aan alcoholmisbruik en 363 duizend aan alcoholafhankelijkheid (Verdurmen et al., 2003). Over alcoholmisbruik en -afhankelijkheid bij ouderen zijn geen betrouwbare cijfers beschikbaar. Afgaand op de cijfers van een Europese studie lijkt het onder ouderen (65+ jaar) weinig voor te komen: bij ongeveer één op de duizend ouderen (Esemed, 2004). Cijfers over het zorggebruik laten echter juist een toename zien onder ouderen (Ladis, 2005). Onder jongeren komt alcoholafhankelijkheid naar eigen zeggen voor bij 3,1\% in de leeftijdsgroep 13 t/m 17 jaar (Verhulst et al., 1997). In totaal gaat het dan om zo'n 30 duizend jongeren. Over alcoholmisbruik bij jongeren zijn geen cijfers bekend. Het is wel bekend dat Nederlandse scholieren veel drinken vergeleken met scholieren uit andere landen (Verdurmen et al., 2005).

\section{Incidentie}

Per jaar ontwikkelt 2,1\% van de volwassen bevolking voor het eerst alcoholmisbruik of -afhankelijkheid (tabel 5.1). Dat zijn in totaal ongeveer 219 duizend volwassenen. Per jaar wordt bij 261 duizend volwassenen voor het eerst de diagnose alcoholmisbruik gesteld en bij 51 duizend volwassenen de diagnose alcoholafhankelijkheid. Incidentie- 
cijfers voor alcoholmisbruik en -afhankelijkheid bij jongeren en ouderen ontbreken. Echter, via extrapolatie van Amerikaanse cijfers naar de Nederlandse situatie zijn er naar schatting ongeveer 42 duizend jongeren die voor het eerst alcoholmisbruik of -afhankelijkheid ontwikkelen, en zijn er zo'n 46 duizend nieuwe gevallen van alcoholmisbruik- of afhankelijkheid bij ouderen van 65 tot 85 jaar (voor een uitleg van deze extrapolatie zie bijlage 2).

\section{Ziektelast}

De wegingsfactor voor misbruik is 0,11 ; die voor alcoholafhankelijkheid is 0,33 . Deze zijn voor jongeren (13 t/m17 jaar), volwassenen (18 t/m 64 jaar) en ouderen (65+ jaar) dezelfde. Daarmee staat alcoholmisbruik en -afhankelijkheid bij volwassenen in totaal voor bijna 116 duizend ziektejaarequivalenten (tekstblok 1.1). Voor jongeren en ouderen kunnen slechts met moeite ziektejaarequivalenten berekend worden voor alcoholmisbruik en -afhankelijkheid samen: bij jongeren zijn er geen maandprevalenties beschikbaar voor alcoholmisbruik, en bij ouderen ontbreken betrouwbare maandprevalentiecijfers voor alcoholmisbruik en -afhankelijkheid. Het aantal ziektejaarequivalenten voor alleen alcoholafhankelijkheid schatten we voor jongeren op bijna 7.300.

Volgens de Doodsoorzakenstatistiek van het CBS stierven in 2003 ruim 1.800 mensen aan oorzaken waarbij alcohol expliciet werd genoemd, zoals afhankelijkheid, psychische stoornissen door gebruik van alcohol en alcoholische leverziekten (De Hollander et al., 2006; NDM, 2006). Daarnaast werden in 2003170 verkeersdoden geregistreerd bij wie alcoholgebruik in het spel was (NDM, 2006). Uitgaande van deze CBS-cijfers voor sterfte is het aantal verloren levensjaren in de volwassen bevolking ongeveer 15.600. Daarmee komt het totaal aantal DALY's voor alcoholmisbruik of -afhankelijkheid voor de volwassen bevolking op minimaal 131.300. Afgaande op de cijfers van het CBS komt alcoholsterfte het meest voor in de leeftijdsgroep 50 tot en met 64 jaar.

Wanneer de ziektejaarequivalenten door alcoholafhankelijkheid bij jongeren en de verloren levensjaren door alcoholgebruik bij jongeren en ouderen hierbij opgeteld wordt, komt het totaal aantal DALY's voor alcoholmisbruik of -afhankelijkheid op minimaal 141.200. De ziektelast voor het aantal nieuwe gevallen van alcoholmisbruik en -afhankelijkheid bedroeg minimaal 47.800 DALY’s (tabel 5.1).

De CBS-cijfers geven waarschijnlijk een forse onderschatting van de werkelijke sterfte ten gevolge van alcoholmisbruik en -afhankelijkheid. De bijdrage van alcoholgebruik aan sterfte door andere aandoeningen wordt niet altijd herkend.

\section{Zorggebruik}

Mensen met alcoholmisbruik of -afhankelijkheid zoeken meestal geen hulp. Slechts een op de vijf volwassenen maakt binnen een periode van één jaar gebruik van enigerlei zorg (Bijl \& Ravelli, 1998; NDM, 2006). Een op de acht volwassenen met alcoholmisbruik of -afhankelijkheid bezocht de eerstelijn (12\%), ongeveer een op de twaalf bezocht de ambulante GGZ (9\%). Slechts $1 \%$ van de mensen met alcoholmisbruik of 
-afhankelijkheid werd daarvoor opgenomen in de GGZ. Van jongeren en ouderen met alcoholproblematiek zijn dergelijke cijfers niet bekend.

\section{Zorgkosten}

De bronnen van de Kosten van Ziekten-studie (Slobbe et al., 2006) laten een uitsplitsing van alcohol- en drugsproblematiek helaas niet toe. Hieronder geven we daarom de cijfers voor misbruik en afhankelijkheid van alcohol en drugs samen. Deze cijfers geven dus een overschatting van de werkelijke zorgkosten voor alcoholmisbruik en -afhankelijkheid. In 2003 werd ongeveer 356 miljoen euro uitgegeven aan zorgkosten samenhangend met misbruik en afhankelijkheid van alcohol en drugs (Slobbe et al., 2006). Dat was $0,6 \%$ van het totaal van 57,5 miljard aan zorgkosten, en ongeveer $3 \%$ van de 12,6 miljard euro die werd besteed aan de zorg voor mensen met psychische stoornissen (inclusief verstandelijke handicap). Bijna driekwart van de zorgkosten voor misbruik en afhankelijkheid alcohol en drugs (260 miljoen euro) werd besteed aan mannen.

Ongeveer 2\% van deze 356 miljoen euro - 7,4 miljoen euro - ging naar kinderen en jongeren tussen 0 en 19 jaar. Het overgrote deel - 313 miljoen euro (88\%) - werd besteed aan de zorg voor volwassenen tussen 20 en 64 jaar. Ongeveer 36 miljoen euro ging naar de zorg voor ouderen met misbruik of afhankelijkheid van alcohol of drugs (10\%).

Voor de schatting van de incidente kosten hebben we gebruik gemaakt van een andere studie, gebaseerd op Nemesis (Smit et al., in druk; tekstblok 2.1). Deze studie geeft onder andere een schatting van de directe zorgkosten voor volwassenen bij alcoholmisbruik en -afhankelijkheid. De directe zorgkosten voor het aantal nieuwe gevallen van alcoholmisbruik en -afhankelijkheid bij volwassenen bedroegen in 2003 bijna 33 miljoen euro (tabel 5.1).

\section{Ziekteverzuim en kosten van ziekteverzuim}

Het ziekteverzuim van probleemdrinkers ligt twee tot zes keer hoger dan gemiddeld (NIGZ, 2006). De jaarlijkse kosten als gevolg van productieverlies door ziekteverzuim bij alcoholmisbruik of -afhankelijkheid zijn bijna 1.250 euro per hoofd van de volwassen bevolking (Smit et al., in druk). Bij een aantal van 808.100 volwassenen met alcoholmisbruik of -afhankelijkheid is dit jaarlijks gemiddeld ongeveer 1 miljard euro (tabel 5.1). Bovendien is het waarschijnlijk dat mensen met alcoholmisbruik of -afhankelijkheid die wèl naar hun werk gaan, daar minder productief zijn. Dat leidt dan tot extra productieverliezen. De jaarlijkse kosten voor productieverliezen van het aantal nieuwe gevallen van alcoholmisbruik of -afhankelijkheid zijn ongeveer 274 miljoen euro.

\section{Arbeidsongeschiktheid}

Alcoholproblematiek lijkt wat betreft de instroom in de arbeidsongeschiktheidswetten een zeer bescheiden probleem. Mogelijk is hier sprake van een onderschatting, omdat alcoholproblemen vaak verborgen worden gehouden en daardoor mogelijk niet worden herkend door de verzekeringsarts. Het geregistreerde aantal arbeidsongeschikten 
als gevolg van alcoholproblematiek is waarschijnlijk een onderschatting van de werkelijkheid. Bovendien zullen een aantal mensen met alcoholmisbruik of -afhankelijkheid onder de diagnose depressie als arbeidsongeschikt geregistreerd worden, omdat ze vaak ook een depressie hebben. De registratie van uitkeringen voor arbeidsongeschiktheid van het UWV (2002) geeft cijfers over psychische en gedragsstoornissen door alcohol; deze zijn gebaseerd op de ICD-10. Mogelijk verschilt deze diagnose enigszins van de DSM-diagnose alcoholmisbruik en -afhankelijkheid.

Van de 993 duizend mensen die in 2002 arbeidsongeschikt waren kregen slechts 4 duizend van de verzekeringsarts de diagnose 'psychische en gedragsstoornissen door alcohol' (0,4\%). Van de 358 duizend arbeidsongeschikten met een diagnose binnen de hoofdgroep psychische stoornissen is dat ongeveer één op de negentig. Het overgrote deel van deze 4 duizend - 3.600 - zat in de WAO; 85\% van hen was volledig arbeidsongeschikt. In alle drie de arbeidsongeschiktheidswetten waren mannen sterk oververtegenwoordigd (ongeveer vijf zesde deel was man). Van de 108 duizend nieuwe arbeidsongeschikten in 2002 kregen ruim 4 honderd $(0,4 \%)$ de diagnose 'psychische of gedragsstoornissen door alcohol' (tabel 5.1). Het aantal arbeidsongeschikten met psychische en gedragsstoornissen door alcohol is niet toe- of afgenomen in 2002: de jaarlijkse instroom (400) was in 2002 gelijk aan de uitstroom (400).

\section{Overige gevolgen}

Eén van de meest ernstige maatschappelijke gevolgen van alcoholmisbruik en -afhankelijkheid is het rijden onder invloed. Circa $10 \%$ van het aantal verkeersongelukken is direct of indirect te wijten aan het gebruik van alcohol (NDM, 2006). Van ten minste $10 \%$ van de verkeersongevallen met dodelijke afloop staat vast dat ze voor rekening komen van alcohol, maar dit is een forse onderschatting. Bij veel criminaliteit (mishandeling, vandalisme, vermogensdelicten) is alcoholgebruik bovendien een belangrijke factor; circa een kwart van alle misdaden wordt gepleegd onder invloed, vaak met omvangrijke economische gevolgen (KPMG, 2001).

\section{Omvang, ernst en gevolgen alcoholmisbruik en -afhankelijkheid samengevat}

Jaarlijks zijn er minimaal 810 duizend mensen met alcoholmisbruik of -afhankelijkheid, exclusief een onbekend aantal jongeren met alcoholmisbruik (tabel 5.1). Die 810 duizend mensen vertegenwoordigen minimaal 141.200 DALY's. De totale zorgkosten van alcoholmisbruik en -afhankelijkheid bedraagt jaarlijks ruim 356 miljoen euro. Daarnaast genereren ze ruim 1 miljard euro aan kosten als gevolg van ziekteverzuim. Het aantal arbeidsongeschikten als gevolg van alcoholmisbruik en -afhankelijkheid was in 2002 zo'n 4 duizend. De zorgkosten voor nieuwe gevallen van alcoholmisbruik en -afhankelijkheid voor volwassenen bedragen jaarlijks zo'n 33 miljoen euro; daarnaast genereren deze volwassenen ongeveer 274 miljoen euro aan kosten als gevolg van ziekteverzuim. In hoeverre deze omvang, ernst en gevolgen kunnen worden gereduceerd met behulp van preventie, hangt af van de beschikbaarheid van effectieve interventies en het bereik daarvan. Dat is het onderwerp van de volgende paragrafen. 
Tabel 5.1: Alcoholmisbruik en -afhankelijkheid: omvang, ernst en gevolgen per jaar.

\begin{tabular}{|c|c|c|c|c|}
\hline & Jongeren & Volwassenen & Ouderen & Totaal \\
\hline \multicolumn{5}{|l|}{ Prevalente gevallen } \\
\hline \multicolumn{5}{|l|}{ Omvang } \\
\hline Jaarprevalentie $^{\text {a }}$ & $3,1^{b}$ & 7,8 & 0,1 & 6,4 \\
\hline $\begin{array}{l}\% \\
\text { aantal }\end{array}$ & $30.000^{b}$ & 808.100 & 1.500 & $809.600^{c}$ \\
\hline \multicolumn{5}{|l|}{ Ernst en gevolgen } \\
\hline $\begin{array}{l}\text { Ziektelast }^{\text {a }} \\
\quad \text { aantal DALY's }{ }^{\text {d }}\end{array}$ & $7.300^{b}$ & 131.300 & 2.600 & $141.200^{c}$ \\
\hline $\begin{array}{l}\text { Kosten (in mln euro) } \\
\text { zorgkosten ef } \\
\text { kosten door ziekteverzuim } \mathrm{g}\end{array}$ & $\begin{array}{l}7,4 \\
-\end{array}$ & $\begin{array}{l}313,0 \\
1.007,7\end{array}$ & $\begin{array}{l}35,9 \\
-\end{array}$ & $\begin{array}{l}356,4 \\
-\end{array}$ \\
\hline Arbeidsongeschiktheid ${ }^{\mathrm{h}}$ & - & 4.000 & - & - \\
\hline \multicolumn{5}{|l|}{ Incidente gevallen } \\
\hline \multicolumn{5}{|l|}{ Omvang } \\
\hline \multicolumn{5}{|l|}{ Ernst en gevolgen } \\
\hline $\begin{array}{l}\text { Ziektelast } \\
\quad \text { aantal DALY's d e }\end{array}$ & $2.400^{\mathrm{h}}$ & 45.400 & onbekend & $47.800^{\mathrm{i}}$ \\
\hline \multicolumn{5}{|l|}{ Kosten (in mln euro) } \\
\hline zorgkosten ${ }^{\mathrm{j}}$ & - & 32,9 & - & - \\
\hline kosten door ziekteverzuim ${ }^{j}$ & - & 273,5 & - & - \\
\hline
\end{tabular}

a Leeftijdsgroepen: 13-17jaar (Verhulst et al., 1997), 18-64 jaar (Bijl et al., 1997a) en 65+ jaar (Esemed, 2004).

b Deze cijfers zijn alleen gebaseerd op alcoholafhankelijkheid, en dus exclusief alcoholmisbruik.

c Deze cijfers zijn exclusief alcoholmisbruik bij jongeren en zijn dus een onderschatting van de werkelijkheid.

d Wegingsfactor $=0,11$ voor alcoholmisbruik en 0,33 voor alcoholafhankelijkheid; ziekteduur $=1$ jaar; zie voor een berekening tekstblok 1.1.

e Leeftijdsgroepen: 0-19 jaar, 20-64 jaar, 65+ jaar (Slobbe et al., 2006).

f Gebaseerd op Slobbe et al., 2006. Deze kosten zijn inclusief misbruik en afhankelijkheid van drugs.

g Prevalent verzuim volwassenen 18t/m64 jaar, gebaseerd op gegevens uit 2003 (Smit et al., in druk).

h Prevalente gevallen, gebaseerd op gegevens uit 2002 (UWV, 2002).

i Incidentie afgeleid van lifetime prevalentie (Kessler et al., 2005), in relatie tot incidentiecijfers van Nemesis (Bijl et al., 2002); zie voor een berekening bijlage 2. Deze cijfers zijn hoger dan op grond van de prevalentie-aantallen verwacht zou worden.

j Incidente kosten volwassenen 18t/m64 jaar, doorgerekend naar 2003 (Smit et al., in druk; tekstblok 2.1).

\subsection{Overheidsmaatregelen ter preventie van alcoholmisbruik en -afhankelijkheid}

De landelijke overheid heeft een wet- en regelgevende rol, bepaalt de hoogte van de accijnzen, maakt convenanten met de alcoholbranche en de horeca en is verantwoordelijk voor landelijke massamediale activiteiten. Jongeren zijn daarbij traditioneel een belangrijke doelgroep. Omdat alcoholgebruik maatschappelijk geaccepteerd is, vindt de overheid het belangrijk dat jongeren goed voorbereid worden op de om- 
gang met een middel dat risico's heeft voor de gezondheid en potentieel verslavend is. De overheid wil voorkomen dat jongeren op te jonge leeftijd gaan drinken. In haar alcoholbeleid wordt de overheid gesteund door het onderwijs en maatschappelijke organisaties die vanuit ideële overwegingen aandacht vragen voor de risico's van alcoholgebruik en verslaving.

\subsubsection{Overheidsmaatregelen ter preventie van alcoholmisbruik en -afhankelijkheid}

In het navolgende beschouwen we de overheidsmaatregelen in meer detail. Hier beschrijven we de maatregelen. Vervolgens vermelden we in paragraaf 5.3.2 de te verwachten gezondheidseffecten.

- Beschikbaarheid beperken. De landelijke overheid probeert de beschikbaarheid van alcohol te reguleren door middel van het stellen van leeftijdsgrenzen aan de verkoop van alcoholhoudende drank en door beperking van het aantal verkooppunten (met name op plaatsen waar het gebruik van alcohol risico's oplevert). Op grond van buitenlands onderzoek (Chisholm et al., 2004) is bekend dat beperking van beschikbaarheid een gezondheidswinst oplevert.

- Accijnsheffing. Via accijnsheffing wordt de prijs van alcohol verhoogd met als belangrijkste preventiedoel het voorkomen van schadelijk alcoholgebruik en alcoholgebruik op jonge leeftijd. Uit internationaal onderzoek blijkt dat het verhogen van prijzen van alcoholhoudende dranken, zoals via accijnsheffing, een kosteneffectieve manier is om de alcoholconsumptie terug te dringen (Babor et al., 2003; Chisholm et al., 2004).

- Blaastest bij verkeersdeelnemers. Wet- en regelgeving is het belangrijkste preventieinstrument om de alcoholschade in het verkeer te beperken (Wegenverkeerswet, Wet luchtverkeer en de Scheepvaartwet). De politie handhaaft de wetgeving in het verkeer, ondermeer door steekproefsgewijze alcoholcontroles bij automobilisten. Volgens Chisholm et al. (2004) zijn dergelijke interventies effectief.

- Reclamecode. De overheid heeft met alcoholbranche ook afspraken gemaakt over beperking van alcoholreclame. Er is een reclamecode voor alcoholhoudende drank ontwikkeld die werkt via zelfregulering. Voor de effectiviteit van dergelijke afspraken bestaat (nog) geen bewijs. Het onderzoek van Chisholm et al. (2004) laat zien dat een totaal verbod op alcoholreclame een effect kan hebben.

- Massamediale campagnes. De overheid voert verscheidene massamediale campagnes rond schadelijk alcoholgebruik:

- Het massamediale campagnes rond alcohol en verkeer (ministerie van Verkeer en Waterstaat in samenwerking met VVN). De algemene boodschap van deze campagnes is: 'Rij alcoholvrij'. De meest recente is de 'BOB-campagne'.

- Vanaf 1986 voert het ministerie van VWS onder de noemer 'Drank maakt meer kapot dan je lief is' een campagne. Doel: de bevolking wijzen op de risico’s van overmatig alcoholgebruik. De investering van 3,2 miljoen euro steekt overigens schril af tegen de ruim 220 miljoen euro die de alcoholbranche jaarlijks uitgeeft aan reclame om het alcoholgebruik aan te moedigen. 
- Sinds 1996 worden de campagnes door het Nationale Instituut voor Gezondheidsbevordering en Ziektepreventie (NIGZ) in samenwerking met regionale instellingen voor verslavingszorg en GGD-en uitgevoerd. Voorbeelden van campagnes van de afgelopen jaren zijn: 'Alcohol Mondjesmaat' (1987); 'Do you know, Do you care?' (1990); 'Ben jij sterker dan drank?' (1997) en 'Wat doet drank met u? (2000). De meest recente campagne is: 'Drank, de kater komt later'. Het belangrijkste doel van al deze campagnes is persoonlijke agendasetting (het denken en praten over het onderwerp) en bewustwording van de risico's van overmatig alcoholgebruik.

- Convenanten. Met de horeca zijn afspraken gemaakt over verantwoord schenken in horecagelegenheden. Bedrijfleiders en managers van horecagelegenheden moeten verplicht een cursus 'sociale hygiëne' volgen, waarin verantwoord schenken van alcohol centraal staat. Zo mag aan minderjarigen (jonger dan 16 jaar) geen alcoholische drank geschonken worden. Echter, volgens onderzoek van Bieleman (2006) lukt het minderjarigen in 94\% van hun pogingen om alsnog alcohol geschonken te krijgen.

\subsubsection{Gezondheidseffecten van overheidsmaatregelen ter preventie van alcoholmisbruik en -afhankelijkheid}

Er is in Nederland niet of nauwelijks onderzoek gedaan naar het effect van de ingezette overheidsmaatregelen op het reduceren van schadelijk alcoholgebruik. Het is dus onbekend welke maatregelen in de Nederlandse context effectief zijn en welke niet (Busch \& Planken, 2005; De Zwart, 1998). We moeten daarom gebruik maken van internationaal onderzoek (Babor et al., 2003; Chisholm et al., 2004) om tot ruwe schattingen te komen voor de behaalde en te behalen gezondheidswinst van een aantal van deze maatregelen in Nederland. De conclusies van beide studies stemmen overeen. Zowel Chisholm et al. (2004) als Babor et al. (2003) concluderen op basis van internationaal onderzoek dat het verminderen van de beschikbaarheid van alcohol, accijnsheffing en blaastesten bij verkeersdeelnemers effectieve manieren zijn om het alcoholgebruik terug te dringen. De bevindingen van Chisholm et al. worden hieronder besproken en staan vermeld in tabel 5.2.

- Beschikbaarheid beperken. Chisholm et al. (2004, p. 789) berekenden dat beperking van beschikbaarheid door in de weekenden geen winkelverkoop van alcohol toe te staan per 1 miljoen mensen uit de bevolking een gezondheidswinst oplevert van 251 DALY's. Geprojecteerd op de Nederlandse bevolking van 12 jaar en ouder - dit zijn 13,8 miljoen mensen - gaat het om een gerealiseerde gezondheidswinst van ongeveer 3.500 DALY's (zie tabel 5.2).

- Accijnsverhoging. De relatie tussen prijs en alcoholconsumptie wordt uitgedrukt in 'prijselasticiteit'. De prijselasticiteit van de vraag wordt gedefinieerd als het percentage verandering in consumptie als gevolg van een $1 \%$ verandering in prijs. De prijselasticiteit is per land verschillend en is ook verschillend voor typen alcohol (bier, wijn, gedistilleerd). De prijselasticiteit zoals geschat over verschillende landen loopt uiteen van $-0,08$ tot $-2,03$ voor gedistilleerd, van $-0,05$ tot $-1,65$ voor wijn en van 0 tot $-3,0$ voor bier (Österberg, 1995). Op basis van dit soort gegevens berekenden 
Chisholm et al. (2004) dat accijnsverhoging met een extra 25\% leidt tot 1.576 gewonnen DALY's per 1 miljoen mensen. Een accijnsverhoging met een extra 50\% leidt tot 1.764 DALY's per 1 miljoen mensen. Geprojecteerd op de 13,8 miljoen Nederlanders van 12 jaar en ouder, gaat het om een realiseerbare gezondheidswinst van 21.700 bij een accijnsverhoging van $25 \%$ en 24.300 DALY's bij een accijnsverhoging van $50 \%$.

- Blaastest bij verkeersdeelnemers. Volgens Chisholm et al (2004) zouden er 247 DALY's gewonnen worden per 1 miljoen mensen als de politie in elke regio veelvuldig alcoholcontroles uit zou voeren onder automobilisten. Geprojecteerd op de 12,6 miljoen Nederlanders van 18 jaar en ouder zou de behaalbare gezondheidswinst van deze maatregel in Nederland ongeveer 3.100 DALY's zijn.

- Reclamecode. Chisholm et al. (2004) berekenden dat het verbieden van reclame voor alcoholhoudende dranken een gezondheidswinst van 460 DALY's per 1 miljoen mensen zou opleveren. Geprojecteerd op de Nederlandse bevolking van 12 jaar en ouder, 13,8 miljoen, zou de behaalbare gezondheidswinst van deze maatregel in Nederland ongeveer 6.300 DALY's zijn.

- Massamediale campagnes. Uit evaluatieonderzoek blijkt dat de alcoholmatigingscampagnes een grote bekendheid genieten en er goed in slagen om persoonlijke agendasetting en bewustwording te bewerkstelligen (Rijksvoorlichtingsdienst, 2003; Cuijpers et al., 2005a). De massamediale campagnes hebben echter weinig invloed op het daadwerkelijke alcoholgebruik (Cuijpers et al., 2005a). Omdat we in dit rapport alleen naar het effect op stoornisspecifieke uitkomstmaten kijken, is de wetenschappelijke status van deze interventies toch slechts beperkt (tabel 5.4).

Tabel 5.2: Overheidsmaatregelen: gezondheidswinst in te winnen DALY's per maatregel.

\begin{tabular}{lc}
\hline Overheidsmaatregel & $\begin{array}{c}\text { Te behalen gezondheidswinst in DALY's } \\
\text { (wegingsfactor 0,15) }\end{array}$ \\
\hline Beschikbaarheid beperken (niet in weekends) & 3.500 \\
Accijnsverhoging met een extra 25\% & 21.700 \\
Accijnsverhoging met een extra 50\% & 24.300 \\
Vaker blaastesten bij automobilisten & 3.100 \\
Volledig verbod op reclame voor alcohol & 6.300 \\
\hline
\end{tabular}

a In het betreffende onderzoek (Chisholm et al., 2004) werd uitgegaan van een wegingsfactor van 0,15.

We kunnen concluderen dat er veel gezondheidswinst te behalen is door intensivering van overheidsmaatregelen, zoals verhoging van de accijns op alcohol en het handhaven van de wettelijke maatregelen. Dit zijn tevens de meest kosteneffectieve maatregelen. 


\subsection{Preventieve interventies voor alcoholmisbruik en -afhankelijkheid bij jongeren}

In deze paragraaf geven we een samenvatting van de in Nederland beschikbare preventieve interventies voor alcoholmisbruik en -afhankelijkheid bij jongeren. In paragraaf 5.4.1 komen de in Nederland beschikbare interventies aan bod. De interventies zijn ingedeeld in universele, selectieve en geïndiceerde preventie (paragraaf 2.3). Aan het eind van deze paragraaf staat een tabel met alle beschikbare interventies ter preventie van alcoholmisbruik en -afhankelijkheid bij jongeren (tabel 5.3). Paragraaf 5.4.2 beschrijft gezondheidseffecten van die interventies die in een gerandomiseerde studie geëvalueerd zijn, inclusief conclusies over de behaalbare gezondheidswinst. Voor een uitgebreide beschrijving van de in Nederland beschikbare interventies ter preventie van alcoholmisbruik en -afhankelijkheid bij jongeren verwijzen we naar bijlage 5. De beoordeling op wetenschappelijke status en ontwikkelingsfase staat beschreven in paragraaf 2.4 .

\subsubsection{In Nederland beschikbare interventies ter preventie van alcoholmisbruik en -afhankelijkheid bij jongeren}

\section{Universele preventie}

Voor leerlingen in het voortgezet onderwijs worden in Nederland twee vormen van universele alcoholpreventie vaak aangeboden.

- De interventie 'De gezonde school en genotmiddelen' (Cuijpers et al., 2002) is een breed genotmiddelenpreventieprogramma. Het programma bestaat uit een serie lessen in het voortgezet onderwijs waar alcoholpreventie een onderdeel van vormt. Een uitgebreide quasi-experimentele effectstudie toonde aan dat het programma een gunstig effect heeft op de kennis, houding en vaardigheden met betrekking tot alcoholgebruik (Cuijpers et al., 2002, Smit et al., 2003b). Ook leidt het programma tot een reductie in alcoholgebruik; dit effect houdt tenminste drie jaar aan. Momenteel loopt er een gerandomiseerd onderzoek naar de interventie.

Ontwikkelingsfase: G. Wetenschappelijke status: **.

- Het recent gestarte project 'Alcohol en opvoeding' heeft als doel advies en ondersteuning aan ouders te bieden om alcoholgebruik bij kinderen op jonge leeftijd te voorkomen. Het project combineert verschillende grote landelijke programma's; een deelcampagne van de NIGZ-alcoholcampagne en het programma 'De gezonde school en genotmiddelen' van het Trimbos-instituut (zie hierboven). Onderzoek naar deze interventie is nog niet gedaan: de wetenschappelijke status is gebaseerd op de status van de reeds onderzochte onderdelen.

Ontwikkelingsfase: I. Wetenschappelijke status: **.

- Het 'Preventief GezondheidsOnderzoek' wordt door verschillende GGD-en uitgevoerd. en heeft tot doel het stimuleren van gezond gedrag. Hierbij wordt ook aandacht besteed aan preventie van alcoholmisbruik en -afhankelijkheid. De doelgroep bestaat uit leerlingen uit de $1^{\mathrm{e}}$ en $2^{\mathrm{e}}$ klas van het voortgezet onderwijs. Ontwikkelingsfase: G. Wetenschappelijke status: niet effectief. 
Er is overigens in toenemende mate aandacht voor de rol van de ouders bij het reguleren van het drankgebruik van hun kind. Onderzoek heeft aangetoond dat teveel ouders alcoholgebruik bij hun kinderen toestaan en zich onvoldoende realiseren dat hun kinderen daardoor vormen van blijvende gezondheidsschade kunnen oplopen. Zo zegt 36\% van de scholieren in de groepen zeven en acht op de basisschool thuis te mogen drinken, en dit cijfer loopt op tot $68 \%$ bij scholieren op het voortgezet onderwijs (Monshouwer et al., 2004). Bovendien realiseren teveel ouders zich onvoldoende dat zij als ouder bij uitstek invloed op hun kinderen kunnen uitoefenen, ook ten aanzien van alcoholgebruik (Van der Vorst et al., 2005, 2006). Dit thema is in de media en door VWS opgepakt, en als gevolg daarvan heeft het Trimbos-instituut nu een project in voorbereiding over alcohol en opvoedingsondersteuning.

\section{Selectieve preventie}

- Het NIGZ voert onder de titel 'Drank, de kater komt later' een preventieproject uit, gericht op veeldrinkende jongeren die uitgaan of op vakantie zijn. Het betreft een combinatie van massamediale activiteiten en peereducatie. Doel is het voorkomen van overmatig alcoholgebruik door jongeren in hun vrije tijd. Er werden meerdere (quasi-) experimentele effectstudies uitgevoerd (Cuijpers et al., 2005a). Er worden effecten op kennis, attitude en intentie gevonden. Alcoholgebruik lijkt echter niet beïnvloed te worden, waardoor de wetenschappelijks status van deze intereventie toch slechts beperkt is.

Ontwikkelingsfase: G. Wetenschappelijke status: *.

- In het kader van het project 'Resultaten Scoren' werd in 1998 de 'Homeparty' ontwikkeld (Bolier et al., 2004; Riper et al., 2004). De doelgroep bestaat uit gezinnen uit achterstandswijken en gezinnen met een niet-Nederlandse achtergrond. Het doel van de interventie is om ouders te leren omgaan met het experimenteren en gebruiken van genotmiddelen van hun kinderen.

Ontwikkelingsfase: G. Wetenschappelijke status: *.

- 'Kinderen van Verslaafde Ouders'. Kinderen van verslaafde ouders vormen een risicogroep voor het ontwikkelen van alcoholproblemen (Van den Boer et al., 2002; Vos et al., 2002). Voor deze doelgroep zijn de Kinderen van Verslaafde Ouders (KVO) kinder- en pubergroepen ontwikkeld. Het doel van de cursus is het doorbreken van het isolement van deze kinderen, het bevorderen van een reële kijk op zichzelf en de ouder en kinderen beter leren omgaan met negatieve reacties en eigen gevoelens (Beurskens \& Siebes, 1998).

Ontwikkelingsfase: G. Wetenschappelijke status: *.

- 'Drankjewel' (www.drankjewel.nl; Riper \& Conijn, 2003) is een website voor kinderen van ouders met alcoholproblemen. Doel van de website is kinderen te informeren en hen te helpen om met hun problemen om te gaan.

Ontwikkelingsfase: G. Wetenschappelijke status: *.

- Het programma 'Uitgaan en drugs' is een integrale aanpak om riskant alcoholen drugsgebruik tijdens het uitgaan tegen te gaan (Bolier et al., 2005), en zo de (gezondheids)schade van alcohol- en drugsgebruik te beperken. Het programma richt zich op jongeren en jong volwassenen die overmatig drinken, al of niet in combinatie met het gebruik van uitgaansdrugs. Het programma bestaat uit een 
monitoringinstrument, een module netwerkontwikkeling in het uitgaanscircuit, een cursus voor horecapersoneel, voorlichting voor uitgaanders en een cursus Eerste Hulp bij Drugsongevallen in het uitgaanscircuit.

Ontwikkelingsfase: G. Wetenschappelijke status: *

- 'Big deal' is een project gebaseerd op 'peer-educatie', waarbij vrienden kennis en inzichten over het gebruik van genotmiddelen met elkaar delen en bespreken (Blitterswijk, 2004). Het primaire doel is kennisoverdracht.

Ontwikkelingsfase: G. Wetenschappelijke status: *

\section{Geïndiceerde preventie}

Er zijn in Nederland geen interventies beschikbaar voor geïndiceerde preventie van alcoholmisbruik en -afhankelijkheid bij jongeren.

Tabel 5.3: Overzicht van in Nederland beschikbare interventies ter preventie van alcoholmisbruik en -afhankelijkheid van jongeren.

\begin{tabular}{|c|c|c|c|c|c|}
\hline & $\begin{array}{l}\text { Soort } \\
\text { interventie }^{a}\end{array}$ & $\begin{array}{l}\text { Ontwik- } \\
\text { kelings } \\
\text { fase }^{\text {b }}\end{array}$ & $\begin{array}{l}\text { Weten- } \\
\text { sch. } \\
\text { status c }\end{array}$ & $\begin{array}{l}\text { Uit- } \\
\text { komst- } \\
\text { maat d }\end{array}$ & Doelgroep \\
\hline \multicolumn{6}{|l|}{ Universeel } \\
\hline $\begin{array}{l}\text { Massamediale } \\
\text { campagnes } \\
\text { (overheid) }\end{array}$ & media & G & * & $\mathrm{K}$ & $\begin{array}{l}\text { Nederlandse bevolking of } \\
\text { brede groepen daaruit }\end{array}$ \\
\hline $\begin{array}{l}\text { Gezonde school } \\
\text { en genotmiddelen }\end{array}$ & les & G & ** & $\mathrm{K}$ & leerlingen VO \\
\hline $\begin{array}{l}\text { Alcohol en } \\
\text { opvoeding }\end{array}$ & media & I & ** & $\mathrm{K}$ & $\begin{array}{l}\text { ouders van jongeren die } \\
\text { drinken }\end{array}$ \\
\hline $\begin{array}{l}\text { Preventief } \\
\text { Gezondheids } \\
\text { Onderzoek }\end{array}$ & individueel & G & $\begin{array}{l}\text { niet ef- } \\
\text { fectief }\end{array}$ & $\mathrm{K}$ & leerlingen klas 1-2 VO \\
\hline \multicolumn{6}{|l|}{ Selectief } \\
\hline $\begin{array}{l}\text { Drank, de kater } \\
\text { komt later }\end{array}$ & peer-educatie & G & * & $\mathrm{K}$ & $\begin{array}{l}\text { veeldrinkende jongeren die } \\
\text { uitgaan of op vakantie zijn }\end{array}$ \\
\hline Homeparty & $\begin{array}{l}\text { voorlichting } \\
\text { in eigen taal } \\
\text { cultuur }\end{array}$ & G & * & $\mathrm{K}$ & $\begin{array}{l}\text { ouders van jongeren uit } \\
\text { achterstandswijken en } \\
\text { allochtonen }\end{array}$ \\
\hline $\begin{array}{l}\text { Kinderen van Ver- } \\
\text { slaafde Ouders }\end{array}$ & groep & G & * & $\mathrm{K}$ & $\begin{array}{l}\text { kinderen van verslaafde } \\
\text { ouders }\end{array}$ \\
\hline $\begin{array}{l}\text { Drankjewel } \\
\text { jongeren }\end{array}$ & internet & G & * & $\mathrm{K}$ & $\begin{array}{l}\text { kinderen van ouders met } \\
\text { drankproblemen }\end{array}$ \\
\hline Uitgaan en drugs & $\begin{array}{l}\text { integrale } \\
\text { aanpak }\end{array}$ & G & * & $\mathrm{K}$ & $\begin{array}{l}\text { jongeren (en jong-volwasse- } \\
\text { nen) die overmatig drinken, } \\
\pm \text { uitgaansdrugs }\end{array}$ \\
\hline Big deal & peer-educatie & G & * & $\mathrm{K}$ & jongeren \\
\hline \multicolumn{6}{|l|}{ Geïndiceerd } \\
\hline \multicolumn{6}{|l|}{-} \\
\hline \multicolumn{6}{|c|}{$\begin{array}{l}\text { a Soort interventie: groep = groepscursus, internet = internetcursus, peer-educatie = kennisoverdracht via } \\
\text { vrienden en leeftijdsgenoten, integrale aanpak=combinatie van interventies. } \\
\text { b Ontwikkelingsfase: I= innovatief, G=gestandaardiseerd (paragraaf } 2.3 \text { ). } \\
\text { c Wetenschappelijke status: }{ }^{*}=\text { gepubliceerde mening van deskundigen, of mening van werkgroepleden, } \\
{ }^{* *}=\text { gebaseerd op één gerandomiseerd onderzoek of op meerdere onderzoeken zonder controlegroep } \\
\text { (paragraaf } 2.4 \text { ). }\end{array}$} \\
\hline
\end{tabular}




\subsubsection{Gezondheidseffecten van preventie van alcoholmisbruik en -afhankelijkheid bij jongeren}

Er zijn in Nederland geen bewezen effectieve interventies beschikbaar ter preventie van alcoholmisbruik en -afhankelijkheid bij jongeren. De universele interventie 'Gezonde school en genotmiddelen' lijkt een goede kandidaat, maar werd alleen in een quasiexperimenteel onderzoek geëvalueerd. Momenteel voert het Trimbos-instituut een grootschalig gerandomiseerd effectonderzoek uit naar deze interventie.

\subsection{Preventieve interventies voor alcoholmisbruik en -afhankelijkheid voor volwassenen en ouderen}

In deze paragraaf geven we een samenvatting van de in Nederland beschikbare preventieve interventies voor alcoholmisbruik en -afhankelijkheid bij volwassenen en ouderen. In paragraaf 5.5.1 komen de in Nederland beschikbare interventies aan bod. De interventies zijn ingedeeld in universele, selectieve en geïndiceerde preventie (zie hoofdstuk 2). Aan het eind van deze paragraaf staat een tabel met alle beschikbare interventies ter preventie van alcoholmisbruik en -afhankelijkheid bij volwassenen en ouderen (tabel 3.5). Paragraaf 5.5 .2 beschrijft gezondheidseffecten van die interventies die in een gerandomiseerde studie geëvalueerd zijn, inclusief conclusies over de behaalbare gezondheidswinst. Voor een uitgebreide beschrijving van de in Nederland beschikbare interventies ter preventie van alcoholmisbruik en -afhankelijkheid bij volwassenen en ouderen verwijzen we naar bijlage 5. Voor een uitleg van de beoordeling op wetenschappelijke status en ontwikkelingsfase verwijzen we naar hoofdstuk 2.

\subsubsection{In Nederland beschikbare interventies voor preventie van alcoholmisbruik en -afhankelijkheid bij volwassenen en ouderen}

De interventies die we hier beschrijven zijn gericht op volwassenen van 18 jaar en ouder. In Nederland worden geen interventies aangeboden ter preventie van alcoholmisbruik en -afhankelijkheid die zich specifiek richten op ouderen. Daarom is er geen aparte paragraaf opgenomen over ouderen. Voor de hieronder beschreven interventies geldt dat ze in principe ook bruikbaar zijn voor ouderen. Wel is bij de oudere doelgroep extra aandacht nodig voor de effecten van alcohol op oudere leeftijd. Door veranderingen in de vet en vochtverhouding in het lichaam, de verminderde werking van lever en nieren en een verminderde lichaamsweerstand leidt dezelfde hoeveelheid alcohol tot hogere bloedspiegels, lagere tolerantie en snellere intoxicatie en orgaanschade. Dit betekent dat voor ouderen het aantal glazen volgens de richtlijn voor verantwoord drinken vaak te hoog is (zie 'geïndiceerde preventie'). Daarnaast is de richtlijn niet zondermeer van toepassing op andere bijzondere groepen zoals zwangere vrouwen en volwassenen met aandoeningen zoals diabetes. 


\section{Universele preventie}

Universele preventie van alcoholmisbruik en -afhankelijkheid bij volwassenen en ouderen bestaan uit massamediale campagnes. Deze zijn besproken in paragraaf 5.3 over de overheidsmaatregelen.

\section{Selectieve preventie}

- De site ‘drankjewel’ (www.drankjewel.nl; Riper \& Conijn, 2003) is ontwikkeld voor volwassen kinderen van ouders met alcoholproblemen. Zij hebben een verhoogd risico om op latere leeftijd zelf alcoholproblemen te ontwikkelen. De site bestaat uit twee delen: één voor jongeren en één voor volwassen kinderen van probleemdrinkers. Doel van de site is het voorkomen van problemen als gevolg van de problematiek van de ouders. Drankjewel is sinds mei 2003 online. Het deel voor volwassenen is in 2005 maandelijks bezocht door 1.200 (unieke) bezoekers.

Ontwikkelingsfase: G. Wetenschappelijke status: *.

\section{Geïndiceerde preventie}

Geïndiceerde preventie van alcoholmisbruik en -afhankelijkheid richt zich op personen die meer drinken dan verantwoord is volgens de gangbare richtlijn zonder daarbij te voldoen aan diagnostische criteria van de DSM voor alcoholmisbruik en alcoholafhankelijkheid (Gezondheidsraad, 2004). De volgende interventies voor preventie van alcholmisbruik en -afhankelijkheid zijn in Nederland beschikbaar voor volwassenen en ouderen:

- 'De Drinktest'. De 'Drinktest' (www.drinktest.nl; Huiberts \& Boon, 2003a, 2003b) is bedoeld voor volwassenen die regelmatig drinken en hun drinkgedrag willen analyseren. Doel van de test is het informeren en adviseren van mensen die regelmatig alcohol drinken met een advies op maat. In een gerandomiseerde studie zijn de effecten onderzocht. Vrouwen die de drinktest hebben gedaan, drinken minder dan vrouwen die dit niet hebben gedaan. Voor mannen wordt geen verschil gevonden (Boon \& Huiberts, in voorbereiding, paragraaf 5.5.2). Via de website van de Drinktest kan men zonodig terecht bij het internet-zelfhulpprogramma 'Minder drinken' (zie beneden).

Ontwikkelingsfase: G. Wetenschappelijke status: **.

- Internet-zelfhulpprogramma 'Minder drinken'. Deze interventie (www.minderdrinken.nl; Riper et al., 2005) is een zelfhulpprogramma voor probleemdrinkers en wordt over het internet aangeboden. De doelgroep bestaat uit volwassen probleemdrinkers die graag zelfstandig willen minderen of stoppen met drinken zonder tussenkomst van een hulpverlener. MinderDrinken bestaat uit een zelfhulpprogramma en een deelnemersforum. Het zelfhulpprogramma heeft cognitief-gedragstherapeutische uitgangspunten; het deelnemersforum biedt de mogelijkheid om ervaringen uit te wisselen. In een gerandomiseerde studie zijn de effecten onderzocht. Personen die 'Minder Drinken' hebben gevolgd, drinken significant minder glazen alcohol per week en houden zich vaker aan de richtlijn voor verantwoord drinken (Riper et al., in voorbereiding, paragraaf 5.5.2).

Ontwikkelingsfase: G. Wetenschappelijke status: ${ }^{* *}$. 
- Zelfhulpcursus ‘Hoe minder te drinken’ (Van Emst, 1996). Dit is een zelfhulpboekje voor probleemdrinkers. De doelgroep bestaat ook hier uit volwassenen die zelfstandig iets aan het alcoholgebruik willen doen. In dit boekje wordt een gelijksoortige methodiek toegepast als in MinderDrinken (zie boven), maar dan in boekvorm. Ontwikkelingsfase: G. Wetenschappelijke status: *.

- Eind november 2006 zendt Teleac de cursus uit 'Minder drinken: doe het zelf', gebaseerd op diverse 'Minder Drinken' interventies. De uitzending wordt voorafgegaan door een gerandomiseerd onderzoek om zicht te krijgen op de effectiviteit van deze zelfhulpcursus. Dat onderzoek loopt nog. Ontwikkelingsfase: I. Wetenschappelijke status: *.

- De 'Educatieve Maatregel alcohol en verkeer' is een cursus die ontwikkeld is door het CBR. In 1996 is de cursus ingevoerd door het Ministerie van Verkeer en Waterstaat. De cursus richt zich op bestuurders bij wie een alcoholpromillage werd gemeten tussen de 1,3 en 1,8 (in geval van herhaling een promillage van 0,8). Evaluatieonderzoek toonde aan dat de interventie niet effectief is (Nägele \& Vissers, 2000). Ontwikkelingsfase: G. Wetenschappelijke status: niet effectief.

Vanuit verschillende instellingen voor verslavingszorg worden momenteel geïndiceerde preventieve interventies aangeboden, al dan niet via het internet. De mate van ondersteuning door een professionele hulpverlener en het aantal 'sessies' verschilt per programma. Deze interventies zijn gebaseerd op technieken uit de cognitieve gedragstherapie en motiverende gespreksvoering. Uit internationaal effectonderzoek blijkt dat kortdurende interventies behoren tot de meest effectieve vormen van hulpverlening voor mensen met beginnende alcoholproblemen (Miller \& Wilbourne, 2002; Moyer et al., 2002; Cuijpers et al., 2004). Onderstaande interventies zijn zelf niet op hun effect onderzocht, maar ze maken wel gebruik van methodieken die hun effect bewezen hebben.

- 'Alcohol de Baas'. Dit is een kortdurende internetbehandeling die aangeboden wordt via TACTUS Instelling voor Verslavingszorg. Deelname is geheel anoniem. Deelnemers doorlopen het programma via internet en via email is er contact met een hulpverlener. Deze hulpverlener houdt de vorderingen bij, motiveert de deelnemer en kan vragen beantwoorden. Momenteel loopt een effectonderzoek naar deze interventie.

Ontwikkelingsfase: G. Wetenschappelijke status: onbekend.

- 'Zelfhulpprogramma alcohol'. Jellinek (www.jellinek.nl) biedt via het internet zelfhulpmodules aan en start 15 november 2006 met het 'Zelfhulpprogramma alcohol'. Deze interventie bestaat uit de combinatie van een online programma en chatsessies met een hulpverlener. Na iedere stap krijgt de deelnemer gelegenheid om direct met een hulpverlener te chatten. In totaal bestaat de interventie uit zeven sessies. Er is een promotieonderzoek gestart om de effecten van de interventie te onderzoeken.

Ontwikkelingsfase: G. Wetenschappelijke status: onbekend.

- 'Behandeling online'. Brijder Verslavingszorg biedt via internet behandeling aan voor mensen die nog niet verslaafd zijn en anoniem willen minderen of stoppen. De behandeling bestaat uit een intake en negen sessies. De deelnemer wordt door een hulpverlener begeleid.

Ontwikkelingsfase: G. Wetenschappelijke status: onbekend. 
Tabel 5.4: Overzicht van in Nederland beschikbare interventies ter preventie van alcoholmisbruik en -afhankelijkheid bij volwassenen.

\begin{tabular}{|c|c|c|c|c|c|}
\hline & $\begin{array}{l}\text { Soort } \\
\text { inter- } \\
\text { ventie }^{a}\end{array}$ & $\begin{array}{l}\text { Ontwik- } \\
\text { kelings- } \\
\text { fase }^{b}\end{array}$ & $\begin{array}{l}\text { Wetensch. } \\
\text { status }{ }^{\mathrm{c}}\end{array}$ & $\begin{array}{l}\text { Uit- } \\
\text { komst- } \\
\text { maat d }\end{array}$ & Doelgroep \\
\hline \multicolumn{6}{|l|}{ Universeel } \\
\hline $\begin{array}{l}\text { Massamediale cam- } \\
\text { pagnes (overheid) }\end{array}$ & Media & G & * & $\mathrm{K}$ & $\begin{array}{l}\text { Nederlandse bevolking of } \\
\text { brede groepen daaruit }\end{array}$ \\
\hline \multicolumn{6}{|l|}{ Selectief } \\
\hline $\begin{array}{l}\text { Drankjewel } \\
\text { volwassenen }\end{array}$ & Internet & G & * & $\mathrm{K}$ & $\begin{array}{l}\text { volwassen kinderen van } \\
\text { probleemdrinkers }\end{array}$ \\
\hline \multicolumn{6}{|l|}{ Geïndiceerd } \\
\hline Drinktest & Internet & G & ** & $\mathrm{R}$ & volwassen alcoholgebruikers \\
\hline $\begin{array}{l}\text { Hoe minder te } \\
\text { drinken }\end{array}$ & Zelfhulp & G & $*$ & $\mathrm{R}$ & volwassen probleemdrinkers \\
\hline Minder drinken & Internet & G & ** & $\mathrm{R}$ & volwassen probleemdrinkers \\
\hline $\begin{array}{l}\text { Minder drinken: } \\
\text { doe het zelf }\end{array}$ & Teleac & I & - & $\mathrm{K}$ & volwassen alcoholgebruikers \\
\hline $\begin{array}{l}\text { Educatieve } \\
\text { Maatregel alcohol } \\
\text { en verkeer }\end{array}$ & Groep & G & $\begin{array}{l}\text { niet ef- } \\
\text { fectief }\end{array}$ & $\mathrm{K}$ & $\begin{array}{l}\text { automobilisten die teveel } \\
\text { gedronken hebben }\end{array}$ \\
\hline $\begin{array}{l}\text { Zelhulpprogramma } \\
\text { alcohol }\end{array}$ & Internet & G & onbekend & $\mathrm{K}$ & volwassen probleemdrinkers \\
\hline Behandeling online & Internet & G & onbekend & K & volwassen probleemdrinkers \\
\hline Alcohol de Baas & Internet & G & onbekend & K & volwassen probleemdrinkers \\
\hline
\end{tabular}

a Soort cursus: Groep = groepscursus, Zelfhulp = schriftelijke zelfhulpcursus, Internet = internetzelfhulpcursus.

b Ontwikkelingsfase: I = innovatief, $\mathrm{G}=$ gestandaardiseerd (paragraaf 2.3).

c Wetenschappelijke status: * = gepubliceerde mening van deskundigen, of mening van werkgroepleden, ${ }^{* *}=$ gebaseerd op één gerandomiseerd onderzoek of op meerdere onderzoeken zonder controlegroep (paragraaf 2.4).

${ }^{\mathrm{d}}$ Uitkomstmaat: $\mathrm{I}$ = effect op incidentie, $\mathrm{R}=$ effect op risicostatus (meer drinken dan de richtlijn voor verantwoord alcoholgebruik), $\mathrm{K}=$ effect op klachten (alcoholgebruik) (paragraaf 2.4).

\subsubsection{Gezondheidseffecten van preventie van alcoholmisbruik en -afhankelijkheid bij volwassenen en ouderen}

Anders dan bij studies naar preventie van depressie is effectonderzoek met vermindering van de incidentie volgens DSM criteria geen traditie bij alcoholgerelateerde stoornissen. Daarom zijn effecten op afname van incidentie nooit onderzocht voor alcoholmisbruik en -afhankelijkheid.

Van de bovenbeschreven interventies ter voorkoming van alcoholmisbruik en -afhankelijkheid bij volwassenen en ouderen zijn er drie in een Nederlandse gerandomiseerde studie onderzocht: de internetcursus 'MinderDrinken', de zelfhulpcursus 'Hoe minder te drinken' en de internetinterventie 'De Drinktest'. We bespreken deze studies om iets te kunnen zeggen over de behaalbare gezondheidswinst van de drie genoemde interventies. De uitkomstmaat is bij alle drie de studies verandering in risicostatus. 
Deze maat geeft aan of iemand meer drinkt dan de gangbare richtlijn voor verantwoord alcoholgebruik (Gezondheidsraad, 2005). Dit is voor mannen niet meer dan drie glazen per dag, en voor vrouwen niet meer dan twee. Bovendien zijn er geen dagen (bijvoorbeeld in het weekend) waarin mannen meer dan zes glazen drinken ('bingen'). Voor vrouwen is dit niet meer dan vier glazen.

\section{Internetcursus 'MinderDrinken'}

De interventie 'MinderDrinken' (www.minderdrinken.nl; Riper et al., 2005) is op effectiviteit onderzocht in een gerandomiseerd onderzoek onder 261 personen met een verhoogde risicostatus (Riper et al., in voorbereiding). De vraag was hoeveel personen door toedoen van de interventie hun risicostatus verliezen. Deelnemers werden random toegewezen aan MinderDrinken of aan een informatiebrochure op het internet ('Wat doet drank met u'; NIGZ, 2000). Tabel 5.5 laat zien dat er statistisch significante effecten zijn op de risicostatus voor alcoholmisbruik of -afhankelijkheid. In de interventiegroep verliest $15 \%$ de risicostatus tegen $5 \%$ in de controlegroep.

Tabel 5.5: Effectiviteit van de internetcursus 'MinderDrinken' op risicostatus na 12 maanden ${ }^{a}$.

\begin{tabular}{lccc}
\hline & & $\begin{array}{c}\text { Interventiegroep } \\
(\mathrm{n}=131)\end{array}$ & $\begin{array}{c}\text { Controlegroep } \\
(\mathrm{n}=130)\end{array}$ \\
\hline Behield risicostatus & & 112 & 123 \\
Verloor risicostatus & & 19 & 7 \\
Risico op de stoornis & & 0,85 & 0,95 \\
& & & \\
Risicoverschil (RV) & \multicolumn{2}{c}{$95 \% \mathrm{BI}$} & \\
Relatief risico (RR) & 0,09 & $(0,02 \sim 0,16)$ & \\
NNT & 0,90 & $(0,83 \sim 0,98)$ & \\
\hline
\end{tabular}

$\chi^{2}=6,05, p=0,01$

${ }^{\text {a }}$ Risicostatus = iemand drinkt meer dan de gangbare richtlijn voor verantwoord alcoholgebruik (Gezondheidsraad, 2005). Gemeten met: 'Weekly recall, Binge drinken' (Riper et al., in voorbereiding ).

Voor een uitleg van deze tabel zie tekstblok 2.3 .

De website is in 11 maanden bezocht door 18.653 unieke personen. Hiervan namen 4.511 personen (24\%) actief deel aan de interventie. Op jaarbasis correspondeert dit met 4.920 actieve deelnemers. Bij een risicoverschil van $9 \%$ gaan onder invloed van de interventie en in vergelijking tot de controlegroep, jaarlijks 443 personen zodanig minder drinken dat zij hun ongunstige risicostatus verliezen.

Op basis van deze effectstudie is momenteel ook een kosteneffectiviteitstudie in voorbereiding. De eerste en voorlopige resultaten daarvan doen vermoeden dat 'Minder drinken' een kosteneffectieve interventie is (Smit et al., aangeboden ter publicatie).

\section{Zelfhulpcursus 'Hoe minder te drinken'}

Het boekje 'Hoe minder te drinken' (Van Emst, 1996) is op effectiviteit onderzocht in een gerandomiseerd onderzoek onder 175 personen die meer dronken dan de gang- 
bare richtlijn voor verantwoord alcoholgebruik (Kramer \& Riper, 2005). Via loting werd bepaald of deelnemers het boekje kregen toegestuurd (interventiegroep) of een informatiebrochure 'Wat doet drank met u' (NIGZ, 2000; vergelijkingsgroep). Bij de voormeting dronk men gemiddeld 41,1 glazen per week in de conditie van het boekje en 41,3 in die van de brochure. Na een half jaar dronk men respectievelijk 32,9 glazen in de interventiegroep en 37,6 in de vergelijkingsgroep. In de interventiegroep verminderde het alcoholgebruik significant meer (gestandaardiseerde effectgrootte $d=0,24$ ). Hoewel het totaal aantal glazen per week sterker verminderde dan bij de controlegroep, leidde dat niet significant vaker tot drinken volgens de richtlijn. Het aantal deelnemers dat zich beperkte tot het maximaal aantal glazen zoals beschreven in de richtlijn voor verantwoord drinken was 12 in de interventiegroep (14\%) en 9 in de controlegroep (10\%). De ‘Numbers-needed-to-be-treated’ was 30 (tabel 5.6).

Tabel 5.6: Effectiviteit van Zelfhulpboekje 'Hoe minder te drinken' op risicostatus na 6 maanden ${ }^{a}$.

\begin{tabular}{lccc}
\hline & & $\begin{array}{c}\text { Interventiegroep } \\
(\mathrm{n}=88)\end{array}$ & $\begin{array}{c}\text { Controlegroep } \\
(\mathrm{n}=87)\end{array}$ \\
\hline Behield risicostatus & & 76 & 78 \\
Verloor risicostatus & & 12 & 9 \\
Risico op de stoornis & & 0,86 & 0,90 \\
& & & \\
Risicoverschil (RV) & 0,03 & $95 \% \mathrm{BI}$ & \\
Relatief risico (RR) & 0,96 & $(-0,06 \sim 0,13)$ & \\
NNT & 30 & & \\
\hline
\end{tabular}

$\chi^{2}=0,45, p=0,50$

${ }^{a}$ Risicostatus = iemand drinkt meer dan de gangbare richtlijn voor verantwoord alcoholgebruik (Gezondheidsraad, 2005). Gemeten met: 'Weekly recall, Binge drinken' (Riper et al., in voorbereiding). Voor een uitleg van deze tabel zie tekstblok 2.3 .

De tabel laat zien dat de interventie effect heeft op het reduceren van het alcoholgebruik, maar niet op het beïnvloeden van de risicostatus: het percentage personen dat onder invloed van de interventie het drinkgedrag in overeenstemming brengt met de richtlijn voor verstandig drinken komt niet boven het toeval uit.

\section{Internettest 'De Drinktest'}

De 'Drinktest' (Huiberts \& Boon, 2003a, 2003b) is in een RCT onderzocht, waarbij de interventie werd vergeleken met een digitale voorlichtingsfolder (Boon \& Huiberts, in voorbereiding). De effecten waren positief: een mindering van het aantal drinkdagen en een duidelijker intentie om het alcoholgebruik te minderen. Het percentage overmatige drinkers (drinkt meer dan de richtlijn) daalde na negen maanden 9\% meer in de drinktestgroep dan in de vergelijkingsgroep (tabel 5.7). 
Tabel 5.7: Effectiviteit van 'De Drinktest' op internet op risicostatus na 9 maanden ${ }^{a}$.

\begin{tabular}{|c|c|c|c|c|}
\hline & & & $\begin{array}{l}\text { Interventiegroep } \\
\qquad(\mathrm{n}=102)\end{array}$ & $\begin{array}{c}\text { Controlegroep } \\
(n=89)\end{array}$ \\
\hline Behield risicostatus & & & 71 & 70 \\
\hline Verloor risicostatus & & & 31 & 19 \\
\hline \multirow[t]{2}{*}{ Risico op de stoornis } & & & 0,70 & 0,79 \\
\hline & & $95 \% \mathrm{BI}$ & & \\
\hline Risicoverschil (RV) & 0,09 & $(-0,03 \sim 0,21)$ & & \\
\hline Relatief risico (RR) & 0,89 & $(0,75 \sim 1,05)$ & & \\
\hline NNT & 11 & & & \\
\hline
\end{tabular}

Deze resultaten, voor mannen en vrouwen samen, zijn niet significant. Echter, bij de groep vrouwen nam de risicostatus wél significant af in de interventiegroep (tabel 5.8). Dit effect is ook klinisch relevant. Het gaat hierbij om grote aantallen vrouwen: in 2003 namen 24.625 vrouwen actief deel aan de drinktest. Afgaand op de beschikbare onderzoeksgegevens (persoonlijke communicatie A. Huiberts, NIGZ) ging hiervan 20\% hun drankgebruik zo aanpassen dat ze onder de normatieve grens voor verstandig drinken kwamen. Dat zijn per jaar bijna 5.000 vrouwen die baat hebben gehad van de interventie.

Tabel 5.8: Effectiviteit van 'De Drinktest' op internet op risicostatus van de vrouwelijke deelnemers na 9 maanden ${ }^{a}$.

\begin{tabular}{lccc}
\hline & & $\begin{array}{c}\text { Interventiegroep } \\
(\mathrm{n}=46)\end{array}$ & $\begin{array}{c}\text { Controlegroep } \\
(\mathrm{n}=46)\end{array}$ \\
\hline Behield risicostatus & & 29 & 38 \\
Verloor risicostatus & & 17 & 8 \\
Risico op de stoornis & & 0,63 & 0,83 \\
& & & \\
Risicoverschil (RV) & 0,20 & $(0,02 \sim 0,37)$ & \\
Relatief risico (RR) & 0,76 & $(0,59 \sim 0,99)$ & \\
NNT & 5,1 & & \\
\hline
\end{tabular}

$\chi^{2}=4,45, p=0,03$

${ }^{\text {a }}$ Risicostatus = iemand drinkt meer dan de gangbare richtlijn voor verantwoord alcoholgebruik (Gezondheidsraad, 2005). Gemeten met: 'Weekly recall, Binge drinken' (Riper et al., in voorbereiding ). Voor een uitleg van deze tabel zie tekstblok 2.3.

Het aantal mannen dat de site bezoekt is omvangrijker. In 2003 waren er ruim 63.000 mannen die de test volledig uitvoerden. In potentie kan bij zo'n groep veel gezondheidswinst behaald worden, maar het onderzoek laat bij mannen zulke effecten niet zien. Dit vraagt om verdere aanpassing van de site, of het advies (vooral aan mannen) 
om ook een kijkje te nemen op de site van MinderDrinken.nl, omdat daar een intensievere interventie wordt aangeboden. Er is een nieuwe gerandomiseerde studie gestart die op zulke vragen antwoord kan geven. De uitkomsten van dat onderzoek moeten echter afgewacht worden.

\section{Te behalen gezondheidswinst op bevolkingsniveau}

Alle bovengenoemde geïndiceerde preventieve interventies ter preventie van alcoholmisbruik en -afhankelijkheid zijn geëvalueerd op het terugdringen van de risicostatus, dat wil zeggen of mensen minder gaan drinken dan de gangbare richtlijn voor verantwoord alcoholgebruik (Gezondheidsraad, 2005). Voor deze risicostatus worden in de studie van Van Dijck \& Knibbe (2005) weliswaar prevalentiecijfers voor Nederland genoemd, maar helaas niet de incidentiecijfers die we voor de doorrekening naar bevolkingsniveau nodig hebben.

\subsection{Samenvatting en conclusies preventie van alcoholmisbruik en -afhankelijkheid}

De omvang van alcoholmisbruik en -afhankelijkheid is aanzienlijk: jaarlijks lijden minstens 810.000 mensen in Nederland eraan. Dit is een forse onderschatting, omdat alcoholmisbruik bij jongeren niet is meegeteld. De gevolgen van alcoholmisbruik en -afhankelijkheid zijn groot. De ziektelast van alcoholmisbruik en -afhankelijkheid bedraagt minimaal 141 duizend DALY's, eveneens exclusief de ziektelast van alcoholmisbruik bij jongeren. Ook de zorgkosten zijn aanzienlijk: in totaal ruim 356 miljoen euro. Daarnaast kost het ziekteverzuim als gevolg van alcoholmisbruik en -afhankelijkheid ruim 1 miljard euro per jaar. In 2002 waren minimaal 4.000 mensen met psychische of gedragsstoornissen door alcohol arbeidsongeschikt. Waarschijnlijk zijn dit er veel meer omdat een aantal van hen onder de diagnose depressie als arbeidsongeschikt geregistreerd is. Het KPMG (2001) attendeert bovendien op omvangrijke kosten bij Politie en Justitie. Het aantal nieuwe gevallen van alcoholmisbruik en -afhankelijkheid bedraagt naar schatting zo'n 308 duizend mensen; zij vertegenwoordigen ongeveer 48 duizend DALY's. De zorgkosten voor nieuwe gevallen van alcoholmisbruik en -afhankelijkheid bij volwassenen bedragen jaarlijks bijna 33 miljoen euro; daarnaast genereren deze volwassenen bijna 274 miljoen euro aan productieverliezen door ziekteverzuim. Gezien de grote omvang van alcoholmisbruik en -afhankelijkheid, de hoge jaarlijkse instroom van nieuwe gevallen, en de forse ziektelast waarmee deze stoornis gepaard gaat is het belangrijk om een ruim en gevarieerd interventieaanbod te hebben om alcoholmisbruik en -afhankelijkheid te voorkomen.

\section{Conclusies en aanbevelingen overheidsmaatregelen}

In tegenstelling tot preventie van depressie en angststoornissen zijn bij de preventie van alcoholmisbruik en -afhankelijkheid vooral universele interventies van belang, in het bijzonder overheidsmaatregelen. In het buitenland bewezen effectieve overheidsmaatregelen zijn: accijnsverhoging, beperking van de winkelverkoop van alcohol in het weekend, het verbieden van alcoholreclame en het frequent uitvoeren van onaan- 
gekondigde alcoholcontroles bij automobilisten. Deze zijn in Nederland niet geëvalueerd, maar blijken volgens buitenlands onderzoek aanzienlijke gezondheidseffecten op te leveren. De landelijke overheid heeft al een deel van deze maatregelen ingezet, maar door verdere aanscherping daarvan is wellicht nog meer gezondheidswinst te boeken.

De grote massamediale campagnes hebben vooral effecten op attitudes en kennis. Deze effecten zijn aangetoond in kwalitatief goed onderzoek. Effecten op alcoholgebruik zijn echter (nog) niet aangetoond. Massamediale campagnes hebben op een indirecte manier echter wel gezondheidseffecten. Ze zorgen er immers voor dat jongeren met drankproblemen zich daarvan bewust worden. Vervolgens wijzen ze hen de weg naar andere vormen van preventie die wel aangetoonde gezondheidseffecten hebben.

\section{Conclusies en aanbevelingen preventie van alcoholmisbruik en -afhankelijkheid bij jongeren}

Een veel toegepaste universele interventie voor jongeren is het programma 'De gezonde school en genotmiddelen' (Cuijpers et al., 2002). Een quasi-experimenteel onderzoek liet bescheiden effecten zien op alcoholgebruik. Een grootschalig gerandomiseerd effectonderzoek naar deze interventie is recent gestart. Dit kan meer uitsluitsel bieden over de effectiviteit. In relatie tot de toenemende aandacht voor interventies die de rol van de ouders stimuleren bij het reguleren van het alcoholgebruik van hun kind, wordt in de studie ook bepaald welke combinatie van interventies op scholen, bij scholieren en bij hun ouders het meest effectief is. Bij gebleken meerwaarde kan de ouderinterventie ingebed worden in 'De gezonde school en genotmiddelen'.

Voor jongeren zijn er enkele selectieve interventies, waarbij ondermeer gedacht moet worden aan kinderen van verslaafde ouders. Naast een groepsversie bestaat er ook een interventie die via het internet wordt aangeboden, 'Drankjewel'. Het internet lijkt een goed medium om jongeren te benaderen. Voor volwassenen wordt in Nederland toegewerkt naar een stepped-care aanbod via het internet voor mensen met beginnende tot en met ernstige alcoholproblemen. Het zou aan te bevelen zijn ook zo'n getrapt aanbod op het internet te ontwikkelen voor jongeren. Daarnaast zijn er interventies die specifiek gericht zijn op jongeren in uitgaansgelegenheden. Dit is zeker nodig want jongeren kunnen in uitgaansgelegenheden (te) makkelijk aan alcoholische dranken komen, ook wanneer zij jonger zijn dan de wettelijke minimum leeftijd om alcoholische dranken geschonken te krijgen.

Voor jongeren bestaan nog geen geïndiceerde preventieve interventies. Dit is opvallend, want jongeren vormen de groep met een fors alcoholgebruik, en juist bij hen ontstaat het begin van schadelijk alcoholgebruik. Dit geldt zeker voor de Nederlandse jongeren in verhouding tot hun leeftijdsgenoten in andere landen. Vroegherkenning en vroege interventies zijn bij hen dus bij uitstek gewenst. Inmiddels zijn er op dit gebied enkele initiatieven genomen, waarbij de ouders een belangrijke rol toebedeeld krijgen. Er is momenteel geen zicht op de effectiviteit van deze geplande interventies. Daarvoor is zeker nader onderzoek nodig. 


\section{Conclusies en aanbevelingen preventie van alcoholmisbruik en -afhankelijkheid bij volwassenen en ouderen}

Op het gebied van universele preventie, bestaan er naast de algemene maatregelen van de rijksoverheid, ook enkele massamediale campagnes. De laatste hebben invloed op de kennis en attitude van groepen. Massamediale campagnes kunnen in die zin behulpzaam zijn bij agendasetting van groepen mensen waardoor zij wellicht ook eerder en beter gericht op zoek gaan naar hulp voor alcoholproblemen wanneer dat nodig is. De algemene overheidsmaatregelen vormen zeer waarschijnlijk de meest effectieve en deels ook kosteneffectieve manier om overmatig alcoholgebruik en de daaraan verbonden risico's verder terug te dringen.

Voor volwassenen en ouderen is wel een aanbod van geïndiceerde preventie, maar de meeste interventies zijn nog niet onderzocht op hun effectiviteit. Slechts enkele geindiceerde preventieve interventies voor volwassenen en ouderen zijn geëvalueerd op het terugdringen van de risicostatus, dat wil zeggen of mensen minder gaan drinken dan de gangbare richtlijn voor verantwoord alcoholgebruik (Gezondheidsraad, 2005). Het bestuderen van de effecten op de incidentie van alcoholgerelateerde stoornissen volgens de DSM criteria is geen traditie in alcoholonderzoek, dus dergelijke onderzoeken kunnen nauwelijks verwacht worden. Veel van deze psychologische interventies hebben overigens al wel hun waarde bewezen in de curatieve behandeling van alcoholgerelateerde problemen en stoornissen, zelfs met aantoonbare gunstige effecten op alcoholgerelateerde mortaliteit (Cuijpers et al., 2004).

Van de drie onderzochte interventies zijn er twee effectief gebleken in het terugdringen van de risicostatus: de internetcursus 'Minder drinken' en de internettest 'Drinktest'. Deze laatste is echter alleen effectief bij vrouwen en niet bij mannen. De voorlopige resultaten van een kosteneffectiviteitsanalyse (in voorbereiding) laat zien dat de zelfhulpinterventie 'Minderdrinken' waarschijnlijk ook kosteneffectief is. Momenteel loopt een gerandomiseerd effectonderzoek naar een aangepaste versie van de drinktest. De gecombineerde interventie 'Drinktest' / 'Minder drinken' is in aanzet geschikt voor brede implementatie. Ook kan de 'Drinktest' verder ontwikkeld worden zodat deze ook voor mannen effectief is. Het achterliggend plan is toe te werken naar een online en geïntegreerd stepped-care aanbod. Naar Minderdrinken loopt momenteel een implementatieonderzoek waarbij naast effectiviteit in de praktijk ook gekeken wordt hoe het bereik van dit soort interventies te vergroten is.

\section{Algemene conclusies en aanbevelingen preventie van alcoholmisbruik en -afhankelijkheid}

Het lijkt goed mogelijk om met psychologische interventies drinkgedrag te beïnvloeden. In de curatieve sector blijken psychologische interventies effectief en hebben blijkens een meta-analyse zelfs een aantoonbaar en gunstig effect op alcoholgerelateerde vroegsterfte (Cuijpers et al., 2004). Voor preventieve interventies is het bewijs nog minder sterk of ontbreekt nog. Daar zou meer onderzoek naar gedaan moeten worden. 
Geïndiceerde preventie van alcoholmisbruik en -afhankelijkheid bij volwassenen in Nederland heeft vooral de vorm gekregen van zelfhulp, in boekvorm dan wel via het internet. Juist het internet biedt mogelijkheden om de preventieve interventies aan te passen aan de ernst van de problemen. Zo kunnen mensen die een website bezoeken met een vrij lichte vorm van zelfhulp, terwijl ze een intensievere interventie nodig hebben, verwezen worden naar andere websites waar die intensievere interventies geboden worden. Door het aanbod op deze manier te structureren, krijgen de gecombineerde internet-interventies samen een groter bereik. Deze aanbiedingsvormen op internet gaan met lage kosten gepaard, waardoor ze een grote kans hebben om kosteneffectief te zijn. Hieraan willen we nog toevoegen dat er initiatieven op het gebied van vroegsignalering van alcoholproblematiek zijn ontplooid. Zo is in 2005 het 'Partnership Vroegsignalering Alcohol' gestart in opdracht van VWS. In 2006 presenteert dit Partnership een nationaal actieplan Vroegsignalering Alcohol. Het actieplan voorziet in het identificeren van belangrijke hiaten in het aanbod van kortdurende interventies, attendeert op uitgelezen kansen, en heeft als belangrijkste doel de implementatie van vroegsignalering en geïndiceerde preventie te vergroten. 



\section{OVERZICHT RESULTATEN EN BESCHOUWING}

Zoals vermeld in hoofdstuk 1 is de vraagstelling van dit themarapport als volgt: Welke mogelijkheden zijn er om met preventie het ontstaan van psychische stoornissen te voorkomen, en daarmee de ziektelast en kosten van psychische stoornissen te reduceren?

Deze vraagstelling hebben we in hoofdstuk 2 uitgesplitst in vijf deelvragen.

1. Wanneer lijdt iemand aan een van de geselecteerde psychische stoornissen?

2. Wat zijn op bevolkingsniveau de ernst, omvang en gevolgen van deze psychische stoornissen in Nederland?

3. Welke preventieve interventies zijn in Nederland beschikbaar ter voorkoming van deze psychische stoornissen?

4. Is het mogelijk om met dergelijke interventies bij de individuele deelnemers het ontstaan van deze stoornissen te voorkomen?

5. Is het mogelijk de gezondheidswinst als gevolg van preventie door te rekenen naar omvang, ernst en gevolgen op bevolkingsniveau?

In de voorgaande drie hoofdstukken hebben we deze deelvragen beantwoord voor respectievelijk depressie (hoofdstuk 3), angststoornissen (4) en alcoholmisbruik en -afhankelijkheid (5). In de slotparagrafen van deze hoofdstukken hebben we de conclusies per stoornisgroep beschreven. In paragraaf 6.1 bespreken we de consequenties van de gekozen onderzoeksopzet voor de gevonden resultaten. Vervolgens plaatsen we in paragraaf 6.2 de conclusies van de voorgaande hoofdstukken in onderling verband. In paragraaf 6.3 stellen we de vraag of de in dit rapport beschreven preventieve interventies zouden kunnen leiden tot onnodige medicalisering van alledaags psychisch leed. In $p a-$ ragraaf 6.4 gaan we in op het belangrijkste knelpunt: het geringe bereik van de preventieve interventies. De beleidsmatige en organisatorische aanbevelingen om dit bereik te verhogen staan beschreven in hoofdstuk 7.

In tekstblok 6.1 bespreken we ter illustratie de mogelijkheden voor de preventie van schizofrenie. Omdat schizofrenie een vrij zeldzame ziekte is en de preventieve mogelijkheden vooralsnog beperkt zijn, is aan de preventie van schizofrenie niet een heel hoofdstuk gewijd.

\subsection{Consequenties van de methodologische uitgangspunten}

In dit rapport hebben we ons expliciet beperkt tot preventieve interventies waarvan het effect op de gezondheid bekend is. In de eerste instantie hebben we ons gericht op interventies die zijn onderzocht op het voorkómen van de psychische stoornis. Waar dergelijke studies ontbraken, hebben we ons gericht op andere gezondheidsmaten: verandering in risicostatus of verandering in stoornisspecifieke klachten. Het is aan- 
nemelijk dat een afname van klachten (al dan niet tot onder het niveau van de risicostatus) ook zal leiden tot het voorkómen van de stoornis, maar we kunnen dit niet met zekerheid aantonen.

Voor de definitie van depressie, angststoornissen en alcoholmisbruik en -afhankelijkheid hebben we de criteria gehanteerd zoals ze staan omschreven in het psychiatrische handboek: de DSM-IV. Hierdoor vonden we aansluiting bij de binnen- en buitenlandse wetenschappelijke literatuur over epidemiologie en behandeling, die immers grotendeels gebaseerd is op deze diagnostische classificatie. Door DSM-criteria te gebruiken voor de specifieke stoornissen, konden de effecten op incidentie doorgerekend worden naar bevolkingsniveau. Daardoor kon het gezondheidseffect ook worden uitgedrukt in bevolkingsmaten als ziektelast en euro's.

Bij het beoordelen van de wetenschappelijke evidentie voor de effectiviteit van de preventieve interventies, sluiten we aan bij de gangbare wijze van rapporteren over de effecten van behandeling in de multidisciplinaire richtlijnen voor de GGZ. Deze strenge criteria zijn gebaseerd op de 'evidence-based medicine' (Offringa et al., 2003). We keken bijvoorbeeld vooral naar gerandomiseerd onderzoek, randomised clinical trials (RCT's), waardoor we vrij harde wetenschappelijke uitspraken kunnen doen over de werkelijke effectiviteit van de interventies (Schoemaker et al., 2006). Dankzij RCT’s is het mogelijk om het werkelijke effect van interventies te beoordelen, los van het natuurlijk beloop.

Door ons uitsluitend te richten op de gezondheidseffecten van preventie lieten we andere effecten van preventieve interventies buiten beschouwing. Dat betekent allereerst dat onderzoeken met alleen procesdoelen (bijvoorbeeld het bereik en de kwaliteit van de interventie, of de tevredenheid van de deelnemers met de interventie) als uitkomstmaat vrijwel niet zijn beschreven. Daarnaast hebben interventies die zich niet direct richten op gezondheidseffecten, maar op het vergroten van kennis of het veranderen van de attitude, een beperkte wetenschappelijke status toebedeeld gekregen. Zie bijvoorbeeld de grote massamediale campagnes rond alcohol, waarvan de effecten overtuigend zijn aangetoond in kwalitatief goed onderzoek. Omdat effecten op alcoholgebruik (nog) niet zijn aangetoond, is de wetenschappelijke status van deze interventies in dit rapport beperkt.

Door het ontstaan van specifieke klachten en stoornissen als effectmaten te kiezen, bleven ook preventieve maatregelen buiten het directe terrein van volksgezondheid onderbelicht. Dat zijn bijvoorbeeld beleidsmaatregelen buiten de strikte gezondheidssfeer, maar waarbij toch sprake is van het voorkómen van gezondheidsschade en/of het bevorderen van gezondheid. Dit wordt ook wel integraal gezondheidsbeleid genoemd (tekstblok 7.1). Als dergelijke beleidsmaatregelen al op hun effect zijn onderzocht, dan gebeurde dat op vrij algemene effectmaten, zoals sociaal en psychisch welbevinden. Het effect op het ontstaan van stoornissen of op stoornisspecifieke klachten werd niet gemeten. Een uitzondering vormt de aanpak bij alcoholpreventie. Daar zijn preventieve maatregelen effectief gebleken, zoals accijnsverhoging, verkeerscontroles, beperking van de winkel- 
verkoop van alcohol in weekend en verbieden van reclame voor alcoholische dranken (paragraaf 5.3).

Hoewel het effect van integraal gezondheidsbeleid op het ontstaan van psychische stoornissen (nog) nauwelijks wetenschappelijk is aangetoond, is het aannemelijk dat dergelijke maatregelen een positief effect hebben op de geestelijke volksgezondheid, en mogelijk indirect op het ontstaan van psychische stoornissen. Daarnaast kunnen dergelijke maatregelen een beleidsmatig kader bieden voor de uitvoering van de in dit rapport beschreven afzonderlijke interventies. Op welke wijze de landelijke overheid en gemeenten dit soort beleid zouden kunnen uitvoeren, komt aan de orde in hoofdstuk 7.

Een belangrijke beperking van de gekozen onderzoeksopzet is dat de beschreven interventies en de aangehaalde onderzoeken zich richten op de effecten op het ontstaan van één stoornis. Daaruit zou de indruk gewekt kunnen worden dat psychische stoornissen als depressie, angst en alcohol elkaar uitsluiten. Die indruk is onterecht. Comorbiditeit - het samen voorkomen van meer dan één stoornis in een bepaalde tijdsperiode - is bij psychische stoornissen eerder regel dan uitzondering. Bijna de helft van de mensen met een geschiedenis van ten minste één psychische stoornis had ooit ook één of meer andere psychische stoornissen (Vollebergh et al., 2003).

Comorbiditeit heeft belangrijke gezondheidseffecten: zo hangt ze samen met ernstiger klachten en een langere duur van de stoornis. Mensen die lijden aan meerdere stoornissen tegelijk maken ook meer gebruik van de gezondheidszorg dan mensen met maar één stoornis (Bijl \& Ravelli, 2000). We zouden ook een verkeerde indruk gewekt hebben wanneer gedacht wordt dat een preventieve interventie voor één stoornis alleen maar effecten heeft voor die ene stoornis. Voor zover onderzocht, zien we juist dat een preventieve interventie meestal effecten heeft in een heel spectrum van stoornissen. Dit zou ondermeer betekenen dat de gezondheidseffecten van preventieve interventies meer omvattend zijn dan uit onze rapportage blijkt.

Voor de preventie van psychische stoornissen heeft comborbiditeit - en met name die tussen angst-en stemmingsstoornissen - belangrijke consequenties. Soms is het mogelijk om met één interventie meerdere stoornissen tegelijkertijd aan te pakken. Een voorbeeld daarvan is 'Alles onder controle' (paragraaf 3.4.1). In tekstblok 7.1 worden interventies beschreven gericht op stresspreventie op het werk; deze interventies zijn ook bedoeld voor het voorkomen van meerdere stoornissen. Vaak is het echter nodig zo'n interventie focaal, d.w.z. op één probleem gericht, uit te voeren. Daarna kan bezien worden of de andere problemen nog steeds aandacht behoeven, of inmiddels ook opgelost zijn. Maar er zijn ook andere mogelijkheden. Voor de combinatie angst- en stemmingsstoornissen geldt bijvoorbeeld dat de angststoornis meestal vooraf gaat aan de stemmingsstoornis. Een vroege interventie gericht op een angststoornis kan dan mogelijk ook helpen een comorbide depressie te vermijden. De pilotstudie van de ‘Geen paniek' interventie wees op zo'n effect (zie paragraaf 4.4.1). 
In het rapport richten we ons zoals gezegd voornamelijk op het voorkomen van het ontstaan van stoornissen. Omdat bijvoorbeeld depressie in veel gevallen een chronisch beloop kent, is het ook van belang om te voorkomen dat de stoornis na afloop van de behandeling weer terugkomt. Dergelijke maatregelen worden 'terugvalpreventie' genoemd. Deze maatregelen bleven buiten beeld, omdat we ons richtten op primaire preventie: het voorkomen van het ontstaan van nieuwe stoornissen. Daarmee willen we het belang van terugvalpreventie niet onderschatten. Verschillende onderzoekers hebben laten zien dat terugvalpreventie een zeer kosteneffectieve manier is om het langetermijneffect van behandeling depressie te vergroten (Scott et al., 2003).

In dit rapport is de RCT gepresenteerd als de ideale vorm van onderzoek, omdat zo het beste de effectiviteit kan worden bepaald. Deze keuze heeft echter ook zijn keerzijde. Zo lenen veel preventieve interventies zich niet voor een RCT. Sommige - vooral community based - interventies bestaan uit meerdere onderdelen, en zijn om die reden heel moeilijk te onderzoeken in de vorm van een RCT. Ook de effectiviteit van allerlei beleidsmaatregelen die indirect invloed zouden kunnen hebben op het aantal nieuwe gevallen van de onderscheiden stoornissen blijft onbekend. Dit wil dus niet zeggen dat deze interventies niet effectief zijn.

De maximale follow-up van één jaar in het onderzoek heeft een belangrijke consequentie voor de reikwijdte van de conclusies. Het is immers mogelijk dat de met een preventieve interventie voorkomen gevallen van depressie niet de hele zware en recidiverende gevallen zouden zijn geworden. Om dat te weten zouden onderzoeken een veel langere followup, van vijf of tien jaar, moeten krijgen. Op die manier kan dan ook worden onderzocht of de effecten van de interventies langer aanhouden dan één jaar. Het is nu nog niet uit te sluiten dat de preventieve interventies slechts uitstel van het ontstaan van een stoornis betekenen. Er worden dan gezonde levensjaren gewonnen, maar de persoon heeft geen garantie dat de stoornis niet alsnog ontstaat op een later moment.

De modelmatige doorrekeningen naar aantallen personen, DALY's en kosten kennen twee belangrijke beperkingen. Allereerst zijn ze gebaseerd op een groot aantal aannames (bijlage 6). Het is wetenschappelijk veel mooier om de kosteneffectiviteit en de effecten op de ziektelast direct te meten in de RCT's zelf. Dit gebeurt de laatste jaren gelukkig steeds vaker. Ten tweede zijn de doorrekeningen noodgedwongen gebaseerd op gedateerde epidemiologische cijfers over psychische stoornissen. Nieuw grootschalig epidemiologisch onderzoek naar prevalentie én incidentie van psychische stoornissen is dringend noodzakelijk.

\subsection{Preventie voorkomt het ontstaan van psychische stoornissen}

Depressie, angststoornissen en alcoholmisbruik en -afhankelijkheid komen veel voor: jaarlijks lijden één op de vijf mensen in Nederland aan een van deze stoornissen. Ze komen niet alleen veel voor, maar leggen ook aanzienlijke beperkingen op aan het 
functioneren: ze behoren alle drie tot de top 10 van ziekten met de grootste ziektelast. Ook als het gaat om zorgkosten scoren psychische stoornissen hoog: zo kost de zorg voor depressie jaarlijks bijna 700 miljoen euro. Ziekteverzuim en arbeidsongeschiktheid als gevolg van psychische klachten zijn omvangrijk: één op de drie arbeidsongeschikten kan niet werken om psychische redenen. Ook dat leidt tot hoge jaarlijkse kosten.

De geestelijke gezondheidszorg (GGZ) beschikt over effectieve behandelingen van de genoemde stoornissen. Toch lukt het maar heel gedeeltelijk de ziektelast op populatieniveau te verminderen. De reden is dat niet iedereen met een diagnose wordt bereikt, vervolgens niet iedereen een bewezen effectieve behandeling krijgt, of de ontvangen behandeling even trouw volgt. Maar zelfs onder de meest optimale omstandigheden kan de ziektelast door curatie met maximaal $40 \%$ verminderd worden. Met andere woorden, de ziektelast van psychische stoornissen blijft voor $60 \%$ voortbestaan. Dit pleit er voor om naast behandeling ook preventie aan te bieden, om zo de ziektelast nog verder terug te dringen. Daarbij heeft het voorkómen van psychische stoornissen, als dat mogelijk is, uiteraard de voorkeur boven het behandelen van al bestaande stoornissen.

\section{Tekstblok 6.1: Preventie van schizofrenie.}

Schizofrenie is een complex ziektebeeld, met een grote variatie aan positieve en negatieve symptomen. Positieve symptomen zijn ongewone verschijnselen als wanen of hallucinaties. Negatieve symptomen bestaan uit het ontbreken van gedragingen of belevingen die er normaal wel zijn. Voorbeelden zijn: affectieve vervlakking, sociaal terugtrekgedrag, apathie, initiatiefverlies en spraakarmoede. Er zijn mensen met overwegend wanen en/of hallucinaties en anderen met overwegend negatieve symptomen. Daarnaast zijn er stoornissen in cognitieve vaardigheden als geheugen, concentratie en uitvoering van ingewikkelde taken. Daardoor functioneren mensen met schizofrenie sociaal en beroepsmatig vaak slecht (Schoemaker et al., 2002).

Hoewel het aantal personen met schizofrenie in verhouding tot de in dit rapport beschreven stoornissen vrij gering is, ongeveer 23 duizend mensen, is de ziektelast zeer omvangrijk: schizofrenie is één van de meest invaliderende psychische stoornissen. Schizofrenie heeft naar schatting een ziektelast van bijna 14 duizend DALY's in Nederland (Hoeymans et al., 2006). Omdat in verhouding veel mensen met schizofrenie worden opgenomen, zijn de zorgkosten van schizofrenie toch vrij hoog.
Volgens de Multidisciplinaire richtlijn schizofrenie (2005) is universele preventie van schizofrenie niet mogelijk. In Nederland bestaat voor de overige preventievormen nog geen standaardpraktijk voor schizofrenie. In de internationale literatuur wordt al wel gespeculeerd over mogelijkheden voor geïndiceerde preventie van schizofrenie. Schizofrenie wordt in de meeste gevallen namelijk voorafgegaan door een periode van voortekenen, de prodromale fase. Geïndiceerde preventie van schizofrenie probeert te voorkomen dat deze voorfase van schizofrenie overgaat in een echte stoornis. In het buitenland zijn inmiddels enkele effectstudies verricht.

\section{Buitenlands onderzoek naar het effect van geïn- diceerde preventie}

Geïndiceerde preventieve interventies, vooral interventies van gedragstherapeutische signatuur, kunnen bij geselecteerde hoog-risicogroepen van jongeren en jongvolwassenen de overgang naar een psychotische stoornis helpen voorkomen of uitstellen. Het bewijs hiervoor komt uit enkele kleine buitenlandse studies. De hoog-risicogroepen uit deze studies werden samengesteld op basis van de volgende factoren: de aanwezigheid van subklinische psychotische symptomen, of voorbijgaande psychotische symptomen, of een familiegeschiedenis van schizofrenie in combinatie met een significante achteruitgang in het functioneren (McGorry et al., 2003; Phillips et al., 2005). 
- Specifieke preventieve interventie: McGorry et al. (2002) bestudeerden in Australië een, wat zij noemen, 'specifieke preventieve interventie' (SPI) om een psychose te voorkomen. De interventie bestond uit antipsychotische medicatie (risperidon), cognitieve gedragstherapie en casemanagement met op de actuele problemen en behoeften gebaseerde psychotherapie. De onderzoekers vonden een kortetermijn effect: het aantal mensen dat binnen 6 maanden na de interventie een psychose doormaakte was significant lager in de interventiegroep dan in de controlegroep. Op langere termijn verdween dit effect echter.

- Preventie met olanzapine: Woods et al. (2003) vergeleken in de VS de preventieve werking van het antipsychoticum olanzapine met een placebo bij een steekproef van 60 personen in de leeftijd van 12 tot 45 jaar met prodromale kenmerken van een naderde psychose. $\mathrm{Na}$ acht weken had de experimentele groep weliswaar iets minder prodromale symptomen, maar de effecten waren niet significant.

- Cognitieve gedragstherapie: In Engeland onderzochten Morrison et al. (2004) de meerwaarde van een cognitieve gedragstherapie boven monitoring bij 58 patiënten in de leeftijd van 16 tot 36 jaar. De therapie sloot aan bij de stoornis die naar het gezamenlijk oordeel van therapeut en patiënt de meeste aandacht verdiende.

Dit kon een psychose zijn, maar ook angst of depressie. Na één jaar had $6 \%$ van de interventiegroep een psychotische stoornis ontwikkeld, tegen $26 \%$ in de controlegroep. De effecten waren weliswaar statistisch significant, maar dit was gedeeltelijk te danken aan methodologische onvolkomenheden van het experiment
(2 personen uit de interventiegroep bleken bij aanvang van het experiment al een psychose te hebben, en werden achteraf teruggetrokken uit het experiment).

\section{Internationale preventierichtlijn}

De International Early Psychosis Association Writing Group (2005) ontwikkelde een richtlijn voor preventieve interventies bij jongeren met een zeer hoog risico op een psychose. Antipsychotische medicatie als preventief middel wordt daarin afgeraden. De toepassing van antipsychotische medicatie als preventieve interventie is op dit moment nog controversieel (Mason \& Beavon-Pearson, 2005; Morrison et al., 2004) omdat er ook risico's aan verbonden zijn. De andere preventievormen - cognitieve gedragstherapie en SPI - worden als voorlopig effectief beschouwd, hoewel de baten en risico's nog nader moeten worden onderzocht (Marlowe, 2004; Warner, 2005).

De aanpak in Nederland sluit grotendeels aan bij deze internationale richtlijn. Er is in Nederland echter meer discussie over de vraag of een actief programma moet worden opgezet om personen met een hoog risico op te sporen. In Amsterdam is men hier wel mee bezig (Linszen, persoonlijke mededeling november 2005). In Maastricht zet men vooral in op een zo groot mogelijke toegankelijkheid van het aanbod, zodat de hoog-risico groep de filters naar de geestelijke gezondheidszorg soepel passeert (Van Os \& Delespaul, 2005). Parnassia is in samenwerking met de Vrije Universiteit bezig een preventietrial op te zetten om te bezien in hoeverre het mogelijk is om bij hoogrisicogroepen het ontstaan van een psychose te voorkomen dan wel uit te stellen (Van der Gaag, persoonlijke mededeling oktober, 2006).

Preventie van psychische stoornissen is lang een gebied geweest waar goede bedoelingen de boventoon voerden. Dit terrein is de laatste jaren echter sterk aan het professionaliseren en verwetenschappelijken. Het aantal kwalitatief goede effectonderzoeken groeit gestaag. Dit rapport zet een groot aantal onderzoeken op het gebied van preventie van depressie, schadelijk alcoholgebruik en angststoornissen op een rij. Daaruit komt naar voren dat er nu voldoende bewijs is om bepaalde preventieve interventies op grotere schaal toe te passen. Er is preventief veel meer mogelijk dan een aantal jaren geleden.

De doelgroepen voor preventieve interventies bevinden zich op een continuüm tussen gezond en ziek. Universele preventie richt zich met voorlichting op gezonde mensen, selectieve preventie richt zich op mensen met een verhoogd risico (zoals kinderen van ouders met psychische stoornissen) en geïndiceerde preventie is bedoeld voor mensen met beginnende klachten, die echter (nog) niet beantwoorden aan de officiële 
diagnose voor een psychische stoornis. Van een aantal geïndiceerde preventieve interventies is inmiddels bekend dat ze het ontstaan van psychische stoornissen kunnen voorkomen.

Uit de voorgaande hoofdstukken blijkt dat het daadwerkelijk mogelijk is om met preventieve interventies te voorkomen dat mensen met beginnende depressiviteitsklachten een echte depressie ontwikkelen. Voorbeeld is de cursus 'In de put, uit de put', die wordt aangeboden als groepscursus en als individuele zelfhulpcursus met minimale begeleiding. Ook blijken bepaalde overheidsmaatregelen effectief te zijn in het terugdringen van schadelijk alcoholgebruik: accijnsverhoging, beperking van de winkelverkoop van alcohol in het weekend, het verbieden van alcoholreclame en onaangekondigde alcoholcontroles bij automobilisten. Voor het terugdringen van schadelijk alcoholgebruik bij volwassenen zijn effectieve geïndiceerde interventies beschikbaar via internet: bij voorbeeld de cursus 'Minder drinken' en de 'Drinktest'. Tot slot is er erg weinig bekend over de effectiviteit van preventieve interventies voor angststoornissen. Deze achterstand is opvallend, omdat het aantal mensen met angststoornissen groter is dan dat van depressie, en de ziektelast van bepaalde angststoornissen die van depressie ten minste evenaart.

Er wordt echter nog niet zo heel lang gerandomiseerd effectonderzoek gedaan naar de preventie van psychische stoornissen. Over de hele wereld is tot nu toe slechts een handvol gerandomiseerde studies gedaan waarin het effect op incidentie is onderzocht (Cuijpers et al., 2005). Meer (kosten-)effectiviteitsonderzoek is hard nodig. Enkele in het buitenland effectief gebleken interventies zijn nog niet in Nederland geïmplementeerd en op hun effectiviteit getoetst. Op dit moment loopt een aantal van dat soort onderzoeken. Ook zouden bestaande werkzame interventies geschikt moeten worden gemaakt voor internet, en op hun (kosten-) effectiviteit getoetst. Nieuwe preventieve interventies zouden moeten worden ontwikkeld waarin rekening wordt gehouden met de comorbiditeit tussen depressie, angststoornissen en alcoholproblemen. Tot slot zijn er interventies die al worden aangeboden in Nederland maar nog nooit onderzocht zijn op hun effectiviteit. Dat zou moeten gebeuren, bij voorkeur in een RCT en nog liever in twee RCT's, om de bewijskracht van de conclusies te verhogen. Aan dat effectonderzoek van bestaande interventies zouden ook consequenties moeten worden verbonden. Als blijkt dat interventies niet werken, kan men de arbeidskracht en het geld beter steken in interventies die dat wel doen.

\subsection{Gevaar van medicalisering van alledaags leed?}

De belangrijkste aanbevelingen van dit rapport zijn gericht op het verhogen van het bereik van preventieve interventies voor psychische stoornissen, en dan vooral depressie en alcoholgerelateerde stoornissen zoals alcoholmisbruik en alcoholafhankelijkheid, in de zin van de DSM. Zoals we hebben laten zien, hebben die interventies naar verwachting positieve effecten op de gezondheid van de deelnemers, en vermindert het hun kans op een psychische stoornis. Bij een voldoende groot bereik kan dit op bevolkingsniveau gezondheidseffecten hebben. 
Critici van deze aanpak zouden kunnen tegenwerpen dat met het op grote schaal aanbieden van preventieve interventies sprake is van het medicaliseren van alledaags leed. Andere termen die in dit verband wel worden gebruikt zijn therapeutisering en psychologisering. Als mensen met lichte depressiviteitsklachten deelnemen aan een groepscursus, zouden ze leren hun eigen dagelijks problemen te psychologiseren, en los te zien van de context. Daarbij zouden ze zich afhankelijk maken van hulpverleners, waardoor ze wellicht minder verantwoordelijkheid nemen voor hun eigen leven. Tot slot zou het kunnen leiden tot een vergrote toeloop op de GGZ, die zonder deze aanzuigende werking al kampt met wachtlijsten. Vóór we in paragraaf 6.4 en hoofdstuk 7 aanbevelingen doen over maatregelen om het bereik te verhogen willen we eerst ingaan op deze vragen.

Of preventieve interventies leiden tot het onnodig psychologiseren van alledaagse problemen, en daarmee het individualiseren van maatschappelijke leed, hangt allereerst af van de inhoud van de interventies. De meeste interventies zijn gebaseerd op bestaande therapievormen zoals probleemoplossingstherapie en cognitieve gedragstherapie (tekstblok 2.2). Deze worden bij preventieve interventies aangeboden in een psycho-educatief format, wat betekent dat deelnemers vaardigheden leren die zij zelf op hun leven kunnen toepassen. Daarbij wordt niet gegraven in het verleden, maar blijft men concreet in het heden. Deze interventies richten zich op het gedrag, de gedachten en de gevoelens in het heden. De dagelijkse problemen waar iemand tegenaan loopt, staan daarbij centraal. Daarbij houdt de deelnemer zelf de verantwoordelijkheid voor het eigen leven. Sterker nog: door de cursus leert hij weerbaarder te worden, wat op een praktische manier helpt om met dagelijkse verantwoordelijkheid beter om te gaan. Veel deelnemers melden dergelijke 'empowerment' effecten bij de evaluatie van cursussen.

Preventieve interventies kunnen daarnaast sommige vormen van medicalisering zelfs helpen voorkomen. Zo krijgen op dit moment veel mensen met klachten zonder dat sprake is van een echte depressieve stoornis of angststoornis door hun huisarts antidepressiva of anxiolitica (benzodiazepinen) voorgeschreven. Waarschijnlijk gaat het om grote groepen mensen. Voor deze lichtere subklinische depressie is het voorschrijven van antidepressiva niet evidence-based; uit onderzoek blijkt dat het voor deze lichte klachten niet beter werkt dan placebo. Anders gezegd: er is sprake van onnodige medicalisering. Door deze mensen geen antidepressiva meer voor te schrijven, maar ze te verwijzen naar een preventieve interventie die wel werkt, kunnen huisartsen onnodige medicalisering juist voorkomen. Dit wordt herkend als een expliciet doel van een van de doorbraakprojecten in de huisartsgeneeskunde voor depressie (Franx et al., 2006b).

Tot slot de aanzuigende werking. Er bestaat een enorme drempel om hulp te zoeken voor psychische problemen; daar rust een taboe op. Preventieve interventies zoals cursussen en zelfhulpboeken hebben een lagere drempel. Mogelijk dat mensen die na afloop van de cursus toch nog depressief worden - en dat gebeurt bij zo'n $20 \%$ - dankzij de cursus de weg hebben gevonden in de GGZ. Er zijn geen signalen uit de praktijk dat dit inderdaad leidt tot een toename van aanmeldingen bij de GGZ, maar wanneer het bereik van preventie aanzienlijk wordt vergroot dan is een dergelijke ontwikkeling 
niet uit te sluiten. Omdat de inhoud van de preventieve interventies doorgaans een vereenvoudigde versie is van reguliere psychologische behandelingen ligt het voor de hand dat deze mensen ook sneller behandeld kunnen worden. Verder verwachten we dat de mensen die zich bij de GGZ melden dat op een vroeg tijdstip doen (in de cursus hebben zij immers kennis opgedaan over de betreffende aandoening en weten wanneer professionele hulp aangewezen is), waardoor met vroege interventies escalatie van de problemen voorkomen kan worden.

\subsection{Geringe bereik van preventie belangrijkste knelpunt}

Het belangrijkste knelpunt in de praktijk is op dit moment het geringe bereik van vooral de geïndiceerde preventieve interventies: zo worden met depressiepreventie slechts ongeveer vierduizend mensen per jaar bereikt. Dat is slechts $1 \%$ van de ruim 350 duizend mensen die jaarlijks depressie ontwikkelen. Om de ziektelast werkelijk te verminderen, zou het aantal deelnemers aan de effectief gebleken interventies flink omhoog moeten. Maatregelen zouden zich daarom vooral moeten richten op uitbreiding van het aanbod van effectieve interventies en verhoging van het aantal bereikte mensen uit de doelgroepen. In deze paragraaf beperken we ons tot mogelijke inhoudelijke verbeteringen die kunnen leiden tot verhoging van het bereik. Beleidsmatige aanbevelingen over wetgeving, financiering en samenwerking tussen partijen komen aan de orde in hoofdstuk 7.

Voor zover er cijfers bekend zijn over het bereik van de doelgroepen, lijkt het erop dat bepaalde bevolkingsgroepen in verhouding minder worden bereikt: bijvoorbeeld allochtonen en lager opgeleiden. Dit geldt met name voor mensen die te maken hebben met een combinatie van risicofactoren, zoals ouderen of mensen met een lage sociaal-economische status. Tot de laatste groep behoren vaak ook allochtonen. Steeds meer interventies worden speciaal voor deze groepen ontwikkeld. Mogelijk zijn zij ook beter te bereiken met preventieve interventies waarbij de nadruk minder ligt op praten, en bij voorbeeld meer op bewegen - dat laatste heeft namelijk gunstige effecten op zowel angst- als stemmingsstoornissen (Arent \& Landers, 1999; Arent, 2000; Callaghan, 2004; Fox, 1999; Jorm et al., 2002; Petruzzelo et al., 1991). Meer bewegen wordt in de nieuwe preventienota 'Kiezen voor gezond leven' overigens ook genoemd in het kader van gezonder leven, bestrijding van overgewicht en diabetes (VWS, 2006d). Het is een mooi voorbeeld van een interventie die gunstige effecten heeft in een breed spectrum van gezondheid en ziekte.

Aparte aandacht verdient onderzoek naar hoogrisicogroepen. Preventieve interventies worden vaak aangeboden aan mensen met beginnende klachten. Deze groep heeft namelijk een verhoogd risico om een stoornis te krijgen. Het risico op de stoornis in de groep met beginnende klachten is echter variabel: bij een aantal van deze mensen zal geen stoornis ontstaan. Om medisch-ethische en economische redenen zou men daarom preventie wellicht nog verder willen toespitsen, en zich bijvoorkeur richten op groepen met een berekenbaar ultra-hoog risico. Dit zijn groepen die niet alleen beginnende symptomen hebbenvan debetreffendestoornis, maar diebovendien worden gekenmerkt 
door een aantal andere sterke voorspellers voor het ontstaan van de betreffende stoornis. Bij depressie op latere leeftijd gaat het bijvoorbeeld om recent weduwschap, geringe zelfwaardering, een zware lichamelijke ziekte en een lage opleiding (Schoevers et al., 2006, Smit et al., 2006a). Bij angststoornissen op de latere leeftijd gaat het om vergelijkbare risicofactoren (Smit et al., in druk-a). Het lijkt waarschijnlijk dat preventie gericht op zulke hoogrisicogroepen kosteneffectief zal worden: de betreffende doelgroep is immers klein in aantal en toch verantwoordelijk voor een aanzienlijk deel van de toekomstige nieuwe gevallen van de betreffende stoornis. Het onderzoek naar de optimale samenstelling van deze hoogrisicogroepen is echter nog maar net begonnen, en preventie-trials dienen eerst nog aan te tonen hoe kosteneffectief interventies in deze hoogrisicogroepen werkelijk zijn. In toekomstig effectonderzoek zou meer aandacht moeten komen voor deze hoogrisicogroepen. In hoeverre deze hoogrisicogroepen al zijn vertegenwoordigd in de beschreven onderzoeken in dit rapport, is onbekend.

Sommige risicofactoren zijn niet of nauwelijks te beïnvloeden met een individugerichte aanpak, zoals slechte sociale en fysieke omstandigheden. Hiertoe behoren bijvoorbeeld omstandigheden die te maken hebben met huisvesting, veiligheid of de kwaliteit van de buurt waarin iemand woont. Individugerichte preventieve interventies kunnen helpen om de zelfredzaamheid van de betrokkene te vergroten, maar er zijn daarnaast structurele maatregelen nodig om de fysieke omstandigheden daadwerkelijk te verbeteren. Dergelijke risicofactoren kunnen een aangrijpingspunt zijn voor integraal gezondheidsbeleid. Hier gaan we in paragraaf 7.2 verder op in. 


\section{ORGANISATORISCHE CONTEXT EN BELEIDSAANBEVELINGEN}

\subsection{Inleiding}

De hoofdstukken 3 tot en met 6 van dit themarapport hebben laten zien dat het aanbod aan preventieprogramma's groot is. Het belangrijkste knelpunt is op dit moment het geringe bereik van dergelijke interventies. Zo wordt met depressiepreventie jaarlijks ongeveer vierduizend mensen bereikt. Dat is slechts 1\% van de ruim 350 duizend mensen die per jaar een depressie ontwikkelen. In de slotparagraaf van hoofdstuk 6 is besproken hoe op het niveau van de interventies zelf gewerkt kan worden aan manieren om het bereik te verhogen. Het aanbod en bereik van interventies voor de preventie van psychische stoornissen wordt echter ook voor een groot deel bepaald door de organisatorische en beleidsmatige context. Deze context biedt de randvoorwaarden waarbinnen preventie van psychische stoornissen mogelijk is. Door de randvoorwaarden te verbeteren kan het aanbod en bereik van preventieve interventies vergroot worden, vooral van geïndiceerde preventie.

In paragraaf 7.2 worden de organisatorische en beleidsmatige context voor de preventie van psychische stoornissen beschreven. Deze blijken complex en versnipperd. Dat geldt niet alleen voor de actoren, maar ook voor de verantwoordelijkheden, financiering en wetgeving. Om het aanbod en bereik van geïndiceerde preventie te vergroten, zou preventie van psychische stoornissen goed verankerd moeten worden in zowel het gemeentelijk beleid als in de gezondheidszorg. Daarnaast zou de landelijke overheid erop moeten toezien dat deze deelterreinen op elkaar kunnen aansluiten.

In de paragrafen 7.3 tot en met 7.5 bespreken we concrete aanbevelingen voor de beleidsmatige en organisatorische verankering van de preventie van psychische stoornissen op elk van deze beleidsterreinen: het landelijke preventiebeleid (paragraaf 7.3), het gemeentelijke preventiebeleid (7.4) en de gezondheidszorg (7.5).

\subsection{Organisatorische en beleidsmatige context}

Deze paragraaf geeft een korte schets op hoofdlijnen van de organisatorische en beleidsmatige context van preventie van psychische stoornissen. Voor de uitgebreidere beschrijvingen verwijzen we naar twee bijlagen. Aan bod komen achtereenvolgens de settings voor de preventie van psychische stoornissen (paragraaf 7.2.1; bijlage 8), de belangrijkste wettelijke kaders en financiering van preventie van psychische stoornissen (paragraaf 7.2.2) en de plaats van de preventie van psychische stoornissen in beleidsnota's door de jaren heen (paragraaf 7.2.3; bijlage 7). De paragraaf wordt afgesloten met conclusies (paragraaf 7.2.4). 


\subsubsection{Preventie van psychische stoornissen binnen de gezondheidszorg}

Preventieve interventies gericht op psychische stoornissen worden op zeer verschillende plaatsen aangeboden, door verschillende instanties. De in dit themarapport beschreven vormen van preventie van psychische stoornissen - universeel, selectief en geïndiceerd - kunnen globaal in vier verschillende deelterreinen worden geplaatst: settings buiten de gezondheidszorg (bijvoorbeeld scholen, werk; tekstblok 7.1), de openbare gezondheidszorg (GGD-en), de eerstelijns gezondheidszorg (huisarts, bedrijfsarts, algemeen maatschappelijk werk, thuiszorg) en tot slot de tweedelijns gezondheidszorg (GGZ-instellingen inclusief instellingen voor de verslavingszorg, ziekenhuizen, verpleeghuizen). De settings buiten de gezondheidszorg en de openbare gezondheidszorg vormen samen de nuldelijn (Boot \& Knapen, 1986).

Per regio wordt samengewerkt in steeds wisselende combinaties van actoren, waarbij sommige actoren meerdere rollen kunnen spelen. Zo zijn de GGZ-preventie afdelingen

\section{Tekstblok 7.1: Integrale preventie van psychische belasting op de werkplek.}

Omdat psychische stoornissen een belangrijke bron zijn van ziekteverzuim, ligt het voor de hand om ook op de werkplek preventieve interventies aan te bieden. Deze interventies richten zich over het algemeen op het verminderen van werkstress. Aangenomen wordt dat dit een belangrijke factor is in het ontstaan van depressie en angststoornissen, maar ook van overspanning en burnout. Deze laatste aandoeningen zijn niet expliciet opgenomen in de DSM-IV (APA, 2001), en daarom zijn we er in dit rapport niet uitgebreid op ingegaan.

De kenmerken van overspanning en burnout vertonen veel overeenkomsten met die van angststoornissen en depressie (Brouwers et al., 2005). Daarnaast is er sprake van duidelijke overeenkomsten tussen de preventieve interventies. Soms worden interventies zelfs met elkaar gecombineerd, zoals in de begeleide internetcursus 'Alles onder controle' (Cuijpers, 2004c; paragraaf 3.4.2).

Vooral voor geïndiceerde preventie van burnout zijn er duidelijke overeenkomsten met de in hoofdstuk 3 en 4 beschreven interventies. Zo blijkt uit een meta-analyse dat de cognitief-gedragstherapeutische geïndiceerde preventieve interventies voor burnout het meest effectief zijn (Van der Klink et al., 2001). In het buitenland worden dergelijke cursussen ook via internet aangeboden (Zetterqvist et al., 2003). De werkstresstrainingen bevatten ten opzichte van de eerder beschreven interventies voor angststoornissen en depressie vaak enkele extra elementen, zoals time-management, assertiviteit en lichamelijke stress-management (Gotink et al., 2005; Leffers et al., 2000; Van Rhenen et al., 2005).

Werkstresspreventie leent zich goed voor een integrale aanpak op de werkplek (Michie \& Williams, 2003). Deze aanpak wordt tegenwoordig vaak beschreven in zogenaamde 'arboconvenanten', documenten waarin werkgevers- en werknemersorganisaties per sector afspraken maken over de werkomstandigheden. In een aantal van deze arboconvenanten is inmiddels expliciet aandacht voor de preventie van psychische overbelasting en burnout. Helaas zijn slechts enkele van deze preventieprogramma's goed omschreven en openbaar. Een goed voorbeeld is het preventieprogramma 'Psychische Belasting' uit het arboconvenant voor academische ziekenhuizen 2003 (www.arboconvenantacademischeziekenhuizen.nl). Doelgroep vormen de leidinggevenden in academische ziekenhuizen. Het doel is om leidinggevenden te leren om knelpunten op het gebied van psychische belasting van hun medewerkers beter te signaleren en op te lossen. Het preventieprogramma is opgebouwd uit verschillende stappen. Bij de stap 'interventie' is er op de website een overzicht beschikbaar van interventies die aangeboden kunnen worden. Deze variëren van een weerbaarheidstraining voor medewerkers tot intervisie, time-management en een stress-burnouttraining door professionals. 
organisatorisch onderdeel van de tweedelijns gezondheidszorg en om die reden fysiek gehuisvest in de GGZ-instellingen. Maar daarnaast werken veel van deze instellingen samen met eerstelijns hulpverleners, waarbij hulpverleners worden gedetacheerd in huisartsenpraktijken. Ook zijn er samenwerkingsverbanden tussen de GGZ-preventie en GGD-en, waarbij de GGZ de GGD samenwerken aan een lokaal beleid. Tot slot zijn er scholen die hun onderwijzend personeel laten trainen in het herkennen van psychische problemen bij kinderen, waarbij de trainingen worden verzorgd door de GGZ-preventiemedewerkers. Een dergelijk voorbeeld is ook voor andere samenwerkingsvormen uit te werken.

De nuldelijn vormt een belangrijk werkgebied voor preventie. De preventieve activiteiten bestaan voornamelijk uit universele en selectieve preventie gericht op gezondheidsbevordering. Dit aanbod bestaat onder andere uit psycho-educatie en specifieke lesprogramma's gericht op bepaalde thema's op scholen. Een voorbeeld is schoolprogramma 'De Gezonde school en genotmiddelen' (paragraaf 5.4.1). Ook bepaalde overheidsmaatregelen kunnen beschouwd worden als vorm van universele preventie, zoals accijnsverhoging of beperking van beschikbaarheid van alcohol ter preventie van alcoholmisbruik en -afhankelijkheid (hoofdstuk 5). Het aanbod in de vorm van geindiceerde en selectieve preventieprogramma's binnen de openbare gezondheidszorg bestaat uit vroegherkenning en vroegbehandeling. In de openbare gezondheidszorg vormt preventie van psychische problemen die tot maatschappelijke overlast leiden een belangrijk onderdeel, met name schadelijk alcohol- en drugsgebruik. Preventie van depressie en angststoornissen is binnen de openbare gezondheidszorg een nog relatief onbekend terrein (Ruiter et al., 2005).

Binnen de eerstelijn vormt preventie slechts een klein onderdeel van het zorgaanbod. De mate waarin en de manier waarop eerstelijns hulpverleners zich bezig houden met preventie verschillen. Meestal gaat het om geïndiceerde preventie. Alleen de bedrijfsarts voert ook universele preventieve activiteiten uit (tekstblok 7.1). Vroegherkenning en vroegbehandeling van psychische klachten zou meer in de eerstelijn gestalte kunnen krijgen. Over het geheel genomen gebeurt dit tot nu toe niet of nauwelijks via gestandaardiseerde evidence-based preventieprogramma's.

De tweedelijns GGZ is op dit moment de belangrijkste aanbieder van preventieve interventies voor psychische stoornissen. Veel van de programma's die werden ontwikkeld in de tweedelijns GGZ worden steeds vaker ook aangeboden binnen andere settings in de nulde- en eerstelijn, meestal in samenwerking met de tweedelijns GGZ. Dit komt het bereik van de interventies zeker ten goede. Overigens vormt preventie binnen de tweedelijns GGZ maar een klein onderdeel, vergeleken bij de afdelingen cure en de care. Binnen de somatische tweedelijn - zoals ziekenhuizen en verpleeghuizen - wordt de laatste jaren ook wel het een en ander aan preventie van psychische stoornissen gedaan. Hier is echter nog veel winst te behalen. 


\subsubsection{Wettelijke kaders en financiering}

De taken, verantwoordelijkheden en bevoegdheden van de overheid voor de preventie van psychische stoornissen zijn vastgelegd in verschillende wettelijke kaders. Als gevolg hiervan is ook de financiering van preventieve activiteiten erg versnipperd. Hieronder lichten we de wettelijke kaders toe die rechtstreeks gerelateerd zijn aan de conclusies en aanbevelingen van het themarapport. Dit zijn de Wet Collectieve Preventie Volksgezondheid (WCPV), de Wet Maatschappelijke Ondersteuning (WMO) en de Zorgverzekeringswet. De WCPV en de WMO zijn de wettelijke kaders voor de collectieve GGZ-preventie. In de preventiepraktijk is dat de niet tot individuen herleidbare preventie. Dit kan zowel universele als selectieve preventie zijn. De Zorgverzekeringswet regelt de individuele preventie. In de preventiepraktijk kan dat zowel geïndiceerde als selectieve preventie zijn.

\section{WCPV}

In de WCPV zijn de taken en verantwoordelijkheden van de gemeente ten aanzien van collectieve preventie op het gebied van volksgezondheid vastgelegd (De Vries, 2006; tekstblok 7.2). Daarnaast regelt de WCPV sinds 1989 het bestaan van een landelijk dekkend netwerk van GGD-en en de aansturing van de GGD door de gemeente. Ook legt de wet aan de gemeenten een aantal taken op, zoals de verplichting om gezondheidsbeleid te voeren, om de gezondheidssituatie van de bevolking te bewaken en om taken op het terrein van de jeugdgezondheidszorg en de infectieziektenbestrijding uit te voeren (VWS, 2000a).

In het kader van de WCPV zijn gemeenten sinds 1 juli 2003 verplicht om eens per vier jaar in een nota lokaal gezondheidsbeleid vast te leggen wat hun ambities en keuzes op het gebied van volksgezondheid en preventie zijn (Ruiter et al., 2005). In de afgelopen jaren hebben vrijwel alle gemeenten dit gedaan. De nota's lokaal gezondheidsbeleid - in totaal 175 stuks - zijn in 2004 geanalyseerd door GGD Nederland. Uit deze analyse blijkt dat twee derde van de 117 gemeenten in de nota lokaal gezondheidsbeleid aandacht besteedt aan de openbare GGZ (GGD Nederland, 2004). Ongeveer de helft maakt extra geld vrij voor preventie in het kader van de openbare GGZ. De belangrijkste onderwerpen zijn preventie van riskant genotmiddelengebruik bij de jeugd (60\%) en de preventie van vereenzaming bij ouderen (58\%). Preventie van depressie en angst zijn grotendeels nog nieuwe thema's voor gemeenten.

De rol van de landelijke overheid bestaat er uit om in het kader van de WCPV vierjaarlijks een landelijke nota uit te brengen, waarin de landelijke beleidsspeerpunten voor preventie worden vastgelegd (Algemene Rekenkamer, 2003). Daarmee schept ze een kader voor het gemeentelijke beleid voor preventie. Met de recente nota 'Kiezen voor gezond leven' (VWS, 2006d) is voor de tweede maal aan deze verplichting voldaan. Ook heeft de landelijke overheid de taak te zorgen voor een landelijke ondersteuningsstructuur voor collectieve preventie, moet ze de interdepartementale en internationale samenwerking bevorderen en is ze bevoegd regels te stellen voor informatieverstrekking door gemeenten. 


\section{Tekstblok 7.2: Voorbeelden lokaal integraal gezondheidsbeleid.}

Op gemeentelijk niveau verplicht de Wet Collectieve Preventie Volksgezondheid (WCPV) gezondheidsaspecten in bestuurlijke beslissingen te bewaken ofwel om integraal gezondheidsbeleid te voeren. Dat geldt voor veel beleidsterreinen, waaronder jeugd, welzijn, wonen, werk en inkomen, onderwijs, veiligheid, sport en transport. Hieronder volgen enkele mogelijke aangrijpingspunten voor lokaal integraal gezondheidsbeleid ter preventie van psychische stoornissen.

\section{Jeugd \\ In het kader van de preventie van psychosoci- ale problematiek is opvoedingsondersteuning volop in ontwikkeling bij het jeugdbeleid voor 0 -19-jarigen. Het doel hiervan is het voorko- men van emotionele en gedragsproblemen bij de betrokken kinderen en het bevorderen van de daartoe benodigde opvoedingsvaardig- heden bij ouders. Deze aanpak is effectief gebleken in Australië (Scanlon, 1997). In Leiden en Den Bosch is ook met deze integrale aanpak gestart door NIZW en Trimbos-instituut. Deze aanpak krijgt vorm door een beperkte mas- samediale campagne, consultatieprogram- ma's, intensieve training vanwege meerdere gedragsproblemen, woedeaanvallen van het kind en vechtpartijen.}

\section{Onderwijs}

De sector onderwijs speelt ook een belangrijke rol bij de preventie van psychische stoornissen. Vooral bij onderwerpen als sociale, probleemoplossings- en andere vaardigheden van leerlingen op school en het riskant middelen gebruik. Daarnaast kunnen docent leren psychosociale problemen bij leerlingen te signaleren en kennis aandragen over de psychische kanten van problemen als overgewicht. Zij werkt hierin samen met GGZ, JGZ/GGD, bureaus jeugdzorg en de sector welzijn. Er zijn in Nederland diverse initiatieven om het regionale of lokale aanbod richting scholen te bundelen. Een verankering van deze activiteiten in het gemeentelijk onderwijsbeleid en een bijdrage uit de gemeentelijk onderwijsgelden kan een enorme stimulans zijn deze activiteiten te stimuleren. In het kader van 'de gezonde school' is ook aandacht voor de preventie van pesten, het bevorderen van de sociaal-emotionele ontwikkeling (bv. door leren sociale vaardigheden), preventie van riskant genotmiddelengebruik. Programma's die schooluitval verminderen komen ook aan bod in Operatie Jong.
Welzijn

Het realiseren van sociale voorzieningen (zoals ontmoetingscentra voor ouderen) of het realiseren van sociale steun en netwerken in de omgeving (Ruiter et al., 2005), heeft waarschijnlijk ook een effect op het ontstaan van depressie. Welzijnsbeleid is ook vaak achterstandsbeleid en heeft dus vaak betrekking op het bestrijden van isolatie, eenzaamheid, geweld en armoede. Dit zijn risicofactoren die ook een rol kunnen spelen bij het ontstaan van andere psychische stoornissen.

\section{Huisvesting}

Een recente overzichtstudie laat zien dat een verbetering van de huisvesting veelbelovende effecten heeft op fysieke en geestelijke gezondheid (Hosman et al., 2005). Hierdoor wordt minder stress ervaren, een betere ervaren gezondheid, meer sociale participatie en criminaliteit voorkomen. Woningbouwcorporaties zijn onmisbaar voor het creëren van sociale veiligheid in de wijk. Huisvestingsbeleid kan bijvoorbeeld gericht zijn op een spreiding van inwoners uit verschillende bevolkingsgroepen om een gezond leefklimaat in de wijk te bevorderen. Ook dient in dit beleid rekening te worden gehouden met jeugdigen en ouderen. Openbare ruimte (zoals buurtclubhuizen en jongerencentra) en woonruimte moeten worden afgestemd op de behoefte van jeugdigen. Voor ouderen kunnen woon-zorg vormen gerealiseerd worden met als doel het verminderen van eenzaamheid (Linnemann et al., 2001.).

\section{Veiligheid}

Een veilige leefomgeving is van belang bij de geestelijke gezondheid en gezond gedrag van mensen. Mogelijke universele maatregelen zijn veilige en goede fietspaden en kinderspeelplaatsen (weg met 'enge' plekken). Dit met als doel te voorkomen dat mensen worden lastig gevallen en schokkende ervaringen krijgen te verwerken en de fysieke en sociale vaardigheden van kinderen op jonge leeftijd te ontwikkelen. Veilige leefomgeving is mogelijk door justitie dichter in de wijk te brengen, terugdringen en voorkomen van geweld in publiek domein, het verminderen van overlast en criminaliteit, het verbeteren van de leefbaarheid door handhaving en toezicht en het verbeteren van de toegankelijkheid van voorzieningen. Deze maatregelen kunnen positief effect hebben op veiligheidsbeleving en mogelijk bijdragen aan het voorkomen van psychische stoornissen. 


\section{WMO}

Vanaf 1 januari 2007 wordt het wettelijk kader voor het bevorderen van de openbare geestelijke gezondheidszorg (OGGZ) van de WCPV naar de WMO overgebracht. (WMO, 2005). Voor de definitie van OGGZ in de WMO is aangesloten bij hetgeen nu in de WCPV hieronder wordt verstaan (zie WCPV): 'het signaleren en bestrijden van risicofactoren op het gebied van de openbare geestelijke gezondheidszorg, het bereiken en begeleiden van kwetsbare personen en risicogroepen, het functioneren als meldpunt voor signalen van crisis of dreiging van crisis bij kwetsbare personen en risicogroepen het tot stand brengen van afspraken tussen betrokken organisaties over de uitvoering van de openbare geestelijke gezondheidszorg' (VWS, 2006c).

Onder de OGGZ wordt ook de collectieve preventie van (ernstige) psychosociale problemen begrepen. In de praktijk richt de OGGZ zich echter meestal op (overlastgevende) zorgmijders met meervoudige problematiek (het voorkomen van erger). Collectieve GGZ-preventie richt zich op de gehele lokale bevolking (het voorkomen van problemen).

De WMO richt zich op participatie en ondersteuning. Er zijn negen prestatievelden, waaronder het bevorderen van sociale samenhang in en leefbaarheid van dorpen, wijken en buurten, het geven van informatie, advies en cliëntondersteuning en het bevorderen van de deelname aan het maatschappelijk verkeer en van het zelfstandig functioneren van mensen met een beperking of een chronisch psychisch of een psychosociaal probleem (VWS, 2006c; WMO, 2005). Er is een zeker spanningsveld tussen de WCPV en de WMO. In het kader van de WCPV is er sprake van meer landelijke sturing, terwijl bij de WMO de verantwoordelijkheid voor het beleid bij de gemeenten wordt gelegd.

Collectieve GGZ-preventie bij gemeenten wordt gefinancierd uit het Gemeentefonds. In het kader van de WCPV ontvangen alle gemeenten middelen in het Gemeentefonds. Dit blijft zo, ook nu het wettelijk kader van collectieve GGZ-preventie wordt overgebracht naar de WMO. De middelen vanuit het Gemeentefonds zijn overigens niet geoormerkt. Het budget dat vanuit de AWBZ wordt overgeheveld naar de WMO wordt uitgekeerd aan gemeenten in de vorm van een WMO-integratie-uitkering. Gemeenten kunnen zelf bepalen waaraan zij de middelen uit het Gemeentefonds besteden voor taken uit de WCPV en de WMO.

\section{Zorgverzekeringswet}

De Zorgverzekeringswet is een standaardzorgverzekering voor alle Nederlanders (VWS, 2006a). Deze verzekering verving het ziekenfonds, de particuliere ziektekostenverzekering en de publiekrechtelijke regelingen voor ambtenaren. De overheid stelt het wettelijk verzekerde standaardpakket samen. De wet is op 1 januari 2006 in werking getreden.

Vanaf 1 januari 2008 gaat het op genezing gerichte ('cure') deel van de GGZ over van de AWBZ naar de Zorgverzekeringswet (VWS, 2006c). De GGZ wordt daarmee niet langer beschouwd als een sector die los staat van de algemene curatieve gezondheidszorg. Ook activiteiten gericht op individuele preventie van psychische stoornissen vallen vanaf 
1 januari 2008 onder de Zorgverzekeringswet (VWS, 2004b). Individuele preventie van psychische stoornissen wordt daarmee volgens de wet beschouwd als integraal onderdeel van behandeling. Dit betreft geïndiceerde preventie en selectieve preventie voor zover deze tot individuen herleidbaar is.

De financiering van individuele preventie zal van 1 januari 2008 dus plaatsvinden via de Zorgverkeringswet. Een deel daarvan kan bekostigd worden via de systematiek van diagnose-behandel-combinaties (DBC's). Een ander deel kan bekostigd worden als aparte verrichting waarover afspraken tussen zorgaanbieder en verzekeraar gemaakt moeten worden. Tot 1 januari 2008 wordt preventie zoals aangeboden door GGZ-instellingen grotendeels vanuit de AWBZ bekostigd. Een zeer klein deel wordt betaald uit de eigen bijdrage van cliënten of uit projectsubsidies (Voordouw \& Schaeffer, 2005).

\subsubsection{Beleidsgeschiedenis preventie van psychische stoornissen}

De preventie van psychische stoornissen is beleidsmatig een vrij nieuw terrein. Voor een uitgebreid overzicht van de beleidsgeschiedenis verwijzen we naar bijlage 7. De belangrijkste bevindingen uit deze geschiedenis vatten we hieronder per leeftijdsgroep samen.

In het huidige preventiebeleid is de jeugd een belangrijke doelgroep, maar niet altijd in relatie tot preventie van specifieke psychische stoornissen. Beleidsvoornemens over preventie bij de jeugd zijn de afgelopen tien jaar vooral gericht op vroegtijdige signalering van psychische problemen en in het verlengde daarvan het versterken van samenhang in de preventie en (vroegtijdige) zorg voor jeugdigen. De preventie van schadelijk alcoholgebruik bij jongeren is wel een belangrijk onderwerp binnen het preventiebeleid, en hiervoor zijn concrete beleidsvoornemens geformuleerd.

In de Beleidsvisie GGZ (VWS, 1998) stonden voor het eerst concrete beleidsspeerpunten voor de preventie van psychische stoornissen bij volwassenen. Over de preventie van depressie, angststoornissen en alcoholverslaving bij volwassenen stonden in de vorige preventienota al concrete beleidsvoornemens, al vormden deze nog geen speerpunten voor het beleid (VWS, 2003a). Deze voornemens - vooral de implementatie van effectieve interventies in nulde- en eerstelijn - komen overigens goed overeen met de conclusies van dit rapport. Voorafgaand aan de eerste Preventienota zijn er alleen voor overmatig alcoholgebruik en burnout specifieke beleidsvoornemens geformuleerd.

Over de preventie van psychische stoornissen bij ouderen zijn binnen het recente preventiebeleid nog geen beleidsdoelen geformuleerd. Dergelijke beleidsdoelen zijn wèl binnen het ouderenbeleid opgesteld. Deze zijn met name gericht op het investeren in vroegsignalering: tijdige diagnosestelling en behandeling van depressies en angststoornissen. Ook in de afgelopen tien jaar is er wel wat aandacht geweest voor preventie van psychische problemen bij ouderen. De beleidsdoelen hebben geen betrekking op specifieke stoornissen, maar vooral op onderzoeksprogramma's. Vroegherkenning van psychische stoornissen bij ouderen. Over de preventie van alcoholproblematiek bij ouderen zijn nog geen beleidsdoelen geformuleerd. 


\subsubsection{Conclusie}

Bovenstaande maakt duidelijk dat zowel de praktische, organisatorische als de beleidsmatige context van preventie van psychische stoornissen versnipperd is. Binnen de gezondheidszorg is een grote verscheidenheid van hulpverleners die zich in verschillende settings bezighouden met preventie. Ook is er een sterke versnippering in de wetgeving en financiering. Daarbij wordt een scheiding aangebracht in typen preventie die niet aansluit bij de werkwijze in het veld, zijn de budgetten die gemeenten te besteden hebben niet geoormerkt, en is de exacte invulling van financiering nog onzeker. Al met al zijn de randvoorwaarden voor een voor systematische en gestandaardiseerde preventie van psychische stoornissen in de huidige situatie nog niet optimaal. Dit betreft de randvoorwaarden voor het landelijk beleid, het gemeentelijk beleid en de gezondheidszorg. Op welke manier de randvoorwaarden verbeterd zouden kunnen worden is het onderwerp van de volgende paragrafen.

Bij het formuleren van deze aanbevelingen stuitten we overigens op het probleem dat juist op het gebied van de organisatie, wetgeving en financiering van preventie van psychische stoornissen momenteel veel in verandering is. Denk aan DBC's, de WMO, de AWBZ en de Zorgverzekeringswet. In de hieronder geformuleerde aanbevelingen houden we rekening met de beleidsplannen zoals die medio 2006 bestonden. We zijn ons ervan bewust dat deze plannen nog kunnen wijzigen. Het is niet mogelijk om in dit themarapport op alle toekomstige beleidsveranderingen te anticiperen. Dat betekent enerzijds dat de aanbevelingen als gevolg van nieuwe politieke ontwikkelingen in een ander licht kunnen komen te staan. Maar anderzijds kunnen onze aanbevelingen juist worden gebruikt voor de praktische uitwerking van de bestaande beleidsplannen.

\subsection{Verankeren van preventie in landelijk beleid}

De landelijke overheid heeft verschillende mogelijkheden om de preventie van psychische stoornissen verder te stimuleren. Zo kan ze met beleidsnota's een helder en stimulerend kader scheppen voor initiatieven in de gezondheidszorg en op lokaal terrein. De overheid kan daarnaast met behulp van publieksvoorlichting de burger informeren over het preventieve aanbod, maar ook over de aard en ernst van de problemen waarmee mensen er terecht kunnen. Ook kan de overheid toezien op een soepele aansluiting in de praktijk tussen alle wet- en regelgeving op dit terrein. Tot slot kan de overheid ondersteunen bij de wetenschappelijke onderbouwing van de preventie van psychische stoornissen. Hieronder werken we elk van deze mogelijkheden nader uit.

In de landelijke preventienota ‘Kiezen voor gezond leven' die het Ministerie van VWS in oktober 2006 uitbracht, hebben preventie van depressie en schadelijk alcoholgebruik de positie van speerpunt van beleid gekregen (VWS, 2006d). Schadelijk alcoholgebruik had die positie al, voor depressie is dit nu de eerste keer. De informatie uit dit themarapport onderstreept het belang van deze positie. Het is immers mogelijk om met preventieve interventies de ziektelast als gevolg van deze psychische stoornissen te 
verminderen, de kwaliteit van leven van vele mensen te handhaven, en dat alles op een vermoedelijk kosteneffectieve manier. De voornemens uit de Preventienota worden nog geconcretiseerd in een landelijk actieplan.

De landelijke overheid kan bijdragen aan een groter bereik van selectieve en geïndiceerde preventie door het gericht inzetten van publieksvoorlichting over psychische stoornissen. Deze vorm van universele preventie kan helpen om in brede bevolkingslagen meer kennis en begrip te genereren ten aanzien van psychische stoornissen, wat mensen er zelf aan kunnen doen en bij wie zij terecht kunnen voor verdere hulp wanneer dat nodig mocht zijn. Daarmee kan het de stap naar een meer gerichte vorm van preventie vergemakkelijken.

Een goede verankering van preventie in zowel het gemeentelijk beleid als in de gezondheidszorg is een noodzakelijke randvoorwaarde voor brede implementatie van preventieve interventies. Gemeenten zijn meer gericht op universele interventies, de gezondheidszorg is meer gericht op individuele behandeling van mensen die al een psychische stoornis hebben. Geïndiceerde en selectieve interventies vormen een tussengebied waarop beide partijen actief moeten zijn. Beide deelterreinen hebben hun eigen wettelijke en financiële kaders - de Wet Collectieve Preventie Volksgezondheid, de Wet Maatschappelijke Ondersteuning en de Zorgverzekeringswet - en sluiten in de praktijk nog niet goed op elkaar aan. Verbetering in die aansluiting is nodig voor de verankering van een samenhangend preventieaanbod. Dit laatste geldt vooral voor integrale preventieprogramma's die zich zowel op het collectief als op het individu richten.

De afgelopen jaren heeft ZonMw heeft een belangrijke rol gespeeld in de verwetenschappelijking van de preventie van psychische stoornissen. Die lijn zou doorgezet moeten worden. Immers, de mate waarin mensen gebruik maken van een preventief aanbod, en ook de mate waarin bijvoorbeeld huisartsen patiënten zullen doorverwijzen naar een preventief aanbod, zal sterk afhangen van de kwaliteit van het preventieve aanbod. Het is daarom belangrijk dat eerst en vooral het preventieve aanbod evidence-based is. Informatie zoals die uit dit rapport zou toegankelijk moeten worden voor professionals en het publiek. Een keuzehulp voor preventie - analoog aan de keuzehulpen voor behandeling (Franx et al., 2006a) - zou daarbij kunnen helpen, bijvoorbeeld via de website www.kiesbeter.nl. Ook hierin zou de overheid een stimulerende rol kunnen spelen.

\subsection{Verankeren van preventie in gemeentelijk beleid}

Preventie zou zo dicht mogelijk bij de burger moeten worden aangeboden. Daarom zal ook preventie van psychische stoornissen meer dan voorheen onderdeel moeten worden van de voorzieningen die dicht bij de burger staan, met een lage toegangsdrempel. Ook zal vooral geïndiceerde preventie van psychische stoornissen een grotere plek moeten krijgen in settings buiten de gezondheidszorg, zoals scholen, werk en wijken. 
Door preventie meer te integreren met welzijnsvoorzieningen en gemeentelijke voorzieningen gericht op gezondheidsbevordering wordt ze toegankelijker.

Een groot deel van het beleid voor preventie van psychische stoornissen wordt vastgesteld op gemeentelijk niveau. De collectieve GGZ-preventie en de jeugdgezondheidszorg kunnen een basisaanbod voor preventie verzorgen dat afgestemd is op de gezondheidssituatie van de lokale bevolking. Ook biedt de gemeentelijke regierol mogelijkheden om preventie in settings in te bedden en tot een integrale aanpak van psychische problematiek te komen. Betrokken organisaties binnen de gezondheidszorg - zoals GGZ-instellingen, GGD-en, lokale organisaties voor welzijn, verslavingszorg en eerstelijns zorgaanbieders -zijn op gemeentelijk niveau het best samen te brengen. Brede samenwerking kan als expliciete eis worden opgenomen in de contracten tussen gemeenten en zorgaanbieders.

Naast het beleidsterrein van volksgezondheid wordt preventie van psychische stoornissen ook meegewogen in andere beleidsterreinen. Dat is dus beleid dat buiten de strikte gezondheidssfeer valt, maar waarbij toch sprake is van het voorkómen van gezondheidsschade en/of het bevorderen van gezondheid. Dit wordt integraal gezondheidsbeleid genoemd. Op gemeentelijk niveau verplicht de WCPV gezondheidsaspecten in bestuurlijke beslissingen te bewaken ofwel om integraal gezondheidsbeleid te voeren. Dat geldt voor veel beleidsterreinen: jeugd, welzijn, wonen, werk en inkomen, onderwijs, veiligheid, sport en transport. In tekstblok 7.2 staat een kort overzicht van enkele mogelijke aangrijpingspunten voor integraal gezondheidsbeleid ter preventie van psychische stoornissen op gemeentelijk niveau.

Een succesvol voorbeeld van een settingerichte en integrale aanpak is de Integrale Aanpak Depressiepreventie bij ouderen: een wijkgerichte aanpak waarbij GGD-en en overige relevante partijen met elkaar samenwerken (Bohlmeijer et al., 2005a, 2005b; Cuijpers \& Willemse, 2005; tekstblok 7.3). Het verdient aanbeveling om deze aanpak ook uit te werken voor andere leeftijdsgroepen.

Gemeenten hebben steeds meer de regie gekregen over preventie van psychische stoornissen, maar de concrete invulling van deze rol is nog niet helder ingevuld. Gemeenten geven vanuit de openbare GGZ tot nu toe vooral prioriteit aan preventie van riskant genotmiddelengebruik, vereenzaming van ouderen en brede opgroei- en opvoedingsondersteunende programma's voor kinderen en jongeren. Voor zover deze thema's aansluiten bij de lokale problematiek is dit uiteraard een terechte prioritering. De nieuwe rol biedt echter ook mogelijkheden om te werken aan thema's waar gemeenten nog weinig ervaring mee hebben. Voorbeelden hiervan zijn preventie van depressie en angststoornissen. Een stimulerende rol van de landelijke overheid op deze prioriteiten kan helpen deze kansen daadwerkelijk te benutten.

Om te kunnen bepalen welke preventieprogramma's ze willen inzetten voor hun doelgroepen zullen gemeenten goed op de hoogte moeten zijn van de behoefte van de inwoners en het aanbod van effectieve preventieprogramma's, ook als het gaat om individuele preventie. Veel gemeenten vinden zelf dat ze hier nog te weinig inzicht in 


\section{Tekstblok 7.3: Integrale aanpak Depressiepreventie bij ouderen.}

Door het Trimbos-instituut is in samenwerking met GGD Nederland een stappenplan ontwikkeld om binnen afzienbare tijd een infrastructuur voor preventie van depressie bij ouderen te realiseren: de integrale aanpak depressiepreventie ouderen. Deze stappen zijn elders uitvoerig beschreven (Bohlmeijer et al., 2005a, 2005b; Cuijpers \& Willemse, 2006). Een optimale infrastructuur voor preventie is niet in één keer te realiseren. Het doel is om met concrete, haalbare en pragmatische jaarplannen de infrastructuur stapsgewijs op te bouwen. In 2006 tot 2008 vindt een proefimplementatie plaats van de integrale aanpak depressiepreventie ouderen in drie gemeenten in Nederland. In Amerika en veel WestEuropese landen is met veel succes deze aanpak toegepast op preventie van gedragsproblemen bij jongeren. In Amerika wordt de methode (Communities that Care) op dit moment in 600 steden geïmplementeerd.

We illustreren de belangrijkste elementen van een dergelijke infrastructuur voor depressiepreventie.

- Bevolkingsprofiel. Een bevolkingsprofiel geeft inzicht in welke mate de prevalentie van depressie, risicofactoren en beschermende factoren per wijk. $0 p$ basis van dit bevolkingsprofiel kunnen keuzes in het preventiebeleid gemaakt worden ten aanzien van risicofactoren en risicogroepen en wijken. Een bevolkingsprofiel depressiepreventie is vrij eenvoudig te realiseren op basis van gemeentelijke statistieken, gegevens uit de lokale gezondheidsmonitor en gegevens van het centraal bureau voor de statistiek (CBS). Het centrum voor Bevolkingsonderzoek van het RIVM kan hierbij een centrale rol vervullen.

- Sociale kaart. Een sociale kaart biedt een overzicht van interventies en diensten die door relevante (zorg)instanties worden aangeboden en beschikbaar zijn in het kader van depressiepreventie. Een sociale kaart maakt het mogelijk om goed te verwijzen en om een goede fit tussen hulpvraag en aanbod te realiseren. Een sociale kaart maakt het mogelijk om op basis van een bevolkingsprofiel en behoeften van de bevolking gaten in het bestaande aanbod te ontdekken en nieuwe effectieve interventies en diensten te implementeren.

- Vroegherkenning. Huisartsen, maatschappelijk werkers, thuiszorgverpleegkundigen, leerkrachten, bedrijfsartsen komen zeer regel- matig in contact om ouderen met depressieve klachten. De aanleiding voor dit contact is echter in de meeste gevallen niet de depressie maar andere klachten en problemen. Dit vraagt van de zorgverleners alertheid om te signaleren, deskundigheid om door te vragen en te motiveren tot preventieve hulp. Daartoe dient training gericht op deskundigheidsbevordering beschikbaar te zijn en regelmatig te worden uitgevoerd.

- Ketenzorgbenadering. In elke gemeente dient een keten van preventie en zorg aanwezig te zijn. Deze keten bestaat uit algemene voorlichting (over geestelijk gezond ouder worden, universele preventie), eenmalige adviezen en consultatie (universele en selectieve preventie), uitgebreide consultatie (selectieve preventie), zelfhulpprogramma's (selectieve en geïndiceerde preventie), intensieve trainingen en groepswerk (geïndiceerde preventie), behandeling (curatie).

- Netwerkbenadering. Deze zorg- en preventieketen wordt gerealiseerd door een netwerk van zorg en andere dienstenaanbieders. Het is belangrijk dat de lijnen tussen de aanbieders kort zijn, dat men goed op de hoogte is van ieders diensten en producten.

- Evaluatie- en monitorsysteem. Evaluatieonderzoek en een monitor geven inzicht in het aantal verwijzingen, de mate waarin de beoogde doelgroep wordt bereikt, tevredenheid van de doelgroep, vermindering van de blootstelling aan relevante risicofactoren, vermindering van relevante klachten bij de doelgroepen. Indicatoren daarvoor kunnen veelal al uit bestaande gemeentelijke gezondheidsmonitors verkregen worden, al zal soms een kleine aanpassing in de gezondheidsmonitor noodzakelijk zijn.

Deze infrastructuur hoeft niet voor elk nieuw geestelijk gezondheidsprobleem opnieuw te worden opgetuigd. Preventie van andere psychische stoornissen (als angst of schadelijk alcoholgebruik) kan gebruik maken van eenzelfde infrastructuur. Voor alcohol bestaan overigens al plannen voor lokaal integraal beleid. Het internet zal een steeds grotere rol spelen in die infrastructuur. Internet is een belangrijk medium om interventies aan te bieden (zelfhulp, lotgenotencontact) maar kan bijvoorbeeld ook de monitor faciliteren, of behulpzaam zijn met het verspreiden van stappenplannen, draaiboeken, sociale kaarten e.d. voor de uitvoerende partijen. 
hebben om een centrale rol te vervullen in individuele preventie (Ruiter et al., 2005). Gemeenten hebben dus meer deskundigheid en ondersteuning nodig bij het opstellen van de gemeentelijke nota gezondheidsbeleid en de WMO-beleidsplannen . Een toegankelijk overzicht van effectieve preventieprogramma's voor psychische stoornissen en een leidraad voor de integrale aanpak van preventie zouden gemeenten hierbij kunnen helpen.

\subsection{Verankeren van preventie in de gezondheidszorg}

De gezondheidszorg wordt steeds meer geordend volgens de 'stepped-care' benadering, ook 'getrapte zorg' of 'ketenzorg' genoemd. Daarin wordt het zorgaanbod aangepast aan de ernst van de klachten van de zorgvrager. Dit is een efficiënte vorm van werken: bij lichte klachten voldoet immers vaak een niet-ingrijpende behandeling. Preventie, en met name preventie bij mensen met beginnende klachten, leent zich goed als minst ingrijpende interventie in zo'n zorgketen. Veel van mensen met beginnende psychische klachten worden immers gezien bij de zorg en vooral de eerstelijn. In de theoretische en praktische uitwerking van de getrapte zorg voor psychische stoornissen is aan preventie nog veel te weinig aandacht besteed.

Preventieafdelingen van de tweedelijns GGZ hebben veel expertise in het ontwikkelen en uitvoeren van geïndiceerde preventie. Het preventieaanbod vanuit een GGZ-instelling heeft echter een wat weggestopte positie. Zo voelen veel mensen een hoge drempel om hulp te zoeken bij een GGZ-instelling, ook al gaat het om preventie. De expertise van de tweedelijns GGZ wordt daarom steeds meer ingezet binnen de nulde en de eerstelijn. Om de bereikbaarheid van preventieve interventies te vergroten is het noodzakelijk dat deze trend zich verder voortzet.

Zorgaanbieders binnen de eerstelijn zien veel patiënten met milde psychische klachten uit alle lagen van de bevolking en alle leeftijdsgroepen. Daarmee ligt er een belangrijke kans voor geïndiceerde preventie binnen de eerstelijn. Verschillende hulpverleners kunnen preventieve cursussen aanbieden die afgestemd zijn op hun eigen doelgroepen. Zo biedt het algemeen maatschappelijk werk uitgelezen kansen om preventie op een laagdrempelige manier toegankelijk te maken voor mensen met een lagere sociaal-economische status, terwijl de eerstelijnspsycholoog misschien weer beter is om andere doelgroepen te bereiken. Binnen de eerstelijn is de huisarts degene die de meeste mensen met psychische klachten ziet. De Doorbraakprojecten Depressie laten zien dat het mogelijk is om huisartsen een belangrijke rol te geven in het uitvoeren van en/of verwijzen naar effectieve preventieve interventies (Franx et al., 2006b). Dat geldt ook voor sociaal-psychiatrisch verpleegkundigen in de huisartsprakijk, het algemeen maatschappelijk werk, de thuiszorg en eerstelijnspsychologen. Voor mensen bij wie geïndiceerde preventie niet voldoende blijkt te zijn, is het behandelaanbod binnen de eerstelijn doorgaans een passend vervolg. Daarmee is de eerstelijn een belangrijke schakel in de ketenzorg van preventie naar behandeling. 
Psychische klachten worden nog onvoldoende herkend door hulpverleners in vooral de eerstelijn. De Regionale Ondersteunings Structuren (ROS-sen) voor de eerstelijnszorg die in 2005 zijn opgericht, kunnen hierbij een ondersteunende rol spelen door het faciliteren van deskundigheidsbevordering van huisartsen en algemeen maatschappelijk werk op het signaleren van psychische klachten. Ook de sociaal-psychiatrisch verpleegkundigen kunnen binnen de huisartspraktijk bijdragen aan betere herkenning van en verwijzen naar het preventie-aanbod. Dit geldt overigens ook voor andere hulpverleners in het somatische deel van de tweedelijnsgezondheidszorg (zoals ziekenhuizen en verpleeghuizen), in de nuldelijn en voor beroepsgroepen die regelmatig in contact staan met de doelgroep, zoals leerkrachten.

Wanneer de klachten wel worden herkend, dan ontbreekt het nu nog te vaak aan deskundigheid, afspraken en mogelijkheden om mensen met psychische klachten te motiveren en te verwijzen naar een preventieve interventie. Om de verschillende preventievormen goed op elkaar af te stemmen is een goede samenhang en samenwerking tussen aanbieders van preventieve interventies van belang.

Hulpverleners binnen de openbare en de eerstelijnsgezondheidszorg moeten goed op de hoogte zijn van elkaars preventie-aanbod en waar nodig naar elkaar verwijzen. Doel is om in iedere regio een gevarieerd aanbod beschikbaar te hebben, waardoor mensen met beginnende klachten zelf kunnen kiezen welke interventie het beste past bij de eigen situatie.

Maar het preventie-aanbod moet ook beter bekend worden bij de doelgroep zelf. Tot nu toe worden deelnemers vooral per afzonderlijke interventie geworven; dat is inefficiënt. Het zou beter zijn om (op regionaal niveau) deelnemers te werven met een breed aanbod van preventieve interventies, passend bij de diversiteit in hulpvraag en persoonlijke voorkeuren. Zo kunnen mensen zelf kiezen welke preventieve interventie het beste bij hen past.

Geïndiceerde preventie van psychische stoornissen maakt nog geen onderdeel uit van de NHG-standaarden voor de huisartsen, en evenmin staat het in de multidisciplinaire richtlijnen voor de GGZ (Landelijke Stuurgroep Multidisciplinaire Richtlijnontwikkeling in de GGZ, 2005a; Van Marwijk et al., 2003; Terluin et al., 2005). Deze richtlijnen zouden bij de eerstvolgende herziening meer moeten worden opgebouwd volgens de stepped-care benadering, waarbij geïndiceerde preventie als eerste stap verankerd wordt in het model van getrapte zorg. Vooral over de effectiviteit van de geïndiceerde preventie van depressie bestaat inmiddels voldoende evidentie om zo'n herziening te rechtvaardigen. De overzichten met de bewijskracht voor de effectiviteit in dit rapport kunnen daarbij dienstdoen als bron.

De financiering van preventieve interventies binnen de Zorgverzekeringswet is op dit moment niet helder geregeld. De DBC's voor de GGZ zijn nog in ontwikkeling. De betrokken partijen hebben een jaar uitstel gekregen (tot 1 januari 2008) om tot een definitieve financieringsstructuur te komen. Het verdient aanbeveling om daarbij ook 
een of meer heldere DBC's voor geïndiceerde preventie te ontwikkelen. Deze zijn in de voorlopige DBC-structuur zoals deze medio 2006 bestond, nog niet opgenomen. Met zulke DBC's wordt preventie zichtbaar als aparte interventievorm naast behandeling en is de vergoeding gegarandeerd. Op dit moment wordt door de zorgaanbieders vooral gezocht naar mogelijkheden om preventieve interventies vergoed te krijgen binnen de DBC's voor lichte stoornissen. Een nadeel van deze pragmatische aanpak is dat er onduidelijkheid blijft bestaan of geïndiceerde preventie wel of niet vergoed wordt. Overigens zullen de aanbieders van meer universeel gerichte preventieve interventies, die per definitie buiten de DBC's vallen, sowieso met de zorgverzekeraars moeten onderhandelen over de vergoeding daarvan. GGZ Nederland heeft imiddels voorgesteld om een 'GGZ Preventiefonds' op te richten dat beheerd wordt door privaat orgaan. Dit orgaan zou dan op basis van vastgestelde bestedings- en kwaliteitscriteria preventiegelden aan zorgverzekeraars kunnen toekennen. 


\section{Literatuur}

Akkermans M, Akkermans R, Hoevenaars A. Cursus 'Angst de baas 55+'. Cursistenmap. Delft: GGZ Delfland, 2003.

Algemene Rekenkamer. Rapport Preventieve gezondheidszorg. Tweede Kamer $(29300,2)$. Den Haag, 2003.

Allart-van Dam E. Indicated prevention of depression and prediction of outcome. The ‘Coping with Depression' course (proefschrift). Nijmegen: KUN, 2003.

Andrews G, Sanderson K, Corry J, Issakidis C, Lapsley $\mathrm{H}$. Cost-effectiveness of current and optimal treatment for schizophrenia. British Journal of Psychiatry, 2003; 183: 427-435.

Andrews G, Issakids C, Sanderson K, Corry J, Lapsley $\mathrm{H}$. Utilizing survey data to inform public policy: comparison of the cost-effectiveness of treatment of ten mental disorders. British Journal of Psychiatry, 2004; 184: 526-533.

Angst J. How recurrent and predictable is depressive disorder? In: Montgomery S, Rouiloon F (Eds.). Long-term treatment of depression. Perspectives in Psychiatry, 3. Chichester: Wiley, 1992.

APA, American Psychiatric Association. Beknopte handleiding bij de Diagnostische Criteria van de DSM-IV-TR (tweede druk). Lisse: Zwets \& Zeitlinger, 2001.

Arent SM, Landers DM. The effect of exercise on mood in the elderly. Medicine \& Science in Sports \& Exercise, 1999; 31: S347.

Arent SM. The effects of exercise on mood in older adults: a meta-analytic review. Journal of Aging and Physical Activity, 2000; 8: 407-430.

Babor TF, Ceatano R, Casswell S, Edwards G, Giesbrecht N, Graham K, et al. Alcohol: No ordinary commodity. Research and public policy. Oxford: University Press, 2003.

Balkom AJLM van, Dyck R van, Schoemaker C. Wat zijn angststoornissen en wat zijn de gevolgen? In: Volksgezondheid Toekomst Verkenning, Nationaal Kompas Volksgezondheid. Bilthoven: RIVM, <http://www. nationaalkompas.nl> Gezondheid en ziekte| Ziekten en aandoeningen| Psychische stoornissen\Angststoornissen, 13 december $2005 a$.
Balkom AJLM van, Dyck R van, Schoemaker C. Welke factoren beïnvloeden de kans op angststoornissen? In: Volksgezondheid Toekomst Verkenning, Nationaal Kompas Volksgezondheid. Bilthoven: RIVM, <http://www. nationaalkompas.nl> Gezondheid en ziekte| Ziekten en aandoeningen| Psychische stoornissen| Angststoornissen, 13 december 2005b.

Ballenger JC, Burrows GD, DuPont RL, Lesser IM, Noyes R, Pecknold JC, Rifkin A, Swinson RP. Alprazolam in panic disorder and agoraphobia: results from a multicenter trial, I: efficacy in short-term treatment. Archives of General Psychiatry, 1988; 45: 413-422.

Barrett PM, Sonderegger R, Sonderegger NL. Evaluation of an anxiety-prevention and positive-coping program (FRIENDS) for children and adolescents of non-English speaking background. Behaviour Change, 2001; 18: 78-91.

Batelaan NM, Graaf R de, Balkom AJLM van, Vollebergh WAM, Beekman ATF. De epidemiologie van paniek. Tijdschrift voor Psychiatrie, 2006; 48: 195-205.

Beardslee WR, Gladstone TR, Wright EJ, Cooper AB. A family-based approach to the prevention of depressive symptoms in children at risk: evidence of parental and child change. Pediatrics, 2003;112 (2): e119-131.

Beck AT, Steer RA, Garbin MG. Psychometric properties of the Beck Depression Inventory: twenty-five years of evaluation. Clinical Psychology Review, 1988; 8: 77-100.

Beekman ATF, Cuijpers P, Marwijk HWJ van, Smit F, Schoevers RA, Hosman C. Preventie van psychiatrische stoornissen. Nederlands Tijdschrift voor Geneeskunde, 2006; 150: 419-423.

Beekman ATF, Deeg DJH, Braam AW, Smit JH, Tilburg $W$ van. Consequences of major and minor depression in later life:a study of disability, well-being and service utilization. Psychological Medicine, 1997a; 27: 13971409.

Beekman ATF, Deeg DJH, Tilburg TG van, Schoevers RA, Smit JH, Hooijer D. Depressie bij ouderen in de Nederlandse bevolking: een onderzoek naar de prevalentie en risicofactoren. Tijdschrift voor Psychiatrie, 1997b; 39: 294-308. 
Beekman ATF, Deeg DJH, Tilburg T van, Smit JH, Hooijer Ch, Tilburg W van. Major and minor depression in later life: a study of prevalence and associated factors. Journal of Affective Disorders, 1995; 36: 65-75.

Beekman ATF, Ormel J. Depressie. In: Jong A de, Brink W van den, Ormel J, Wiersma D (Red). Handboek psychiatrische epidemiologie. Maarssen: Elsevier/De Tijdstroom, 1999.

Beurs E de, Beekman ATF, Balkom AJLM van, Deeg DJH, Tilburg W van. Consequences of anxiety in older patients: its effect on disability, well-being and use of health services. Psychological Medicine, 1999; 29: 583-593.

Benthem G, Elze J ten, Rijsewijk R van. 'Verlies... en dan verder'. Een cursus voor weduwen boven de zestig. Utrecht: Trimbos-instituut (Landelijk centrum GVO/sectie LOP-GGZ), 1994.

Bieleman B, Kruize A, Nienhuis A. Monitor alcoholverstrekking jongeren 2005 - Naleving leeftijdsgrenzen 16 en 18 jaar Drank- en Horecawet; metingen 1999, 2001, 2003 en 2005. Groningen: Stichting Intraval, 2006.

Bijl RV, Cuijpers P, Smit F. Psychiatric disorders in adult children of parents with a history of psychopathology. Social psychiatry and Psychiatric Epidemiology, 2001; 37: 7-12.

Bijl RV, Graaf R de, Ravelli A, Smit F, Vollebergh WAM. Gender and age-specific first incidence of DSM-III-R psychiatric disorders in the general population. Results from the Netherlands Mental Health Survey and Incidence Study (Nemesis). Social Psychiatry and Psychiatric Epidemiology, 2002; 37: 372-379.

Bijl RV, Ravelli A. Psychiatrische morbiditeit, zorggebruik en zorgbehoefte. Resultaten van de Netherlands Mental Health Survey and Incidence Study (Nemesis). Tijdschrift voor Gezondheidswetenschappen, 1998; 76, 446-457.

Bijl RV, Ravelli A. Current and residual functional disability associated with psychopathology: findings from the Netherlands Mental Health Survey and Incidence Study (Nemesis). Psychological Medicine, 2000; 30: 657-668.
Bijl RV, Ravelli A, Zessen G van. Prevalence of psychiatric disorder in the general population: results of the Netherlands Mental Health Survey and Incidence Study (Nemesis). Social Psychiatry and Psychiatric Epidemiology, 1998; 33: 587-595.

Bijl RV, Zessen G van, Ravelli A. Psychiatrische morbiditeit onder volwassenen in Nederland: het Nemesis-onderzoek. II. Prevalentie van psychiatrische stoornissen. Nederlands Tijdschrift voor Geneeskunde, 1997a; 141 (50): 2453-2460.

Bijl RV, Zessen G van, Ravelli A, Rijk C de, Langendoen Y. Psychiatrische morbiditeit onder volwassenen in Nederland: Het Nemesis-onderzoek. I. Doelstellingen, opzet en methoden. Nederlands Tijdschrift voor Geneeskunde, 1997b; 141: 2448-2452.

Blitterswijk F van. Big deal? Peereducatie als methode voor de preventie van riskant gebruik van genotmiddelen door jeugdigen. Amsterdam: SWP, 2004.

Bode C, Ridder DTD de. 'Op weg naar de gouden jaren'. Handleiding, design en instrumenten (intern rapport), Universiteit Utrecht: Capaciteitsgroep Gezondheidspsychologie, 2004.

Bode C, Ridder D de, Bensing J. Preparing for aging: Development, feasibility and preliminary results of an educational program for midlife and older based on proactive coping theory. Patient Education and Counseling, 2006; 61: 272-278.

Boer P den, Wiersma D, Bosch R van de. Why is self-help neglected in the treatment of emotional disorders? A meta-analysis. Psychological Medicine, 2004; 34: 959-971.

Boer S van den, Erp R van, Zande R van der. Draaiboek doe-praatgroep KOPP (8-12 jaar). Utrecht: Trimbos-instituut, 2002.

Bogt T ter, Dorsselaer S van, Vollebergh W. HBSC-Nederland 2002. Psychische gezondheid, risicogedrag en welbevinden van Nederlandse scholieren. Utrecht: Trimbosinstituut, 2003.

Bohlmeijer E. De verhalen die we leven. Utrecht: Trimbos-instituut. Te verschijnen november 2006.

Bohlmeijer E, Roemer M, Cuijpers P, Smit F. The effects of life-review on life-satisfaction and well-being in older adults: a meta-analytic approach. Mental Health and Aging (in druk). 
Bohlmeijer E, Smit F, Cuijpers P. Effects of reminiscence and life-review on late-life depression: a meta-analysis. International Journal of Geriatric Psychiatry, 2003a; 18: 1088-1094.

Bohlmeijer E, Smit F, Smits C. Integrale aanpak preventie van depressie bij ouderen. Introductie en onderbouwing. Utrecht: Trimbosinstituut, 2005a.

Bohlmeijer E, Smit F, Smits C, Onrust S, Toet J, Riper H. Integrale aanpak depressiepreventie ouderen. Handleiding. Utrecht: Trimbosinstituut, 2005b.

Bohlmeijer E, Valenkamp M, Westerhof G, Smit F, Cuijpers P. Creative reminiscence as an early intervention for depression: results of a pilot project. Aging and Mental Health, 2005c; 9: 302-304.

Bolier L, Riper H. Procesevaluaties homeparty's. Resultaten van het onderzoek naar het draaiboek homeparty's in de praktijk. Utrecht: Trimbos-instituut, 2004.

Bolier L, Sannen A, Hasselt N van. Handboek Uitgaan en Drugs: Werken aan preventie van riskant alcohol- en drugsgebruik in het uitgaanscircuit. Utrecht: Trimbos-instituut, 2005.

Bool M, TMK Doesum TMK van, Zanden RAP van der. Ontwikkeling en implementatie van preventieve interventies voor kinderen van ouders met psychische problemen of verslaving. Tijdschrift voor orthopedagogiek, kinderpsychiatrie en klinische kinderpsychologie, 2005; 30 (3-4): 150-161.

Boon B, Huiberts A. De effecten van Drinktest. nl. In voorbereiding.

Boot JM, Knapen MHJM. De Nederlandse gezondheidszorg. Utrecht: Utrecht Spectrum BV, 1986.

Bremmer MA, Beekman ARF, Deeg DJH, Balkom AJLM van, Dyck R van, Tilburg W van. Angststoornissen bij ouderen: prevalentie en risicofactoren. Tijdschrift voor Psychiatrie, 1997; 39 (8): 634-648.

Brilman EI, Brink W van den, Giel R. Omvang en lange termijn beloop van psychische stoornissen in de huisartsenpraktijk. Tijdschrift voor Psychiatrie, 1992; 34: 385-399.

Brink W van den. Verslavingen. In: Jong A de, Brink W van den, Ormel J, Wiersma D (Red.). Handboek psychiatrische epidemiologie. Maarssen: De Tijdstroom, 1999.
Brouwers EPM, Terluin B, Tiemens BG, Verhaak PFM. Lekenterm als diagnose. Medisch Contact, 2005; 60: 100-102.

Buist-Bouwman MA, Graaf R de, Vollebergh WA, Ormel J. Comorbidity of physical and mental disorders and the effect on work-loss days. Acta Psychiatrica Scandandinavica, 2005; 111: 436-443.

Busch MCM, Planken MJE. Wat zijn de effecten. In: VTV, Nationaal Kompas Volksgezondheid <http//www.nationaalkompas.nl>. Bilthoven: RIVM, 2005.

Callagham P. Exercise: a neglected intervention in mental health? Journal of Psychiatric \& Mental Health Nursing, 2004; 11: 476-483.

Can M, Voordouw I. Lichte dagen, donkere dagen. Cursus voor Turken en Marokkanen met depressieve klachten. Handreiking voor cursuscoördinatoren en -begeleiders. Utrecht: Trimbos-instituut/LSP, 2003.

CBO, Centraal BegeleidingsOrgaan voor de intercollegiale toetsing, Trimbos-instituut: Landelijke stuurgroep multidisciplinaire richtlijnontwikkeling in de GGZ. Multidiscipliniare richtlijn depressie. Richtlijn voor de diagnostiek en behandeling van volwassen cliënten met een depressie. Utrecht: Trimbos-instituut, 2005.

CBR, Centraal Bureau voor de Rijvaardigheid. Educatieve maatregel Alcohol en Verkeer. Rijswijk: CBR, 1996.

CBS, Centraal Bureau voor de Statistiek. Doodsoorzakenstatistiek. www.statline.nl $>$ kerncijfers $>$ mens en maatschappij > gezondheid en welzijn $>$ sterfte en doodsoorzaken, 24 oktober 2006.

Chisholm D, Rehm J, Ommeren M van, Monteiro M. Reducing the global burden of hazardous alcohol use: a comparatve cost-effectiveness anaysis. Journal of Studies Alcohol, 2004; 65: 782-793.

Clarke GN, Hawkins W, Murphy M, Sheeber LB, Lewinsohn PM, Seeley JR. Targeted prevention of unipolar depressive disorder in an at-risk sample of high school adolescents: A randomized trial of a group cognitive intervention. Journal of the American Academy of Child and Adolescent Psychiatry, 1995a; 34 (3): 312-321. 
Clarke GN, Hornbrook M, Lynch F, Polen M, Gale J, Beardslee W, O’Connor E, Seeley J. A randomized trial of a group cognitive intervention for preventing depression in a adolescent offspring of depressed parents. Archives of General Psychiatry, 2001; 58 (12): 1127-1134.

Clarke GN, Lewinsohn PM. Instructor's Manuel for the Adolescent Coping With Stress Course. Portland, Ore: Kaiser Permanente Center for Health Research, 1995b.

Clarke GN, Lewinsohn PM, Hops H. Instructor's Manuel for the Adolescent Coping With Depression Course. Portland, Ore: Kaiser Permanente Center for Health Research, 1990.

Cox JL, Holden JM, Sagovsky R. Detection of postnatal depression: Development of the 10-item Edinburgh Postnatal Depression Scale. British Journal of Psychiatry, 1987; 150: 782-786.

CPA, Commissie Psychische Arbeidsongeschiktheid. Leidraad. Aanpak verzuim om psychische redenen. 2001.

Cuijpers P. Bibliotherapy in unipolar depression: a meta-analysis. Journal of Behavior Therapy and Experimental Psychiatry, 1997; 28: 139-147.

Cuijpers PA. Psychoeducational Approach to the Treatment of Depression: A Meta-Analysis of Lewinsohn's 'Coping With Depression' Course. Behavior Therapy, 1998b: 29 (3): 521-533.

Cuijpers P. De effectiviteit van preventie van psychische problemen bij kinderen en jeugdigen. Tijdschrift voor Gezondheidswetenschappen, 2001; 97: 486-494.

Cuijpers P. Cursusmap In de put, uit de put. Zelf depressiviteit overwinnen. Baarn: HB Uitgevers/Trimbos-instituut, 2004a.

Cuijpers P. Cursus 55+ In de put, uit de put. Zelf depressiviteit overwinnen. Baarn: HB Uitgevers/Trimbos-instituut, 2004b.

Cuijpers P. Alles onder controle: uw problemen en zorgen overwinnen door zelfanalyse. Amsterdam: Vrije Universiteit, Afd. Klinische Psychologie, 2004c.

Cuijpers P, Bohlmeijer E. Preventie van psychische problemen vanuit de Geestelijke Gezondheidszorg. De effecten van groepsgerichte interventies. Utrecht: Trimbos-instituut, 2001.
Cuijpers P, Jonkers R, Weerdt I de, Jong A de. The effects of drug abuse prevention at school: 'The Healthy School and Drugs' project. Addiction, 2002; 97: 67-73.

Cuijpers P, Lammeren P van. Depressive symptoms in chronically ill elderly people in residential homes. Aging \& Mental Health, 1999; 3: 221-226.

Cuijpers P, Lammeren P van. Secondary prevention of depressive symptoms in elderly inhabitants of residential homes. International Journal of Geriatric Psychiatry, 2001; 16: 702-708

Cuijpers P, Osch B van. Leven met een chronische ziekte. Baarn: HBuitgevers/Trimbosinstituut, 2004.

Cuijpers P, Riper H, Lemmens L. The effects on mortality of brief interventions for problem drinking: a meta-analysis. Addiction, 2004; 99: 839-854.

Cuijpers P, Scholten M, Conijn B. Verslavingspreventie: een systematische overzichtsstudie. Den Haag: ZonMW, 2005a.

Cuijpers P, Smit F. Excess mortality in depression: A meta-analysis of community studies. Journal of Affective Disorders, 2002; 72: 227-236.

Cuijpers P, Smit F, Straten A van, aangeboden ter publicatie. Psychological treatment of subthreshold depression, a meta-analytic review.

Cuijpers P, Smit F, Voordouw I, Kramer J. Outcome of cognitive behaviour therapy for minor depression in routine practice. Psychology and Psychotherapy: Theory, Research and Practice, 2005b; 78: 179-188.

Cuijpers P, Straten A van, Smit F. Preventing the incidence of new cases of mental disorders: a meta-analytic review. Journal of Nervous and Mental Disease, 2005c; 193: 119-125.

Cuijpers P, Straten A van, Smits N, Smit F. Screening and early psychological intervention for depression in schools: systematic review and meta-analysis. European Child and Adolescent Psychiatry, 2006; 188: 330-336.

Cuijpers P, Willemse G. Integrale aanpak. Preventie van depressie bij ouderen. Een overzicht van interventies. Utrecht: Trimbosinstituut, 2005. 
Dadds MR, Spence SH, Holland DE, Barrett PM, Laurens KR. Prevention and early intervention for anxiety disorders: a controlled trial. Joural of Consulting and Clinical Psychology, 1997; 65: 627-635.

Dekker E. Hink-Stap-Sprong. Ontwikkelingsplan preventie geestelijke volksgezondheid en verslavingen (intern rapport). Den Haag, 1998.

Derogatis LR. SCL-90: administrative, scoring, and procedures manual-I for the (Revised) version. Baltimore: Johns Hopkins University School of Medicine, Clinical Psychometrics Research Unit, 1977.

Dijck D van, Knibbe RA. De prevalentie van probleemdrinken in Nederland. Een algemeen bevolkingsonderzoek. Maastricht: Universiteit Maastricht, 2005.

Dijkens ME. Tevredenheidsanalyse 'Zelf aan de slag'. Overzicht evaluaties zelfhulpcurssen 2003-2004. Amersfoort: Riagg Amersfoort \& Omstreken, 2004a.

Dijkens ME. 'Zelf aan de slag'. Evaluatieverslag 2003/2004. Amersfoort: Riagg Amersfoort \& Omstreken, 2004b.

Dyckman JM, Rosenbaum RL, Hartmeyer RJ, Walter LJ. Effects of psychological intervention on panic attack patients in the emergency department. Psychosomatics, 1999; 40: 422-427.

EC, Europese Commissie. Denkproces op hoog niveau over de mobiliteit van patiënten en de ontwikkelingen in de gezondheidszorg in de Europese Unie: uitkomst van het denkproces (HLPR/2003/16). Brussel: EC, 2003.

Eisses AM. Depressie bij verzorgingshuisbewoners: prevalentie, incidentie, risicofactoren en effecten van vroegsignalering (proefschrift). Groningen: RijksUniversiteit Groningen, 2005.

Elling MW. Databank effectieve jeugdinterventies: beschrijving 'Stemmingmakerij'. Utrecht: NIZW. http://www.jeugdinterventies.nl, november 2005.

Emmelkamp PGM, Hoogduin CAL, Hout MA van den. Angststoornissen. In: Vandereycken W, Hoogduin CAL, Emmelkamp PMG. Handboek Psychopathologie. Deel 1 Basisbegrippen. Houten: Bohn Stafleu van Loghum, 2000.
Emmen MJ, Wollersheim H, Elving LD, Schippers GM, Bleijenberg G. Klinische lessen: Leefstijlinterventie bij patiënten met alcoholgerelateerde somatische problematiek. Nederlands Tijdschrift voor Geneeskunde, 2004; 148: 601-604.

Emst A van. Hoe minder te drinken. Utrecht: Trimbos-instituut, 1996.

The ESEMeD/MHEDEA 2000 Investigators. Prevalence of mental disorders in Europe: results from the European Study of the Epidemiology of Mental Disorders (Esemed) Project. Acta Psychiatrica Scandinavica, 2004 ; 109 (Suppl. 420): 21-27.

Fox KR. The influence of physical activity on mental wellbeing. Pubic health nutrition, 1999; 2: 411-418.

Franssen J, Bohlmeijer E. Op zoek naar zin. Een cursus rond het eigen levensverhaal voor ouderen met depressieve klachten. Begeleidersmap. Utrecht: Trimbos-instituut, 2003.

Franx G, Stalmeier P, Timmermans D. Keuzehulp in de zorg: de integratie van kennis en waarden Maandblad Geestelijke volsksgezondheid, 2006a; 61: 638-646.

Franx G, Spijker J, Huyser J, Doelder P de. Daling in depressie. Medisch Contact, 2006b; 40: 1592-1595.

Gardenswartz CA, Craske MG. Prevention of panic disorder. Behavior Therapy, 2001; 32: 725-737.

Geerlings SW, Beekman ATF, Deeg DJH, Tilburg van $W$. Physical health and the onset and persistence of depression in older adults: an eight-wave prospective community-based study. Psychological Medicine, 2000; 30: 369-380.

Geerlings M, AM Lissenburg. Evaluatieonderzoek naar de effectiviteit van de zomercursus 'Plezier op school'. Afstudeeronderzoek Ontwikkelingspsychologie, Universiteit Utrecht, 2005.

Gelissen T, Laenen W, Ebben N. Bewegen zonder zorgen. Draaiboek. Maastricht. Ter beschikking voor derden begin 2008.

Gerrits R, Zanden R van der, Conijn B, Visscher R. (in voorbereiding). Mastering your mood: an online preventive intervention in groups of young people with depressive symptoms. 
Gezondheidsraad. Risico's van alcoholgebruik bij conceptie, zwangerschap en borstvoeding. Den Haag: Gezondheidsraad, 2005; publicatie nr 2004/22.

GGD Nederland. OGGZ-activiteiten bij GGD-sen, stand van zaken in Nederland. Utrecht: GGD Nederland, 2004.

GGZ Nederland. Visiedocument GGZ nederland: 'De krachten gebundeld'. Utrecht: GGZ Nederland, 2004.

GGZ Nederland. Preventie biedt perspectief. Preventieprojecten binnen de GGZ. Amersfoort: GGZ Nederland, 2005.

GGZ Nederland. Notitie hoofdenoverleg verslavingspreventie, 10 maart 2006.

Gijsen R, Poos MJJC. Achtergronden en details bij cijfers uit huisartsenregistraties. In: Volksgezondheid Toekomst Verkenning, Nationaal Kompas Volksgezondheid. Bilthoven: RIVM, http://www.nationaalkompas. nl, 13 december 2005.

Gotink W, Heijningen E van, Knispel, A, Lith C van, Newton C, Santen A van, Schelling W, Voordouw I, Willemse A. Werkstresstraining. Utrecht: Trimbos-instituut, 2005.

Graaff D de. Zomercampagne 2002 'Ben jij sterker dan drank?'. Evaluatie van de peerbenadering. Haarlem: ResCon, 2002

Graaff D de, Poort E. Evaluatie van de zomercampagne 2003 'DRANK de kater komt later'. Haarlem: ResCon, 2003.

Gravesteijn C, Diekstra R, Wilde EJ de, Koren E. Effecten van 'Levensvaardigheden'. Een vaardigheidsprogramma voor adolescenten. Kind en Adolescent, 2004; 25: 277-290.

Haan E de, Wit CAM de. Angst- en stemmingsstoornissen. In: Vandereycken W, Hoogduin CAL, Emmelkamp PMG. Handboek Psychopathologie. Deel 1 Basisbegrippen. Houten: Bohn Stafleu van Loghum, 2000.

Haastrecht P van, Verweij A. Wat wordt met preventie gericht op allochtonen beoogd? In: Volksgezondheid Toekomst Verkenning, Nationaal Kompas Volksgezondheid. Bilthoven: RIVM, <http://www.nationaalkompas. nl> Preventie| Gericht op doelgroepen| Allochtonen, 23 september 2005.

Hains AA. Comparison of cognitive stress-reduction intervention program for adolescents, Journal of Counselling Psychology, 1992; 37 (1): 79-84.
Haringsma R, Engels GI, Cuijpers P, Spinhoven P. Effectiveness of the coping with depression course for older adults provided by the community-based mental health care system in the Netherlands: a randomized controlled field trial. International Psychogeriatrics, 2005; 17: 1-19.

Helsdingen Y van. 'Angst de baas'. Effectmeting van een preventieve cursus voor ouderen vanaf 55 jaar met lichte angstklachten (doctoraalscriptie). Katholieke Universiteit Nijmegen, 2004.

Hermanns J, Öry F, Schrijvers G (Inventgroep). Helpen bij opgroeien en opvoeden: eerder, sneller en beter. Een advies over vroegtijdige signalering en interventies bij opvoed- en opgroeiproblemen. Utrecht: Julius Centrum, 2005.

Hermens ML, Hout HP van, Terluin B, Windt DA van der, Beekman AT, Dyck R van, Haan $M$ de. The prognosis of minor depression in the general population: a systematic review. General Hospital Psychiatry, 2004; 26 (6): 453-462.

Hoeymans N, Gommer AM, Poos MJJC. Sterfte, ziekte en ziektelast voor 56 geselecteerde aandoeningen. In: Volksgezondheid Toekomst Verkenning, Nationaal Kompas Volksgezondheid. Bilthoven: RIVM, <http://www. nationaalkompas.nl> Gezondheid en ziekte| Sterfte, levensverwachting en DALY's $\mid$ Ziektelast in DALY's, 19 juni 2006.

Hollander AEM de, Hoeymans N, Melse JM, Oers JAM van, Polder JJ (Red.). Zorg voor gezondheid. Volksgezondheid Toekomst Verkenning 2006. RIVM-rapportnr. 270061003. Houten: Bohn Stafleu Van Loghum, 2006.

Hosman C, Jané-Llopis E, Saxena S (Eds.). Prevention of mental disorders: WHO, Prevention of mental disorders: effective interventions and policy options. Summary report. WHO, 2005.

Hudson JL, Flannery-Schroeder E, Kendall FC. Primary prevention of anxiety disorders. In JA Dozois, Dobson KS (Eds.). The prevention of anxiety and depression. Theory, research, and practice (p. 101-130). Washington: American Psychological Association, 2004.

Huiberts A, Boon B. Wat u drinkt, test u zelf. Een jaar alcoholadvies-op-maat via internet. G vakblad voor gezondheid en maatschappij, 2003a; 6: 28-29. 
Huiberts A, Boon B. Drinkadvies op maat of voorlichtingsfolder: wat werkt beter? Presentatie op het FADO 2003, Utrecht, 2003b.

IMHPA, Implementation Mental Health Promotion Action. http://www.imhpa.net, 24 oktober 2006.

International Early Psychosis Association Writing Group. International clinical practice guidelines for early psychosis. British Journal of Psychiatry, 2005; 187 (suppl. 48): s120-s124.

Jané-Llopis E, Hosman C (Projectleiders). Integrating mental health promotion interventions into countries' policies, practice and mental health care system (the IMHPA Project). I. Final Report to the European Commission DG SANCO/G, October 25th, 2005.

Jansen J. Wat is openbare gezondheidszorg? In: Volksgezondheid Toekomst Verkenning, Nationaal Kompas Volksgezondheid. Bilthoven: RIVM, <http://www.nationaalkompas. nl> Zorg\ Openbare gezondheidszorg, 19 oktober 2006.

Jorm AF, Christensen H, Griffiths KM, Roders

B. Effectiveness of complementary and self-help treatments for depression. Medical Journal of Australia, 2002; 176: S84-S96.

Kaltenthaler E, Shackley P, Stevens K, Beverly C, Parry G, Chilcott J. A systematic review and economic evaluation of computerised cognitive behaviour therapy for depression and anxiety. Health Technology Assessment, 2002; 6(22): 1-100.

Katz IR, Streim J, Permelee P. Prevention of depression, recurrences and comlications in later life. Preventive Medicine, 1994; 23: 743-750.

Kenardy J, McCafferty K, Rosa V. Internet-deliverered indicated prevention for anxiety disorders: A randomized controlled trial. Behavioural and Cognitive Psycotherapy, 2003; 31: 279-289.

Kessler RC, Avenevoli S, Merikangas KR. Mood disorders in children and adolescents: An epidemiologic perspective. Biological Psychiatry, 2001; 49: 1002-1014.

Kessler RC, Berglund P, Demler O, Jin R,Merikangas KR, Walters EE. Lifetime prevalence and age-of-onset distributions of DSM-IV disorders in the National Comorbidity Survey Replication. Archives of General Psychiatry, 2005; 62: 593-602.
Kiselica M, Baker S, Thomas R, Reedy S. Effects of stress incoculation training and anxiety, stress, and academic performance among adolescents, Journal of Counselling Psychology, 1994; 53(5): 603-611.

Klink JJL van der, Blonk RWB, Schene AH, Dijk $\mathrm{FJH}$ van. The benefits of interventions for work-related stress. American Journal of Public Health, 2001; 91: 270-276.

KPMG. Excessive alcohol consumption in the Netherlands: Trends and social costs. www. kpmg.nl/bea, 2001.

Kramer J, Riper H. Resultaten van een gerandomiseerd gecontroleerd onderzoek naar de effectiviteit van het zelfhulpboekje 'Hoe minder te drinken' (intern rapport). Utrecht: Trimbos-instituut, 2005a.

Kramer JJAM, Riper H Online zelfhulpcursus kleurjeleven voor volwassenen. Utrecht: Trimbos-instituut, 2005b.

Kruijshaar ME, Barendregt J, Vos T, Graaf R de, Spijker J, Andrews G. Lifetime prevalence estimates of major depression: An indirect estimation method and a quantification of recall bias. European Journal of Epidemiology, 2005; 20: 102-111.

Kruijshaar ME, Hoeymans N, Bijl RV, Spijker J, Essink-Bot ML. Levels of disability in Major Depression. Findings from the Netherlands Mental Health Survey and Incidence Study (Nemesis). Journal of Affective Disorders 2003; 77(1): 53-64.

Kühner C. Das Gruppenprogramm “Depression bewaeltigen” und seine Varianten - eine aktualisierte Metaanalyse. Verhaltenstherapie, 2003; 13: 254-262.

LADIS, Landelijk Alcohol en Drugs Informatie Systeem. Kerncijfers verslavingszorg 2004. Houten: Landelijk Alcohol en Drugs Informatiesysteem, 2005

Laitinen-Krispijn S, Bijl R. Mental disorders and emplyee sickness absence: the Nemesis study. Social Psychiatry \& Psychiatric Epidemiology, 2000; 35: 71-77.

Laitinen-Krispijn S, Bijl R. Werk, psyche en ziekteverzuim. Aard en omvang van psychische stoornissen, ziekteverzuim en zorggebruik in de beroepsbevolking. Utrecht: Trimbosinstituut, 2002. 
Lammeren P van, Geelen K. Verbitteren of verbeteren; evaluatie van een programma ter voorkoming van eenzaamheid en depressie bij oudere weduwen. Utrecht: NcGv (reeks 95-1), 1995.

Landelijke Stuurgroep Multidisciplinaire Richtlijnontwikkeling in de GGZ. Multidisciplinaire richtlijn depressie: richtlijn voor de diagnostiek en behandeling van volwassen cliënten met een depressie, 2005. Utrecht: Trimbos-instituut, 2005a.

Landelijke Stuurgroep Multidisciplinaire Richtlijnontwikkeling in de GGZ. Multidisciplinaire richtlijn schizofrenie: richtlijn voor de diagnostiek, zorgorganisatie en behandeling van volwassen cliënten met schizofrenie. Utrecht: Trimbos-instituut, 2005b.

Lawlor DA, Hopker SW.The effectiveness of exercise as an intervention in the management of depression: systematic review and meta-regression analysis of randomised controlled trials. British Medical Journal, 2001; 31 (322, 7289): 763-767.

Lee C, McGlashan TH, Woods SW. Prevention of schizophrenia, Can it be achieved? CNS Drugs, 2005; 19: 193-206.

Leffers FC, Vergunst AJ, Kleber RJ. Stress op het werk de baas: resultaten van een stresshanteringstraining. Gedrag en gezondheid : Tijdschrift voor Psychologie en Gezondheid, 2000; 28: 12-22.

Lemmers L, Kramer J, Conijn B, Riper H, Emst A. van. Minder Drinken. Amsterdam: Boom, 2006.

Lemmers L, Schulten I, Sannen A. Implementatiegraad 'De gezonde school en genotmiddelen' in het voortgezet onderwijs in het schooljaar 2002/2003. Utrecht: Trimbosinstituut, 2003.

Lewinsohn PM, Antonucci DO, Breckenridge JS, Teri L. The Coping With Depression Course. Eugene: Castalia Publishing Company, 1984. Lewinsohn PB, Clarke GN, Seeley JR, Rohde P. Major depression in adolescents: age at onset, episode duration, and time to recurrence. Journal of the American Academy of Child and Adolescent Psychiatry, 1994; 33: 809-818.

Lindt SM van de. Ontwikkelingen in de organisatie, omvang en inhoud van de Verslavingspreventie anno 2005. Utrecht: Trimbos-instituut, 2005.
Linnemann M, Linschoten P van, Royers T, Nelissen N, Nitsche B (Red.). Eenzaam op leeftijd. Interventies bij eenzame ouderen. Utrecht: NIZW, 2001.

Lions Clubs International \& Quest International. Leefstijl voor jongeren. Stichting Lions Quest Nederland. Amsterdam: Vrije Universiteit Amsterdam, 1990.

Lowry-Webster HM, Barrett PM. A universal prevention trial of anxiety and depressive symptomatology in childhood: preliminary data from an Australian study. Behaviour Change, 2001; 18: 36-50.

Lowry-Webster HM, Barrett PM. A universal prevention trial of anxiety symptomatology during childhood. Results at one-year follow-up. Behaviour Change, 2003; 20: 25-43.

LVE, Landelijke Vereniging Eerstelijnspsychologen. Profileren, positioneren en excelleren vanuit een nieuw perspectief. Beleidsprogramma 2006-2010, LVE, Amsterdam, 2005. Lynch FL, Hornbrook M, Clarke GN, Perrin N, Polen MR, O’Connor, Dickerson J. Cost-effectiveness of an Intervention to Prevent Depression in At-Risk Teens. Archives of General Psychiatry, 2005; 62: 1241-1248.

Maas IAM, Jansen J. Psychische (on)gezondheid. Determinanten en effecten van preventieve interventies. RIVM-rapport nr. 270555001. Bilthoven: RIVM, 2000.

Marks IM, Mathews AM. Brief standard self-rating for phobic patients. Behaviour Research and Therapy, 1979; 17: 263-267.

Marlowe KH. Early interventions for psychosis (Letter). British Journal of Psychiatry, 2004; 186: 262-263

Marwijk HWJ van, Grundmeijer HGLM, Bijl D, Gelderen MG van, Haan M de, Weel-Baumgarten EM van, et al. NHG-standaard Depressieve stoornis (eerste herziening). Huisarts \& Wetenschap, 2003; 46: 614-623.

Mason OJ, Beavon-Pearson J. Understanding the genesis of psychotic disorder: issues in the prediction and prophylaxis of those at 'ultra-high risk'. British Journal of Clinical Psychology, 2005; 44: 383-404.

McGlashan TH. Effect of an early detection programme on duration of untreated psychosis: part of the Scandinavian TIPS study. British Journal of Psychiatry, 2005; 187: (suppl. 48): s29-32. 
McGorry PD, Yung AR, Phillips LJ. The 'close-in' or ultra high-risk model: a safe and effective strategy for research and clinical intervention in prepsychotic mental disorder. Schizophrenia Bulletin, 2003; 29:771-90.

Medema K. Verslag van de pilot 'Zelf aan de slag'. Zeist: Altrecht Preventie, 2003.

Meerkerk GJ, Aarns T, Dijkstra RH, Weisscher P, Njoo K, Boomsma LJ. NHG-Standaard Problematisch Alcoholgebruik: tweede herziening. Huisarts \& Wetenschap, 2005; 48(6): 284-295.

Merry S, McDowell H, Hetrick S, Bir J, Muller N. Psychological and/or educational interventions for the prevention of depression in children and adolescents. The Cochrane Database of Systematic Reviews, 2004; 2, CD003380.

Meulenbeek P, Herzmanatus J, Smit F, Willemse G, Zanden R van der. Cursusmap 'Geen Paniek, leren omgaan met paniekklachten'. Utrecht: Trimbos-instituut/GGNet, 2005.

MHE, Mental Health Europe. http://www.mhesme.org/en/projects_impha.htm (Implementing mental health promotion action), 19 oktober 2006.

Michie S, Williams S. Reducing work related psychological ill health and sickness absence: a systematic literature review. Occupational and Environmental Medicine, 2003; 60: 3-9.

Mierlo F (Red.), Enk A van, Hoevenaars A, Huibers K, Linssen G, Frank L. Preventie van depressie in verzorgingshuizen. De draaiboeken. Utrecht: Trimbos-instituut, 2001.

Mierlo C van, Hees T van, Lieshout V van, Pronk M, Krale A. Cursusmap 'Angst in de hand'. Zeist: Altrecht preventie, 2005.

Mierlo C van, Aken C van, Krale A, Medema $K$, Plassche $H$ van de, Zoest $H$ van. Zelfhulpcursus 'Angstige gevoelens? Zelf aan de slag!'. Zeist: Altrecht Preventie, 2004.

Miller WR, Wilbourne PL. Mesa Grande: a methodological analysis of clinical trials of treatments for alcohol use disorders. Addiction, 2002; 97: 265-277.

MO Groep, Maatschappelijk Ondernemers Groep. Aan beide zijden van de voordeur. Positie en functies van het algemeen maatschappelijk werk (visiedocument). Utrecht: Maatschappelijk Ondernemers Groep, 2003. Molen HT van der. Hulp als onderwijs: effecten van cursussen voor verlegen mensen (proefschrift). Groningen: RUG, 1985.
Monshouwer K, Dorsselaer S van, Gorter A, Verdurmen J, Vollebergh W. Jeugd en riskant gedrag: Kerngegevens uit het Peilstationsonderzoek 2003. Utrecht: Trimbos-instituut, 2004.

Morrison AP, French P, Walford L, Lewis SW, Kilcommons A, Green J, Parker S, Bentall RP. Cognitive therapy for the prevention of psychosis in people at ultra-high risk: randomised controlled trial. British Journal of Psychiatry, 2004; 185: 291-297.

Mrazek PJ, Haggerty RJ. Reducing risks for mental disorders: frontier for preventive intervention research. Washington: National Academy Press, 1994.

Nägele R, Vissers J. Gedragseffecten van de EMA. Een evaluatieonderzoek naar de leeren gedragseffecten op middellange termijn van de Educatieve Maatregel Alcohol en Verkeer. TT00-119. Veenendaal: Traffic Test BV, 2000.

NDM. Jaarbericht 2005. Utrecht: Trimbos-instituut , 2006.

NIGZ, Nederlands Instituut voor Gezondheid en Zorg. Factsheet alcohol en werk. Woerden: NIGZ, 2006.

NIGZ, Nederlands Instituut voor Gezondheid en Zorg. Wat doet drank met u? (tweede druk). Woerden: NIGZ, 2000.

NIZW, Nederlands Instituut voor Zorg en Welzijn. Databank Effectieve Jeugdinterventies. www.jeugdinterventies.nl., 2005.

Nolen WA, Koerselman GF. Stemmingsstoornissen. In: Vandereycken W, Hoogduin CAL, Emmelkamp PMG. Handboek psychopathologie. Houten: Bohn Stafleu Van Loghum, 2000.

NVAB. Handelen van de bedrijfsarts bij werknemers met psychische klachten. Geautoriseerde richtlijn. Utrecht/Eindhoven: NVAB, 2000.

NVAB, Nederlandse Vereniging voor Arbeidsen Bedrijfsgeneeskunde. De bedrijfsarts en de eerste lijn. Over samenwerking, zorgverzekeringen en regionale ondersteuningsstructuren. Utrecht/Eindhoven: NVAB, $2005 a$.

NVAB, Nederlandse Vereniging voor Arbeidsen Bedrijfsgeneeskunde. Brief aan Ministerie van Volksgezondheid, Welzijn en Sport: Positie bedrijfsarts in de eerste lijn (kenmerk: 23 juni 2005, JM/ab 208-08), 2005b. 
NVAB. CBO-richtlijn Depressie: samenvatting voor de bedrijfsarts. http://nvab.artsennet. nl, 12 januari 2006.

Oers JAM van (Eindred.). Gezondheid op koers? Volksgezondheid Toekomst Verkenning 2002. RIVM-rapportnr. 270551001. Houten: Bohn Stafleu Van Loghum, 2002.

Offringa M, Assendelft WJJ, Scholten RJPM. Inleiding in evidence-based medicine: klinisch handelen gebaseerd op bewijsmateriaal. Houten: Bohn Stafleu Van Loghum, 2003.

Onrust S, Cuijpers P, Smit F, Bohlmeijer E. Predictors of psychological adjustment after bereavement. International Psychogeriatrics, 2006; 1-15.

Onrust S, Willemse G, Bout J van den, Cuijpers $\mathrm{P}$ (aangeboden ter publicatie). Prevention of psychological problems in older widowed individuals by means of visiting service: A randomised trial.

Oostenbrink JB, Bouwmans CAM, Koopmanschap MA, Rutten F. Manual for Costing: Methods and standard costs for economic evaluations in health care (in Dutch). Diemen: Health Insurance Board, 2004.

Os J van, Delespaul P. Toward a world consensus on prevention of schizophrenia. Dialogues in Clinical Neuroscience, 2005; 7: 53-67.

Österberg E. Do alcohol prices affect consumption and related problems? In: Holder HD, Edwards G (Eds.) Alcohol and Public Policy: Evidence and Issues, 1995; 145-163. Oxford: Oxford University Press.

Parnassia, psycho-medisch centrum, afd. Preventie. Programma depressie en angst. Liever bewegen dan moe. Draaiboek voor begeleiders. Den Haag: Parnassia, 2005.

Pauw TJ, Kramer P, Lennep van, Gerrits RS, Cuijpers P, Stikkelbroek Y. Trimbos-instituut, 1999.

Petruzello SJ, Landers DM, Hatfield BD, Kubitz KA, Schador W. A meta-analysis of the anxiety reducing effects of acute and chronic exercise: outcomes and mechanisms. Sports Medicine, 1991; 11: 143-182.

Phillips LJ, McGorry PD, Yung AR, McGlashan TH, Cornblatt B, Klosterkötter J. Prepsychotic phase of schizophrenia and related disorders: recent progress and future opportunities. Britisch Journal of Psychiatry, 2005; 187 (suppl. 48): s33-s44.
Plassche $\mathrm{H}$ van de. Evaluatierapport project Kopzorgen. Interventie voor mensen met milde angst/depressieklachten en professionals in Wijk bij Duurstede. Utrecht: Altrecht Preventie, 2004.

Pol F van de. Gereguleerde marktwerking in de GGZ. Maandblad Geestelijke volksgezondheid, 2005; 60: 1095-1107.

Rademakers G, Groen A. Cursus Leren omgaan met verlegenheid. Apeldoorn: Spatie: Centrum voor Geestelijke Gezondheid, 2003.

Radloff LS. The CES-D scale: A self-report depression scale for research in the general population. Applied Psychological Measurement, 1977; 1: 385-401.

Ravelli A, Bijl R, Zessen G van. Comorbiditeit van psychiatrische stoornissen in de Nederlandse bevolking; Resultaten van de Netherlands Mental Health Survey and Incidence Study (Nemesis). Tijdschrift voor Psychiatrie, 1998; 40 (9): 531-544.

Reis S, Petersen R, Gursky D, McNally RJ. Anxiety sensitivity, anxiety frequency and the predictions of fearfulness. Behaviour Research and Therapy, 1986; 24: 1-8.

Rhenen W van, Blonk RWB, Klink JJL van der, Dijk FJH van, Schaufeli WB. The effect of a cognitive and a physical stress-reducing programme on psychological complaints. International Archives of Occupational and Envirnmental Health, 2005; 78: 139-148.

Riper H, Bolier L, Vocht M de. Draaiboek homeparty. Amersfoort: GGZ Nederland, 2004.

Riper H, Conijn B. Evaluatieverslag pilot Drankjewel.nl (intern rapport). Utrecht: Trimbos-instituut, 2003.

Riper H, Kramer JJAM. Online zelfhulpcursus www.kleurjeleven.nl voor ouderen. Utrecht: Trimbos-instituut, 2004

Riper H, Kramer J, Conijn, B, Smit F. Effectiviteit van een online zelfhulpprogramma voor probleemdrinkers (www.minderdrinken.nl). Eindrapportage ZonMw. Utrecht: Trimbosinstituut, 2005.

Riper H, Kramer J, Smit F, Conijn B, Cuijpers P. 'Drinking Less'. An online self- help intervention: Results from an online randomised clinical trial (in voorbereiding).

Romeijnders ACM, Vriezen JA, Van der Klink JJL, Hulshof CTJ, Terluin B, Flikweert S, Baart PC. Landelijke Eerstelijns Samenwerkingsafspraak Overspanning (LESA Overspanning). Huisarts \& Wetenschap, 2005; 48(1): 20-23. 
Room R, Babor T, Rehm J. Alcohol and public health. The Lancet, 2005; 365: 519- 530.

Ruiter M. Preventie van depressie bij jongeren, probleemanalyse, ontwikkeling en evaluatie van de cursus 'Stemmingmakerij'. Maastricht: Unigraphic, Universiteit Maastricht, 1997.

Ruiter M, Bohlmeijer E, Blekman J. Derde gids Preventie van psychische stoornissen en verslavingen. Utrecht: Trimbos-instituut, 2005.

RVD, Rijksvoorlichtingsdienst. Campagne Jongeren en Alcoholgebruik. Eindrapportage. Den Haag: RVD, 2003.

Sambeek D van (Red.). Draaiboek pubergroep KOPP: Preventief groepsaanbod voor pubers (13-15 jaar) van ouders met psychische of verslavingsproblemen. Utrecht: Trimbosinstituut / Landelijke Steunfunctie Preventie, 2002.

Scanlon K, Williams M, Raphael B. Mental health promotion in NSW: conceptual framework for developing initiatives. NSW Health Department, Sydney, Australia, 1997.

Schaper HJ, Kox E, Huibers K, Staarink I. Helpen bij rouwverwerking. Een cursus voor vrijwilligers van een bezoekdienst voor weduwen en weduwnaars. Spectrum. Instituut voor Ondersteuning van Maatschappelijke Ontwikkelingen in Gelderland, 1997.

Schippers GM, Kaplan CD. Stoornissen door gebruik van alcohol en andere psychoactieve stoffen. In: Vandereycken W, Hoogduin CAL, Emmelkamp PMG (Red.). Handboek Psychopathologie. Deel 1, Basisbegrippen. Houten: Bohn Stafleu van Loghum, 2000.

Schoemaker C, Poos MJJC, Spijker J. Hoe vaak komt depressie voor? In: Volksgezondheid Toekomst Verkenning, Nationaal Kompas Volksgezondheid. Bilthoven: RIVM, <http:// www.nationaalkompas.nl> Gezondheid en ziekte|Ziekten en aandoeningen|Psychische stoornissen| Depressie, 13 december 2005.

Schoemaker CG, Rigter HGM, Graaf R de, Cuijpers P. Nationale Monitor Geestelijke Gezondheid. Jaarbericht 2002. Utrecht: Bureau NMG, 2002.

Schoemaker CG, Ruiter C de (Red.). Nationale monitor geestelijke gezondheid. Jaarboek 2003. Utrecht: Bureau NMG, 2003.

Schoemaker CG, Ruiter C de (Red.). Nationale monitor geestelijke gezondheid. Jaarboek 2004. Utrecht: Bureau NMG, 2004.
Schoemaker CG, Ruiter C de. Trimbos zakboek psychische stoornissen. Utrecht: De Tijdstroom, 2005.

Schoemaker C, Gageldonk A van, Spijker J, Ketelaars T. Deze behandeling werkt echt! Beproefde tips voor bevlogen sprekers. Maandblad Geestelijke volksgezondheid, 2006; 61: 48-58.

Schoevers, RA, Smit F, Deeg DJH, Cuijpers P, Dekker J, Tilburg W van, Beekman ATF. Prevention of late-life depression in primary care: do we know where to begin? American Journal of Psychiatry, 2006; 163:1611-1621. Scholten M, Pols J, Drost Y, Voordouw I (Red.). Consultatie in de eerstelijns GGZ. De praktijk van consultatie op lokaal niveau. Utrecht: Trimbos-instituut, 2005.

Scott J, Palmer S, Paykel E, Teasdale J, Hayhurst $\mathrm{H}$. Use of cognitive therapy for relapse prevention in chronic depression: cost-effectiveness study. British Journal of Psychiatry, 2003; 182: 221-227.

Shortt A, Barrett P, Fox T. Evaluating the FRIENDS program. A cognitive-behavioral group treatment for anxious children and their parents. Journal of Clinical Child Psychology, 2001; 30: 523-533.

Slobbe LCJ, Kommer GJ, Smit JM, Groen J, Meerding WJ, Polder JJ. Kosten van Ziekten in Nederland 2003; Zorg voor euro's 1. RIVM-rapport nr. 270751010. Bilthoven: RIVM, 2006.

Smit F, Beekman ATF, Cuijpers P, Graaf R de, Vollebergh W. Selecting key-Variables for depression prevention: results from a population-based prospective epidemiological study. Journal of Affective Disorders, 2004; 81: 241-249.

Smit F, Bohlmeijer E, Cuijpers P. Wetenschappelijke onderbouwing depressiepreventie. Epidemiologie, aangrijpingspunten, huidige praktijk, nieuwe richtingen. Utrecht: Trimbos-instituut, 2003a.

Smit F, Comijs HC, Schoevers R, Cuijpers P, Deeg D, Beekman A. Target groups for the prevention of late-life anxiety. British Journal of Psychiatry (in druk-a).

Smit F, Cuijpers P, Lemmers L, Jonkers R, Weerdt I de. Same prevention, different effects? Effect modification in an alcohol misuse prevention project among high-school juniors. Drugs: Education, Prevention and Policy, 2003b; 10(2): 185-193. 
Smit F, Cuijpers P, Oostenbrink J, Batelaan N, Graaf R de, Beekman A. Costs of common mental disorders: implications for curative and preventive psychiatry. Journal of Mental Health Policy and Economics (in druk-b).

Smit F, Ederveen A, Cuijpers P, Deeg D, Beekman A. Opportunities for cost-effective prevention of late-life depression: an epidemiological approach. Archives of General Psychiatry, 2006a; 63: 290-296.

Smit F, Kramer J, Riper H. Economic cost of excessive drinking, cost-effectiveness of treatments: review of the literature, new directions, and an agenda for the future (aangeboden ter publicatie).

Smit F, Willemse G, Koopmanschap M, Onrust S, Cuijpers P, Beekman A. Cost-effectiveness of preventing depression in primary care patients: randomised trial. British Journal of Psychiatry, 2006b; 188: 330-336.

Smits CHM. Beschermende factoren voor preventie van depressie bij ouderen. Een wetenschappelijke verantwoording in het kader van de film 'De kunst van het ouder worden'. In: De Kunst van het ouder worden. Stilstaan en doorgaan bij ingrijpende veranderingen. Handleiding bij de film, p. 12-19. Den Haag: Parnassia, Psychomedisch centrum, 2003.

Spapen S, Weerdt I de. Evaluatie van de zomercampagne 2000 'Ben jij sterker dan drank?’Haarlem: ResCon, 2000.

Spek V, Cuijpers P, Nyklícek I, Riper H, Keyzer J, Pop V. Internet-based cognitive behaviour therapy for symptoms of depression and anxiety: a meta-analysis. Psychological Medicine (in druk).

Spence SH. A measure of anxiety symptoms among children. Behaviour Research and Therapy, 1998; 38: 545-566.

Spielberger CD. State-Trait Anxiety Inventory. Palo Alto, CA: Consulting Psychologists Press, 1983.

Spijker J. Chronic depression. Determinants and cosequences of chronic major depression in the general population (proefschrift), 2002.

Spijker J, Schoemaker C. Wat is depressie en wat zijn de gevolgen? In: Volksgezondheid Toekomst Verkenning, Nationaal Kompas Volksgezondheid. Bilthoven: RIVM, <http:/| www.nationaalkompas.nl> Gezondheid en ziekte|Ziekten en aandoeningen|Psychische stoornissen| Depressie, 13 december 2005.
Stichting Pandora. www.zogeknogniet.nl, 25 oktober 2006.

Story TJ, Zucker BG, Craske MG. Secondary prevention of anxiety disorders. In: Dozois JA, Dobson KS (Eds.). The prevention of anxiety and depression. Theory, research, and practice. Washington: American Psychological Association, 2004; 131-160.

Stouthard MEA, Essink-Bot ML, Bonsel GJ, Barendregt JJ, Kramers PGN, Water HPA van de, Gunning-Schepers LJ, Maas PJ. Disability weights for diseases in The Netherlands. Rotterdam: Erasmus MC Rotterdam.

Straten A van, Cuijpers P, Smit N. (in voorbereiding) The effectiveness of a generic webbased self-help intervention on depression, anxiety, and stress.

Swinson RP, Soulios C, Cox BJ, Kuch K. Brief treatment of emergency room patients with panic attacks. American Journal of Psychiatry, 19 92; 149: 944-946.

Sytema S, Ormel J, Oldehinkel AJ. Angststoornissen. In Jong A de, Brink W van den, Ormel J, Wiersma D (Red.). Handboek psychiatrische epidemiologie. Maarssen: De Tijdstroom, 1999.

SZW, Sociale Zaken en Werkgelegenheid. Ziekteverzuim en arbeidsongeschiktheid. Brief van de staatssecretaris van Sociale Zaken en Werkgelegenheid aan de Tweede Kamer (22187, 140). Den Haag: Sdu Uitgevers, 2003.

SZW, Sociale Zaken en Werkgelegenheid. Arbeidsgehandicapten en reïntegratie. Brief van de minister van Sociale Zaken en Werkgelegenheid aan de Tweede Kamer (29461, 13). Den Haag: Sdu Uitgevers, 2005.

Terluin B, Heest FB van, Meer K van der, Neomagus GJH, Heman J, Aulbers LPJ, et al.. NHG-standaard Angststoornissen (eerste herziening). Huisarts \& Wetenschap, 2004; 47: 26-37.

Themacommissie ouderenbeleid. Rapport Themacommissie ouderenbeleid. Tweede Kamer $(29549,5)$. Den Haag: Sdu Uitgevers, 2005.

Timmerman JJM. Cursus ‘Angst de baas'. Cursistenmap volwassenen. Gebaseerd op de cursus 'Angst de baas 55+'. Delft: GGZ Delfland, 2004.

Trimbos-instituut. Facsheet 2 Preventie. Kinderen van ouders met psychische problemen. Trimbos-instituut, 2001. 
Trimbos-instituut / MO Groep. AMW en GGZ samen aan de slag met preventie van depressie (brochure). Utrecht: Trimbos-instituut / MO Groep, 2004.

UWV, Uitvoering Werknemersverzekeringen. Ziektendiagnosen bij uitkeringen voor arbeidsongeschiktheid 2002. Statistische informatie over medische classificaties in WAO, WAZ en Wajong 2002. Amsterdam: UWV, 2002.

Vachon ML, Lyall WA, Rogers J, Freedman Letofsky K, Freeman SJ. A controlled study of self-help intervention for widows. American Journal of Psychiatry, 1980; 137: 1380-1384. Veerman TJ, Schoemaker CG, Cuelenaere B, Bijl RV. Psychische arbeidsongeschiktheid. Een overzicht van actuele feiten en cijfers. Commissie Psychische Arbeidsongeschiktheid. Utrecht: Bureau AS/tri / Trimbos-instituut, 2001.

Verdurmen J, Have M ten, Dorsselaer S van, Land $H$ van 't, Vollebergh W, Graaf $R$ de. Psychische stoornissen bij mensen met een lichamelijke aandoening. Resultaten van de 'Netherlands Mental Health Survey and Incidence Study' (Nemesis). Utrecht: Trimbosinstituut, 2006.

Verdurmen J, Monshouwer K, Dorsselaer S van, Graaf R de. Bovenmatig drinken in Nederland. Uitkomsten van de "Netherlands mental health survey and incidence study' (Nemesis). Utrecht: Trimbos-instituut/NDM, 2003

Verhaak PFM, Groenendijk J, Zantinge EM, Vonk E, Voordouw I, Veen C van de. GGZ-consultaties aan de eerstelijnszorg (Registratie 2000-2004). Utrecht: NIVEL, 2005.

Verhulst FC, Ende J van der, Ferdinand RF, Kasius MC. De prevalentie van psychiatrische stoornissen bij Nederlandse adolescenten. Nederlands Tijdschrift voor Geneeskunde, 1997; 141 (16): 777-781.

Verweij A, Dam JJM ten. Wat wordt met preventie gericht op personen met een lage ses beoogd? In: Volksgezondheid Toekomst Verkenning, Nationaal Kompas Volksgezondheid. Bilthoven: RIVM, <http://www. nationaalkompas.nl> Preventie| Gericht op doelgroepen| Lage ses, 10 september 2006.
Vijgen SMC, Busch MCM, Wit GA de, Zoest F van, Schuit AJ. Economische evaluatie van preventie - Kansen voor het Nederlandse volksgezondheidsbeleid. RIVM-rapport nr. 270091001. Bilthoven: RIVM, 2005.

Visser A, Laurant M, Schattenberg G, Grol R. De rol van de huisarts inzake geestelijke gezondheidszorg; de resultaten van een landelijke enquête. Nijmegen: Centre fo Quality of Care Research (WOK), 2002.

Vollebergh W, Graaf R de, Have M ten, Schoemaker C, Dorsselaer S van, Spijker J, Beekman A. Psychische stoornissen in Nederland. Overzicht van de resultaten van Nemesis. Utrecht: Trimbos-instituut, 2003.

Voordouw I, Kramer J, Cuijpers P. Grip op je dip. Zelf je somberheid overwinnen. Een handreiking voor coördinatoren en begeleiders van de cursus voor jongvolwassenen (18-25 jaar). Utrecht: Trimbos-instituut/ Landelijke Steunfunctie Preventie, 2002a.

Voordouw I, Kramer J, Cuijpers P. In de put, uit de put. Zelf depressiviteit overwinnen. Een handreiking voor coördinatoren en begeleiders van de cursus voor volwassenen en 55+. Utrecht: Trimbos-instituut/ Landelijke Steunfunctie Preventie, 2002b.

Voordouw I, Osch B van, Terweij M. De cursus Leven met een chronische ziekte. Handreiking voor coördinatoren en begeleiders. Utrecht: Trimbos-instituut/ Landelijke Steunfunctie Preventie, 2005.

Voordouw I, Schaeffer B. Ontwikkelingen in de organisatie, omvang en inhoud van de ggzpreventie. Utrecht: Trimbos-instituut, 2005.

Vorst H van der, Engels R, Meeus W, Dekovic, Leeuwe J van. The role of alcohol-specific socialization in adolescents' drinking behaviour. Addiction, 2005; 100: 1464-1476.

Vorst H van der, Engels R, Meeus W, Dekovic, Vermulst A. Parental attachment, parental control and early development of alcohol use: a longitudinal study. Psychology of Addictive Behaviours, 2006; 20: 107-116.

Vos M, Berg K, Sambeek D van. Draaiboek pubergroep KOPP. Preventief groepsaanbod voor puber van ouders met psychische of verslavingsproblemen (13-15). Utrecht: Trimbos-instituut/ Landelijke Steunfunctie Preventie, 2002. 
Vries M de. Welke wetgeving heeft betrekking op de OGZ? In: Volksgezondheid Toekomst Verkenning, Nationaal Kompas Volksgezondheid. Bilthoven: RIVM, <http://www. nationaalkompas.nl> Zorg $\backslash$ Openbare gezondheidszorg, 18 oktober 2006.

Vries W de, Smits C. Geestelijke gezondheid en ouder worden. Informatieve huiskamerbijeenkomsten voor oudere Turkse en Marokkaanse vrouwen. Handleiding en draaiboek. Utrecht: Trimbos-instituut, 2004.

Vries W de, Smits C. Stap voor stap. Een preventieve cursus voor oudere Turken en Marokkanen met angstklachten. Cursistenboek. Utrecht: Trimbos-instituut, 2005.

VWS, Ministerie van Volksgezondheid, Welzijn en Sport. Nota Gezond en wel. Volksgezondheidsbeleid 1995-1998. Tweede Kamer (24126, 2), Den Haag: Sdu Uitgevers, 1995.

VWS, Ministerie van Volksgezondheid, Welzijn en Sport (1996). Modernisering ouderenzorg. Brief van de minister van Volksgezondheid, Welzijn en Sport aan de Tweede Kamer $(24333,17)$. Den Haag: Sdu Uitgevers, 1996.

VWS, Ministerie van Volksgezondheid, Welzijn en Sport. Preventiebeleid voor de volksgezondheid. Brief van de minister van Volksgezondheid, Welzijn en Sport aan de Tweede Kamer $(22894,14)$. Den Haag: Sdu Uitgevers, 1997a.

VWS, Ministerie van Volksgezondheid, Welzijn en Sport. Ouderenbeleid 1995-1998. Brief van de staatssecretaris van Volksgezondheid, Welzijn en Sport aan de Tweede Kamer $(24319,6)$. Den Haag: Sdu Uitgevers, 1997b.

VWS, Ministerie van Volksgezondheid, Welzijn en Sport. Geestelijke Gezondheidszorg. Brief van de minister van Volksgezondheid, Welzijn en Sport aan de Tweede Kamer (25424, 1). Den Haag: Sdu Uitgevers, 1997c.

VWS, Ministerie van Volksgezondheid, Welzijn en Sport. Geestelijke Gezondheidszorg. Brief van de minister van Volksgezondheid, Welzijn en Sport aan de Tweede Kamer over de openbare geestelijke gezondheidszorg $(25424,2)$. Den Haag: Sdu Uitgevers, 1997d.

VWS, Ministerie van Volksgezondheid,

Welzijn en Sport. Beleidsvisie geestelijke gezondheidszorg. Brief van de minister van Volksgezondheid, Welzijn en Sport aan de Tweede Kamer $(25424,6)$. Den Haag: Sdu Uitgevers, 1998.
VWS, Ministerie van Volksgezondheid, Welzijn en Sport. Openbare Gezondheidszorg. Brief van de minister van VWS aan de Tweede Kamer. (26598, 2). Den Haag: Sdu Uitgevers, 2000a.

VWS, Ministerie van Volksgezondheid, Welzijn en Sport. PEO-programma volksgezondheid en zorg 2000. Brief van de minister van Volksgezondheid, Welzijn en Sport aan de Tweede Kamer $(26856,2)$. Den Haag: Sdu Uitgevers, 2000b.

VWS, Ministerie van Volksgezondheid, Welzijn en Sport. Positionering Jeugdgezondheidszorg 0-19 jaar. Brief van de staatssecretaris van Volksgezondheid, Welzijn en Sport aan de Tweede Kamer $(27004,1)$. Den Haag: Sdu Uitgevers, 2000c.

VWS, Ministerie van Volksgezondheid, Welzijn en Sport. Zorgnota 2001. Hoofdstuk 2: Gezondheidsbevordering en bescherming. Tweede Kamer 2000-2001 (27401, 1 en 2). Den Haag: Ministerie van Volksgezondheid, Welzijn en Sport, 2000d.

VWS, Ministerie van Volksgezondheid, Welzijn en Sport. Zorgnota 2001. Bijlage 2: Gezondheidsbevordering en -bescherming. Tweede Kamer $(27401,3)$. Den Haag: Sdu Uitgevers, 2000e.

VWS, Ministerie van Volksgezondheid, Welzijn en Sport. Alcoholnota. Tweede Kamer 20002001 (27565, 2). Den Haag: Sdu Uitgevers, $2000 f$.

VWS, Ministerie van Volksgezondheid, Welzijn en Sport. Zorgnota 2001. Bijlage 5: GGZ, verslavingszorg, maatschappelijke opvang. Tweede Kamer $(27401,3)$. Den Haag: Sdu Uitgevers, 2000g.

VWS, Ministerie van Volksgezondheid, Welzijn en Sport. Nota Langer gezond leven; Ook een kwestie van gezond gedrag. Tweede Kamer $(22894,20)$. Den Haag: Ministerie van Volksgezondheid, Welzijn en Sport, 2003a.

VWS, Ministerie van Volksgezondheid, Welzijn en Sport. Geestelijke gezondheidszorg. Brief van de minister van Volksgezondheid, Welzijn en Sport aan de Tweede Kamer (25424, 47). Den Haag: Sdu Uitgevers, 2003b.

VWS, Ministerie van Volksgezondheid, Welzijn en Sport. Beleidsagenda 2004. Keuzes voor een houdbare en beter presterende zorg. Den Haag: Ministerie van Volksgezondheid, Welzijn en Sport, 2003c. 
VWS, Ministerie van Volksgezondheid, Welzijn en Sport, VNG, Vereniging van Nederlandse Gemeenten. Opvoed- en opgroeiondersteuning. De rol van de gemeente in het licht van de Wet op de Jeugdzorg. Den Haag: Ministerie van Volksgezondheid, Welzijn en Sport, 2004.

VWS, Ministerie van Volksgezondheid, Welzijn en Sport. Preventiebeleid voor de volksgezondheid. Brief van de minister van Volksgezondheid, Welzijn en Sport aan de Tweede Kamer $(22894,44)$. Den Haag: Sdu Uitgevers, 2004a.

VWS, Ministerie van Volksgezondheid, Welzijn en Sport. Invoering Diagnose Behandel Combinaties (DBC's). Brief van de minister van Volksgezondheid, Welzijn en Sport aan de Tweede Kamer $(29248,8)$. Den Haag: Sdu Uitgevers, 2004b.

VWS, Ministerie van Volksgezondheid, Welzijn en Sport. Jeugdagenda. Brief van de staatssecretaris van Volksgezondheid, Welzijn en Sport aan de Tweede Kamer $(29284,5)$. Den Haag: Sdu Uitgevers, 2004b.

VWS, Ministerie van Volksgezondheid, Welzijn en Sport. Evaluatie drank- en horecawet. Brief van de minister van VWS aan de Tweede Kamer $(29894,1), 2004 c$.

VWS, Ministerie van Volksgezondheid, Welzijn en Sport. Alcoholbeleid. Brief van de minister van Volksgezondheid, Welzijn en Sport aan de Tweede Kamer $(27565,29)$. Den Haag: Sdu Uitgevers, 2005a.

VWS, Ministerie van Volksgezondheid, Welzijn en Sport. Nieuwe regels betreffende maatschappelijke ondersteuning (Wet maatschappelijke ondersteuning) $(30131,3)$. Den Haag, Sdu Uitgevers, 2005b.

VWS, Ministerie van Volksgezondheid, Welzijn en Sport. Informatiebrochure Wet op de Jeugdzorg. Den Haag: Ministerie van Volksgezondheid, Welzijn en Sport, 2005c.

VWS, Ministerie van Volksgezondheid, Welzijn en Sport. www.brancherapporten.minvws. $\mathrm{nl}$ | sectoroverstijgende ontwikkelingen, 19 oktober 2006a.

VWS, Ministerie van Volksgezondheid, Welzijn en Sport. Jeugdzorg 2005-2008. Voortgangsbericht over de jeugdzorg. Brief van de staatssecretaris van Volksgezondheid, Welzijn en Sport aan de Tweede Kamer (29815, 31). Den Haag: Sdu Uitgevers, 2006b.
VWS, Ministerie van Volksgezondheid, Welzijn en Sport. Nieuwe regels betreffende maatschappelijke ondersteuning (Wet maatschappelijke ondersteuning). Eerste Kamer (30131, A). Den Haag: Sdu Uitgevers, 2006c.

VWS, Ministerie van Volksgezondheid, Welzijn en Sport. Preventienota Kiezen voor gezond leven. Den Haag, 2006d.

Warner R. Problems with early and very early intervention in psychosis. British Journal of Psychiatry, 2005; 187 (suppl. 48): s104-s107.

Westert GP, Verkleij H (Red). Zorgbalans. De prestaties van de Nederlandse gezondheidszorg in 2004. RIVM-rapport nr. 260602001. Bilthoven: RIVM, 2006.

WHO, World Health Organization. Composite International Diagnostic Interview (CIDI), version 2.1, 12-months. Geneva: WHO, 1997.

WHO, World Health Organization. Prevention of mental disorders. Effective interventions and policy options. Summary report. Geneva: WHO, 2004.

Wiegersma PA, Hoffman A, Zielhuis GA. Prevention of unhealthy behaviour by youth care in the Netherlands. Journal of Public Health Medicine, 2003; 22: 386-392.

Willemse G, Voordouw I, Cuijpers P. Bibliotherapie bij depressieve klachten. Gebaseerd op de cursus Omgaan met depressie. Een handreiking voor begeleiders. Utrecht: Trimbos-instituut/ Landelijke Steunfunctie Preventie, 2004a.

Willemse GRWM, Smit F, Cuijpers P, Tiemens BG. Minimal contact psychotherapy for subthreshold depression in primary care: a randomised trial. British Journal of Psychiatry, 2004b; 185: 416-421.

Witte KE. Wat zijn de determinanten van psychische (on)gezondheid? In: Volksgezondheid Toekomst Verkenning, Nationaal Kompas Volksgezondheid. Bilthoven: RIVM, <http://www.nationaalkompas.nl> Gezondheidsdeterminanten, 24 november 2004.

Witte KE. Wat is preventie? In: Volksgezondheid Toekomst Verkenning, Nationaal Kompas Volksgezondheid. Bilthoven: RIVM, <http://www.nationaalkompas.nl> Preventie, 11 september 2006.

WMO, Wet maatschappelijke ondersteuning. www.info-WMO.nl, 23 augustus 2005. 
Woods SW, Breier A, Zipursky RB, Perkins DO, Addington J, Miller TJ, Hawkins KA, Marquez E, Lindborg SR, Tohen M, McGlashan TH. Randomized trial of olanzapine versus placebo in the symptomatic acute treatment of the schizophrenic prodrome. Biological Psychiatry, 2003; 54: 453-464.

Yingling KW, Wulsin LR, Arnold LM, Rouan GW. Estimated prevalences of panic disorder in an emregncy department with acute chest pain. Journal of General Internal Medicine, 1993; 8: 231-235.
Zanden R van der, Conijn B, Visscher R, Gerrits R. Grip op je dip on line. Een preventieve groepsinterventie voor jongeren via internet. Maandblad Geestelijke volksgezondheid, 2005; 60 (5): 515.

Zetterqvist K, Maanmies J, Ström L, Andersson G. Randomized Controlled Trial of InternetBased Stress Management. Cognitive Behaviour Therapy, 2003; 32: 151-160.

Zwart WM de. Alcohol in de samenleving. State of the art, met aanzet tot discussie. Utrecht: Trimbos-instituut, 1998. 


\title{
BIJLAGE 1 MEDEWERKERS BELEIDS ADVIES GROEP WETENSCHAPPELIJKE ADVIESCOMMISSIE
}

\section{Medewerkers aan dit rapport}

\section{Auteurs}

Dr. Susan Meijer, RIVM

Drs. Filip Smit, Trimbos-instituut / VU

Dr. Casper Schoemaker (projectleider), RIVM

Prof. dr. Pim Cuijpers, Trimbos-instituut / VU

\author{
Met bijdragen van \\ Drs. Ernst Bohlmeijer, Trimbos-instituut \\ Drs. Mirjam Busch, RIVM \\ Drs. Ireen de Graaf, Trimbos-instituut \\ Drs. Aafje Knispel, Trimbos-instituut \\ Dr. Jeannet Kramer, Trimbos-instituut \\ Dr. Hans Kroon, Trimbos-instituut \\ Dr. Lex Lemmers, Trimbos-instituut \\ Drs. René Poos, RIVM \\ Drs. Ilse Storm, RIVM \\ Drs. Ineke Voordouw, Trimbos-instituut \\ Dr. Godelief Willemse, Trimbos-instituut \\ Dr. Ardine de Wit, RIVM
}

Wetenschappelijke adviseurs

Drs. Theo van Alphen, RIVM

Dr. Matthijs van den Berg, RIVM

Drs. Martijn Bool, Trimbos-instituut

Dr. Vivian Bos, RIVM

Drs. Ingeborg Bovendeur, RIVM

Drs. Lea den Broeder, RIVM

Drs. Barbara Conijn, Trimbos-instituut

Dr. Ron de Graaf, Trimbos-instituut

Dr. Nancy Hoeymans, RIVM

Dr. Guus de Hollander, RIVM

Drs. Peter Meulenbeek, Trimbos-instituut / GGNet

Prof. dr. ing. Hans van Oers, RIVM

Dr. Johan Polder, RIVM

Dr. Marijke Ruiter, Trimbos-instituut

Dr. ir. Jantine Schuit, RIVM

Dr. Carola Schrijvers, RIVM

Ir. Lany Slobbe, RIVM

Dr. Carolien Smits, Trimbos-instituut 
Dr. Jan Spijker, Trimbos-instituut / De Gelderse Roos

Prof. dr. Jan Swinkels, Trimbos-instituut / AMC

Dr. Marja Tijhuis, RIVM*

Dr. Henriëtte Treurniet, RIVM

Dr. Jacqueline Verdurmen, Trimbos-instituut

Drs. Antonia Verweij, RIVM

Drs. Rianne van der Zanden, Trimbos-instituut

Ondersteuning

Jan de Bie, Studio aan de Werf

Lummy Blömer, RIVM

Drs. ing. Henriette Giesbers, RIVM

Drs. Kristien Harmsen, Trimbos-instituut

Drs. Toine Ketelaars, Trimbos-instituut

Marjan Kramer, RIVM

Wout Niezen, RIVM

\section{Samenstelling Beleids Advies Groep VWS}

Drs. Wim Brunenberg (voorzitter), Directie Curatieve Zorg / Geestelijke

Gezondheidszorg

Drs. Thijske Fraanje, Directie Curatieve Zorg / Geestelijke Gezondheidszorg

Drs. Sabine Geerts, Directie Curatieve Zorg / Bekostiging

Ir. Laetitia Kuijpers, Directie Publieke Gezondheid / Openbare Gezondheidszorg

Drs. Brenda Langezaal, Directie Voeding, Gezondheidsbescherming en Preventie /

Alcohol Drugs en Tabak

Drs. Aaf Tiems, Directie Maatschappelijke Ondersteuning / Sociale Samenhang en Opvang

Dr. Harry Verkleij (waarnemer RIVM)

* Dr. Marja Tijhuis was betrokken bij de opzet van dit project. Helaas werd zij ernstig ziek in 2004. Ze overleed in 2005. 


\section{Samenstelling Wetenschappelijke Advies Commissie}

Dr. Erik van Ameijden, GGD Nederland

Prof. dr. Ton van Balkom, VU Medisch centrum / GGZ Buitenamstel

Prof. dr. Aartjan Beekman, VU Medisch centrum / GGZ Buitenamstel

Drs. Judith Blekman, Trimbos-instituut

Prof. dr. Roland Blonk, Universiteit Utrecht

Prof. dr. Rutger Engels, UMC St Radboud

Dr. André van Gageldonk, Trimbos-instituut

Dr. Leona Hakkaart - Van Roijen, Erasmus MC

Dr. Marianne Jünger, Universiteit Utrecht

Prof. dr. Jan Neeleman, UMC Utrecht

Prof. dr. Johan Ormel, UMC Groningen

Drs. Katrien de Ponti, GGZ Nederland

Drs. Heleen Riper, Trimbos-instituut

Drs. Esther Teunissen, VNG

Prof. dr. Frank Verhulst, Erasmus MC - Sophia Kinderziekenhuis 



\section{BIJLAGE 2 ACHTERGRONDEN BIJ DE METHODE}

In de paragrafen 2.2 tot en met 2.4 zijn allerlei methodologische uitgangspunten bij het maken van dit rapport vrij kort weergegeven. In deze bijlage gaan we op enkele onderdelen uitgebreider in. In deze bijlage hanteren we dezelfde indeling als in hoofdstuk 2. Daarbij komt achtereenvolgens aan de orde:

- B2.1: omvang, ernst en gevolgen van psychische stoornissen op bevolkingsniveau (uitwerking van paragraaf 2.2). We gaan in op:

- omvang: de keuze voor de in dit themarapport gebruikte prevalentie- en incidentiecijfers;

- ernst: aannamen en beperkingen bij ziektelast;

- gevolgen: zorgkosten en kosten als gevolg van ziekteverzuim.

- B2.2: kenmerken van de aangeboden preventieve interventies (uitwerking van paragraaf 2.3):

- aard van de doelgroep: vergelijking van de indeling van preventie binnen de GGZ met die binnen de somatische gezondheidszorg;

- aanbiedingsvormen van preventieve interventies.

- B2.3: gezondheidseffecten op individueel niveau (uitwerking van paragraaf 2.4):

- wetenschappelijke bewijskracht van effectstudies;

- uitkomstmaten in de effectstudies.

\section{B2.1 Omvang, ernst en gevolgen op bevolkingsniveau (paragraaf 2.2)}

\section{Omvang}

Cijfers over de prevalentie en incidentie van psychische stoornissen in de Nederlandse bevolking worden verkregen uit epidemiologisch onderzoek. In dit rapport betreft het cijfers voor drie verschillende psychische stoornissen en drie verschillende leeftijdsgroepen. Er is in Nederland geen epidemiologisch onderzoek uitgevoerd waarin cijfers verkregen zijn voor al deze stoornissen en al deze leeftijdsgroepen. We maken dus gebruik van meerdere bronnen. De belangrijkste leidraad bij de keuze van die bronnen was dat de prevalentie- en incidentiecijfers zoveel mogelijk onderling vergelijkbaar zouden zijn.

Dit betekent ten eerste dat de definitie van psychische stoornissen tussen de verschillende bronnen overeenkomt. In dit themarapport gaan we uit van de definities volgens de DSM-IV (Diagnostic and Statistical Manual for mental disorders, fourth edition; APA, 2001), een classificatiesysteem dat specifiek gericht is op psychische stoornissen. Andere classificatiesystemen zijn de ICD (International Classification of Diseases) en de ICPC (International Classification of Primary Care), die voornamelijk gericht zijn op somatische ziekten, maar waarvan psychische en sociale problematiek ook een onderdeel vormen. Cijfers gebaseerd op de DSM-classificatie zijn niet zonder meer vergelijkbaar met cijfers gebaseerd op de ICPC-classificatie. De DSM-IV hanteert officiële internationale definities van psychische stoornissen, welke strenger en gedetail- 
leerder zijn dan die van de ICD en ICPC. De prevalentiecijfers van de laatste zullen daarom hoger uitvallen dan de prevalentiecijfers gebaseerd op de DSM.

Ten tweede is het gewenst dat de populatie waarop de cijfers gebaseerd zijn zoveel mogelijk overeenkomt tussen de bronnen. We gebruiken bij voorkeur cijfers die representatief zijn voor de gehele bevolking. Hoewel bijna alle Nederlanders ook binnen de huisartspopulatie vallen, zullen prevalentie- en incidentiecijfers van psychische stoornissen binnen de huisartspopulatie toch een ander beeld geven dan die van bevolkingsonderzoeken (Schoemaker et al., 2005). Daarom hebben we in dit themarapport geen gebruik gemaakt van de bestaande huisartsregistraties.

Ten derde moeten de cijfers een indicatie geven voor de Nederlandse populatie. Buitenlandse prevalentie- en incidentiecijfers van psychische stoornissen kunnen afwijken van de Nederlandse situatie, bijvoorbeeld door cultuurverschillen, genetische verschillen of verschillen in sociale omstandigheden.

Ten slotte gaat de voorkeur uit naar de meest recente cijfers. Normaal gesproken geldt voor epidemiologisch onderzoek dat de resultaten zo'n tien jaar up-to-date blijven omdat de prevalentie en incidentie van psychische stoornissen over het algemeen vrij stabiel is. Dit geldt echter niet voor alle stoornissen. Uit het Nemesis-onderzoek is bijvoorbeeld gebleken dat afhankelijkheid en misbruik van alcohol aan verandering in de tijd onderhevig is.

Samenvattend gebruiken we dus bij voorkeur cijfers die gebaseerd zijn op:

1. de DSM-classificatie;

2. bevolkingsonderzoek;

3. de Nederlandse populatie;

4. recent onderzoek, in elk geval minder dan 10 jaar oud.

Wanneer een databron niet aan alle bovenstaande criteria voldoet, vallen we terug op gegevens die aan zoveel mogelijk van de bovenstaande criteria voldoen. Daarbij baseren we de keuze van bronnen op de volgorde van de criteria zoals ze genoemd zijn; de eerstgenoemde criteria hebben dus meer prioriteit dan de laatstgenoemde.

De keuzes van databronnen die we hebben gemaakt voor elke leefijdsgroep en de argumentatie daarbij zijn hieronder beschreven.

\section{Prevalentie}

Prevalentiecijfers bij jongeren (13 t/m 17 jaar)

Prevalentiecijfers van depressie, angststoornissen en alcoholafhankelijkheid bij jongeren in de algemene bevolking zijn afkomstig van het onderzoek van Verhulst et al. (1997). Dit is een epidemiologisch onderzoek naar psychische stoornissen onder Nederlandse adolescenten van 13 tot en met 17 jaar. Hiervoor werd een landelijke steekproef getrokken. Onder andere werd de DIS (Diagnostic Interview Schedule) voor kinderen 
afgenomen. Stoornissen werden vastgesteld aan de hand van de DSM-III-R-criteria. Getrainde interviewers namen de interviews af. De diagnostische fase van het onderzoek had betrekking op 780 adolescenten en werd uitgevoerd tussen april en juni 1993. Dit onderzoek voldoet aan criterium $1 \mathrm{t} / \mathrm{m} 3$. Aan criterium 4 wordt niet voldaan: de studie is inmiddels twaalf jaar oud. Recentere gegevens die daarnaast ook aan de andere drie criteria voldoen zijn echter nog niet voorhanden.

In deze studie is de prevalentie vastgesteld via twee typen informanten: jongeren zelf en hun ouders. Beide verschaffen doorgaans een verschillende weergave van gedragsen emotionele problemen bij kinderen en jongeren. Dit heeft te maken met verschillen in perceptie van de problemen, verschillen in gedrag van de jongere in verschillende contexten en verschillen in de grens waarboven men bepaald gedrag als afwijkend zal rapporteren. Hoewel beide bronnen valide zijn en elkaar aanvullen presenteren we alleen prevalentiecijfers met de jongere zelf als informant. Deze sluiten volgens de auteur het beste aan bij de bronnen die voor volwassenen en ouderen zijn gebruikt. Bovendien komt deze keuze overeen met die van het Nationaal Kompas Volksgezondheid, waarin de cijfers over psychische stoornissen bij jongeren tevens zijn gebaseerd op de zelfrapportage van de jongeren. Voor de prevalentie van alcoholmisbruik bij jongeren zijn geen betrouwbare cijfers bekend.

\section{Volwassenen (18 t/m 64 jaar)}

Prevalentiecijfers van depressie, angststoornissen en alcoholmisbruik en -afhankelijkheid bij volwassenen zijn afkomstig van de Netherlands Mental Health Survey and Incidence Study (Nemesis; Bijl et al., 1997b; Vollebergh et al., 2003). Dit is een epidemiologisch onderzoek in de algemene bevolking van volwassenen van 18 tot en met 64 jaar. Het onderzoek was gebaseerd op een landelijke steekproef en maakte gebruik van DSM-III-Rcriteria. Hierbij werd in 1996 bij 7.076 personen een psychiatrisch interview afgenomen met behulp van de CIDI, een geactualiseerde versie van de DIS. Ook hier namen getrainde interviewers de interviews af. Op basis van de meting in 1996 konden prevalentiecijfers worden vastgesteld (Bijl et al., 1997a). Een tweede meting vond plaats in 1997-1998. Bij degenen die aan de eerste meting deelnamen is toen nogmaals een CIDI afgenomen. Van de 7.076 personen uit de eerste meting, werden 5.618 personen nogmaals geïnterviewd. Een derde meting vond plaats in 1999. Het onderzoek voldoet aan alle vier genoemde criteria.

\section{Ouderen (65 jaar en ouder)}

Prevalentiecijfers van depressie en angststoornissen bij ouderen zijn afkomstig uit de Longitudinal Aging Study Amsterdam (Lasa). Dit bevolkingsonderzoek werd in 1992/1993 uitgevoerd onder personen van 55-85 jaar (Beekman et al., 1995). Daarbij werden 3.056 ouderen in drie regio's gescreend. Bij 659 daarvan namen getrainde interviewers de DIS af. Hierop werd de prevalentie bepaald. Hierbij werden diagnosen gesteld op basis van de DSM-III. De selectie van respondenten waarbij de DIS afgenomen werd, bestond uit degenen die een score boven een drempelwaarde van de CES-D (Center for Epidemiologic Studies Depression Scale) hadden en een aselecte steekproef uit de groep die onder de drempelwaarde scoorde. De prevalentiecijfers zijn toegepast op de bevolkingsopbouw 
van 2003. De studie voldoet aan criterium 1, 2 en 3; aan criterium 4 wordt niet voldaan; de studie is meer dan tien jaar oud. Overigens is onlangs een nieuwe Lasa-studie gestart.

Voor de prevalentie van alcoholmisbruik en -afhankelijkheid hebben we gebruik gemaakt van de European Study of the Epidemiology of Mental Disorders (Esemed). Deze studie voldoet aan criterium 1, 2 en 4: gebaseerd op de DSM-classificatie, een onderzoek in de algemene bevolking, en een recent onderzoek dat in 2002 is uitgevoerd. Esemed is een Europese, cross-sectionele studie naar psychische stoornissen in de algemene, nietgeïnstitutionaliseerde bevolking, waarbij de epidemiologie van psychische stoornissen van zes Europese landen met elkaar wordt vergeleken: België, Frankrijk, Duitsland, Nederland, Spanje en het Verenigd Koninkrijk. De classificatie van psychische stoornissen is gebaseerd op de DSM-IV. Er worden 25.000 thuisinterviews van 90 minuten afgenomen, waarbij gebruik wordt gemaakt van de CIDI, de SF-36, de EuroQol 5D en delen van het WHO disablement Asessment Schedule II (WHO-DAS II). Ook het zorggebruik wordt geregistreerd.

\section{Incidentie}

Incidentiecijfers voor depressie, angststoornissen en alcoholmisbruik en -afhankelijkheid bij volwassenen zijn afkomstig uit Nemesis (Bijl et al., 2002). Voor jongeren en ouderen zijn geen rechtstreekse incidentiecijfers beschikbaar. Daarom zijn ze afgeleid van een grootschalig recent Amerikaans onderzoek naar de lifetime prevalentie en de leeftijdverdeling waarop psychische stoornissen voor het eerst ontstaan (Kessler et al., 2005). Het betreft de National Comorbidity Survey Replication, een onderzoek onder een landelijk representatieve steekproef van ruim 9 duizend (Engels sprekende) Amerikaanse volwassenen van 18 jaar en ouder. Daarbij zijn door professionele interviewers faceto-face interviews uitgevoerd op basis van de CIDI (Composite International Diagnostic Interview), een volledig gestructureerd interview waarmee psychiatrische diagnoses volgens de DSM-IV criteria worden vastgesteld. Het onderzoek is uitgevoerd tussen februari 2001 en april 2003.

Bij de leeftijdsverdeling van de eerste incidentie is uitgegaan van een lifetime risico van 75 jaar: het risico om vanaf de geboorte tot aan de leeftijd van 75 de betreffende stoornis voor het eerst te ontwikkelen. De leeftijdsverdeling is per stoornis weergegeven in percentielen.

Er is gebruik gemaakt van de bovengenoemde leeftijdsverdeling in percentielen in combinatie met de uit Nemesis bekende incidentiecijfers van volwassenen. Dit is als volgt gebeurd: Eerst is berekend welk percentage van de mensen met de betreffende stoornis deze volgens het Amerikaanse onderzoek voor het eerst heeft gekregen in de leeftijdsgroep volwassenen van 18 tot en met 64 jaar. De aanname is dat dit percentage overeenkomt met het aantal incidente gevallen zoals die volgens Nemesis jaarlijks in Nederland voorkomen bij volwassenen. Door de verhouding tussen het Amerikaanse incidentiepercentage en het Nederlandse incidentie-aantal toe te passen op de leeftijdsgroepen jongeren en ouderen kan het aantal incidente gevallen in deze leeftijdsgroepen geschat worden. 
Concreet is de incidentieberekening per stoornis als volgt voor jongeren:

- Depressie: volgens het Amerikaanse onderzoek is het percentage jongeren met een eerste depressie 13,4\%; het percentage volwassenen met eerste depressie is volgens dit onderzoek $76,0 \%$. Volgens Nemesis is het aantal volwassenen met een eerste depressie 288.600. Het aantal incidente gevallen van depressie in de leeftijdsgroep jongeren wordt daarmee geschat op 288.600/76,0x13,4; dit is ongeveer 50.900 .

- Angst: volgens het Amerikaanse onderzoek is het percentage jongeren met een eerste angststoornis $14,0 \%$; het percentage volwassenen met eerste angststoornis is $35,6 \%$. Het aantal volwassenen met een eerste angststoornis is volgens Nemesis 322.000 . Het aantal incidente gevallen van angststoornis in de leeftijdsgroep jongeren wordt daarmee geschat op 322.000/35,6×14,0; dit is ongeveer 126.600 .

- Alcoholmisbruik: volgens het Amerikaanse onderzoek is het percentage jongeren met een eerste incidentie van alcoholmisbruik 14,3\%; het percentage volwassenen met een eerste incidentie van alcoholmisbruik is $67,4 \%$. Het aantal volwassenen met een eerste incidentie van alcoholmisbruik is 260.900 . Het aantal incidente gevallen van alcoholmisbruik in de leeftijdsgroep jongeren wordt daarmee geschat op 260.900/67,4x14,3; dit is ongeveer 55.400 .

- Alcoholafhankelijkheid: volgens het Amerikaanse onderzoek is het percentage jongeren met een eerste incidentie van alcoholafhankelijkheid 7,9\%; het percentage volwassenen hiermee is $79,4 \%$. Het aantal volwassenen met een eerste incidentie van alcoholafhankelijkheid is 50.700. Daarmee wordt het aantal incidente gevallen van alcoholafhankelijkheid in de leeftijdsgroep jongeren geschat op 50.700/79,4x7,9; dit is ongeveer 5.000 .

- Alcoholmisbruik of -afhankelijkheid: Volgens Nemesis is het aantal incidente gevallen van alcoholmisbruik of -afhankelijkheid 70\% van de optelsom van alcoholmisbruik en alcoholafhankelijkheid. Deze verhouding is ook bij jongeren toegepast, waarmee de incidentie geschat wordt op 70\% van $55.400+5.000$; dit is ongeveer 42.300 .

Voor ouderen is de incidentieberekening per stoornis als volgt:

- Depressie: volgens het Amerikaanse onderzoek is het percentage ouderen van 65 jaar tot en met 75 jaar met een eerste depressie 5,0\%; het percentage volwassenen 18-64 jaar met eerste depressie is volgens dit onderzoek 76,0\%. Het aantal volwassenen met een eerste depressie is volgens Nemesis 288.600. Het aantal incidente gevallen van depressie in de leeftijdsgroep ouderen wordt daarmee geschat op 288.600/76,0x5,0; dit is ongeveer 19.000 .

- Angststoornissen: volgens het Amerikaanse onderzoek is het percentage ouderen met een eerste angststoornis 1,6\%; het percentage volwassenen met eerste angststoornis is $35,6 \%$. Het aantal volwassenen met een eerste angststoornis is volgens Nemesis 322.000. Het aantal incidente gevallen van angststoornis in de leeftijdsgroep ouderen wordt daarmee geschat op 322.000/35,6x1,6; dit is ongeveer 14.500 .

- Alcoholmisbruik: volgens het Amerikaanse onderzoek is het percentage ouderen met een eerste incidentie van alcoholmisbruik 14,3\%; het percentage volwassenen met een eerste incidentie van alcoholmisbruik is $67,4 \%$. Het aantal volwassenen met een eerste incidentie van alcoholmisbruik is 260.900 . Het aantal incidente gevallen van alcohol- 
misbruik in de leeftijdsgroep ouderen wordt daarmee geschat op 260.900/67,4x14,3; dit is ongeveer 55.400 .

- Alcoholafhankelijkheid: volgens het Amerikaanse onderzoek is het percentage ouderen met een eerste incidentie van alcoholafhankelijkheid 16,5\%; het percentage volwassenen met een eerste incidentie van alcoholafhankelijkheid is $79,4 \%$. Het aantal volwassenen met een eerste incidentie van alcoholafhankelijkheid is 50.700 . Het aantal incidente gevallen van alcoholafhankelijkheid in de leeftijdsgroep ouderen wordt daarmee geschat op 50.700/79,4x16,5; dit is ongeveer 10.500 .

- Alcoholmisbruik of -afhankelijkheid: Volgens Nemesis is het aantal incidente gevallen van alcoholmisbruik of -afhankelijkheid 70\% van de optelsom van alcoholmisbruik en alcoholafhankelijkheid. Deze verhouding is ook bij ouderen toegepast, waarmee de incidentie geschat wordt op $70 \%$ van $55.400+10.500$; dit is ongeveer 46.100 .

De Amerikaanse studie geeft geen informatie over de eerste incidentie van stoornissen bij ouderen ouder dan 75 jaar.

Alle prevalentie- en incidentiecijfers zijn toegepast op de opbouw van de Nederlandse bevolking in het referentiejaar 2003. In enkele gevallen zijn vanuit de bronstudie geen jaarprevalenties gepubliceerd, maar 1-maands- of 6-maandsprevalenties. Dit geldt met name voor de prevalentie van depressie en angststoornissen bij ouderen uit Lasa, en van depressie, angst en alcoholafhankelijkheid bij jongeren uit de studie van Verhulst et al. (1997). Ten behoeve van dit themarapport zijn deze cijfers omgerekend naar jaarprevalenties. Dit hebben we gedaan door de verhoudingsfactor tussen de 6-maandsprevalentie en jaarprevalentie zoals die bekend is uit Nemesis toe te passen bij de cijfers van jongeren en ouderen. Nemesis heeft namelijk zowel 6-maands- als jaarprevalenties van de onderzochte psychische stoornissen gepubliceerd.

\section{Ernst}

De ziektelast is weergegeven in DALY's, een afkorting van Disability-Adjusted Life-Years. De berekening hiervan is weergegeven in tekstblok 1.1. Bij de berekening van de ziektelast zijn enkele aannamen gemaakt:

- Bij de DALY-berekening van het aantal verloren levensjaren is geen rekening gehouden met sterfte door suïcide. Binnen de ziektelaststudies wordt suïcide namelijk als een aparte stoornis beschouwd.

- Bij de berekening van ziektejaarequivalenten van de psychische stoornissen is de wegingsfactor voor de drie leeftijdsgroepen gelijk. De aanname is dus dat de drie leeftijdsgroepen niet van elkaar verschillen voor wat betreft de ernst van de stoornissen.

Bovendien zijn er enkele beperkingen verbonden aan de gepresenteerde ziektelastcijfers. Deze presenteren we hieronder per stoornis.

- Depressie: Het aantal verloren levensjaren is gebaseerd op depressie in engere zin en dysthymie. Dit omdat de ICD-10 classificatie waarop de berekening is gebaseerd geen onderscheid maakt tussen deze stoornissen.

- Angststoornissen: Het aantal DALY's bij angststoornissen is een onderschatting van de werkelijkheid. Er is geen rekening gehouden met het feit dat veel mensen meer 
dan één angststoornis tegelijkertijd hebben. Bij deze mensen zal de kwaliteit van leven hoogstwaarschijnlijk lager zijn dan bij degenen die 'slechts' één angststoornis hebben.

- Alcoholafhankelijkheid en -misbruik: Bij de leeftijdsgroep jongeren zijn de DALY's voor alcoholafhankelijkheid en -misbruik alleen berekend op basis van de wegingsfactor voor alcoholafhankelijkheid. De reden hiervoor is dat er geen prevalentiecijfer bekend is voor alcoholmisbruik bij jongeren. Dit betekent dat het gepresenteerde aantal DALY's voor jongeren een onderschatting is van het werkelijke aantal DALY's. Bij volwassenen zijn de DALY's afzonderlijk voor alcoholmisbruik en voor alcoholafhankelijkheid berekend, omdat de wegingsfactor voor beide stoornissen verschilt. Vervolgens zijn de DALY’s voor misbruik en afhankelijkheid bij elkaar opgeteld.

\section{Gevolgen}

De gevolgen van psychische stoornissen zijn in dit themarapport weergegeven in economische kosten, (kosten ten gevolge van) ziekteverzuim en arbeidsongeschiktheid. Hieronder geven we aan welke bronnen we hiervoor gebruikt hebben (zie ook tekstblok 2.1 en bijlage 6).

\section{Kosten}

Voor het berekenen van de kosten van psychische stoornissen hebben we gebruik gemaakt van bronnen voor directe medische kosten en voor indirecte kosten door productieverlies als gevolg van ziekteverzuim. Directe medische kosten - oftewel directe zorgkosten - zijn kosten gemaakt voor preventie, diagnostiek, behandeling, verpleging en verzorging van de stoornis.

Voor directe medische kosten gebruiken we gegevens die afkomstig zijn uit de studie 'Kosten van Ziekten in Nederland 2003' (Slobbe et al., 2006). Hierin wordt voor het referentiejaar 2003 beschreven waaraan het geld dat beschikbaar is voor de gezondheidszorg wordt uitgegeven. Voor een uitgebreide beschrijving van de methodologie bij deze studie verwijzen we naar de betreffende website: www.kostenvanziekten.nl., tekstblok 2.1 en bijlage 6 .

De indeling van zorggebruik naar diagnose volgens de ICD-9 heeft tot gevolg dat er geen aparte kosten berekend zijn voor depressie in engere zin, maar voor depressie en dysthymie samen. Bovendien zijn er geen aparte kosten berekend voor alcoholmisbruik en -afhankelijkheid, omdat deze bij de ICD-9 samen genomen worden met misbruik en -afhankelijkheid van drugs. De cijfers geven dus een overschatting van de kosten voor depressie in engere zin en voor alcoholmisbruik en -afhankelijkheid.

Voor kosten via productieverlies door ziekteverzuim gebruiken we gegevens van het Trimbos-instituut (Smit et al., in druk-b). Deze zijn gegenereerd uit gegevens van 5.504 mensen uit Nemesis (zie 'prevalentie volwassenen'). Binnen Nemesis is onderzoek gedaan naar de rol die psychische stoornissen spelen in het ontstaan, beloop en frequentie van ziekteverzuim. De gegevens zijn gebaseerd op alle respondenten uit Nemesis, ongeacht of ze wel of geen baan hadden en uit hoeveel uren deze baan bestond. Gegevens over psy- 
chische problemen en ziekteverzuim werden op elke meting verzameld; de resultaten waarover gerapporteerd is betreffen alleen de eerste meting. De gegevens zijn zodanig gewogen dat ze te generaliseren zijn naar de gehele bevolking in Nederland. Het aantal respondenten met een betaalde baan bij de eerste meting was 4.783. Alle bedrijfstakken en beroepsgroepen waren in het onderzoek vertegenwoordigd.

Deze laatste berekeningen zijn uitgevoerd via een bottom-up aanpak. Dit houdt in dat de medische consumptie en ziekteverzuimdagen van mensen met een psychiatrische diagnose worden gemeten vanuitbevolkingsonderzoek. Vervolgensworden demedischeconsumptie en de ziekteverzuimdagen in kosten vertaald, waarbij de ziekteverzuimdagen worden uitgedrukt in productiviteitsverliezen ten gevolge van de stoornis. Voor het inschatten van productieverliezen is de 'menselijke kapitaalmethode' gebruikt. De ziekteverzuimdagen werden evenredig verdeeld over de werkdagen (productieverlies door niet werken) en vrije dagen (productieverlies door het niet kunnen uitvoeren van huishoudelijke taken). Voor het berekenen van de kosten van een verzuimde werkdag is een leeftijds- en sexe-specifieke economische tegenwaarde gebruikt van de productie die anders geleverd zou zijn. De kosten door het niet kunnen uitvoeren van huishoudelijke taken zijn gebaseerd op de kosten voor een zwart-betaalde huishoudelijke hulp $(8,30$ euro per uur). Deze kosten kunnen worden gerelateerd aan de verschillende psychiatrische diagnoses, omdat per diagnose bekend is hoe groot de medische consumptie en het aantal ziekteverzuimdagen is (Smit et al., in druk-b). Bij de kostenberekening is eveneens uitgegaan van de kosten voor het refrentiejaarjaar 2003. De kostenberekening komt overeen met de meest recente Nederlandse richtlijn voor gezondheidseconomische evaluaties.

We hebben in de economische doorrekening in bijlage 6 ook rekening gehouden met de directe niet-medische kosten: bijvoorbeeld reiskosten die een patiënt maakt, en de kosten die vrienden en familie voor informele zorg van een zieke maken. Deze zijn niet opgenomen in de bovengenoemde kosten van ziekten-studie van Slobbe et al. (2006). Deze kosten zullen overigens over het algemeen laag zijn in verhouding tot de directe medische en de indirecte kosten.

\section{Ziekteverzuim}

In dit themarapport gaan we alleen in op (kosten ten gevolge van productieverlies door) ziekteverzuim bij volwassenen. Gegevens over ziekteverzuim bij jongeren en ouderen blijven buiten beschouwing. Bij jongeren zal ziekteverzuim voornamelijk schoolverzuim betreffen. Hierover zijn geen gegevens bekend. Ziekteverzuim bij ouderen $>65$ jaar is niet of nauwelijks aan de orde, omdat zij over het algemeen niet meer deelnemen aan het arbeidsproces.

\section{Arbeidsongeschiktheid}

Als maat voor arbeidsongeschiktheid gebruiken we het aantal lopende en nieuwe arbeidsongeschiktheidsuitkeringen dat toegekend is aan mensen met de betreffende psychische stoornis (UWV, 2002). De registratie van het UWV biedt zicht op het aantal nieuwe, bestaande en beëindigde uitkeringen dat in 2002 is toegekend. Het betreft 
een optelsom van uitkeringen uit de Wet op de arbeidsongeschiktheidverzekering (WAO), de Wet Arbeidsongeschiktheidverzekering zelfstandigen (WAZ) en de Wet arbeidsongeschiktheidvoorziening jong-gehandicapten (Wajong). De medische diagnosecodes - de zogenaamde CAS-codes - worden ingevuld door de verzekeringsartsen die de beoordeling doen van de cliënten. De classificatie van ziekten is gebaseerd op de ICD-10. In de registratie is het aantal uitkeringen per ziektediagnose weergegeven. Omdat het UWV alleen voor het jaar 2002 de aantallen heeft uitgesplitst naar diagnose, maken we gebruik van deze cijfers, die waarschijnlijk niet al te veel zullen afwijken van die uit 2003.

Aan de registratie van het UWV kleeft een aantal beperkingen. Ten eerste is het aantal geregistreerde mensen met een arbeidsongeschiktheidsdiagnose door psychische stoornissen een onderschatting van het werkelijke aantal. Een deel van de mensen die arbeidsongeschikt zijn verklaard op grond van een somatische diagnose heeft daarnaast ook een depressie. Deze comorbide depressie wordt niet geregistreerd. Ten tweede zijn de diagnosegroepen voor psychische stoornissen gebaseerd op de ICD-10 classificatie, dus niet op de door ons gehanteerde DSM classificatie. De cijfers sluiten daardoor niet geheel aan op onze doelgroep. Ten slotte wordt een leeftijdsindeling gehanteerd die niet geheel overeenkomt met de indeling binnen dit themarapport. De leeftijdsgroep die wij in het themarapport hanteren voor volwassenen is 18 tot en met 64 jaar. Bij de registratie van arbeidsongeschiktheidsuitkeringen ligt de natuurlijke ondergrens bij de leeftijd van 16 jaar, omdat jongeren vanaf die leeftijd niet meer leerplichtig zijn en tot de beroepsbevolking kunnen behoren. De groep arbeidsongeschikten die jonger is dan 18 jaar zal echter klein zijn, omdat een groot deel van die leeftijdsgroep nog geen betaalde arbeid verricht. De natuurlijke bovengrens bij de arbeidsongeschiktheidsregistratie is 65 jaar, omdat 65plussers in principe niet meer tot de beroepsbevolking behoren; deze leeftijdsgrens valt daarmee samen met onze bovengrens.

Omdat we in het doorrekenen van de effecten van preventieve interventies een tijdshorzion hanteren van maximaal één jaar, hebben we daarbij wel ziekteverzuim, maar niet arbeidsongschiktheid meegenomen (bijlage 6).

\section{B2.2 Kenmerken van de aangeboden preventieve interventies (paragraaf 2.3)}

\section{Aard van de doelgroep: Indeling preventie in de GGZ versus preventie in de somatische gezondheidszorg}

De preventieve interventies die we in dit themarapport beschrijven zijn ingedeeld naar de doelgroep waarop zij zich richten (zie ook Mrazek \& Haggerty, 1994): universele, selectieve en geïndiceerde preventie. Deze indeling is gebruikelijk in de geestelijke gezondheidszorg, maar wordt niet gehanteerd in de somatische gezondheidszorg. Daar is het gebruikelijk om preventie in te delen in primaire, secundaire en tertiaire preventie. Ook deze indeling is weliswaar gebaseerd op doelgroepen, maar die zijn niet helemaal vergelijkbaar met de doelgroepen uit de GGZ-preventie. Binnen de GGZ-preventie is er sprake van doelgroepen die zich in een continuüm tussen ziek en niet-ziek bevinden, ter- 
wijl bij preventie in de somatische gezondheidszorg alleen onderscheid wordt gemaakt tussen wel ziek of niet ziek. De GGZ-indeling en de 'somatische' indeling van preventie zijn in tabel 2.1 ter vergelijking naast elkaar gezet.

Onder primaire preventie vallen activiteiten die voorkomen dat een bepaald gezondheidsprobleem, ziekte of ongeval ontstaat (Witte, 2006). De doelgroep bij primaire preventie is de gezonde populatie. Op dit aspect komt primaire preventie overeen met universele preventie. Bij secundaire preventie worden ziekten of afwijkingen in een vroeg stadium opgespoord. De ziekte of afwijking kan daardoor eerder worden behandeld, zodat de zieke eerder geneest of de ziekte niet erger wordt. De doelgroep bestaat uit personen die een verhoogd risico of een bepaalde genetische aanleg hebben, of personen die ziek zijn. De ziekte is bij deze personen echter nog niet vastgesteld. De doelgroep van secundaire preventie omvat daarmee onder andere de doelgroep voor zowel selectieve als geïndiceerde preventie. Bij tertiaire preventie (zorg) worden complicaties en ziekteverergering voorkomen door tekorten in de gezondheidstoestand of te heffen, te reduceren of te compenseren. De interventie is dus niet gericht op preventie van de ziekte zelf, maar op het voorkomen van de daaruit voortvloeiende complicaties. De doelgroep van tertiaire preventie betreft dus mensen met een ziekte. Tertiaire preventie valt daarmee buiten de focus van universele, selectieve en geïndiceerde preventie.

\section{Aanbiedingsvormen van preventieve interventies}

In paragraaf 2.3 gaven we aan dat psychologische interventies gericht op selectieve en geïndiceerde preventie op verschillende manieren aangeboden kunnen worden: via een groepscursus, lotgenotencontact of zelfhulpcursussen, waaronder de internetcursus. Hieronder volgt een beschrijving van deze aanbiedingsvormen.

- Een groepscursus is momenteel de meest gangbare aanbiedingsvorm. Onder professionele begeleiding komen groepen van circa tien personen bijeen. In een beperkt aantal sessies, meestal tussen de acht en de twaalf, ontvangen de cursisten gerichte psycho-educatie, een lichte vorm van cognitieve gedragstherapie, ontspanningsoefeningen, en krijgen scholing in symptoomherkenning, en terugvalpreventie.

- Lotgenotencontact is gericht op het bieden van een luisterend oor, het ondernemen van plezierige activiteiten, en is vooral steunend bedoeld. Een voorbeeld hiervan is de selectieve interventie ‘Bezoekdiensten van weduwen voor weduwen’ (zie paragraaf 3.5.1). De bezoekende weduwe heeft eerst een training ontvangen en onderhoudt vervolgens contact met een lotgenoot.

- Bij een zelfhulpcursus gaat de persoon zelf aan de slag, bijvoorbeeld met een zelfhulpboek. De deelnemers wordt een gestandaardiseerde psychologische behandeling aangeboden die de betrokkene zelfstandig - eventueel met beperkte (telefonische) begeleiding van een GGZ-hulpverlener - kan uitvoeren. Het zelfhulpboek kan een opbouw volgen die ingegeven wordt door gedragstherapeutische inzichten, en biedt de cursist instructies en oefeningen. In plaats van zelfhulpboeken kan er ook gewerkt worden met andere media zoals video's, CDs en interactieve computerprogramma's.

- Een specifieke vorm van zelfhulpcursus is de internetcursus. Internetcursussen lijken op de eerder genoemde zelfhulpcursussen en zijn daar dikwijls van afgeleid. Het zijn 
gestructureerde, op therapeutische inzichten gebaseerde, cursussen die stap voor stap worden aangeboden via het internet. De cursist kan anoniem, op zelf gekozen tijdstippen, en in een zelf gekozen tempo aan de slag. Dat maakt deze werkvorm laagdrempelig en voor veel mensen acceptabel. Daardoor kunnen grote groepen op een laagdrempelige manier bereikt worden met preventie. De internetcursus kan geheel geautomatiseerd en interactief zijn, en wordt dan aangeboden zonder rechtstreekse medewerking van een professional. Professionele begeleiding kan ook gecombineerd worden met de internetinterventie, bijvoorbeeld via e-mail, of via groepsbijeenkomsten in aanvulling op de internetinterventie. Dergelijke mogelijkheden zullen in de toekomst verder worden uitgewerkt.

Eenzelfde cursus kan in verschillende varianten worden aangeboden, dus zowel als groepscursus, als zelfhulpcursus en als internetcursus. Afhankelijk van de doelgroep kan de meest geschikte aanbiedingsvorm ingezet worden.

\section{B2.3 Gezondheidseffecten op individueel niveau (paragraaf 2.4)}

\section{Wetenschappelijke bewijskracht van effectstudies}

In paragraaf 2.4 is een indeling gegeven voor de sterkte van het wetenschappelijk bewijs voor de effectiviteit van preventieve interventies. Deze indeling is gebaseerd op de criteria zoals die gevolgd werden in de Multidisciplinaire GGZ-Richtlijnen (Landelijke Stuurgroep Multidisciplinaire Richtlijnontwikkeling in de GGZ, 2005). De bewijskracht loopt op van minimaal één ster naar maximaal vier sterren. Het hoogste niveau van bewijskracht (vier sterren) wordt in dit rapport niet gegeven, en slechts één interventie (de groepscursus 'In de put, uit de put', paragraaf 3.4.2) krijgt drie sterren. Daar zijn enkele redenen voor. Ten eerste is preventie van psychische stoornissen historisch gezien een jonge discipline waardoor de opbouw van de evidence-base nog maar net begonnen is. Ten tweede kunnen psychologische interventies niet dubbelblind worden aangeboden, waardoor studies die beantwoorden aan het A2-criterium niet voorkomen in dit vakgebied. Ten derde zijn belangrijke financiers voor zorgonderzoek met hun uitgesproken voorkeur voor vernieuwend onderzoek zelden geïnteresseerd in de financiering van replicatieonderzoek. Daarom komt het nauwelijks voor dat twee (of meer) gerandomiseerde studies uitgevoerd werden naar de effectiviteit van eenzelfde interventie in Nederland. Dit maakt het vervolgens moeilijk om op basis van het A1criterium een vier sterren kwalificatie te behalen. Ten slotte zijn preventietrials waarbij naar het effect van de interventie op de incidentie wordt gekeken zeldzaam, omdat deze studies grote steekproeven vergen. Dat maakt dit type studie duur. De beoordeling van de bewijskracht dient daarom beschouwd te worden in de context van deze factoren.

\section{Uitkomstmaten in de effectstudies}

In dit rapport onderscheiden we drie soorten stoornisspecifieke uitkomstmaten: reductie van de incidentie, reductie van het risico dat iemand een stoornis ontwikkelt (verandering in risicostatus) en reductie van het aantal stoornisspecifieke klachten. 
- Reductie van de incidentie. Onder invloed van de interventie, en in vergelijking tot een controlegroep, neemt het aantal nieuwe gevallen van de betreffende stoornis af. Met gerandomiseerd effectonderzoek naar veranderingen in incidentie wordt dus rechtstreeks bewijs geleverd voor het effect van de interventie op het ontstaan van nieuwe stoornissen. Voor dit soort studies is het nodig om een diagnose vast te stellen om zo na te gaan wie de stoornis wel of niet gekregen heeft. Dergelijke studies worden zelden uitgevoerd omdat zij grote steekproeven vergen en dus duur zijn.

- Verandering in de risicostatus. Onder invloed van de interventie, en in vergelijking tot een controlegroep, neemt het aantal personen met een ongunstige risicostatus af. Een ongunstige risicostatus correspondeert met een mild beeld (subklinisch, prodromaal) dat aan een psychische stoornis vooraf kan gaan. Het verliezen van een risicostatus is gunstig, omdat dit de kans verkleint dat deze persoon alsnog de betreffende stoornis ontwikkelt. Voor depressie en voor alcoholmisbruik en -afhankelijkheid worden normatieve grenzen voor een ongunstige risicostatus in de literatuur genoemd. Deze worden meestal gebruikt in preventieonderzoek met risicostatus als uitkomstmaat.

- Reductie van het aantal klachten. In gerandomiseerde effectstudies van preventieve interventies wordt dikwijls de reductie in het aantal stoornisspecifieke klachten (symptomen) als primaire uitkomstmaat genomen. De redenering daarbij is als volgt. Wanneer onder invloed van de interventie, en in vergelijking tot een controlegroep, het aantal klachten afneemt dan zal bij de betreffende personen ook de kans op het ontwikkelen van de stoornis afnemen. Hierbij dient bedacht te worden dat bij iemand de klachten weliswaar zijn afgenomen, maar de persoon in kwestie kan nog steeds een ongunstige risicostatus hebben, ofwel boven een veilige grens zitten. Deze uitkomstmaat geeft dus het minste zekerheid over de behaalde gezondheidswinst: er kan alleen geconstateerd worden dat er sprake is van een verlichting van klachten.

We vinden het bewijs sterker wanneer de primaire uitkomstmaat betrekking heeft op de incidentie van betreffende stoornis, minder sterk wanneer deze betrekking heeft op risicostatus, terwijl klachtenreductie de minste zeggingskracht heeft. 


\section{BIJLAGE 3 INTERVENTIES GERICHT OP DE PREVENTIE VAN DEPRESSIE}

In hoofdstuk 3 worden de in Nederland beschikbare preventieve interventies kort beschreven. De nadruk ligt daar op het onderzoek naar de effectiviteit van de interventies. In deze bijlage geven we een uitgebreider beschrijving van de interventies, met meer aandacht voor de inhoud van de interventie, het aanbod en het bereik. Voor iedere interventie gaan we achtereenvolgens in op de doelgroep, het doel, de methode, aanbod en bereik, de ontwikkelingsfase en de wetenschappelijke status.

In dit overzicht wordt de indeling in het hoofdstuk gevolgd. De interventies worden per leeftijdsgroep beschreven: eerst voor jongeren, vervolgens voor volwassenen en ten slotte voor ouderen. Per leeftijdsgroep komen achtereenvolgens de universele, selectieve en geïndiceerde preventieve interventies aan bod. De indeling naar ontwikkelingsfase (G, I of B) staat beschreven in paragraaf 2.3. De wetenschappelijke status $\left({ }^{*},{ }^{* *}\right.$ of $\left.{ }^{* * *}\right)$ en de gehanteerde uitkomstmaat (I, $\mathrm{R}$ of $\mathrm{K}$ ) worden beschreven in paragraaf 2.4.

\section{Preventieve interventies voor jongeren}

Tabel 3.2 in paragraaf 3.3.1 biedt een overzicht van de in Nederland beschikbare interventies ter preventie van depressie bij jongeren.

\section{Universele preventie van depressie bij jongeren}

\section{Lesprogramma 'Levensvaardigheden' (GGD Rotterdam)}

Dit programma is onder andere gebaseerd op het programma 'Life Skills' van de WHO.

- Doelgroep: Alle leerlingen in de derde klas van het voortgezet onderwijs.

- Doel: Adolescenten positiever over zichzelf laten denken, hun gevoelens van spanning bij het uiten van negatieve emoties verminderen, en sociale en emotionele vaardigheden stimuleren.

- Methode: Veertien lessen van vijftig minuten, gegeven door docenten. Het programma is opgebouwd langs de lijnen van het 4G-model: gebeurtenis (G1) + gedachten (G2) = gevoel (G3) + gedrag (G4). Na de introductieles worden vier lessen besteed aan het aanleren van de vier G's. Daarna worden vaardigheden behandeld die gekoppeld zijn aan thema's als genotmiddelen en gokken, omgaan met conflicten, pesten en seksualiteit. Er wordt gewerkt met videobeelden, rollenspelen en gedragsafspraken.

- Ontwikkelingsfase: G.

- Aanbod en bereik: In Rotterdam wordt het programma nu op helft van de scholen voor het voortgezet onderwijs en in enkele buitenschoolse settingen uitgevoerd. In november 2006 worden ook docenten van scholen in Den Haag getraind. Het NIGZ is dit jaar gestart met een landelijke verspreiding van het programma.

- Wetenschappelijke status: ${ }^{*}$. Er zijn aanwijzingen dat het programma effecten heeft op intermediaire uitkomstmaten, zoals 'zelfwaardering', 'ervaren spanning bij het adequaat uiten van negatieve emoties', 'de intentie om sociale en emotionele vaardigheden te gebruiken' en 'de relatie met klasgenoten' (Gravesteijn et al., 2004). Het is niet bekend of dit programma effecten heeft op het ontstaan van depressie. 
- Doelgroep: Leerlingen tussen 12-18 jaar van het Voortgezet Onderwijs. Er zijn twee programma's: voor jongeren tussen 12-14 jaar en voor jongeren tussen 14-18 jaar. Daarvan zijn er twee verschillende versies: één voor HAVO en VWO, en één voor VMBO/IWOO/SVO.

- Doel: Jongeren stimuleren tot een gezonde ontwikkeling en daarmee het voorkomen van ongewenst gedrag.

- Methode: Gedurende tien lessen wordt in de klas met vaardigheden geoefend. De oefeningen richten zich op de volgende thema's: vrienden maken en houden, rekening houden met elkaar, luisteren, zeggen wat je voelt, omgaan met pesten en groepsdruk, 'nee' zeggen, weten waar je goed in bent, complimenten geven, omgaan met mensen thuis, weten wat je belangrijk vindt, keuzes maken, nadenken over risico's van gokken, en middelengebruik.

- Ontwikkelingsfase: G.

- Aanbod en bereik: Onbekend is hoe vaak dit lesprogramma wordt gebruikt. Scholen kunnen dit programma zelf aanschaffen.

- Wetenschappelijke status: * In het buitenland is in beperkte mate onderzoek naar dit programma gedaan, maar het is niet bekend of dit ook effecten heeft op het ontstaan van depressie.

\section{Selectieve preventie van depressie bij jongeren}

Groepscursus ‘KOPP-groep: Kinderen van Ouders met Psychische Problemen' (Bool et al., 2005, Factsheet Trimbos-instituut, 2001)

- Doelgroep: Jongeren 12-15 jaar, waarvan één of beide ouders psychische dan wel verslavingsproblemen hebben. De jongeren lopen hierdoor zelf een verhoogd risico op psychische klachten, waaronder depressie.

- Doel: Voorkomen van psychische problemen als mogelijk gevolg van de situatie waarin de kinderen opgroeien.

- Methode: De cursus bestaat uit acht wekelijkse bijeenkomsten van ongeveer anderhalf uur en een terugkombijeenkomst. Daarnaast worden twee bijeenkomsten met de ouders georganiseerd. Tijdens de cursus wordt ingegaan op de thuissituatie, vindt kennisoverdracht plaats en worden competentie verhogende vaardigheden aangeleerd om beter om te kunnen gaan met de problemen in de thuissituatie.

- Ontwikkelingsfase: G.

- Aanbod en bereik: Deze cursus wordt door 90\% van de 54 GGZ-preventieafdelingen uitgevoerd.

- Wetenschappelijke status: *. Uit gerandomiseerd onderzoek (Beardslee et al., 2003) blijkt dat de interventie wel effecten heeft op risico- en beschermende factoren, maar niet op depressiviteitsklachten bij de kinderen.

Groepscursus KOPP 16+ (Bool et al., 2005, Factsheet Trimbos-instituut, 2001)

- Doelgroep: Jongeren tussen 16 en 25 jaar waarvan één of beide ouders psychische dan wel verslavingsproblemen hebben.

- Doel: Voorkomen van psychische problemen als mogelijk gevolg van de situatie waarin de jongeren opgroeien.

- Methode: De cursus bestaat uit acht wekelijkse bijeenkomsten van ongeveer anderhalf uur en een terugkombijeenkomst. Tijdens de cursus wordt ingegaan op de thuissituatie en worden vaardigheden aangeleerd om beter om te kunnen gaan met de problemen in de thuissituatie; de beschermende factoren worden versterkt.

- Ontwikkelingsfase: G.

- Aanbod en bereik: Deze cursus wordt door zo'n 50\% van de 54 GGZ-preventieafdelingen uitgevoerd.

- Wetenschappelijke status: *. 
- Doelgroep: Gezinnen waarin één of beide ouders een psychiatrisch probleem heeft met tenminste één kind tussen 8-14 jaar.

- Doel: Voorkomen dat kinderen zelf psychische problemen ontwikkelen.

- Methode: Verhogen van de veerkracht bij de kinderen, verruimen van begrip voor de ziekte binnen het gezin, geven van psycho-educatieve informatie onder andere over voortekenen van depressie bij kinderen. De cursus bestaat uit zeven bijeenkomsten, waaronder een gezinsgesprek en een follow-up bijeenkomst.

- Ontwikkelingsfase: G.

- Aanbod en bereik: Jeugd- en volwassen afdelingen van GGZ-instellingen voeren deze groepscursus uit, maar het is onbekend hoeveel dat er zijn.

- Wetenschappelijke status: * Er is in het buitenland een gerandomiseerd onderzoek uitgevoerd waarin deeffecten van deze interventie werden vergeleken met tweeinformatiebijeenkomsten voor ouders (Beardslee et al., 2003). Daaruit blijkt dat de interventie wel effecten heeft op risicoen beschermende factoren, maar niet op depressiviteitsklachten bij de jongeren.

\section{Geïndiceerde preventie van depressie bij jongeren}

\section{Groepscursus 'Een stap op weg' (Pauw et al., 1999)}

Deze cursus is gebaseerd op de 'Coping with depression course for adolescents' van Clarke et al. (1990).

- Doelgroep: Jongeren van 14 - 18 jaar met milde depressiviteitsklachten en minimaal VMBO theoretische leergang (MAVO).

- Doel: Verminderen van de klachten en het voorkomen van verergering door het vergroten van inzicht in de eigen klachten en het aanleren van vaardigheden om hier beter mee om te gaan.

- Methode: De cursus bestaat uit tien bijeenkomsten van elk twee uur en een terugkombijeenkomst. Tijdens de cursus wordt aandacht besteed aan de relatie tussen denken, doen en voelen, het doorbreken van negatieve gedachten, het vermeerderen van plezierige activiteiten en het versterken van sociale vaardigheden.

- Ontwikkelingsfase: G.

- Aanbod en bereik: Meerdere preventieafdelingen bieden deze cursus aan, maar exacte cijfers ontbreken. Over het algemeen is de ervaring dat het moeilijk is om de doelgroep te werven voor een groepsaanbod.

- Wetenschappelijke status: **. De cursus is in de Verenigde Staten effectief bevonden (Clarke et al., 1995, 2001), maar de ingekorte Nederlandse versie is nog niet (voldoende) onderzocht op effectiviteit.

Groepscursus 'Grip op je dip: zelf je somberheid overwinnen' (Voordouw et al., 2002a)

Ook deze cursus is gebaseerd op de Amerikaanse 'Coping with depression course for adolescents' van Clarke et al. (1990).

- Doelgroep: Jongeren tussen 16 - 25 jaar met depressiviteitsklachten.

- Doel: Verminderen van depressiviteitsklachten door het vergroten van inzicht in de klachten en het aanleren van vaardigheden om hier beter mee om te gaan.

- Methode: De cursus bestaat uit tien bijeenkomsten van elk twee uur en een terugkombijeenkomst. Tijdens de bijeenkomsten wordt gerichte informatie, instructies en huiswerkopdrachten gegeven. Het huiswerk wordt besproken en ervaringen daarmee worden gedeeld. Aan de orde komt onder andere 'mood management', ruimte geven aan plezierige activiteiten, het doorbreken van negatieve denkpatronen, verbeteren van sociale vaardigheden. 
- Ontwikkelingsfase: G.

- Aanbod en bereik: De cursus wordt door ongeveer vijftien GGZ-preventieafdelingen uitgevoerd ( $\pm 30 \%$ van alle 54 GGZ-instellingen) en daarnaast door een onbekend aantal onderwijsinstellingen (ROC, HBO en Universiteiten).

- Wetenschappelijke status: ${ }^{* *}$. Deze groepscursus is in de Verenigde Staten effectief bevonden (Clarke et al., 1995, 2001), maar de ingekorte Nederlandse versie is nog niet (voldoende) onderzocht op effectiviteit.

Internetcursus ‘Grip op je dip online’ (www.gripopjedip.nl; Van der Zanden et al., 2005)

Deze cursus is een variant van de eerder beschreven groepscursus 'Grip op je dip’.

- Doelgroep: Jongeren tussen 16-25 jaar met depressiviteitsklachten.

- Doel: Verminderen van depressiviteitsklachten door het vergroten van inzicht in de klachten en het aanleren van vaardigheden om hier beter mee om te gaan.

- Methode: Deze variant wordt via het internet aangeboden. Jongeren kunnen zich via www. gripopjedip.nl aanmelden en na een screening, die eveneens via internet plaatsvindt, deelnemen aan de online groepscursus. De cursus bestaat uit acht bijeenkomsten van anderhalf uur. De cursus vindt plaats in een gesloten chatbox en wordt begeleid door één of twee GGZ-professionals. Er wordt gerichte informatie geven, er wordt met opdrachten gewerkt die weer besproken worden, en ervaringen worden uitgewisseld. Onderwerpen zijn: het doorbreken van negatieve denkpatronen, registratie van stemmingsveranderingen, meer aandacht voor plezierige activiteiten, en versterken van sociale vaardigheden.

- Ontwikkelingsfase: G.

- Aanbod en bereik: De cursus wordt uitgevoerd door vijf GGZ-preventieafdelingen (10\% van alle 54 GGZ-instellingen). In 2006 zullen hier nog eens vijf tot tien instellingen bijkomen. De anonimiteit maakt de cursus voor veel jongeren laagdrempelig.

- Wetenschappelijkestatus: ${ }^{* *}$. Quasi-experimenteel onderzoek toonde aan dat de cursus effectief is in afname van depressiviteitsklachten (Van der Zanden et al., 2005).

\section{Groepscursus 'Stemmingmakerij' (Ruiter, 1997)}

- Doelgroep: Jongeren tussen de 15-19 jaar met lichte depressiviteitsklachten.

- Doel: Deelnemers leren om meer grip te krijgen op hun klachten, waardoor ze meer plezier krijgen in het leven, en thuis en op school beter functioneren.

- Methode: Het programma bestaat uit een informatiebijeenkomst, acht bijeenkomsten van anderhalf uur en een terugkombijeenkomst. Tijdens de bijeenkomsten wordt aandacht geschonken aan het oplossen van problemen, positief denken en sociale steun. Het programma voorziet ook in een informatiebijeenkomst voor ouders.

- Ontwikkelingsfase: G.

- Aanbod en bereik: De Riagg Maastricht startte met de uitvoering van de cursus in het onderwijs. Door de cursus in schooltijd te geven wordt een relatief hoge drempel verlaagd. GGZ Den Bosch en Riagg Midden-Limburg hebben deze werkwijze overgenomen. Daarnaast wordt de cursus door enkele andere GGZ-preventieafdelingen aangeboden. De screening van alle leerlingen van de derde klassen met de zogenaamde Baalmeter (afgeleid van de Beck's Depression Inventory, BDI) staat centraal. In Maastricht scoorde 20\% van de leerlingen hoog op de Baalmeter. Van de leerlingen met een hoge score was vervolgens $20 \%$ bereid tot deelname aan de cursus.

- Wetenschappelijke status: **. In Nederland werd de effectiviteit van de cursus in een quasiexperimentele studie onderzocht op effectiviteit. Deelname aan de cursus leidt tot een duidelijke afname van depressiviteits- en andere psychische klachten. Verder ontstaat verbetering in schoolprestaties, sociale vaardigheden en zelfwaardering (Elling, 2004; Ruiter, 1997). 


\section{Preventieve interventies voor volwassenen}

Tabel 3.5 in paragraaf 3.4.1 biedt een overzicht van de in Nederland beschikbare interventies ter preventie van depressie bij volwassenen.

\section{Universele preventie van depressie bij volwassenen}

Er zijn in Nederland geen interventies beschikbaar voor universele preventie van volwassenen.

\section{Selectieve preventie preventie van depressie bij volwassenen}

Groepscursus 'Leven met een chronische ziekte' (Cuijpers \& Van Osch, 2004; Voordouw et al., 2005)

- Doelgroep: Mensen met een chronische ziekte die depressiviteitsklachten hebben.

- Doel: Verminderen van de depressiviteitsklachten door het vergroten van inzicht in de eigen klachten en het aanleren van vaardigheden die helpen bij het omgaan met de stress die een chronische ziekte met zich meebrengt.

- Methode: De cursus wordt in groepsverband gegeven, maar kan eventueel ook in de vorm van zelfhulp worden gevolgd. De cursus bestaat uit tien bijeenkomsten van elk twee uur met één of meer terugkombijeenkomsten. De bijeenkomsten zijn gestructureerd rondom thema's als stemming, ontspannen, mogelijkheden verkennen en benutten, denkpatronen doorbreken, hulp vragen en krijgen.

- Ontwikkelingsfase: G.

- Aanbod en bereik: Deze cursus wordt door zes tot acht GGZ-preventieafdelingen uitgevoerd, vaak in samenwerking met thuiszorg of met het ziekenhuis.

- Wetenschappelijke status: **. Buitenlands onderzoek laat zien dat deze interventie effect heeft op het ontstaan van depressie (Kühner, 2003). In Nederland werd een quasi-experimenteel onderzoek uitgevoerd waarin een kleine maar statistisch significante afname in depressiviteitsklachten werd aangetroffen (Voordouw et al., 2005).

Groepscursus 'Verlies en dan verder' (Benthem et al., 1994)

Deze interventie wordt beschreven onder selectieve preventie van depressie bij ouderen.

\section{Geïndiceerde preventie van depressie bij volwassenen}

Groepscursus 'In de put, uit de put voor volwassenen' (Cuijpers, 2004a)

- Doelgroep: Volwassen met (beginnende) klachten van depressieve aard.

- Doel: Verminderen van het risico dat een depressieve stoornis ontstaat en verminderen van aanwezige depressiviteitsklachten.

- Methode: De interventie wordt aangeboden als een cursus in groepen van acht tot twaalf personen onder professionele begeleiding. De cursus is gebaseerd op cognitieve-gedragstherapie. In twaalf sessies komen op een gestructureerde wijze thema's aan bod als stemming, ontspannen, denkpatronen doorbreken.

- Ontwikkelingsfase: G.

- Aanbod en bereik: De cursus wordt door circa 85\% van de GGZ-instellingen aangeboden. Momenteel loopt er een implementatietraject waarbij bezien wordt in welke settings (huisarts- en bedrijfsgeneeskunde) de interventie tevens ingezet kan worden. 
- Wetenschappelijke status: ${ }^{* * *}$. Gerandomiseerd effectonderzoek laat zien dat met deze interventie depressiviteitsklachten worden verminderd, maar er konden geen effecten op de incidentie van depressie worden aangetoond (Allart-Van Dam, 2003). Een meta-analyse van gerandomiseerde studies naar deze interventie (Cuijpers et al., aangeboden ter publicatie) weerspiegelt dit beeld. De cursus is dus wel effectief in het verminderen van klachten, maar niet in het reduceren van de incidentie van een depressieve stoornis.

\section{Zelfhulpcursus met minimale begeleiding 'In de put, uit de put' (Willemse et al., 2004)}

- Doelgroep: Volwassen huisartspatiënten met klachten van depressieve aard.

- Doel: Verminderen van het risico dat een depressieve stoornis ontstaat en verminderen van aanwezige depressiviteitsklachten.

- Methode: De interventie wordt aangeboden als een schriftelijke zelfhulpcursus (bibliotherapie) met enige telefonische begeleiding door een preventiewerker. De cursus is gestructureerd rondom thema's als stemming, ontspannen, mogelijkheden verkennen en benutten, denkpatronen doorbreken, hulp vragen en krijgen.

- Ontwikkelingsfase: G.

- Aanbod en bereik: Momenteel loopt er een implementatietraject waarbij bezien wordt in welke settings (huisarts- en bedrijfsgeneeskunde) de interventie ingezet kan worden. Daarnaast start binnenkort een implementatietraject, bedoeld om het bereik van de einddoelgroep, met name in de eerstelijns zorg, te vergroten en om vroegsignalering van geschikte kandidaten voor de zelfhulpcursus te bevorderen.

- Wetenschappelijke status: **. Deze cursus werd onlangs in een gerandomiseerde studie onderzocht en effectief bevonden. De incidentie van depressieve stoornis werd met 30\% teruggebracht (Willemse et al., 2004). Een kosteneffectiviteitsstudie laat bovendien zien dat de interventie kosteneffectief is: er wordt gezondheidswinst gegenereerd en de interventiekosten verdienen zichzelf terug (Smit et al., 2006b; tekstblok 3.1).

\section{Groepsinterventie 'Liever bewegen dan moe’ (Parnassia, 2005)}

- Doelgroep: Laagopgeleide vrouwen met licht depressiviteitsklachten (20-55 jaar).

- Doel: Door lichaamsbeweging ook geestelijk weer in beweging komen en stimuleren om te blijven bewegen, ook na afloop van het programma.

- Methode: De interventie bestaat uit acht bijeenkomsten, inclusief een voorlichtingsbijeenkomst. Iedere bijeenkomst start met het geven van voorlichting over onderwerpen zoals 'bewegen helpt', spanning, voeding, slapen en 'blijven bewegen (na afloop van het programma)'. Vervolgens wordt sportief gewandeld, waarbij naast wandelen in verschillende tempo's aandacht wordt besteed aan ademhaling, houding, coördinatie en concentratie.

- Ontwikkelingsfase: G.

- Aanbod en bereik: De interventie is ontwikkeld door de preventieafdeling van Parnassia en wordt momenteel in Rotterdam en vijf andere plaatsen uitgevoerd. Per locatie gaat het om vijftig tot honderd deelnemers per jaar.

- Wetenschappelijke status: **. Buitenlandse effectstudies hebben aangetoond dat de effectiviteit van bewegingsinterventies even effectief zijn als cognitieve interventies (Lawlor \& Hopker, 2001). In Nederland zijn de effecten nog niet voldoende onderzocht.

\section{Begeleide internetcursus 'Alles onder controle’ (Cuijpers, 2004c)}

- Doelgroep: volwassenen die last hebben van depressiviteitsklachten, angsten, spanningen en werkstress.

- Doel: Een betere greep op het eigen leven krijgen door problemen die verantwoordelijk zijn voor de klachten planmatig aan te pakken.

- Methode: De interventie wordt via het internet aangeboden en op afstand, met e-mails, begeleid door psychologen. 
- Ontwikkelingsfase: I.

- Aanbod en bereik: De cursus wordt momenteel alleen aangeboden in het kader van wetenschappelijk onderzoek.

- Wetenschappelijke status: **. Gerandomiseerd onderzoek (Van Straten et al., in voorbereiding) laat zien dat de interventie gunstige effecten heeft op depressiviteitsklachten, angstklachten, werkstress en burnout.

Groepscursus ‘Bewegen zonder zorgen’ (Gelissen et al., 2006)

- Doelgroep: Vrouwen uit sociaal-economische achterstandsgroepen met stressgerelateerde en depressiviteitsklachten. Deze groep heeft een relatief hoog klachtenniveau en is ondervertegenwoordigd in de reguliere GGZ.

- Doel: Verergering van klachten voorkomen bij vrouwen die niet of laat behandeling in de GGZ ontvangen.

- Methode: De cursus bestaat uit acht bijeenkomsten van anderhalf uur. Centraal staat het draaglast / draagkracht model. Door de combinatie van psycho-educatie en bewegingsoefeningen wordt gewerkt aan het meer in balans brengen van last en draagkracht.

- Ontwikkelingsfase: I.

- Aanbod en bereik: De interventie wordt momenteel in het kader van gerandomiseerd effectonderzoek in Maastricht uitgevoerd in zes tot tien groepen van elk ongeveer twaalf deelnemers. Een vergelijkbare interventie wordt uitgevoerd door GGNet. Dit wordt op twee locaties in Oost-Gelderland uitgevoerd. Per locatie nemen twintig personen deel; beide groepen zitten continu vol.

- Wetenschappelijke status: ${ }^{* *}$. Een pilotstudie laat een afname van depressiviteitsklachten zien na afloop van de cursus (Gelissen, persoonlijke communicatie). Momenteel loopt een gerandomiseerde effectstudie, waarvan de resultaten begin 2008 worden verwacht.

Groepscursus 'Lichte dagen, donkere dagen' (Can \& Voordouw, 2003)

Deze cursus is gebaseerd op de cursus 'In de put, uit de put' (zie boven).

- Doelgroep: Turkse en Marokkaanse mannen en vrouwen met depressiviteitsklachten.

- Doel: Verminderen van depressiviteitsklachten door het vergroten van inzicht in de klachten en het leren van vaardigheden om hier beter mee om te gaan.

- Methode: De cursus wordt in groepen voor vrouwen of mannen gegeven en bestaat uit dertien bijeenkomsten van ongeveer twee uur en een terugkombijeenkomst. Tijdens de bijeenkomsten wordt in de eigen taal informatie gegeven, worden oefeningen en opdrachten uitgevoerd en ervaringen gedeeld. De deelnemers krijgen gerichte opdrachten om thuis uit te voeren.

- Ontwikkelingsfase: G.

- Aanbod en bereik: De cursus wordt in een twintigtal regio's aangeboden (40\% van alle GGZinstellingen), waarbij GGZ-preventie samenwerkt met onder andere allochtone zorgconsulenten en algemeen maatschappelijk werk. Met de cursus worden vooral mensen bereikt uit sociaal-economische achterstandsgroepen die de Nederlandse taal niet of onvoldoende beheersen.

- Wetenschappelijke status: *. Een pilotstudie bij vijftig deelnemers liet een statistisch significante afname van depressiviteitsklachten zien (Can \& Voordouw, 2003). 
- Doelgroep: volwassenen met depressiviteitsklachten. De cursus kent twee varianten: één voor volwassenen en één voor ouderen.

- Doel: Het verminderen van depressieviteitsklachten en daarmee het voorkomen van een depressieve stoornis.

- Methode: Het is een zelfhulpcursus via het internet gebaseerd op cognitief-gedragstherapeutische elementen waarvan de werking bij depressie is aangetoond. Deelnemers gaan geheel zelfstandig met deze cursus aan de slag. De cursus bestaat uit 8 lessen en 1 opfrisles na twaalf weken. De cursus bevat audio, video en flash en de mogelijkheid tot interactie via een forum.

- Ontwikkelingsfase: I.

- Aanbod en bereik: De cursus wordt momenteel alleen aangeboden in het kader van gerandomiseerd effectonderzoek.

- Wetenschappelijke status: *. Er vindt momenteel gerandomiseerd effectonderzoek plaats rond deze volwassencursus. Er zijn nog geen resultaten beschikbaar.

\section{Preventieve interventies voor ouderen}

Tabel 3.13 in paragraaf 3.5.1 biedt een overzicht van de in Nederland beschikbare interventies ter preventie van depressie bij ouderen.

\section{Universele preventie van depressie bij ouderen}

Voorlichtingsfilm 'De kunst van het ouder worden: stil staan en doorgaan bij ingrijpende gebeurtenissen' (Smits, 2003)

Deze film wordt gebruikt in het kader van algemene voorlichtingsactiviteiten.

- Doelgroep: Ouderen die voorlichtingsavonden bezoeken van GGZ-preventieafdelingen.

- Doel: Ouderen bewust maken van hun eigen mogelijkheden om met moeilijke situaties om te gaan, zoals het verlies van een partner.

- Methode: De film (duur: 25 minuten) laat fragmenten zien uit het leven van enkele ouderen en toont hoe zij omgaan met moeilijkheden. Het accent ligt op positieve copingstijlen. De film vormt een uitgangspunt voor een gesprek met ouderen over hun eigen ervaringen en mogelijkheden.

- Ontwikkelingsfase: I.

- Aanbod en bereik: De cursus wordt door GGZ-preventieafdelingen gebruikt voor publieksvoorlichting. Het is onbekend hoe vaak dit gebeurt.

- Wetenschappelijke status: *.

Huiskamerbijeenkomsten ‘Geestelijke gezondheid en ouder worden’ (De Vries \& Smits, 2004)

- Doelgroep: Turkse en Marokkaanse vrouwen van 50 jaar en ouder.

- Doel: Kennis vergroten over ouder worden, geestelijke gezondheid en beschikbaar zorgaanbod.

- Methode: huiskamerbijeenkomsten waarbij één Turkse of Marokkaanse deelnemer optreedt als gastvrouw. Zij nodigt uit haar persoonlijk netwerk anderen uit. Een preventiewerker introduceert de onderwerpen en begeleidt de gesprekken volgens een handboek en draaiboek. Frequentie en duur: de bijeenkomsten duren 2 uren. Het gastvrouwschap wordt doorgegeven, zodat steeds nieuwe groepen ontstaan.

- Ontwikkelingsfase: I. 
- Aanbod en bereik: Het is onbekend door hoeveel GGZ-instellingen deze huiskamerbijeenkomsten aangeboden worden.

- Wetenschappelijke status: *.

\section{Groepscursus ‘Op weg naar de gouden jaren' (Bode \& De Ridder, 2004)}

- Doelgroep: Ouderen tussen de 50 en 70 jaar die zich willen voorbereiden op het ouder worden.

- Doel: Cursisten worden aangemoedigd om over hun toekomst na te denken en realistische plannen te maken. Daarbij is aandacht voor het aanleren van proactieve vaardigheden waarmee problemen in een vroeg stadium voorkomen kunnen worden.

- Methode: De cursus bestaat uit vier bijeenkomsten rondom de volgende thema's: voorbereiden op de volgende levensfase, vroege signalering, positieve doelen, realistische strategieën, en evaluatie. Persoonlijke ambities worden geformuleerd en op basis daarvan worden plannen opgesteld. Tijdens de bijeenkomsten worden discussies gecombineerd met oefeningen.

- Ontwikkelingsfase: I.

- Aanbod en bereik: Het is onbekend door hoeveel instellingen deze groepscursus gebruikt wordt.

- Wetenschappelijke status: ${ }^{*}$. De effectiviteit wordt momenteel onderzocht in een gerandomiseerd onderzoek. De eerste resultaten laten op de korte termijn (na vier weken) significante effecten zien op het niveau van competenties (Bode et al., 2006). Effecten op depressie zijn in deze studie niet gemeten.

\section{Selectieve preventie van depressie bij ouderen}

Groepscursus 'Verlies en dan verder' (Benthem et al., 1994)

- Doelgroep: Oudere weduwen (60+) die sinds een jaar weduwe zijn.

- Doel: Voorkomen van eenzaamheid, bevorderen van sociale contacten, zicht krijgen belemmerende normen, waarde en gedragingen, bevorderen van persoonlijke groei.

- Methode: De cursus bestaat uit elf bijeenkomsten van twee uur en een follow-up bijeenkomst na twee maanden. Per bijeenkomst komen verschillende thema's aan de orde, gerelateerd aan verliesverwerking en het voortzetten van het eigen leven.

- Ontwikkelingsfase: G.

- Aanbod en bereik: Meer dan acht GGZ-instellingen bieden de cursus aan (>13\% van alle GGZinstellingen).

- Wetenschappelijke status: ${ }^{* *}$. Quasi-experimenteel onderzoek laat zien dat de cursisten na afloop van de interventie sociaal vaardiger zijn en minder psychosociale problemen hebben (Benthem et al., 1994; Van Lammeren \& Geelen, 1995).

\section{'Preventie van depressie in verzorgingshuizen' (Van Mierlo et al., 2001)}

- Doelgroep: De interventie richt zich primair op het verzorgend personeel en via hen de bewoners van verzorgingshuizen, maar bevat ook componenten die rechtstreeks gericht zijn op de bewoners. Daarom is deze interventie toch opgenomen in dit overzicht.

- Doel: Deskundigheidsbevordering van verzorgend personeel gericht op vroegherkenning, verbeterde zorg en afname van depressiviteitsklachten. 
- Methode: De interventie bestaat uit drie bijeenkomsten van tweeënhalf uur met de leiding, vier bijeenkomsten met verzorgend personeel, en zes bijeenkomsten voor nieuwe bewoners en hun familie. Na voorbereidende gesprekken met leidinggevenden wordt een cursus aan verzorgenden aangeboden gericht op vroege herkenning van depressie, houding ten opzichte van depressieve bewoners, het wanneer en hoe van meer gespecialiseerde hulpverlening.

- Ontwikkelingsfase: G.

- Aanbod en bereik: De deskundigheidsbevordering wordt momenteel door circa 70 verzorgingshuizen uitgevoerd.

- Wetenschappelijkestatus: **. Quasi-experimenteel onderzoek(Cuijpers \& Van Lammeren, 2001) en een gerandomiseerd onderzoek lieten een afname van depressiviteitsklachten zien.

Groepscursus 'Leven met een chronische ziekte' (Cuijpers \& Van Osch, 2004; Voordouw et al., 2005)

Deze interventie is al beschreven bij selectieve preventie van depressie bij volwassenen.

\section{'Bezoekdiensten van weduwen voor weduwen' (Schaper et al., 1997)}

- Doelgroep: Oudere weduwen en weduwnaars die ongeveer zes maanden geleden hun partner hebben verloren.

- Doel: Bieden van sociale steun, verminderen van depressiviteitsklachten, voorkomen van depressie.

- Methode: De interventie bestaat uit tien huisbezoeken in een tijdsperiode van een jaar. Op basis van de gemeentelijke overlijdensregistratie krijgen weduwen na zes maanden een folder thuis gestuurd over de bezoekdiensten. Als de weduwe interesse heeft wordt ze thuis bezocht door een getrainde vrijwilliger die zelf ook weduwe is. Deze lotgenoot is getraind in het bijstaan van mensen in hun rouwproces.

- Ontwikkelingsfase: G.

- Aanbod en bereik: Circa 15\% van de weduwen en weduwnaars die met informatie over de interventie benaderd worden, maakt gebruik van het aanbod.

Wetenschappelijke status: ${ }^{* *}$. Amerikaans onderzoek laat positieve effecten zien op psychisch disfunctioneren (Vachon et al., 1980). Momenteel wordt Nederlands gerandomiseerd onderzoek uitgevoerd naar de kosteneffectiviteit van de interventie. De eerste resultaten wijzen op significante verschillen op depressie en kwaliteit van leven in het voordeel van de interventiegroep (Onrust et al., in voorbereiding).

Project 'Activerend huisbezoek' (Linnemann et al., 2001)

- Doelgroep: Ouderen (55+) die het door opstapelende problemen (met gezondheid, verlies van dierbaren, kleiner wordend sociaal netwerk, problemen met financiën en huisvesting) niet goed meer redden.

- Doel: Bieden van praktische hulp en sociaal-emotionele steun, activering tot sociale of maatschappelijke participatie.

- Methode: De interventie bestaat uit meerdere werkbezoeken binnen een tijdsbestek van maximaal een jaar. Tijdens de huisbezoeken wordt aandacht besteed aan situatieverheldering, perspectiefontwikkeling, en actieondersteuning. Bij dit laatste worden de doelen omgezet in concrete acties, waarbij de vrijwilliger vooral begeleider is. Als de oudere weer verder kan, wordt de relatie afgebouwd.

- Ontwikkelingsfase: G.

- Aanbod en bereik: Het is onbekend door hoeveel GGZ-instellingen de huisbezoeken worden aangeboden.

- Wetenschappelijke status: *. 


\section{Geïndiceerde preventie van depressie bij ouderen}

Groepscursus 'In de put, uit de put 55+' (Cuijpers, 2004)

De Nederlandse versie werd afgeleid van een cursus die door Lewinsohn (1984) in de Verenigde Staten werd ontwikkeld.

- Doelgroep: Ouderen (55+ jaar) met depressiviteitsklachten.

- Doel: Verminderen van depressiviteitsklachten door het vergroten van inzicht in de klachten en het leren van vaardigheden om hier beter mee om te gaan.

- Methode: De cursus is gebaseerd op de sociale leertheorie over depressie en cognitieve gedragstherapie. In de cursus wordt aandacht besteed aan ontspanning, vermeerderen van het aantal plezierige activiteiten, constructief denken, verbeteren van sociale vaardigheden, en zorgdragen voor het behoud van behaalde effecten.

- Ontwikkelingsfase: G.

- Aanbod en bereik: De cursus wordt door $80 \%$ van de GGZ-instellingen aangeboden.

- Wetenschappelijke status: **. Gerandomiseerd onderzoek toonde aan dat deze interventie effectief is in het reduceren van de risicostatus (Haringsma et al., 2005).

Zelfhulpcursus met minimale begeleiding 'In de put, uit de put' (Cuijpers, 2004)

Deze interventie is al beschreven bij geïndiceerde preventie van depressie bij volwassenen.

Groepscursus 'De verhalen die we leven' (Bohlmeijer, 2006).

- Doelgroep: Ouderen vanaf 55 jaar met depressiviteitsklachten.

- Doel: Versterken van het gevoel van eigenwaarde en zingeving, en vermindering van depressiviteitsklachten.

- Methode: Het betreft een preventieve gespreksgroep voor vier personen waarin vragen over het eigen leven centraal staan. Kern van de methode is dat het 'probleem' dat de deelnemers op dit moment in hun leven ervaren, wordt geplaatst in het perspectief van hun levensloop. Dit kan ertoe leiden dat mensen nieuwe oplossingen bedenken en dat bepaalde gebeurtenissen verwerkt en losgelaten kunnen worden.

- Ontwikkelingsfase: I.

- Aanbod en bereik: De cursus wordt momenteel door negen GGZ-instellingen aangeboden.

- Wetenschappelijke status: **. In het buitenland zijn tal van studies uitgevoerd naar de effecten van soortgelijke interventies - de zogenaamde 'life-review' - op depressiviteitsklachten. Bohlmeijer et al. (2003a) evalueerden in een meta-analyse de effectiviteit van life-review op depressiviteitsklachten, maar we houden een slag om de arm wat betreft de Nederlandse interventie.

\section{Internetcursus 'Kleur je leven', ouderenvariant (Riper \& Kramer, 2004)}

- Doelgroep: Mensen van 50 jaar en ouder met depressiviteitsklachten. De cursus kent twee varianten: één voor volwassenen en één voor ouderen.

- Doel: Het verminderen van depressieviteitsklachten en daarmee het voorkomen van een depressieve stoornis.

- Methode: Het is een zelfhulpcursus via het internet gebaseerd op cognitief-gedragstherapeutische principes waarvan de werking bij depressie is aangetoond. Deelnemers gaan geheel zelfstandig met deze cursus aan de slag. De cursus bestaat uit acht lessen en een opfrisles na twaalf weken. De cursus bevat audio, video en flash en de mogelijkheid tot interactie via een forum.

- Ontwikkelingsfase: I. 
- Aanbod en bereik: De cursus wordt momenteel alleen aangeboden in het kader van gerandomiseerd effectonderzoek en binnenkort in het kader van implementatieonderzoek binnen de GGZ-instellingen.

- Wetenschappelijke status: ${ }^{* *}$. Naar beide varianten loopt momenteel gerandomiseerd effectonderzoek (Spek et al., in voorbereiding). De ouderenvariant heeft een significant effect op het reduceren van een verhoogde risicostatus voor depressie.

Groepscursus ‘Op zoek naar zin’ (Franssen \& Bohlmeijer, 2003)

- Doelgroep: Mensen vanaf 55 jaar met depressiviteitsklachten die bovendien bezig zijn met vragen over zingeving.

- Doel: Zin in het leven terugkrijgen en depressiviteitsklachten tegengaan.

- Methode: De cursus bestaat uit twaalf bijeenkomsten van twee à tweeënhalf uur. Aan de hand van thema's (eerste herinnering, huizen waar je vroeger woonde, belangrijke vriendschappen) halen cursisten herinneringen op en bewerken die herinneringen tot autobiografische teksten. Ook andere creatieve werkvormen zoals schilderen en tekenen kunnen gebruikt worden. Het zelfportret dat zo ontstaat is identiteitsversterkend, helpt bij vragen rondom zingeving, en helpt met het vinden van perspectief.

- Ontwikkelingsfase: G.

- Aanbod en bereik: Van de 54 GGZ- preventieafdelingen bieden er momenteel 32 (60\%) de cursus aan. Dat doen zij meestal twee keer per jaar, in groepen van gemiddeld acht personen. Op jaarbasis zijn dit ruim vijfhonderd personen. Daarnaast wordt de cursus in een onbekend aantal verzorgings- en verpleeghuizen aangeboden.

- Wetenschappelijke status: *. Een niet-gerandomiseerde studie (Bohlmeijer et al., 2003b; Franssen \& Bohlmeijer, 2003) liet zien dat deelnemers meer greep hebben op hun leven, minder depressiviteitsklachten hebben en meer tevreden zijn met hun leven. Momenteel wordt een gerandomiseerd effectonderzoek in Nederland uitgevoerd, waarvan de resultaten in 2007 worden verwacht (voor meer informatie zie www.opzoeknaarzin.nl). 


\section{BIJLAGE 4 INTERVENTIES GERICHT OP DE PREVENTIE VAN ANGSTSTOORNISSEN}

In hoofdstuk 4 worden de in Nederland beschikbare preventieve interventies kort beschreven. De nadruk ligt daar op het onderzoek naar de effectiviteit van de interventies. In deze bijlage geven we een uitgebreider beschrijving van de interventies, met meer aandacht voor de inhoud van de interventie, het aanbod en het bereik. Voor iedere interventie gaan we achtereenvolgens in op de doelgroep, het doel, de methode, aanbod en bereik, de ontwikkelingsfase en de wetenschappelijke status.

In dit overzicht wordt de indeling in het hoofdstuk gevolgd. De interventies worden per leeftijdsgroep beschreven: eerst voor jongeren en vervolgens voor volwassenen en ouderen. Per leeftijdsgroep komen achtereenvolgens de universele, selectieve en geïndiceerde preventieve interventies aan bod. De indeling naar ontwikkelingsfase (G, I of B) staat beschreven in paragraaf 2.3. De wetenschappelijke status ( ${ }^{*},{ }^{* *}$ of $\left.{ }^{* * *}\right)$ en de gehanteerde uitkomstmaat (I, R of K) worden beschreven in paragraaf 2.4.

\section{Preventieve interventies voor jongeren}

Tabel 4.3 in paragraaf 4.3.1 biedt een overzicht van de in Nederland beschikbare interventies ter preventie van angststoornissen bij jongeren.

\section{Universele preventie van angststoornissen bij jongeren}

\section{Voorlichtingsbijeenkomsten}

- Doelgroep: Jongeren, ouders en andere betrokkenen zoals leerkrachten en huisartsen die meer willen weten over psychiatrische ziektebeelden bij jongeren.

- Doel: Voorlichting geven over het verschil tussen klachten gebonden aan levensfasen en psychopathologie, en informatie geven over het corresponderende zorgaanbod.

- Methode: Groepsvoorlichtingsbijeenkomsten.

- Ontwikkelingsfase: I.

- Aanbod en bereik: Deze voorlichting wordt door enkele GGZ-instellingen aangeboden.

- Wetenschappelijke status: Onbekend.

\section{Voorlichtingsbijeenkomst voor (alleenstaande) minderjarige asielzoekers}

- Doelgroep: Asielzoekers en alleenstaande minderjarige asielzoekers uit verschillende taalgroepen.

- Doel: Asielzoekers krijgen handvatten aangereikt over het omgaan met psychische problemen waaronder angst.

- Methode: Groepsvoorlichtingsbijeenkomst. Dit is een onderdeel van het meer omvattende project 'How to keep your life in balance?' voor asielzoekers.

- Ontwikkelingsfase: I.

- Aanbod en bereik: Deze voorlichting wordt door enkele GGZ-instellingen aangeboden.

- Wetenschappelijke status: Onbekend. 
De cursus 'Vrienden' is een Nederlandse bewerking van het programma Friends uit Australië. De cursus is geschikt voor universele, selectieve en geïndiceerde preventie; hij staat beschreven bij geïndiceerde preventie van angststoornissen bij jongeren.

\section{Selectieve preventie van angststoornissen bij jongeren}

Lesprogramma 'Plezier op school' (Geerlings \& Lissenburg, 2005)

- Doelgroep: Beginnende brugklassers (12-14 jaar) die problemen hebben met sociale contacten. Dit zijn kinderen die het slachtoffer zijn van pesterijen, angstig, vermijdend of onhandig zijn in contact met leeftijdsgenoten.

- Doel: Het vergroten van de competentie van jongeren om ernstige psychische problemen te verminderen of te voorkomen; sociale basisvaardigheden aanleren. Hierdoor kunnen ze succesvoller hun nieuwe leergang voltooien.

- Methode: Dit programma is gebaseerd op cognitieve gedragstherapeutische technieken, gecombineerd met ontspanningstechnieken. Het programma bestaat uit een tweedaagse training in de week voordat de jongere naar de brugklas gaat. Frequentie en duur: de tweedaagse training wordt in de laatste week van de zomervakantie gehouden, vlak voordat de jongere naar de nieuwe school gaat.

- Ontwikkelingsfase: I.

- Aanbod en bereik: Deze cursus wordt door enkele GGZ-instellingen aangeboden.

- Wetenschappelijke status: *. Er zijn aanwijzingen dat het programma effecten heeft op sociale angst en op gepest worden (Geerlings \& Lissenburg, 2005).

Vrienden (groepscursus of individuele cursus) (NIZW, 2005)

De cursus 'Vrienden' is een Nederlandse bewerking van het programma Friends uit Australië. De cursus is geschikt voor universele, selectieve en geïndiceerde preventie. Deze cursus staat beschreven bij geïndiceerde preventie van angststoornissen bij jongeren.

\section{Geïndiceerde preventie van angststoornissen bij jongeren}

Vrienden (groepscursus of individuele cursus) (NIZW, 2005)

De cursus 'Vrienden' is een Nederlandse bewerking van het programma Friends uit Australië. De cursus is geschikt voor universele, selectieve en geïndiceerde preventie.

- Doelgroep: Jongeren tussen de 12 en 16 jaar met milde symptomen van angst. Er is ook een versie voor jongere kinderen van 7 tot en met 11 jaar.

- Doel: Het voorkomen en behandelen van angst- en depressiestoornissen bij jeugdigen.

- Methode: Het programma kan in groepsverband of individueel worden aangeboden. De groepscursus bestaat uit tien bijeenkomsten en vier ouderbijeenkomsten. Het bestaat uit meerdere componenten en is geschikt voor universele, selectieve en geïndiceerde preventie. Aan de hand van oefeningen leren jongeren verschillende vaardigheden en technieken die hen helpen om te gaan met gevoelens van angst en depressie. De oefeningen hebben betrekking op de drie gebieden die van invloed zijn op het ontwikkelen en in stand blijven van een angst- of depressiestoornis: lichamelijke reacties, gedachten en leer- en gedragsprocessen. Jongeren die klachten hebben op het gebied van angst en depressie leren de betreffende klachten beter onder controle te krijgen.

- Ontwikkelingsfase: G. 
- Aanbod en bereik: De interventie wordt aangeboden door het Sophia Kinderziekenhuis te Rotterdam (ErasmusMC). Het programma wordt door meerdere GGZ-instellingen en op meerdere scholen uitgevoerd.

- Wetenschappelijke status: ${ }^{* *}$. Momenteel loopt er een Nederlands gerandomiseerd onderzoek naar dit programma, waarvan de resultaten verwacht worden in 2006. In een gerandomiseerde studie in Australië onder kinderen (10 tot en met 13 jaar) bleek de interventie de kans op het ontstaan van een angststoornis significant te verminderen. Dit effect bleek ook na een jaar behouden (Lowry-Webster et al., 2003).

Lesprogramma 'Plezier op school' (Geerlings \& Lissenburg, 2005)

Dit programma is geschikt als selectieve en geïndiceerde preventie. Het is beschreven bij selectieve preventie van angststoornissen bij jongeren'.

Website 'Zo gek nog niet' (www.zogeknogniet.nl, Stichting Pandora)

- Doelgroep: Jongeren met psychische problemen.

- Doel: Informatie geven over psychische problemen, onder andere via een rubriek 'vraag en antwoord'. De site richt zich niet alleen op angst, maar ook op algemene psychische klachten.

- Methode: Aanbod via website.

- Ontwikkelingsfase: G.

- Wetenschappelijke status: Onbekend. Buitenlandse studies geven aanwijzingen dat internetgebaseerde therapieën voor angst en depressie effectief zijn in een curatieve setting (Kaltenthaler et al., 2002).

\section{Buitenlandse interventie 'Angstmanagementtraining' (Hains, 1992)}

- Doelgroep: Scholieren in de laatste klas van het middelbaar onderwijs die zich voorbereiden op het hoger onderwijs.

- Doel: Het verminderen van angst en stress, en versterken van het zelfvertrouwen.

- Methode: De training is gebaseerd op de cognitieve gedragstherapie.

- Ontwikkelingsfase: $\mathrm{B}$.

- Aanbod en bereik: De interventie wordt nog niet in Nederland aangeboden.

- Wetenschappelijke status: ${ }^{*}$. De interventie is effectief in het reduceren van angstklachten (Hains, 1992).

\section{Buitenlandse interventie 'Stress-inoculation training' (Kiselica et al., 1994)}

- Doelgroep: Jongeren (16 tot en met 19 jaar) aan einde van de middelbare school met stressen angstklachten.

- Doel: Angst en stressklachten te verminderen, verbeteren van schoolprestaties, en het aanleren van goed gedoceerde assertiviteit.

- Methode: De training is gebaseerd op een combinatie van ontspanningsoefeningen, cognitieve herstructurering en assertiviteitstraining.

- Ontwikkelingsfase: B.

- Aanbod en bereik: De interventie wordt nog niet in Nederland aangeboden.

- Wetenschappelijke status: **. De interventie is in het buitenland effectief in het reduceren van angstklachten, hoewel het gemiddelde klachtenniveau in Nederland boven de klinisch relevante grens bleven (Kiselica et al., 1994). 


\section{Preventieve interventies voor volwassenen en ouderen}

Tabel 4.7 in paragraaf 4.4.1 biedt een overzicht van de in Nederland beschikbare interventies ter preventie van angststoornissen bij volwassenen en ouderen.

\section{Universele preventie van angststoornissen bij volwassenen en ouderen}

Campagne 'Kopzorgen' (Van de Plassche, 2004)

- Doelgroep: Mensen van 18 jaar en ouder met milde angst- en depressiviteitsklachten.

- Doel: Ondermeer bewustmaking en het bespreekbaar maken van angst- en depressiviteitsklachten. Gestreefd wordt om het taboe rond angst- en depressiviteitsklachten te doorbreken.

- Methode: Verschillende activiteiten, waaronder een tentoonstelling, zijn ingezet om de doelgroep te bereiken en om het gelijknamige zelfhulpboek aan te bieden.

- Ontwikkelingsfase: Onbekend.

- Aanbod en bereik: Onbekend.

- Wetenschappelijke status: Onbekend. Het is niet bekend in hoeverre deze campagne geleid heeft tot meer bekendheid onder de doelgroep en tot bewustwording van klachten (Van de Plassche, 2004).

\section{Selectieve preventie van angststoornissen bij volwassenen en ouderen}

In Nederland zijn geen selectieve interventies gericht op de preventie van angststoornissen bij volwassenen en ouderen.

\section{Geïndiceerde preventie van angststoornissen bij volwassenen en ouderen}

Begeleide internetcursus 'Alles onder controle' (Cuijpers, 2004).

- Doelgroep: Volwassenen die last hebben van depressiviteitsklachten (zie ook bijlage 3), angsten, spanningen en/of werkstress.

- Doel: Een betere greep op het eigen leven te krijgen door problemen die verantwoordelijk zijn voor de klachten gericht en planmatig aan te pakken.

- Methode: De cursus wordt via het internet aangeboden, en begeleid door psychologen, per mail.

- Ontwikkelingsfase: I.

- Aanbod en bereik: Alleen aangeboden in het kader van onderzoek.

- Wetenschappelijke status: ${ }^{* *}$. In gerandomiseerd onderzoek leidde de cursus tot een significante afname van angstklachten (Van Straten et al., in voorbereiding).

Zelfhulp-groepscursus 'Hallo, hier ben ik' (Van der Molen, 1985)

In 1985 promoveerde Van der Molen op een effectevaluatie van de cursus 'Aan verlegenheid valt iets te doen'. Later heeft Van Wandelen deze cursus bewerkt tot een zelfhulpboek 'Hallo, hier ben ik'.

- Doelgroep: Verlegen mensen en mensen met beginnende klachten van sociale fobie.

- Doel: Hanteren van verlegenheidsklachten en voorkomen dat deze verergeren. 
- Methode: De gelijknamige cursus wordt aangeboden door de Vereniging voor Verlegen Mensen (www.verlegenmensen.nl). De cursisten zijn leden van de vereniging (circa 900 personen). Een aantal van hen heeft al langer hulp gezocht. Anderen hebben beginnende symptomen van sociale fobie en grijpen de cursus aan om verlichting te brengen in hun klachten. De deelnemers gaan zelf, maar in een groep van lotgenoten (acht tot twaalf personen), aan de slag met verlegenheid. De eerste vier groepssessies worden onder professionele begeleiding (een oud-lid van de Vereniging) aangeboden, daarna gaat de groep op eigen kracht nog een jaar lang verder.De groepsbijeenkomsten worden gebruikt om zelfstandig te werken met het boek 'Hallo, hier ben ik'. Het totaal aantal bijeenkomsten is twintig en deze worden verdeeld over een heel jaar.

- Ontwikkelingsfase: G.

- Aanbod en bereik: De cursus wordt jaarlijks in twaalf tot vijftien regio's aangeboden. Een voorloper daarvan werd eerst vanuit de GGZ aangeboden, maar tegenwoordig wordt het alleen aangeboden door de 'Vereniging voor verlegen mensen'.

- Wetenschappelijke status: *.

Schriftelijke zelfhulpcursus 'Zelf aan de slag met angstige gevoelens' (Van Mierlo et al., 2004)

- Doelgroep: Mensen met lichte tot matige angstklachten, in het bijzonder klachten rondom paniek, sociale fobie en gegeneraliseerde angst.

- Doel: Voorkomen van angststoornis, afname van angstklachten, leren van vaardigheden om de angstklachten te hanteren en voorkomen van terugval.

- Methode: De cursus is gebaseerd op gedragstherapeutische principes. De cursist werkt zelfstandig in gemiddeld zes tot acht weken de schriftelijke cursus door. Voor aanvang vindt er een kennismakingsgesprek plaats met een begeleider. Het doorwerken van de map wordt ondersteund door telefonische begeleiding.

- Ontwikkelingsfase: G.

- Aanbod en bereik: De cursus wordt door meerdere GGZ-instellingen aangeboden.

- Wetenschappelijke status: *. Er zijn nog geen resultaten vanuit gerandomiseerd effectonderzoek beschikbaar. Tevredenheidsgegevens laten in het algemeen een positief beeld zien (Medema, 2003; Dijkens, 2004a en b).

Groepscursus 'Angst in de Hand' (Van Mierlo et al., 2005) en groepscursus 'Angst de Baas' (Timmerman, 2004). Deze cursussen zijn twee varianten van elkaar, daarom bespreken we ze samen.

- Doelgroep: Mensen van 18-55 jaar (apart voor 55+) met milde tot matige klachten rondom paniek, sociale fobie en gegeneraliseerde angst.

- Doel: Voorkomen van een angststoornis, door het leren hanteren van angstklachten en het verhogen van welbevinden.

- Methode: Beide cursussen zijn gebaseerd op cognitieve gedragstherapie en omvatten doorgaans acht bijeenkomsten. Centraal staan het leren ontspannen, herkennen van gedachten die angst beïnvloeden, stapsgewijs oefenen van moeilijke situaties, en het doorbreken van vermijding. Van 'Angst in de hand' bestaat een aparte versie voor studenten, en voor ouderen is er de cursus 'Angst de Baas 55+' (Akkermans et al., 2003).

- Ontwikkelingsfase: G

- Aanbod en bereik: De cursus wordt door meerdere GGZ-instellingen aangeboden.

- Wetenschappelijke status: *. Bij de ouderenvariant van 'Angst de Baas' werd in een nietgerandomiseerde effectstudie een significante afname van angstklachten gevonden (Van Helsdingen, 2004). 
- Doelgroep: Turken en Marokkanen van 50 jaar en ouder met angstklachten of een lichte angststoornis.

- Doel: Voorkomen van een angststoornis, omgang met klachten verbeteren zodat die klachten hen minder beperken in het dagelijks functioneren en de kwaliteit van leven toeneemt.

- Methode: Deze cursus is vergelijkbaar met 'Angst in de hand' en 'Angst de baas'.

- Ontwikkelingsfase: $\mathrm{G}$. Er is een gestandaardiseerd draaiboek beschikbaar.

- Aanbod en bereik: De cursus wordt door meerdere GGZ-instellingen aangeboden.

- Wetenschappelijke status: *.

Groepscursus ‘Geen Paniek!’ (Meulenbeek et al., 2005)

Voor meer informatie zie de website www.cursusgeenpaniek.nl.

- Doelgroep: Mensen van 18-65 jaar met milde tot matige paniekklachten met of zonder agorafobische klachten.

- Doel: Reductie van paniekklachten, voorkomen dat de klachten of de gevolgen hiervan verergeren en dat personen die van een paniekstoornis hersteld zijn een terugval krijgen.

- Methode: De cursus is gebaseerd op cognitieve gedragstherapie en omvat 8 bijeenkomsten waarin de volgende onderdelen centraal staan: psycho-educatie, ontspanningsoefeningen, gewennings- en gedragsoefeningen.

- $\quad$ Ontwikkelingsfase: G. Gestandaardiseerd draaiboek beschikbaar.

- Aanbod en bereik: De cursus wordt door verschillende preventieafdelingen van GGZ-instellingen aangeboden.

- Wetenschappelijke status: *. De cursus met acht bijeenkomsten bleek net zo effectief als een variant met 12 bijeenkomsten. Op basis van deze resultaten is het cursusmateriaal aangepast. Momenteel vindt een RCT annex kosten-effectiveitsstudie plaats. De resultaten daarvan worden verwacht in 2007. Een pilotstudy (Willemse \& Smit, 2004) liet significante afname zien van paniekklachten, vermijding, agorafobische cognities en lichamelijke gewaarwordingen.

Groepscursus 'Leren omgaan met verlegenheid’ (Rademakers \& Groen, 2003)

- Doelgroep: Mensen van 18 jaar en ouder die last hebben van sociaal fobische klachten.

- Doel: Deelnemers handvatten geven om de klachten te hanteren en te voorkomen dat deze verergeren.

- Methode: De cursus is gebaseerd op gedragstherapeutische technieken, sociale vaardigheden en probleemoplossende technieken. Het aantal bijeenkomsten varieert van acht tot twaalf.

- Ontwikkelingsfase: I. Een recente versie van deze cursus is in ontwikkeling: 'Met Lef: Zelfverzekerd in contact met anderen'.

- Aanbod en bereik: Onbekend.

- Wetenschappelijke status: ${ }^{*}$. Op uitkomstmaten worden momenteel door verschillende instellingen gegevens verzameld.

\section{Begeleide zelfhulpcursus 'Geen Paniek' en 'Angst de baas'}

Deze zelfhulpcursussen zijn afgeleid van de gelijknamige groepscursussen die eerder werden beschreven.

- Doelgroep en doel: Zie de betreffende groepscursussen hierboven.

- Methode: Deze cursussen zijn afgeleid van de gelijkgenoemde groepscursussen.

- Ontwikkelingsfase: I.

- Aanbod en bereik: De zelfhulpvariant wordt door enkele GGZ-instellingen aangeboden

- Wetenschappelijke status: onbekend. 
Buitenlandse interventie 'Eéndaagse workshop voor paniekklachten' (Gardenswartz \& Craske, 2001; zie ook WHO, 2004)

- Doelgroep: Mensen die minstens één paniekaanval hebben gehad, zonder dat zij voldeden aan de criteria voor een paniekstoornis

- Doel: voorkomen van een paniekstoornis, vermindering van aan paniek gerelateerde catastrofale cognities en vermijding

- Methode: Het betreft een ééndaagse workshop gebaseerd op cognitief-gedragstherapeutische principes.

- Ontwikkelingsfase: B.

- Aanbod en bereik: De cursus wordt nog niet in Nederland aangeboden.

- Wetenschappelijke status: ${ }^{* *}$. Uit gerandomiseerd onderzoek bleek dat de cursus het ontstaan van paniekstoornis effectief kan voorkomen (Gardenswartz \& Craske, 2001). De cursus is daarnaast kosteneffectief, zoals blijkt uit de economische doorrekening in bijlage 6 .

Buitenlandse interventie 'Psycho-educatieve instructie op eerste hulppost' (Swinson et al., 1992)

- Doelgroep: Mensen die met paniekklachten en agorafobische klachten op een eerste hulppost van een ziekenhuis verschijnen

- Doel: Een vermindering van paniekaanvallen en agorafobische klachten.

- Methode: De cursus wordt aangeboden op een eerste hulppost van een ziekenhuis.

- Ontwikkelingsfase: $\mathrm{B}$.

- Aanbod en bereik: De cursus wordt nog niet in Nederland aangeboden.

- Wetenschappelijke status: **. Gerandomiseerd onderzoek liet een significante reductie zien in aantal paniekaanvallen, maar geen significante afname van agorafobische klachten (Swinson et al., 1992).

Buitenlandse interventie 'Cognitieve internetinterventie’ (Kenardy et al., 2003)

- Doelgroep: Mensen met beginnende paniekklachten.

- Doel: Vermindering van paniekklachten en vermindering van aan paniek gerelateerde catastrofale gedachten.

- Methode: De internetcursus bestaat uit zes gestructureerde sessies die in vijf tot zeven dagen doorlopen kunnen worden.

- Ontwikkelingsfase: B.

- Aanbod en bereik: De cursus wordt nog niet in Nederland aangeboden, maar is al wel in voorbereiding.

- Wetenschappelijke status: ${ }^{* *}$. Gerandomiseerd onderzoek laat significante middelgrote effecten op angstklachten zien. 



\section{BIJLAGE 5 INTERVENTIES GERICHT OP DE PREVENTIE VAN ALCOHOLMISBRUIK EN -AFHANKELIJKHEID}

In hoofdstuk 5 worden de in Nederland beschikbare preventieve interventies kort beschreven. De nadruk ligt daar op het onderzoek naar de effectiviteit van de interventies. In deze bijlage geven we een uitgebreider beschrijving van de interventies, met meer aandacht voor de inhoud van de interventie, het aanbod en het bereik. Voor iedere interventie gaan we achtereenvolgens in op de doelgroep, het doel, de methode, aanbod en bereik, de ontwikkelingsfase en de wetenschappelijke status.

In dit overzicht wordt de indeling in het hoofdstuk gevolgd. De interventies worden per leeftijdsgroep beschreven: eerst voor jongeren en vervolgens voor volwassenen en ouderen. Per leeftijdsgroep komen achtereenvolgens de universele, selectieve en geïndiceerde preventieve interventies aan bod. De indeling naar ontwikkelingsfase (G, I of B) staat beschreven in paragraaf 2.3. De wetenschappelijke status (*, ${ }^{* *}$ of ${ }^{* * *}$ ) en de gehanteerde uitkomstmaat (I, R of $\mathrm{K}$ ) worden beschreven in paragraaf 2.4. De overheidsinterventies die uitgebreid staan beschreven in paragraaf 5.3 worden in deze bijlage niet nader uitgewerkt.

\section{Preventieve interventies voor jongeren}

\section{Universele preventie van alcoholmisbruik en -afhankelijkheid bij jongeren}

Lesprogramma 'De gezonde school en genotmiddelen' (Cuijpers et al., 2002)

Dit is een breed genotmiddelenpreventieprogramma.

- Doelgroep: Jongeren in de leeftijd van 12-16 jaar.

- Doel: Leerlingen wordt geleerd om een voor de eigen gezondheid en de gezondheid van anderen verantwoorde keuze te maken met betrekking tot genotmiddelen.

- Methode: Het programma bestaat uit een serie lessen in het voortgezet onderwijs waar alcoholpreventie een onderdeel van vormt. lessenserie over tabak, alcohol en cannabis. De lessen worden ondersteund door een stuurgroep, ouderactiviteiten, een genotmiddelenbeleid op school en signalering en begeleiding van risicoleerlingen.

- Ontwikkelingsfase: G. Het programma wordt op lokaal niveau geïmplementeerd door GGDen en Instellingen voor verslavingszorg (IVZ). De implementatie wordt ondersteund door het Trimbos-instituut. Een aantal regionale instellingen heeft een eigen variant van deze interventie ontwikkeld en biedt deze in de eigen regio aan.

- Aanbod en bereik: Op ongeveer de helft van alle scholen voor Voortgezet Onderwijs wordt dit genotmiddelenpreventieprogramma uitgevoerd (Lemmers et al., 2003).

- Wetenschappelijke status: **. Een uitgebreide quasi-experimentele effectstudie toonde aan (Cuijpers et al., 2002; Smit et al., 2003) dat het programma een gunstig effect heeft op de kennis, houding en vaardigheden met betrekking tot alcoholgebruik. Ook leidt het programma tot een reductie in alcoholgebruik; dit effect houdt tenminste drie jaar aan. Momenteel loopt er een gerandomiseerd onderzoek naar de interventie. 
- Doelgroep: Ouders van jongeren onder de 16 jaar.

- Doel: Bieden van advies en ondersteuning aan ouders om alcoholgebruik bij kinderen op jonge leeftijd te voorkomen.

- Methode: Het project combineert verschillende grote landelijke programma’s; een deelcampagne van de NIGZ-alcoholcampagne en het programma 'De gezonde school en genotmiddelen' van het Trimbos-instituut. Monitoring loopt via het peilstationsonderzoek, waarbij aanvullende oudergegevens verzameld en gekoppeld worden, een jongeren internetpanel en RVD-tracking onderzoek.

- Ontwikkelingsfase: I. Voor het creëren van draagvlak en implementeren van het nieuwe alcoholadvies in de regio wordt gebruik gemaakt van de bestaande infrastructuur en netwerken zoals de steunpunten AVP, de regiobijeenkomsten Drugs Voorlichting Preventie, het netwerk 'De gezonde school en genotmiddelen', en de contacten en netwerken van het Landelijk steunpunt preventie. Hiermee is een samenhangende aanpak gewaarborgd.

- Aanbod en bereik: Het project is recent gestart.

- Wetenschappelijke status: ${ }^{* *}$. Deze wetenschappelijke status is gebaseerd op de status van de reeds onderzochte onderdelen (zie boven).

\section{Programma 'Preventief GezondheidsOnderzoek'}

Dit programma wordt ter bevordering van de Jeugdgezondheidszorg (JGZ) door GGD-en op scholen aangeboden. Hierbij wordt onder andere aandacht besteed aan preventie van alcoholmisbruik en -afhankelijkheid.

- Doel: Stimuleren gezond gedrag.

- Doelgroep: Leerlingen 1e en 2e klas voortgezet onderwijs.

- Methode: Door middel van dit onderzoek wordt beoogd om vroegtijdige risico's op ongezond of riskant gedrag in te schatten. Leerlingen voeren een 15-20 minuten durend gesprek met een GGD-medewerker die naast meten en wegen van de leerling ook vraagt naar diens fysieke en psychische welbevinden en naar het gebruik van genotmiddelen. Leerlingen krijgen vervolgens een persoonlijk advies. Een variant hierop is een open consultatie-uur, een inloopspreekuur dat leerlingen op eigen verzoek kunnen bezoeken met vragen of problemen ten aanzien van hun gezondheid.

- Ontwikkelingsfase: G.

- Aanbod en bereik: Het programma wordt door verschillende GGD-en uitgevoerd.

- Wetenschappelijke status: niet effectief. Er is bewijs dat deze interventie op bevolkingsniveau niet of nauwelijks leidt tot minder alcoholgebruik (Wiegersma et al, 2003).

\section{Selectieve preventie van alcoholmisbruik en -afhankelijkheid bij jongeren}

\section{Preventieproject 'Drank, de kater komt later' (NIGZ)}

- Doelgroep: Veeldrinkende jongeren die uitgaan of op vakantie zijn.

- Doel: Het voorkomen van overmatig alcoholgebruik door jongeren in hun vrije tijd.

- Methode: Het betreft een combinatie van massamediale activiteiten en peereducatie. De campagne wordt door het NIGZ in samenwerking met instellingen voor verslavingszorg in de zomermaanden op jongerencampings uitgevoerd en het gehele jaar door op evenementen waar veel jongeren zijn. Speciaal opgeleide jongerenvoorlichters informeren via gesprekken, testjes en speciale campagnematerialen over de gevolgen van overmatig alcoholgebruik.

- Ontwikkelingsfase: Er bestaat een handleiding voor de uitvoering van de methodiek. Het NIGZ biedt ondersteuning bij de uitvoering op lokaal niveau.

- Aanbod en bereik: De meeste instellingen voor verslavingszorg maken hiervan gebruik. 
- Wetenschappelijke status: *. Er werden meerdere (quasi-) experimentele effectstudies uitgevoerd (Cuijpers et al., 2005). Daarbij zijn vooral effecten gevonden op kennis gevonden en in mindere mate op houding en intentie. (Spapen \& De Weerdt, 2000; De Graaff, 2002; De Graaff \& Poort, 2003). Jongeren die door leeftijdsgenoten zijn voorgelicht hebben meer kennis over de risico's van alcoholgebruik. Er zijn echter geen effecten gevonden op alcoholgebruik; vandaar de beperkte wetenschappelijke status.

\section{'Homeparty'}

Deze interventie werd in 1998 ontwikkeld in het kader van het project 'Resultaten Scoren' (Riper et al., 2004; Bolier \& Riper, 2004).

- Doelgroep: Gezinnen uit achterstandswijken en gezinnen met een niet-Nederlandse achtergrond.

- Doel: Ouders leren omgaan met het experimenteren en gebruiken van genotmiddelen van hun kinderen.

- Methode: Naar analogie van de 'tupperware parties' worden huiskamerbijeenkomsten georganiseerd door een gastouder. Deze gastouder nodigt uit zijn of haar directe omgeving andere ouders uit die ook meer willen weten over genotmiddelengebruik van hun kinderen. Een preventiemedewerker met dezelfde culturele achtergrond verzorgt de bijeenkomsten. De bijeenkomsten worden indien gewenst in de eigen taal uitgevoerd.

- Ontwikkelingsfase: G. De homeparty wordt door verschillende verslavingszorg instellingen uitgevoerd.

- Wetenschappelijke status: *.

Groepscursus 'KVO-groep: Kinderen van Verslaafde Ouders' (Van den Boer et al., 2002; Vos et al., 2002)

- Doelgroep: Kinderen van verslaafde ouders. Zij vormen een risicogroep voor het ontwikkelen van alcoholproblemen.

- Doel: Doorbreken van het isolement van deze kinderen, het bevorderen van een reële kijk op zichzelf en de ouder en kinderen beter leren omgaan met negatieve reacties en eigen gevoelens.

- Methode: Er zijn draaiboeken voor kinder- en pubergroepen ontwikkeld. Er zijn gemiddeld 8 bijeenkomsten, waar de jongeren volgens een vast protocol hun problemen en ervaringen met elkaar bespreken.

- Ontwikkelingsfase: G.

- Aanbod en bereik: De meeste GGZ- en IVZ-instellingen bieden deze groepsinterventie aan.

- Wetenschappelijke status: * (Beurkens \& Siebes, 1998).

Website ‘Drankjewel’ (www.drankjewel.nl; Riper \& Conijn, 2003)

De website is van het Trimbos-instituut.

- Doelgroep: Kinderen van ouders met alcoholproblemen.

- Doel: Voorkomen van problemen als gevolg van de problematiek van de ouders, door kinderen te informeren en hen helpen om met hun problemen om te gaan.

- Methode: Informatie verstrekken, contact met forum en chatten met professionals.

- Ontwikkelingsfase: G. De website wordt door het Trimbos-instituut onderhouden.

- Aanbod en bereik: Sinds de lancering trekt de website (het deel voor de kinderen) gemiddeld ongeveer vierduizend bezoekers per maand.

- Wetenschappelijke status: ${ }^{*}$ (Riper \& Conijn, 2003). 


\section{Integraal programma 'Uitgaan en drugs'}

Het Trimbos-instituut en de Instellingen voor verslavingszorg hebben dit programma ontwikkeld (Bolier et al., 2005).

- Doelgroep: Jongeren en jong volwassenen die overmatig drinken, al of niet in combinatie met het gebruik van uitgaansdrugs.

- Doel: Tegengaan van riskant alcohol- en drugsgebruik tijdens het uitgaan, en zo de (gezondheids)schade van alcohol en drugsgebruik te beperken.

- Methode: Het programma bestaat uit een monitoringinstrument, een module netwerkontwikkeling in het uitgaanscircuit, een cursus voor horecapersoneel, voorlichting voor uitgaanders en een cursus Eerste Hulp bij Drugsongevallen in het uitgaanscircuit. Deze modules vormen samen een integrale aanpak voor alcohol- en drugspreventie in het uitgaanscircuit.

- Ontwikkelingsfase: G. Het Trimbos-instituut verzorgt trainingen voor instellingen voor verslavingszorg om te leren werken met de verschillende modules.

- Aanbod en bereik: De meeste instellingen voor verslavingszorg maken in hun dagelijkse praktijk inmiddels gebruik van de door dit project ontwikkelde handleidingen en producten om een preventiebeleid in het uitgaanscircuit op te zetten.

- Wetenschappelijke status: *.

Project 'Big deal' (Blitterswijk, 2004)

- Doelgroep: Vriendengroepen in de leeftijdscategorie van 10 - 25 jaar.

- Doel: Voorkomen van riskant gebruik van genotmiddelen door vergroten van kennis en inzicht en bevorderen van sociale competentie.

- Methode: Dit project is gebaseerd op 'peer-educatie', waarbij leeftijdsgenoten kennis en inzichten over het gebruik van genotmiddelen. met elkaar uitwisselen.

- Ontwikkelingsfase: G. Handleiding met protocol is beschikbaar. Via instellingen voor verslavingszorg worden jongerenwerkers getraind in de methodiek.

- Aanbod en bereik: Er zijn geen gegevens over de toepassing in de praktijk beschikbaar.

- Wetenschappelijke status: *.

\section{Geïndiceerde preventie van alcoholmisbruik en -afhankelijkheid bij jongeren}

Er zijn in Nederland geen interventies beschikbaar voor geïndiceerde preventie van alcoholmisbruik en -afhankelijkheid bij jongeren.

\section{Preventieve interventies voor volwassenen en ouderen}

De interventies die we hierna beschrijven zijn gericht op volwassenen van 18 jaar en ouder. In Nederland worden geen interventies aangeboden ter preventie van alcoholmisbruik en -afhankelijkheid die zich specifiek richten op ouderen. Voor de hierna beschreven interventies geldt dat ze in principe ook bruikbaar zijn voor ouderen.

\section{Universele preventie van alcoholmisbruik en -afhankelijkheid bij volwassenen en ouderen}

Universele preventie van alcoholmisbruik en -afhankelijkheid bij volwassenen en ouderen bestaan uit massamediale campagnes. Deze zijn reeds beschreven in paragraaf 5.3.1. 


\section{Selectieve preventie van alcoholmisbruik en -afhankelijkheid bij volwassenen en ouderen}

\section{Website ‘drankjewel’, volwassenen (www.drankjewel.nl; Riper \& Conijn, 2003)}

De website is van het Trimbos-instituut.

- Doelgroep: Kinderen van ouders met alcoholproblemen. De site bestaat uit twee delen: één voor jonge en één voor volwassen kinderen van probleemdrinkers.

- Doel: Voorkomen van problemen als gevolg van de problematiek van de ouders, door kinderen te informeren en hen helpen om met hun problemen om te gaan.

- Methode: De website biedt informatie voor, over en door volwassen kinderen van ouders met alcoholproblemen. Bezoekers kunnen ervaringen uitwisselen via het forum en vragen stellen via e-mail of chatten met een deskundige.

- Ontwikkelingsfase: G. Drankjewel is sinds mei 2003 online.

- Aanbod en bereik: Het deel voor volwassenen is in 2005 maandelijks bezocht door 1200 (verschillende) bezoekers.

- Wetenschappelijke status: ${ }^{*}$.

\section{Geïndiceerde preventie van alcoholmisbruik en -afhankelijkheid bij volwassenen en ouderen}

'De Drinktest' (www.drinktest.nl; Huiberts \& Boon, 2003a, 2003b)

- Doelgroep: Volwassenen die regelmatig drinken en hun drinkgedrag willen analyseren.

- Doel: Informeren en adviseren van mensen die regelmatig alcohol drinken met een advies op maat.

- Methode: Zelftest op het internet voor volwassenen die regelmatig alcohol drinken. Op basis van het alcoholgebruik en andere indicatoren krijgen deelnemers een advies op maat. Indien gewenst kan de bezoeker via het internet doorschakelen naar een internsievere interventie, Minderdrinken (zie beneden).

- Ontwikkelingsfase: G.

- Aanbod en bereik: Drinktest wordt door het NIGZ aangeboden. In 2003 werden 280.000 bezoekers geregistreerd en werden circa 150.000 adviezen op maat gegeven.

- Wetenschappelijke status: ** (Huiberts \& Boon, 2003). Momenteel wordt opnieuw gerandomiseerd onderzoek gedaan naar de verbeterde versie van de interventie (Boon \& Huiberts, in voorbereiding).

Internet-zelfhulpcursus 'Minder drinken' (www.minderdrinken.nl; Riper et al., in voorbereiding).

- Doelgroep: Volwassen probleemdrinkers die graag zelfstandig willen minderen of stoppen met drinken zonder tussenkomst van een hulpverlener.

- Doel: Leren drinken binnen de limieten van verantwoord alcoholgebruik. Dit kan ook zijn het stoppen met drinken van alcohol.

- Methode: MinderDrinken bestaat uit een zelfhulpprogramma en een deelnemersforum. Het zelfhulpprogramma heeft cognitief-gedragstherapeutische uitgangspunten. De cursus bestaat uit drie stappen: 1) voorbereiden op het minderen of stoppen, 2) beslissen tot minderen/stoppen en daarbij doelen stellen en 3 ) het uitvoeren van het plan om te minderen of te stoppen. De vorderingen kunnen worden bijgehouden in een logboek met grafische weergave van de voortgang. Het deelnemersforum biedt de mogelijkheid om ervaringen uit te wisselen. Aangeraden wordt zes weken met het programma te werken.

- Ontwikkelingsfase: G.

- Aanbod en bereik: De site is voor iedereen vrij te bezoeken. 
- Wetenschappelijke status: ${ }^{* *}$. Het programma is op effectiviteit onderzocht in een gerandomiseerd onderzoek onder 268 personen die meer dronken dan de gangbare richtlijn voor verantwoord alcoholgebruik (Gezondheidsraad, 2005), en als zodanig een verhoogde risicostatus hebben (Riper et al., in voorbereiding).

Schriftelijke zelfhulpcursus 'Hoe minder te drinken' (van Emst, 1996)

- Doelgroep: Volwassen probleemdrinkers die zelfstandig iets aan het alcoholgebruik willen doen.

- Doel: Leren drinken binnen de limieten van verantwoord alcoholgebruik. Dit kan ook zijn het stoppen met drinken van alcohol

- Methode: In dit boekje wordt een gelijksoortige methodiek toegepast als in de internet-zelfhulpcursus 'MinderDrinken', maar dan in boekvorm.

- Ontwikkelingsfase: G. Het boekje is niet meer te bestellen bij het Trimbos-instituut. Een herziening van het boekje is wel beschikbaar: Minder Drinken (Lemmers et al., 2006).

- Aanbod en bereik: Deze zelfhulpgids vormt een onderdeel van de Teleac-serie: Minder Drinken? Doe het zelf! die in het najaar van 2006 zal worden uitgezonden.

- Wetenschappelijke status: * (Kramer \& Riper, 2005a).

\section{Teleac cursus 'Minder drinken: doe het zelf'}

- Doelgroep: Televisiekijkend Nederland, en dan vooral de mensen die veel drinken. Er wordt overigens niet geselecteerd: mensen kunnen zichzelf aanmelden. De cursus begint 20 november 2006.

- Doel: Mensen methoden aanreiken om zelf aan de slag te gaan met overmatig alcoholgebruik

- Methode: De televisiecursus is gebaseerd op diverse Minder Drinken interventies (zie boven) en loodst mensen stap voor stap door een gedragstherapeutische cursus. Dit gebeurt aan de hand televisieuitzendingen. Cursisten krijgen bovendien een cursusboek.

- Ontwikkelingsfase: I

- Aanbod en bereik: De cursus zal potentieel een groot publiek kunnen bereiken. Te zijner tijd is dit wellicht via kijkcijfers en de verkoop van cursusboeken te kwantificeren.

- Wetenschappelijke status: *. De interventie bouwt voort op vergelijkbare Minder Drinken interventies, maar het medium is anders en de doelgroep mogelijk ook. Voorafgaand aan de uitzending wordt door het Trimbos-instituut een gerandomiseerd effectonderzoek uitgevoerd. Dat onderzoek loopt nu.

\section{Groepscursus 'Educatieve Maatregel alcohol en verkeer' (Centraal Bureau Rijvaardigheid)}

In 1996 is de cursus ingevoerd door het Ministerie van Verkeer en Waterstaat.

- Doelgroep: bestuurders bij wie een alcoholpromillage werd gemeten tussen de 1,3 en 1,8 (in geval van herhaling een promillage van 0,8 ).

- Doel: Het voorkomen van (herhaling van) alcoholgebruik in het verkeer.

- Methode: Het betreft een bestuursrechterlijke maatregel die bestuurders verplicht deel te nemen aan een cursus. De cursus bestaat uit een individueel gesprek en een driedaagse cursus met als inhoud: informatie-overdracht, probleemerkenning en terugvalpreventie.

- Ontwikkelingsfase: De cursus wordt uitgevoerd door regionale instellingen voor de verslavingszorg in samenwerking met het CBR.

- Aanbod en bereik: Het bereik is $\mathbf{8 0 0 0 - 9 0 0 0 ~ d e e l n e m e r s ~ p e r ~ j a a r . ~}$

- Wetenschappelijke status: niet effectief: de cursus heeft weliswaar effecten op kennis, maar nauwelijks op gedrag (Nägele \& Vissers, 2000). 


\section{'Behandeling online' (www.brijder.nl)}

Dit is een kortdurende internetbehandeling die aangeboden wordt via de website van Brijder Verslavingszorg.

- Doelgroep: Volwassen probleemdrinkers die via internet willen minderen of stoppen met drinken onder begeleiding van een hulpverlener.

- Doel: Leren drinken binnen de limieten van verantwoord alcoholgebruik. Dit kan ook zijn het stoppen met drinken van alcohol.

- Methode: Leefstijltraining voor internet is een bewerking van Leefstijltraining 1, ontwikkeld in het kader van Resultaten Scoren. Met behulp van motiverende gesprekstechnieken en cognitief-gedragstherapeutische technieken wordt geleerd om weer verantwoord met alcohol om te gaan. De cursus bestaat uit; doelen stellen, risicosituaties analyseren, een noodplan maken, sociale steun organiseren, leren omgaan met terugval en doelen op de lange termijn formuleren.

- Ontwikkelingsfase: G.

- Aanbod en bereik: Leefstijltraining wordt via internet aangeboden door Brijder Verslavingszorg. Deelname is niet gratis, vergoeding kan via de zorgverzekering geregeld worden.

- Wetenschappelijke status: *.

\section{'Zelfhulpprogramma alcohol' (www.jellinek.nl/zelfhulp/alcohol)}

Dit is een internetbehandeling die binnenkort aangeboden wordt via De Jellinek.

- Doelgroep: Volwassen probleemdrinkers die via internet willen minderen of stoppen met drinken onder begeleiding van een hulpverlener.

- Doel: Leren drinken binnen de limieten van verantwoord alcoholgebruik. Dit kan ook zijn het stoppen met drinken van alcohol.

- Methode: De interventie bestaat uit de combinatie van een online zelfhulpprogramma en chatsessies met een hulpverlener. Na iedere stap krijgt de deelnemer gelegenheid om direct met een hulpverlener te chatten. In totaal bestaat de interventie uit 7 sessies.

- Ontwikkelingsfase: G.

- Aanbod en bereik: Jellinek start in november 2006 met het aanbieden van deze internetbehandeling.

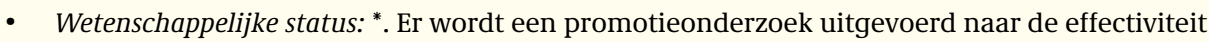
van de interventie.

\section{'Alcohol de Baas' (www.alcoholdebaas.nl)}

Dit is een kortdurende internetbehandeling die aangeboden wordt via Tactus, Instelling voor Verslavingszorg.

- Doelgroep: Volwassen probleemdrinkers die via internet willen minderen of stoppen met drinken onder begeleiding van een hulpverlener.

- Doel: Leren drinken binnen de limieten van verantwoord alcoholgebruik. Dit kan ook zijn het stoppen met drinken van alcohol.

- Methode: Alcohol de Baas is op dezelfde principes gebaseerd als de zelfhulpsite 'Minder Drinken'. Het programma wordt echter niet zelfstandig door deelnemers uitgevoerd maar onder begeleiding van een hulpverlener.

- Ontwikkelingsfase: G.

- Aanbod en bereik: Alcohol de Baas wordt aangeboden door Tactus, instelling voor verslavingszorg. Inschrijving is gratis.

- Wetenschappelijke status: *. Het programma wordt momenteel op effect onderzocht. 



\section{BIJLAGE 6 ECONOMISCHE EFFECTEN VAN PREVENTIE}

In de hoofdstukken 3, 4 en 5 werden schattingen gegeven van de te verwachten gezondheidswinst door het aanbieden van preventieve interventies. Daarnaast hebben deze interventies uiteraard ook gezondheidseconomische consequenties. Over de grootte van deze economische effecten is tot nu toe vrijwel niets bekend. Er zijn nog vrijwel geen kosten-effectiviteits analyses (KEA's) gedaan voor de preventie van psychische stoornissen (De Wit et al., 2006). Een recente KEA van de zelfhulpcursus met minimale begeleiding voor sombere huisartspatiënten (Smit et al., 2006b; tekstblok 3.1) vormt daarop een uitzondering.

In deze bijlage laten we zien hoe de economische consequenties bij afwezigheid van een KEA ook op een indirecte manier kunnen worden geschat, waarbij we cijfers uit diverse bestaande gezondheidseconomische bronnen combineren. Deze modelmatige aanpak is uiteraard afhankelijk van de betrouwbaarheid van de bronnen. In welke mate die betrouwbaarheid de uitkomsten beïnvloedt, wordt gekwantificeerd in gevoeligheidsanalyses.

We gebruiken twee gezondheidseconomische analyses om een indruk te krijgen van de kosten en effecten van preventie van psychische stoornissen.

- Kosten-effectiviteitsanalyse: hierbij zetten we de netto kosten (d.w.z. kosten van de interventie minus kostenbesparingen als gevolg van het vermijden van ziekten) af tegen de effecten. Hier zullen we als uitkomstmaat het aantal vermeden psychische stoornissen nemen. We berekenen dus de kosten per voorkomen psychische stoornis.

- Kosten-utiliteitsanalyse: in deze variant op kosten-effectiviteitsanalyse worden de effecten uitgedrukt in een meer algemene gezondheidsmaat, in dit geval het aantal vermeden DALY's (tekstblok 1.1). Net zoals bij kosten-effectiviteitsanalyse worden de netto kosten gerelateerd aan de effectmaat, hier dus het aantal vermeden of voorkomen DALY's.

Deze economische doorrekeningen worden uitgevoerd vanuit het zogenaamde maatschappelijk perspectief. Dat wil zeggen dat niet alleen wordt gekeken naar de directe zorgkosten die samenhangen met psychische stoornissen, maar dat ook kosten in andere sectoren van de samenleving, zoals reiskosten (die meestal gedragen worden door de patiënt zelf) en de kosten van ziekteverzuim. We onderscheiden de volgende kostenposten:

- directe medische kosten (de kosten van de preventieve interventie en de te voorkomen zorgkosten);

- directe niet-medische kosten (bijvoorbeeld de kosten die door de patiënt gedragen worden, zoals reiskosten);

- indirecte niet-medische kosten (productieverliezen door arbeidsverzuim als gevolg van ziekte). 
Beschouwing van al deze kostensoorten is van belang om na te kunnen gaan of een interventie kosteneffectief is, want wanneer alleen naar één kostensoort wordt gekeken, kunnen eventuele kostenverschuivingen (waarbij andere partijen kostendrager worden) aan het oog onttrokken worden. Net als in de rest van het rapport kozen we hier voor een tijdshorizon van één jaar. De kosten en baten hebben dus betrekking op één jaar, en worden daarom niet gedisconteerd of gecorrigeerd voor inflatie. Alle kosten worden uitgedrukt in euro voor het jaar 2003.

\section{Methoden}

Voor het berekenen van de kosten van psychische stoornissen waren twee verschillende bronnen beschikbaar: de Kosten van Ziekte studie (Slobbe et al., 2006) en een economische doorrekening op grond van Nemesis (Smit et al., in druk-b). Beide datasets hebben gemeen dat de beschikbare cijfers over zorggebruik en kosten gekoppeld zijn aan diagnoses of diagnosegroepen. In de KvZ-studie worden de totale kosten van de gezondheidszorg toegewezen aan diagnosegroepen. In Nemesis werd aan personen in een grote steekproef (ruim 7 duizend mensen) gevraagd welke zorg ze in het afgelopen jaar hebben ontvangen. Aan deze zorgcontacten zijn vervolgens kosten toegerekend (Oostenbrink et al., 2004). Omdat van alle respondenten ook de psychische diagnose wordt vastgesteld, kunnen zo de gemiddelde zorgkosten per diagnose worden berekend (Smit et al., in druk-b).

Voor onze berekeningen hebben we uiteindelijk gekozen voor de cijfers uit Smit et al. (in druk-b). Deze keuze is gebaseerd op de volgende argumenten. Allereerst beperkt de KvZ-studie zich tot de directe medische kosten, terwijl Smit et al. ook de overige kosten meenamen. Ten tweede zijn de kosten in de KvZ-studie gekoppeld aan brede stoornisgroepen en bleek het niet mogelijk om de kosten naar afzonderlijke diagnoses te berekenen. Zo zijn de kosten voor alcohol en drugs niet uit te splitsen. Tot slot wegen in de KvZ-studie de kosten van langdurige opnamen sterk mee in de gemiddelde kosten per capita. Dit zou mogelijk een overschatting geven van de effecten van preventie. Immers, we verwachten niet dat met een preventieve interventie in het eerste jaar dure psychiatrische ziekenhuisopnamen worden voorkomen. Omdat de Nemesis-studie zich beperkt tot de niet-geïnstitutionaliseerde Nederlandse bevolking is het aandeel van de opnamen in de kosten per stoornis veel lager dan in de KvZ data. Mede omdat dit beter bij onze onderzoeksvraag past hebben we ervoor gekozen om de data van Smit et al. te gebruiken.

Uiteraard heeft de Nemesis-studie ook beperkingen. Zo beperkt de studie zich tot personen tussen 18 en 64 jaar; jongeren en ouderen zijn uitgesloten. Daarnaast zijn de gerapporteerde kosten gebaseerd op door respondenten genoemde contacten met de zorg in het afgelopen jaar. Uit ander onderzoek is bekend dat dit waarschijnlijk een onderschatting geeft van het werkelijk aantal zorgcontacten.

Tabel B6.1 geeft de totale kosten per persoon met een bepaalde stoornis. De totale kosten bestaan uit een optelling van de kosten van zorggebruik (huisartscontact, gesprek met een psycholoog, enz.), de kosten die gemoeid zijn het verkrijgen van de zorg 
(reizen, parkeergelden, reis-, wacht- en behandeltijd), en de kosten die ontstaan door productieverliezen in betaalde arbeid door verzuim. Naast de totale kosten worden ook de betrouwbaarheidsintervallen rondom die kosten getoond. Het gaat hier bij om zogenaamde 'excess kosten', de meerkosten die toe te schrijven zijn aan de betreffende stoornis.

Tabel B6.1: Jaarlijkse per capita meerkosten (in euro's) van psychische stoornissen ( $N=5.491$; overgenomen uit Smit et al., in druk-b).

\begin{tabular}{lrrr}
\hline DSM-stoornis & Totaal & $95 \%$ BI van de totale kosten ${ }^{\text {a }}$ \\
\hline Enige stoornis & 3.200 & 2.117 & 4.284 \\
Stemmingsstoornis & 5.009 & 3.016 & 7.001 \\
$\quad$ Depressie & 2.278 & 331 & 4.225 \\
Dysthymie & 10.322 & 4.276 & 16.369 \\
Angststoornissen & 3.587 & 1.883 & 5.291 \\
Paniekstoornis & 8.390 & 2.772 & 14.008 \\
Agorafobie & 4.879 & -514 & 10.272 \\
Sociale fobie & 1.848 & -1.648 & 5.343 \\
Specifieke fobie & 2.372 & 167 & 4.578 \\
Gegeneraliseerde angststoornis & 917 & -3.444 & 5.279 \\
Alcoholgerelateerde stoornissen & 1.431 & -194 & 3.057 \\
Alcoholmisbruik & 923 & -887 & 2.733 \\
Alcoholafhankelijkheid & 2.509 & -1.023 & 6.041 \\
Basiskosten & 1.049 & 784 & 1.315 \\
\hline
\end{tabular}

a $95 \%$ betrouwbaarheidsintervallen gebaseerd op 1.000 bootstraps.

De besparingen per vermeden geval stellen we gelijk aan de per capita meerkosten van de betreffende stoornis in één jaar (zie tabel B6.1). Voor de respectievelijke stoornissen zijn dit:

- $€ 2.278$ bij depressie;

- $€ 3.587$ bij angststoornissen;

- $€ 1.431$ bij alcoholgerelateerde kosten (alcohol misbruik en afhankelijkheid)

Voor het berekenen van de kosten van interventies bestaan vaste afspraken tussen gezondheidseconomen (Oostenbrink et al., 2004). De directe medische kosten van een preventieve sessie worden hieronder met $€ 125$ hetzelfde gewaardeerd als de integrale behandelkosten van dagbehandeling bij de ambulante GGZ. Dit is hoger dan de € 88 voor een sessie ambulante behandeling bij een ambulante GGZ, maar de sessies van preventieve interventies duren meestal wat langer (Smit et al., in druk-b). De indirecte kosten zijn ook gebaseerd op de afspraken zoals vastgelegd in Oostenbrink et al. (2004), d.w.z. dat het ziekteverzuim gewaardeerd is volgens de frictiekostenmethode.

De totale kosten van de interventie worden berekend door uit te gaan van het aantal sessies waaruit de interventie bestaat en een intake-gesprek per deelnemer. De per capita kosten worden berekend als de totale kosten van de interventie gedeeld door het aantal deelnemers. 
De beschreven interventies zijn niet 100\% succesvol om het ontstaan van een stoornis te kunnen vermijden. Er moeten meer mensen deelnemen aan een interventie om bij één van hen het ontstaan van een stoornis te voorkomen. Bij het berekenen van de kosten per voorkomen geval nemen we de kosten van die andere deelnemers ook mee. Het exacte aantal deelnemers dat aan de interventie moet deelnemen om bij één van hen het ontstaan van de stoornis te voorkomen staat vermeld bij de onderzochte interventies in hoofdstuk 3, 4 en 5, als NNT (Numbers-Needed-to-be-Treated).

Voortbouwend op de berekening van de kosten per voorkomen psychische stoornis kan worden berekend hoeveel DALY's worden vermeden per voorkomen psychische stoornis (paragraaf 2.5). Gezien de tijdshorizon van één jaar laten we eventuele effecten op de levensduur buiten beschouwing. Voor de beschreven stoornissen zijn wegingsfactoren bekend die weergeven hoeveel de kwaliteit van leven wordt verminderd als gevolg van deze stoornis. Ook hier is één jaar de tijdshorizon.

Daarbij moet worden aangetekend dat veel van de beschreven stoornissen - en vooral angststoornissen en depressie - een episodisch verloop kennen. Dat wil zeggen dat de ziekte bestaat uit episoden van enkele maanden of jaren. Ook in het geval van een chronisch beloop is er vaak sprake van elkaar opvolgende episoden. Over de duur van de aparte episoden bij depressie is bekend dat deze gemiddeld een half jaar duren (Kruijshaar et al., 2004 ); bij paniekstoornis is dat acht maanden (Batelaan et al., 2006). In de DALY-wegingsfactoren die bekend zijn is de duur van de ziektes die minder dan een jaar duren al verrekend (door gebruik te maken van een maandprevalentie). Voor het berekenen van de impact van het voorkomen van individuele gevallen van psychische stoornissen op het aantal DALY's moest nog wel gecorrigeerd worden voor de duur van de episode van de stoornis.

\section{Gevoeligheidsanalyses}

De economische berekeningen zijn gebaseerd op schattingen; een gemiddelde waarde binnen een betrouwbaarheidsinterval. Dat betekent dat ook de uitkomsten niet als één vaststaand cijfer mogen worden geïnterpreteerd, maar ook weer als een waarde binnen een betrouwbaarheidsinterval. Om inzicht te geven in de breedte van dit interval hebben we gevoeligheidsanalyses uitgevoerd op de twee belangrijkste parameters: de kosten per voorkomen psychische stoornis en de NNT.

Voor een gevoeligheidsanalyse voor de te voorkomen kosten konden we eenvoudig gebruik maken van de 95\% betrouwbaarheidsintervallen van Smit et al. (tabel B6.1). Er kunnen geen gangbare 95\% betrouwbaarheidsintervallen berekend worden rondom NNTs. In plaats van een betrouwbaarheidsinterval nemen we daarom een lage en een hoge NNT-waarde, waarbij we rekening houden met de grootte van de studie; hoe groter de studie des te smaller het interval. Aan de hand van deze lage en hoge waarden in het betrouwbaarheidsinterval worden alle berekeningen opnieuw uitgevoerd. 


\section{Selectie interventies voor doorrekening}

De hierboven beschreven bronnen en berekeningswijzen stellen strenge eisen aan de beschikbaarheid van betrouwbare informatie over het effect van de preventieve interventies. We beperken ons hier daarom tot interventies waarvoor resultaten uit gerandomiseerd effect onderzoek bekend zijn en waar de incidentie van de betreffende stoornis als uitkomstmaat is gebruikt. In die onderzoeken moet incidentie zijn gebruikt als effectmaat omdat in de gehanteerde bronnen de kosten zijn gekoppeld aan diagnose. Bovendien moet de NNT bekend zijn. Tot slot laten we interventies gericht op jongeren en ouderen buiten beschouwing omdat deze groepen in Nemesis niet zijn meegenomen.

Het grootste deel van de in dit rapport beschreven interventies bleek niet geschikt voor zo'n economische doorrekening. Uiteindelijk bleven slechts twee interventies over: een eendaagse workshop ter voorkoming van paniekstoornis (paragraaf 4.4.2), en de zelfhulpcursus met minimale begeleiding 'In de put, uit de put' ter voorkoming van depressie bij huisartspatiënten (paragraaf 3.4.2). Voor deze laatste interventie is al eerder een kosten-effectiviteitsanalyse uitgevoerd (Smit et al., 2006b). Deze staat uitgebreid beschreven in tekstblok 3.1. In deze modelmatige berekening blijft deze interventie daarom buiten beschouwing.

\section{Doorrekening ééndaagse paniekworkshop}

Deze ééndaagse workshop is gericht op mensen die ooit een paniekaanval meemaakten. Doel is te voorkomen dat ze een paniekstoornis ontwikkelen. De interventie werd beschreven in paragraaf 4.4.2. Voor deze berekening gaan we uit van een intake en een dagdeel (het betreft immers een eendaagse workshop) voor tien deelnemers.

Per voorkomen geval van paniekstoornis wordt $€ 8390$ bespaard (zie tabel B6.1; 95\% BI $€-14.008-€-2.772)$. De totale directe medische kosten van de preventieve interventie bedragen $€ 1.750$, bestaande uit tien intakes van $€ 125$ (samen $€ 1.250$ ), en 4 uur maal $€ 125$ (samen $€ 500$ ) voor de cursus. De directe niet-medische kosten schatten we op $€ 100$ euro per deelnemer. De totale kosten van de workshop zijn dus $€ 2.750$ euro per cursus, dat is $€ 275$ per deelnemer. De effectiviteit van de interventie - uitgedrukt in NNT - is 8,4. Gezien het beperkte aantal deelnemers in het onderzoek, stellen we het betrouwbaarheidsinterval voor de NNT op 4 tot en met 12 .

De voorkomen kosten voor één paniekstoornis zijn $€$ 8.390. De kosten voor de benodigde 8,4 deelnemers aan de cursus zijn $(8,4 \times 280=) € 2.310$. De netto kosten zijn hier dus negatief (circa $€-6.000$ ), dat wil zeggen dat de interventie meer besparingen oplevert dan dat hij kost. Anders gezegd: de interventie levert naar schatting 6 duizend euro op per voorkomen geval. Uit de gevoeligheidsanalyse voor de te voorkomen kosten (tabel B6.2) blijkt dat het betrouwbaarheidsinterval in de bron (Smit et al., in druk), grote invloed heeft op de uitkomsten. Daarentegen heeft de onzekerheid rondom de NNT vrijwel geen invloed op de uitkomsten, omdat de kosten van de interventie relatief laag zijn (tabel B6.2). Een paar deelnemers meer of minder maakt voor de kosteneffectiviteit van deze workshop niet zo heel veel uit. 
Het voorkomen van een geval van paniekstoornis levert in het eerste jaar gedurende 8 maanden 0,17 DALY op. In totaal is dat 0,12 DALY per voorkomen geval. Daarmee komt de kosten-utiliteit op ( $€-6.000 / 0,12)$ een besparing van ongeveer $€-50.000$ per gewonnen DALY. Deze bevinding wordt door economen 'dominant' genoemd, dat wil zeggen dat het én kostenbesparingen oplevert én gezondheidswinst.

Tabel B6.2: Resultaten economische doorrekeningen ééndaagse paniekworkshop (in €), met twee gevoeligheidsanalyses; voor de spreiding in de kosten en de NNT.

\begin{tabular}{llll}
\hline & Resultaat & $\begin{array}{l}\text { Gevoeligheidsanalyse } \\
\text { voorkomen kosten }(95 \% \mathrm{BI})\end{array}$ & $\begin{array}{l}\text { Gevoeligheidsanalyse } \\
\text { NNT }(4-12)\end{array}$ \\
\hline Kosteneffectiviteit & $€-6.000$ & $(€-11.700-€-400)$ & $(€-7.200-€-5.100)$ \\
Kostenutiliteit & $€-50.000$ & $(€-97.500-€-3.300)$ & $(€-60.000-€-42.500)$ \\
\hline
\end{tabular}

We concluderen dat deze interventie binnen één jaar vrijwel zeker zowel gezondheidswinst als economische besparingen oplevert ten opzichte van een scenario van niets doen. De exacte besparing is moeilijk te bepalen, vooral door de brede betrouwbaarheidsintervallen in de te voorkomen kosten. 


\section{BIJLAGE 7 BELEIDSGESCHIEDENIS PREVENTIE VAN PSYCHISCHE STOORNISSEN}

In deze bijlage beschrijven we de landelijke beleidsgeschiedenis rond de preventie van psychische stoornissen vanaf 1995. De samenvatting van deze beleidsgeschiedenis staat in hoofdstuk 7, in paragraaf 7.2.3.

In deze bijlage worden de belangrijkste beleidsontwikkelingen van de afgelopen tien jaar besproken, per leeftijdsgroep - jeugd (paragraaf B7.1), volwassenen (B7.2) en ouderen (B7.3) -. Daarbij gaan we eerst in op beleidsvoornemens uit de vorige preventienota 'Langer gezond leven: ook een kwestie van gezond gedrag' (VWS, 2003a) of daarna, en vervolgens kijken we terug op de beleidsontwikkelingen die vooraf zijn gegaan aan de Preventienota. In paragraaf B7.4 stippen we kort de speerpunten van beleid ten aanzien van preventie van psychische stoornissen op Europees niveau aan.

\section{B7.1 Doelgroep jeugd}

\section{Beleidsvoornemens 2003 - 2006}

De eerste preventienota (VWS, 2003) noemt kinderen en jongeren als één van de twee belangrijkste doelgroepen, maar heeft voor deze leeftijdsgroep geen specifieke beleidsvoornemens geformuleerd over de preventie van psychische stoornissen. In de preventienota staat wèl dat de volgende psychische klachten met voorrang aangepakt moeten worden: depressie, angststoornissen, zelfdoding en alcoholverslaving (zie paragraaf 4.3.2: volwassenen). Deze klachten zijn echter niet aangemerkt als speerpunt.

Van de in dit rapport beschreven stoornissen heeft VWS alleen voor de preventie van overmatig alcoholgebruik bij jongeren beleidsdoelen geformuleerd (VWS, 2005a). VWS wil stimuleren dat a) kinderen zo laat mogelijk en het liefst niet onder de 16 jaar beginnen met drinken en b) jongeren boven de 16 jaar niet overmatig alcohol gebruiken.

Preventie van psychische problemen bij de jeugd staat ook in de beleidsagenda 2004 van het kabinet (VWS, 2003c). Het kabinet heeft geld uitgetrokken om het aanbod aan opvoedingsondersteuning te vergroten en intensieve gezinsbegeleiding mogelijk te maken. Daarmee wil het kabinet de vraag naar zwaardere zorg tegengaan. Daarnaast heeft zij ingezet op het versterken van samenhang in de keten van preventie naar zorg voor jeugdigen. Dit gebeurt via Operatie Jong (VWS, 2004b). Het doel van Operatie Jong is om uitval van jeugdigen zoveel mogelijk te voorkómen. Een van de twaalf thema's is vroegsignalering: adequaat inspelen op signalen van mogelijke ontsporing zoals frequent ziekteverzuim, plegen van delicten, depressie etc. De nadruk in dit jeugdbeleid ligt op het voorkómen van externaliserend gedrag en criminaliteit. Er is vrijwel geen specifieke aandacht voor preventie van de in dit rapport beschreven stoornissen. 


\section{Beleidsvoornemens 1995 - 2003}

De preventie van specifieke psychische stoornissen bij kinderen en jongeren komt nauwelijks voor in beleidsvoornemens van de afgelopen tien jaar. Wel is er aandacht voor preventie van ernstige problemen in het algemeen bij de jeugd. Volgens de nota Volksgezondheidsbeleid ‘Gezond en wel’ (VWS, 1995) richt het beleid zich op de jeugdgezondheidszorg en jeugdigen in achterstandssituaties. Het betreft een voortzetting van lopende activiteiten. Er staat niet beschreven welke activiteiten dit zijn. In de prebeleidsvisie GGZ (VWS, 1997c) staat dat de overheid streeft naar een samenhangend stelsel van jeugdzorg. Door meer samenhang in de jeugdgezondheidszorg wil de overheid voorkomen dat kinderen en jongeren gaan ontsporen.

In de Beleidsvisie GGZ (VWS, 1998) wordt genoemd dat het belangrijk is om aandacht te hebben voor vroegtijdige herkenning en signalering van psychische problematiek bij kinderen en jongeren door consultatiebureau's en onderwijsinstellingen. Ook wordt preventie van psychische problematiek bij jeugd genoemd als speerpunt voor kennisontwikkeling via ZonMw. De prioriteit ligt bij problemen in verband met (o.a. seksueel) geweld, kindermishandeling en pesten. In de Alcoholnota 2000-2001 (VWS, 2000f) zijn landelijke beleidsvoornemens geformuleerd voor de preventie van overmatig alcoholgebruik onder jongeren. Jongeren worden daarin als primaire doelgroep genoemd voor het terugdringen van overmatig alcoholgebruik. De overheid wilde vanaf 2002 investeren in alcoholvoorlichting in het basisonderwijs. Verder zijn er tot de preventienota 2003 geen beleidsvoornemens over de preventie van specifieke psychische stoornissen bij kinderen en jongeren.

Het streven naar samenhang in de jeugdgezondheidszorg blijft ook na 2000 een belangrijk beleidsonderwerp. Volgens de Zorgnota 2001 (VWS, 2000g) wordt geld ter beschikking gesteld om de samenhang in de jeugdgezondheidszorg te bevorderen. Kinderen van nul tot zes jaar in achterstandssituaties zijn daarbij een beleidsspeerpunt.

\section{B7.2 Doelgroep volwassenen}

\section{Beleidsvoornemens 2003 - 2006}

Volgens de preventienota Langer Gezond Leven (2003a) moet de preventie van depressie, angststoornissen, zelfdoding en alcoholverslaving met voorrang aangepakt worden. Echter, geen van deze stoornissen wordt vermeld als speerpunt voor preventie.

Voor preventie van overmatig alcoholgebruik en van depressie zijn specifieke beleidsvoornemens geformuleerd. Voor alcoholproblematiek is het streven om het percentage probleemdrinkers van 16 jaar en ouder in 2004 laten dalen van negen naar acht procent; daarna wordt een streefcijfer voor de langere termijn vastgesteld. Voor depressie is het streven om het bereik van preventieve maatregelen te vergroten, zowel binnen de GGZ-instellingen als daarbuiten. Dit zou bereikt moeten worden door vroegtijdige inzet van minimale interventies via GGD-en, scholen, thuiszorg, bedrijfsgezondheidszorg en de eerstelijnszorg. Ook wil VWS ingrijpen op een specifieke risicofactor van depressie, namelijk het aanpakken van huiselijk geweld. 
Voor preventie van burnout heeft VWS geen beleidsvoornemens geformuleerd in de preventienota. Er staat echter wel in dat het belangrijk is om tijdig te signaleren en in te grijpen als sprake is van werkgerelateerde psychische klachten. Oorzaken van nietmedische aard, zoals conflicten op het werk, moeten volgens de preventienota op tijd worden aangepakt om te voorkomen dat hierdoor psychische problemen ontstaan. Ook wordt beschreven welke activiteiten er al zijn om werkgerelateerde psychische klachten terug te dringen. Deze activiteiten betreffen vooral wetenschappelijk onderzoek en ontwikkeling van interventies en richtlijnen.

Het Ministerie van Sociale Zaken en Werkgelegenheid (SZW) heeft evenmin beleidsvoornemens vastgelegd voor preventie van burnout. De minister van SZW geeft wel een overzicht van activiteiten die in 2005 op het gebied van arbeidsgerelateerde psychische problematiek bestonden. Dit overzicht staat in een beleidsbrief 'Arbeidsgehandicapten en reïntegratie' (SZW, 2005). Daarin concludeert SZW dat werkgevers en werknemers dankzij het werk van de subcommissie Psychische Problematiek (SPP) anders zijn gaan denken over de aanpak van ziekteverzuim wegens psychische problemen (zie 'ontwikkelingen vanaf 1995'). Ook heeft de SPP een Leidraad 'Aanpak verzuim om psychische redenen' geïmplementeerd onder professionals.

Daarnaast heeft SZW in arboconvenanten afspraken gemaakt met werknemers en werkgevers over werkgerelateerde psychische belasting (stress). De nadruk ligt daarbij op preventie van ziekteverzuim door het verbeteren van de arbeidsomstandigheden. Preventie van ziekteverzuim door het verminderen van psychische belasting komt in 18 van de 57 bestaande arbeidsconvenanten voor. Deze zijn verspreid over zeven branches. De invulling van de afspraken verschilt tussen de convenanten.

Voor angststoornissen zijn geen beleidsvoornemens geformuleerd.

\section{Beleidsvoornemens 1995 - 2003}

In de eerste beleidsnota's vanaf 1995 wordt preventie van psychische stoornissen slechts zijdelings genoemd. In de nota Volksgezondheidbeleid 1995-1998 'Gezond en Wel' (VWS, 1995) staat dat het beleid zich richt op voortzetting van lopende activiteiten op het gebied van preventie van alcoholmisbruik en van psychosociale problemen en depressie. Welke activiteiten dit zijn staat er niet bij. De nota Preventiebeleid Volksgezondheid (1997a) geeft een voortgangsrapportage van beleidsvoornemens uit de nota 'Gezond en Wel'. Daarin staat onder andere dat VWS bij onderzoeksprogrammering ten aanzien van preventie de prioriteit legt bij preventieve geestelijke gezondheidszorg. Ook wil VWS de landelijke sturing en coördinatie van GGZ-preventie versterken. Tevens zijn er in 1995 PreventieOntwikkelingsProjecten gestart met als thema GGZ-preventie. Tenslotte is de oprichting van het Trimbos-instituut genoemd, met als onderdeel landelijke ondersteuning preventie-GGZ, de huidige Landelijke Steunfunctie Preventie. Preventie van psyschische stoornissen betreft in deze nota dus voornamelijk onderzoek en ontwikkeling. In de beleidsbrief over openbare GGZ (VWS, 1997d) staat alleen dat preventie op het gebied van de openbare GGZ moet worden gestimuleerd. 
In de pre-beleidsvisie GGZ (VWS, 1997c) wordt preventie van psychische stoornissen alleen vermeld voor werkgerelateerde psychische klachten. Het beleidsvoornemen van VWS was om een landelijk debat te initiëren over preventie van en hulpverlening bij verzuim om psychische redenen.

In de Beleidsvisie GGZ (VWS, 1998) krijgt preventie van psychische stoornissen meer aandacht. Een van de beleidsvoornemens van VWS is dat de GGZ zich uitdrukkelijker moet gaan profileren op preventie, vroege opsporing en signalering, facetbeleid een geestelijk volksgezondheidbeleid. Het beleid zou zich onder meer moeten richten op het onderzoeken van oorzaken van psychische problematiek en op het voorkomen van die problemen. In de beleidsvisie staan de volgende speerpunten voor geestelijk volksgezondheidbeleid en preventie:

1. instellen van een commissie ter verbetering geestelijke volksgezondheid door overheid en maatschappelijke organisaties;

2. regiefunctie versterken via een coördinatieplatform GGZ-preventie;

3. oormerken van budgetten voor preventie;

4. kennisontwikkeling via ZonMW over onder andere depressie, angst en alcoholafhankelijkheid;

5. implementatie van effectieve programma's.

In de beleidsvisie GGZ heeft VWS ook een speerpunt opgenomen over psychische arbeidsongeschiktheid: VWS heeft samen met SZW een actieplan opgesteld voor de aanpak van ziekteverzuim om psychische redenen. Preventie van arbeidsgerelateeerde psychische problematiek krijgt daarbij speciale aandacht. Het voornemen van VWS was om het actieplan in 1999 via een landelijke conferentie te bespreken met alle betrokken partijen. De doelstelling was om afspraken te maken tussen deze partijen over verantwoordelijkheden, samenwerking en deskundigheidsbevordering.

In januari 1999 verscheen het 'Ontwikkelingsplan preventie geestelijke volksgezondheid en verslaving' (Dekker, 1998). VWS heeft dit document als referentie gebruikt voor de beleidsvisie GGZ (VWS, 1998). Het ontwikkelingsplan verscheen als reactie op een besluit van de beleidsdirectie Geestelijke gezondheid, Verslaving en Maatschappelijke ondersteuning (GVM) om aan preventie van GGZ geen prioriteit meer te verlenen. De maatschappelijke signalen op dit besluit waren zo krachtig en omvangrijk dat VWS besloten heeft om bovengenoemd ontwikkelingsplan op te stellen. Dit document bevat een voorstel om het beleid van VWS gericht op GGZ-preventie te intensiveren. De kernaanbevelingen waren:

- landelijk geldende inhoudelijke prioriteiten voor preventie op het gebied van GGZ en verslaving;

- de keuze van prioriteiten moeten gebaseerd zijn op de omvang en ernst van het gezondheidsprobleem;

- wijzigen van de financieringswijze van de GGZ-preventie en de ambulante verslavingszorg. Dit is een basale voorwaarde voor de versterking van preventie;

- versterken van de regiefunctie van VWS, meer aandacht besteden aan alcoholbeleid en preventie op het gebied van de geestelijke volksgezondheid. 
Naar aanleiding van deze kernaanbevelingen zijn versterking van GGZ-preventie en beperking van het gebruik van alcohol en drugs als beleidsdoelen opgenomen in de Regeringsverklaring.

\section{Specifieke psychische stoornissen}

Over specifieke psychische stoornissen bij volwassenen zijn alleen beleidsvoornemens geformuleerd ten aanzien van overmatig alcoholgebruik en psychische arbeidsongeschiktheid. Aan depressie en angststoornissen is tot aan de preventienota niet specifiek aandacht besteed in het landelijke beleid.

De Alcoholnota (VWS, 2000f) noemt als de belangrijkste primaire doelgroep van beleid voor preventie van overmatig alcoholgebruik (ex-)probleemdrinkers, naast jongeren. VWS streeft naar een verlaging van het percentage probleemdrinkers van $9 \%$ in 2000 naar $8 \%$ in 2004. De doelstelling is het bevorderen van alcoholmatiging en het beperken van het risico op alcoholgerelateerde problemen in specifieke situaties. VWS wil daartoe de volgende beleidsinstrumenten inzetten: landelijke publieksvoorlichting en voorlichting in het onderwijs, voorlichting voor verstrekkers van alcohol over wet- en regelgeving, wijziging van de drank- en horecawet, betere handhaving van de Dranken Horecawet, monitoring van zelfregulering, aanpassen etiketteringsregels, accijnsheffing. Ook wil VWS de herkenning van alcoholproblemen in de eerstelijn en het ziekenhuis verbeteren en de samenwerking tussen de eerstelijn en de verslavingszorg verbeteren.

Zowel het Ministerie van VWS als het ministerie van Sociale Zaken en Werkgelegenheid (SZW) hechten al een aantal jaren belang aan preventie van werkgerelateerde psychische klachten (tekstblok 7.1). Voor de periode van januari 2000 tot en met januari 2003 hebben deze twee ministeries de Commissie Psychische Arbeidsongeschiktheid (CPA) ingesteld. Doel van de CPA was om het proces rondom uitval van arbeid om psychische redenen te verbeteren. Hieruit is een Leidraad 'Aanpak verzuim om psychische redenen' ontstaan (CPA, 2001). Deze Leidraad beoogt om een bepaalde manier van werken te stimuleren die tot werkhervatting en herstel kan leiden. De CPA is op verzoek van VWS en SZW na januari 2003 blijven voortbestaan als de subcommissie Psychische problematiek (SPP). Deze subcommissie was onderdeel van de nieuw ingestelde Commissie het Werkend Perspectief (CWP). De SPP heeft zich vooral toegelegd op het implementeren van de Leidraad. Deze commissie heeft voortbestaan tot 1 januari 2005.

In juli 2003 verscheen er een brief van SZW aan de Tweede Kamer waarin de ernst van het probleem van psychische vermoeidheid en burnout werd benadrukt (SZW, 2003). Deze brief was een reactie op een advies dat de Raad voor Maatschappelijk Onderzoek (RMO) over burnout in 2002 heeft uitgebracht. De RMO gaf in het advies twee algemene oplossingsrichtingen aan voor de aanpak van burnout. De één is gericht op een betere afstemming tussen werk en persoon, de andere op een betere afstemming tussen werk en privé. In haar beleidsbrief onderschreef het kabinet deze invalshoek. Ook is beschreven op welke manier het kabinet al acties in die richting had onder- 
nomen. Daarnaast pleit het kabinet in de beleidsbrief voor aanvullende acties, met name het streven naar een omslag in de cultuur binnen organisaties en bedrijven. Daarbij zou de aandacht voor de werknemer als mens centraal moeten staan. Suggesties die het kabinet hiervoor geeft zijn: 1) stimuleren dat arboconvenanten aansluiten bij het RMO-advies van de RMO (tekstblok 7.1); 2) opname van het RMO-advies in de Meerjarenstrategie Psychosociale Arbeidsbelasting en RSI; 3) voorleggen RMO-advies aan de Commissie het Werkend Perspectief (CWP); 4) steunen van initiatieven in de bedrijfsgezondheidszorg die erop gericht zijn om de preventieve aanpak van burnout te bevorderen.

\section{B7.3 Doelgroep ouderen}

\section{Beleidsvoornemens 2003 - 2006}

In de preventienota uit 2003 worden ouderen niet als primaire doelgroep genoemd. Preventie bij ouderen wordt wel vermeld in een rapport uit 2005 van de themacommissie Ouderenbeleid. Daarin staat dat er meer geld geïnvesteerd moet worden in preventie, maar deze aanbeveling betrof niet specifiek preventie van psychische stoornissen. Alleen in de conclusieparagraaf staat dat er meer aandacht nodig is voor tijdige diagnosestelling en behandeling van depressies en angststoornissen.

\section{Beleidsvoornemens 1995 - 2003}

In 1996 is een beleidsbrief Modernisering ouderenzorg (VWS, 1996) uitgebracht. Het is een reactie op de adviezen van de voormalige Nationale Raad voor de Volksgezondheid, nu de Raad voor de Volksgezondheid en Zorg (RVZ). De beleidsbrief heeft specifiek betrekking op psychische problematiek bij ouderen vanaf 65 jaar. De beleidsvoornemens zijn vooral gericht op zorg, en slechts in de zijlijn op preventie. Een van de voornemens was om kwaliteits- en doelmatigheidswinst te behalen binnen de ouderenzorg door onder andere preventie te versterken. De rol van de rijksoverheid hierbij zou vooral stimulerend en voorwaardenscheppend moeten zijn.

Volgens de beleidsbrief stond de overheid in 1996 voor de keuze tussen ofwel het ontwikkelen van nieuwe preventieactiviteiten ofwel het implementeren van ontwikkelde GGZ-preventieprogramma’s. Hierover heeft de RVZ in augustus 1996 een vervolgadvies uitgebracht. De belangrijkste aanbevelingen betroffen de opzet en inhoud van een meerjarig landelijk preventieprogramma voor ouderen en het stimuleren van een samenhangend preventiebeleid op het lokale/regionale niveau. Op grond van dit advies heeft VWS haar beleidsvoornemen hierover in maart 1997 in een nieuwe beleidsbrief uiteengezet (VWS, 1997b). Het voornemen was om de aanbevelingen uit het advies van de RVZ in te passen in een preventieprogramma dat medio 1997 bij Zorg Onderzoek Nederland (ZON) van start zou gaan. Hiervoor heeft VWS gedurende vijf jaar anderhalf miljoen gulden op jaarbasis beschikbaar gesteld.

Het ZON-preventieprogramma betrof een vijfjarig projecten- en onderzoeksprogramma met drie deelprogramma's: onderzoek naar nieuwe preventiemethoden, effectiviteits- en doelmatigheidsonderzoek en implementatie-onderzoek. VWS wilde onder 
andere ruime aandacht besteden aan het bevorderen van een samenhangend lokaal/ regionaal preventief ouderenbeleid, en aan het voorkómen en vroegtijdig signaleren van depressie. Deze thema's zouden voor ouderen zeer belangrijk zijn en veel mogelijkheden bieden voor preventie. Voor preventie van depressie wilde VWS met name evaluatie- en effectonderzoek stimuleren, evenals de verdere uitbouw van veelbelovende in ontwikkeling zijnde programma's. Aandachtspunten daarbij zouden zijn de toepasbaarheid en implementatie op lokaal niveau en het formuleren van criteria van succesvolle preventie. Ook vroeg VWS aandacht voor de overdracht van verworven kennis over preventie van depressie op huisartsen, omdat zij als poortwachter een belangrijke functie hebben bij het signaleren van depressies. Het opstarten van nieuwe preventieprojecten kreeg geen prioriteit.

De nota over het preventiebeleid Volksgezondheid van 1997 wijdt een aparte paragraaf aan het belang van vroegtijdig opsporen van psychogeriatrische problemen bij ouderen, met name door middel van vroegdiagnostiek bij de huisarts.

Bijlage 2 van de Zorgnota 2001 (VWS, 2000e) geeft beleidsthema's in de programmering van onderzoek en ontwikkeling (PEO-beleid, oftewel beleid gericht op projecten, experimenten en onderzoek). De bijlage geeft geen beleidsvoornemens, maar wel een overzicht van projecten die bij de PEO-beleidsthema's horen. Een van de thema's is 'Ouderen', met psychische problemen van ouderen als speerpunt. Het ZON-programma 'Preventie van psychische en gedragsproblemen' vraagt aandacht voor het feit dat veel ouderen helemaal geen hulp ontvangen voor hun psychische klachten, doordat ze deze klachten bagatelliseren, ontkennen of somatiseren. Dit programma bevatte projecten op het gebied van preventie van depressie en angststoornissen, dementiesyndroom en rouwverwerking.

\section{B7.4 Internationaal beleid van preventie van psychische stoornissen}

Psychische gezondheid heeft speciale aandacht van de Europese Commissie. Zij heeft de preventie van psychische stoornissen als beleidsprioriteit opgenomen in haar actieprogramma voor publieke gezondheid 2003-2008 (zie Jané-Llopis \& Hosman, 2005). Via allerlei beleidsdocumenten roept de Europese Commissie alle lidstaten op om beleid te ontwikkelen voor psychische gezondheid. De belangrijkste speerpunten daarbij zijn:

- kwalitatief goede en voor iedereen toegankelijke zorg voor mensen met psychische problemen;

- aanpakken van stigmatisering en discriminatie van mensen met psychische problemen;

- betere informatiebasis creëren voor effectieve en kosteneffectieve interventies;

- financiering van psychische gezondheid beschermen, onder andere door oormerken van budgetten;

- preventie van suïcide;

- focus van zorg meer leggen bij eerstelijns gezondheidszorg en community centers;

- grotere betrokkenheid van patiënten en hun familie bij alle aspecten van de zorg; 
- richten op kwetsbare groepen;

- stimuleren van preventie en herkennen van risicofactoren door publieke gezondheidsinitiatieven.

Een van de belangrijkste projecten om bovengenoemde speerpunten te bereiken is het IMHPA-project (IMHPA, 2006). IMHPA heeft in 2004 een actieplan opgesteld om de bevordering van psychische gezondheid te implementeren in Europese landen. Het project loopt in 28 landen.

Vergeleken met andere Europse landen ligt de focus van het preventiebeleid in Nederland wat meer op het voorkómen van psychische stoornissen. In veel andere Europese landen ligt de focus sterker op het bereiken van een goede psychische gezondheid. De sociaal-economische status is daarbij een belangrijke determinant voor psychische gezondheid. Ook is het in andere landen niet altijd logisch dat preventieve interventies naast gezondheidswinst ook economische voordelen opleveren. Wel worden kostenbaten analyses of kosteneffectiviteitsstudies in veel landen als argument gebruikt om een belangrijke interventie grootschalig in te voeren (De Hollander et al., 2006). 


\section{BIJLAGE 8 ORGANISATORISCHE CONTEXT VAN PREVENTIE VAN PSYCHISCHE STOORNISSEN}

In paragraaf 7.2 is een korte schets gegeven van de beleidsmatige en organisatorische context ten behoeve van preventie van psychische stoornissen. In deze bijlage gaan we hier wat dieper in. We beschrijven hoe preventie van psychische stoornissen binnen de gezondheidszorg is georganiseerd: welke hulpverleners en instellingen houden zich bezig met de uitvoering van interventies gericht op preventie van psychische stoornissen? Daarbij kijken we uiteraard naar preventieve activiteiten in het algemeen, maar we leggen de nadruk op het type preventieve interventies zoals deze in hoofdstuk 3, 4 en 5 zijn beschreven. De wettelijke kaders en financiering zijn al uitgebreid besproken in paragraaf 7.2.2 en vormen geen onderwerp van deze bijlage.

In aansluiting op paragraaf 7.2 beschrijven we de verschillende vormen van preventie (universeel, selectief en geïndiceerd) binnen de gezondheidszorg volgens een indeling in drie verschillende deelterreinen: nuldelijns gezondheidszorg (GGD-en, thuiszorg, paragraaf B8.1), eerstelijns gezondheidszorg (huisarts, bedrijfsarts, algemeen maatschappelijk werk; B8.2) en tot slot de tweedelijns gezondheidszorg (GGZ-instellingen inclusief instellingen voor de verslavingszorg; B8.3). De openbare gezondheidszorg vormt - samen met settings buiten de gezondheidszorg (bijvoorbeeld scholen, werk) - de nuldelijn. Deze indeling is mede gebaseerd op het principe van de getrapte zorg. De lichtste en minst specialistische vorm van zorg gebeurt binnen de openbare gezondheidszorg. Dit veld is zeer breed en omvat die onderdelen van de gezondheidszorg die zich richten op de ziektepreventie en de bescherming en bevordering van de gezondheid van de gehele bevolking (Jansen, 2006). De eerstelijn omvat alle niet-gespecialiseerde voorzieningen die primair op een individu zijn gericht. De tweedelijn omvat alle specialistische voorzieningen. Kanttekening bij de gehanteerde indeling is dat veel actoren in meer dan één deelterrein actief zijn, waarbij ze ook weer per deelterrein een andere rol kunnen vervullen (paragraaf 7.2.1).

\section{B8.1 Nuldelijns gezondheidszorg}

De onderstaande informatie over preventie van psychische stoornissen in de nuldelijns gezondheidszorg is afkomstig van het Nationaal Kompas Volksgezondheid (www.nationaalkompas.nl). Voor meer informatie verwijzen we daarom naar deze website.

Preventie is één van de kerntaken van de openbare gezondheidszorg. Preventie van psychische stoornissen bestaat daarbij voornamelijk uit universele en selectieve preventie. De meeste activiteiten zijn gericht op de gehele bevolking en op mensen met een verhoogd risico op psychische klachten. Een klein deel van de preventieactiviteiten betreft geïndiceerde preventie en is gericht op mensen die al psychische klachten hebben, maar nog niet zoveel dat er sprake is van een psychische stoornis. 
Preventie van psychische stoornissen vindt vooral plaats binnen de openbare GGZ en de jeugdgezondheidszorg. Hiervoor zijn gemeenten verantwoordelijk. Preventie in de jeugdgezondheidszorg bestaat uit opgroei- en opvoedingsondersteuning van kinderen en jongeren van nul tot en met achtien jaar. Dit gebeurt zowel in de setting van het gezin als op scholen. Preventie binnen de openbare GGZ is onder andere gericht op riskant genotmiddelengebruik bij de jeugd en op vereenzaming bij ouderen (Ruiter et al., 2005).

Belangrijke uitvoerders van preventieve activiteiten in de openbare gezondheidszorg zijn GGD-en (www.ggd.nl, 2006). Alle GGD-en voeren minimaal de in de WCPV omschreven taken uit (paragraaf 7.2.2). Zo brengt elke GGD de gezondheidssituatie van de gemeentelijke bevolking in kaart, stemt preventie en curatieve zorg op elkaar af en coördineert de uitvoering van preventieprogramma's. Dit zijn onder andere psychoeducatieprogramma's en specifieke lesprogramma's gericht op bepaalde thema's. De daadwerkelijke uitvoering van preventieprogramma's gericht op psychische stoornissen gebeurt vaak door de preventieafdelingen van GGZ-instellingen.

Daarnaast voert iedere GGD voor zijn gemeente specifieke opdrachten uit. Die opdrachten staan beschreven in de gemeentelijke nota's over het lokale beleid volksgezondheid. Deze zijn niet voor elke GGD hetzelfde. Zo coördineert elke GGD de uitvoering van preventieprogramma's, maar welke programma’s dat zijn verschilt tussen gemeenten. Sommige gemeenten kiezen bijvoorbeeld voor een programma op scholen om de sociaal-emotionale ontwikkeling van kinderen en jongeren te bevorderen, terwijl andere gemeenten prioriteit geven aan een programma om schadelijk alcoholgebruik onder jongeren te voorkomen (zoals de Gezonde School en Genotmiddelen; www.dgsg.nl).

GGD-en werken samen met allerlei lokale en regionale organisaties en met zorgaanbieders uit de eerste- en tweedelijn. Bij taken gericht op preventie van psychische problemen werken GGD-en bijvoorbeeld samen met preventiewerkers uit de tweedelijns GGZ.

Binnen de openbare gezondheidszorg vindt naast universele en selectieve preventie ook geïndiceerde preventie van psychische stoornissen plaats. Het gaat dan om vroegherkenning en vroegbehandeling van psychische problemen. GGD-en coördineren deze vorm van preventie en voeren de activiteiten vaak ook zelf uit. Dit gebeurt door hulpverleners werkzaam bij GGD-en, zoals jeugdartsen, jeugdverpleegkundigen of gedragswetenschappers. De belangrijkste settings zijn consultatiebureau's en scholen.

\section{B8.2 Eerstelijns gezondheidszorg}

Eerstelijns zorgaanbieders die te maken hebben met psychische problematiek zijn de huisarts, sociaal-psychiatrisch verpleegkundige in de huisartspraktijk, het algemeen maatschappelijk werk (AMW), de eerstelijnspsycholoog en de bedrijfsarts. Voor ouderen spelen daarnaast de thuiszorg en de stichtingen Welzijn Ouderen een belangrijke 
rol. Op de grens tussen eerste- en tweedelijn speelt voor kinderen en jongeren Bureau Jeugdzorg een rol.

\section{Huisarts en sociaal-psychiatrisch verpleegkundige}

In de meeste gevallen is de huisarts de eerste zorgaanbieder waar mensen met psychische klachten binnen de eerstelijn hulp zoeken. Hij heeft daarom een belangrijke rol bij het vroegtijdig herkennen en behandelen van psychische problematiek.

Bij de behandeling van lichte psychische klachten zou de huisarts volgens de richtlijnen zich in de eerste instantie moeten beperken tot ondersteundende gesprekken of 'watchful waiting' (CBO / Trimbos-instituut, 2005; Van Marwijk et al., 2003). Dit laatste houdt in dat de huisarts een afwachtend beleid voert waarin hij niet meteen behandelt, maar wel bij de patiënt betrokken blijft en het verloop van de klachten via controleconsulten in de gaten houdt. Als de klachten binnen een vastgestelde tijd niet verdwijnen komen andere mogelijkheden in aanmerking. In de dagelijkse praktijk zijn dat vooral behandelopties zoals het voorschrijven van medicatie, of doorverwijzen naar een andere GGZ-hulpverlener in de eerstelijn of de gespecialiseerde GGZ. Voor mensen met beginnende klachten kunnen deze opties te zwaar zijn; in dat geval leiden ze tot onnodige medicalisering.

Systematische vormen van geïndiceerde preventie voor psychische klachten worden door de huisartsen zelf vrijwel niet aangeboden. Het ligt echter ook niet voor de hand om dat van huisartsen te verwachten. De huisartsen hebben er geen tijd voor, en ze missen daarvoor de specifieke kennis en vaardigheden (Visscher et al., 2002).

Een deel van de huisartsen heeft hulp in zijn praktijk van een sociaal-psychiatrisch verpleegkundige (SPV) uit de gespecialiseerde GGZ. Een SPV adviseert de huisarts over doorverwijzing van patiënten met psychische problematiek en kan een kortdurende behandeling geven aan patiënten met milde psychische klachten. In feite is dit laatste een vorm van geïndiceerde preventie. SPV-en maken echter nog vrijwel geen gebruik van de systematische vormen van geïndiceerde preventie. De functie van SPV binnen een huisartspraktijk is sterk in ontwikkeling en wordt door huisartsen verschillend vorm gegeven (Scholten et al., 2003 en 2005; Verhaak et al., 2005). De aanwezigheid van een SPV in de huisartspraktijk is nog niet structureel ingebed in alle huisartspraktijken, en er bestaat nog geen heldere functie-omschrijving voor een SPV in deze setting.

\section{Algemeen maatschappelijk werk}

Een van de functies van het AMW is 'bijdragen aan preventie van gezondheids- en welzijnsproblemen door voorlichting, en door training van psychosociale competenties van cliënten' (MO Groep, 2003). Het AMW biedt bijvoorbeeld verschillende groepstraingen en -cursussen aan, zoals een cursus rouwverwerking, bevorderen van zelfvertrouwen en assertiviteit, en een cursus verminderen van psychosociale klachten bij allochtone vrouwen (Trimbos-instituut / MO Groep, 2004). Ook hebben een aantal AMW-instellingen op projectbasis een cursusaanbod voor geïndiceerde preventie van 
depressie. De cursus wordt gegeven door een GGZ-hulpverlener of een AMW-er. Het project wordt in samenwerking met het Trimbos-instituut uitgevoerd en gefinancierd door ZonMw. Deelname van de AMW-instellingen aan dit project is op vrijwillige basis. De groepscursussen worden niet structureel bij alle AMW-instellingen aangeboden, en het aanbod wisselt per instelling. Het AMW werkt samen met hulpverleners uit de eerste- en tweedelijns GGZ, en met hulpverleners uit de openbare GGZ.

\section{Eerstelijnspsychologen}

Een eerstelijnspsycholoog biedt generalistische hulp aan mensen met klachten van psychische of psychosomatische aard. De aanpak kenmerkt zich door uitgebreide diagnostiek en kortdurende behandelingen. Een eerstelijnspsycholoog bereikt naar verhouding veel mensen uit de hogere sociaal-economische groepen. Naast behandeling en zorg behoort ook preventie tot hun doelstellingen (LVE, 2005). Het is onbekend in hoeverre eerstelijnspsychologen gestandaardiseerde preventieve interventies uitvoeren.

\section{Bedrijfsartsen}

Bedrijfsartsen hebben een belangrijke taak in de preventie van arbeidsgerelateerde psychische klachten. De bedrijfsarts beschermt, bewaakt en bevordert de gezondheid van werknemers, waaronder de psychische gezondheid. Hiertoe behoort ook het opsporen van risico's voor ziekten en het tijdig signaleren van beroepsziekten. De preventieve taken voert hij zowel uit bij individuele werknemers als op bedrijfsniveau. Bij individuele werknemers adviseert hij persoonlijk over gezond werken, en hij adviseert en begeleidt hen bij ziekteverzuim en terugkeer naar het werk. Ten aanzien van werkgerelateerde psychische klachten is de werkwijze van bedrijfsartsen vastgelegd in een richtlijn Psychische Klachten (NVAB 2000). Ook voor depressie, angststoornissen en overspannenheid zijn richtlijnen voor de bedrijfsarts opgesteld (NVAB, 2006). Op bedrijfsniveau adviseert hij directie en personeelsvertegenwoordiging over verbeteringen in de arbeidsomstandigheden en over mogelijkheden om beroepsziekten te voorkomen en beperken (www.arbodienst.com). Op bedrijfsniveau houdt hij zich dus vooral bezig met universele preventie, op individueel niveau gaat het meestal om geindiceerde preventie. Bedrijfsartsen werken samen met deskundigen binnen en buiten de Arbodiensten, waaronder het bedrijfsmaatschappelijk werk, huisarts en GGZ-hulpverleners.

\section{Bureau Jeugdzorg}

Bureau Jeugdzorg is de toegangspoort tot de hele jeugdzorg, waaronder jeugdhulpverlening. De kerntaak van Bureau Jeugdzorg ligt bij indicatiestelling. Ze stelt vast welke zorg minderjarigen met opgroeiproblemen of ouders met opvoedingsproblemen nodig hebben, begeleidt hen, of verwijst hen door naar andere hulpverleners (VWS \& VNG, 2004; www.bureaujeugdzorg.info/Informatie). Bureau Jeugdzorg heeft veel raakvlakken met de gemeentelijke jeugdgezondheidszorg.

Naast indicatiestelling houdt Bureau Jeugdzorg houdt zich ook bezig met preventie van psychische problematiek. Dit doet ze via het ondersteunen van preventieve lokale voor- 
zieningen voor jeugdigen. Ze draagt bij aan de deskundigheidsbevordering en advisering van beroepskrachten van lokale voorzieningen, zoals leerkrachten, jeugdgezondheidszorg, kinderopvang, welzijnswerk, algemeen maatschappelijk werk, thuiszorg of migranten zelforganisaties. Bureau Jeugdzorg biedt dus in feite een indirecte vorm van preventie aan, namelijk via intermediairen. In Utrecht gebeurt dit bijvoorbeeld via het Servicepunt Preventie (www.bjzutrecht.nl). Ze bieden verschillende trainingen op het gebied van opvoed- en opgroei ondersteuning, zoals 'signaleren, gespreksvoering, motiveren en verwijzen', 'pedagogisch adviseren', 'kortdurende hulpverlening aan jongeren', signaleren van kindermishandeling', 'beter omgaan met pubers' en 'Opvoeden Zo'. Bureau Jeugdzorg voert zelf geen preventieve interventies uit bij kinderen, jongeren of hun ouders.

\section{B8.3 Tweedelijns (geestelijke) gezondheidszorg}

Net als de eerstelijn is ook de tweedelijns GGZ primair gericht op zorg. Deze sector bestaat voornamelijk uit GGZ-instellingen $( \pm 54)$ en instellingen voor verslavingszorg $( \pm 15)$. Veel instellingen voor verslavingszorg zijn gefuseerd met een GGZ-instelling. Ook psychiatrische afdelingen van een ziekenhuis en vrijgevestigde psychologen en psychiaters behoren tot de tweedelijn.

De setting van een tweedelijns GGZ-instelling is in principe niet erg geschikt voor het aanbieden van preventieve interventies. Veel mensen met beginnende klachten voelen een drempel om zich te melden bij de poorten van een GGZ-instelling. Om die reden zijn de preventie-afdelingen van deze instellingen hun activiteiten steeds meer gaan aanbieden buiten de eigen instelling, in samenwerking met andere actoren in vooral de eerstelijn en de openbare gezondheidszorg.

Het aanbod van preventie door de preventie-afdelingen in de tweedelijns GGZ groeit de laatste jaren. De capaciteit van preventie in GGZ-instellingen is tussen 2000 en 2004 met ongeveer de helft toegenomen. In 2004 werd per GGZ-instelling en per verslavingszorginstelling gemiddeld $3 \%$ van de totale capaciteit ingezet voor preventie (Van de Lindt, 2005; Voordouw \& Schaeffer, 2005). Bij GGZ-instellingen betreft het aanbod voornamelijk selectieve en geïndiceerde preventie, terwijl de instellingen voor verslavingszorg juist erg actief zijn op het gebied van de universele preventie. GGZ-instellingen voeren ook universele preventie uit in de vorm van life-skills programma's, zoals het trainen van sociale vaardigheden.

GGZ-instellingen hebben in 2004 de meeste tijd en budget voor preventie besteed aan de volgende thema's: preventie van depressie bij (oudere) volwassenen, activiteiten voor kinderen van ouders met psychische problemen, preventie van arbeidsrelevante psychische problematiek en sociale psychiatrie (Voordouw \& Schaeffer, 2005). Op deze thema's werkt het GGZ-preventieveld in samenwerking met het Trimbos-instituut systematisch aan het ontwikkelen, evalueren en implementeren van gestandaardiseerde preventieprogramma's. 
GGZ-instellingen en instellingen voor verslavingszorg hebben in de afgelopen twintig jaar veel expertise opgebouwd op het terrein van systematische preventie van psychische stoornissen (Voordouw \& Schaeffer, 2005). Dat blijkt uit het feit dat ze betrokken zijn bij de meeste vormen van preventie zoals beschreven in hoofdstuk 3, 4 en 5. Om de het bereik van deze interventies te verhogen zijn ze steeds meer gaan samenwerken met actoren op andere deelterreinen. Daardoor komt deze kennis ook steeds meer beschikbaar buiten de tweedelijns GGZ. 


\section{BIJLAGE 9 GEBRUIKTE AFKORTINGEN}

\begin{tabular}{|c|c|}
\hline AMW & Algemeen maatschappelijk werk \\
\hline ARBO & Arbeidsomstandighedenwet \\
\hline ASI & Anxiety Sensitivity Index; vragenlijst voor het meten van angstklachten \\
\hline AUC & $\begin{array}{l}\text { 'Area under the curve'; maat voor het beoordelen van de effectiviteit van een } \\
\text { interventie op klachtenniveau }\end{array}$ \\
\hline AWBZ & Algemene wet bijzondere ziektekosten \\
\hline BDI & $\begin{array}{l}\text { Beck’s Depression Inventory; vragenlijst voor het meten van } \\
\text { depressiviteitsklachten }\end{array}$ \\
\hline CAS-code & $\begin{array}{l}\text { Classificatie voor Arbo en SV; Codering die door het UWV gebruikt wordt } \\
\text { om redenen voor arbeidsongeschiktheid te registreren. Dit is de door de } \\
\text { verzekeringsarts aangegeven belangrijkste diagnose van de ziekte }\end{array}$ \\
\hline CBS & Centraal bureau voor de statistiek \\
\hline CES-D & $\begin{array}{l}\text { Centre of Epidemiology Studies Depression scale; vragenlijst voor het meten van } \\
\text { depressiviteitsklachten }\end{array}$ \\
\hline CIDI & $\begin{array}{l}\text { Composite International Diagnostic Interview; meetinstrument om de } \\
\text { aanwezigheid van een psychische stoornis vast te stellen }\end{array}$ \\
\hline DALY & $\begin{array}{l}\text { Disability adjusted life years; maat voor het kwantificeren van de ziektelast (voor } \\
\text { een uitleg zie tekstblok 1.1) }\end{array}$ \\
\hline $\mathrm{DBC}$ & Diagnose-behandel combinatie \\
\hline DIS & $\begin{array}{l}\text { Diagnostic Interview Schedule; meetinstrument om } \\
\text { de aanwezigheid van een psychische stoornis vast te stellen }\end{array}$ \\
\hline DSM & $\begin{array}{l}\text { Diagnostic and Statistical Manual of Mental Disorders (IV en -IIIR); } \\
\text { classificatiesysteem voor het vaststellen van psychische stoornissen }\end{array}$ \\
\hline EDS & $\begin{array}{l}\text { Edinburgh Depression Scale; vragenlijst voor het } \\
\text { meten van depressiviteitsklachten }\end{array}$ \\
\hline GGD & Gemeentelijke gezondheidsdienst \\
\hline GGZ & Geestelijke gezondheidszorg \\
\hline ICD & $\begin{array}{l}\text { International Classification of Diseases (versie } 9 \text { of 10); classificatiesysteem } \\
\text { gebruikt in de (somatische) gezondheidszorg }\end{array}$ \\
\hline ICPC & $\begin{array}{l}\text { International Classification of Primary Care; classificatiesysteem gebruikt in de } \\
\text { eerstelijnszorg }\end{array}$ \\
\hline JGZ & Jeugdgezondheidszorg \\
\hline KEA & Kosteneffectiviteits analyse \\
\hline KOPP & Kinderen van ouders met psychische problemen \\
\hline KvZ & Kosten van ziekten \\
\hline Lasa & Longitudinal aging study Amsterdam \\
\hline Nemesis & Netherlands mental health survey and incidence study \\
\hline NIZW & Nederlands instituut voor zorg en welzijn \\
\hline NNT & Numbers-needed-to-be-treated (voor een uitleg zie tekstblok 2.3) \\
\hline QUALY & Quality adjusted life years: voor kwaliteit-van-leven-gecorrigeerd levensjaar \\
\hline RCT & $\begin{array}{l}\text { Randomised Clinical Trial; effectstudie waarin de proefpersonen willekeurig zijn } \\
\text { toegewezen aan de interventiegroep dan wel de controlegroep }\end{array}$ \\
\hline RIVM & Rijksinstituut voor Volksgezondheid en Milieu \\
\hline RR & Relatief risico (voor een uitleg zie tekstblok 2.3) \\
\hline RV & Risicoverschil (voor een uitleg zie tekstblok 2.3) \\
\hline SCAS & Spence Children’s Anxiety Scale; vragenlijst voor het meten van angstklachten \\
\hline SCL-A & $\begin{array}{l}\text { Symptom Check List-Angst; vragenlijst voor het meten van psychische klachten, } \\
\text { subschaal angstklachten }\end{array}$ \\
\hline SPV & Sociaal-psychiatrisch verpleegkundige \\
\hline
\end{tabular}


STAI State-Trait Anxiety Inventory, vragenlijst voor het meten van angstklachten UWV Uitvoering werknemersverzekeringen

VTV Volksgezondheid toekomt verkenningen

VWS Ministerie van Volksgezondheid, Welzijn en Sport

Wajong Wet arbeidsongeschiktheidvoorziening jong-gehandicapten

WAO Wet op de arbeidsongeschiktheidverzekering

WAZ Wet arbeidsongeschiktheidverzekering zelfstandigen

WCPV Wet collectieve preventie volksgezondheid

WIA Wet werk en inkomen naar arbeidsvermogen

WMO Wet maatschappelijke ondersteuning

ZonMw De Nederlandse organisatie voor gezondheidsonderzoek en zorginnovatie 